\title{
وقف النقود
}

\author{
حقيقته، وحكمه، وطرق وضوابط استثماره \\ "دراسة فقهية مقارنة"
}

\section{إعداد}

د. سعاد محمد عبد الجواد بلتاجي

الأستاذ المساعد بقسم الفقه المقارن

بكلية الاراسات الإسلامية والعربية للبنات بالإسكندرية

2016 - 1437 


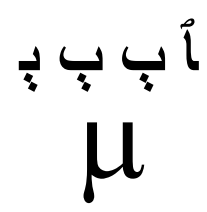

الْحَمد لله أول كل مقَّل ومبدأ كل سُؤال، لَه الْمَنْ والإفضضال على مـا أنعم به علينا من الرزق والمال، واستخلفنا فيه بالإنفاق والسعي الطيال

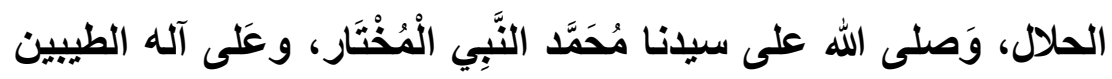
الأخيار، وَسلم تَسنْليمًا كثيرا.

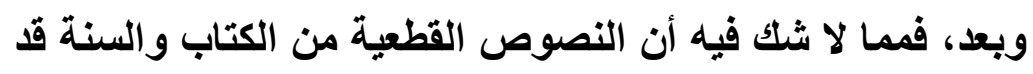

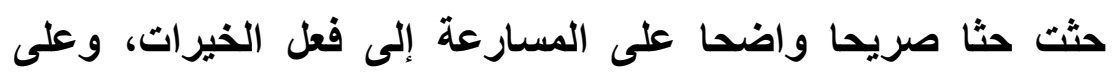

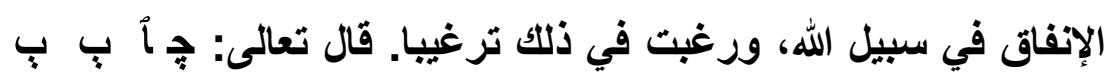

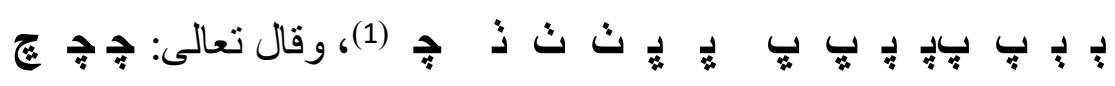

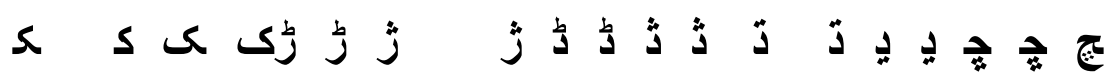

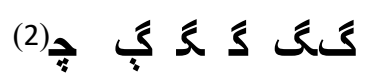

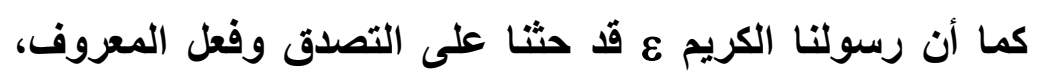

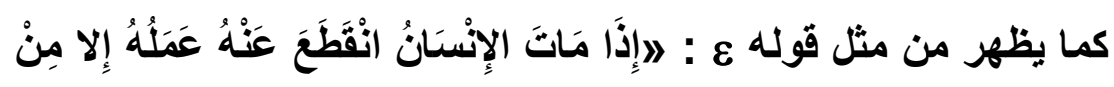

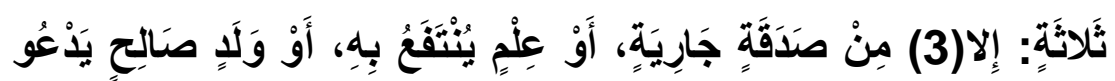

(4). لَّهُ

وقد فتحت الثريعة الإسلامية لفعل ذلك الخير أبو ابا وروافد كثيرة،

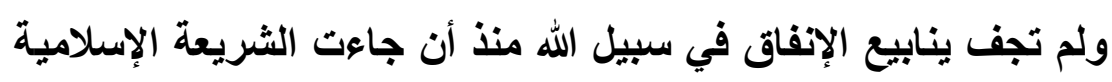

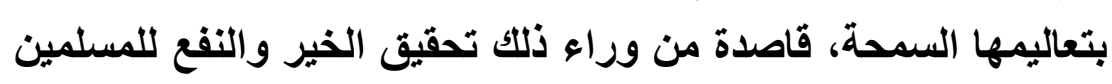
في أمر المعاش والمعاد؛ وذللك بتحصيل الثواب واءئ والنفع الأخروي

$$
\text { (2) سورة البقرة، الآية: الآية: بونج }
$$

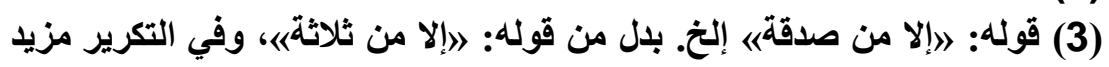

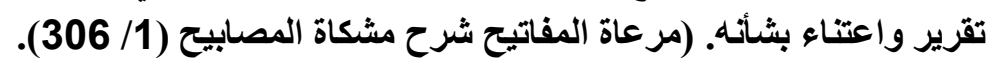

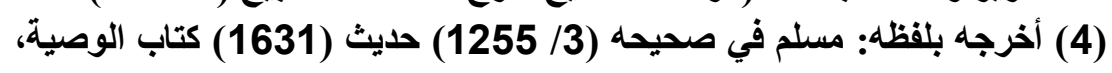
باب ما يلحق الإنسان من الثواب بعد وفاته، وأخرجه غيره. 
بالتقرب إلى الله عزو جل والفوز بجناته، وبسد حاجات المحتاجين، وعوز المعوزين، فشرعت وجوها كثيرة للإنفاق، منها ما هو إلزامي

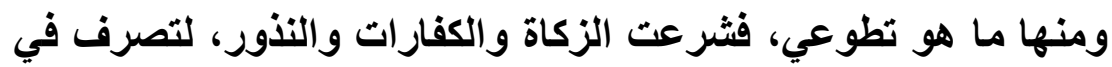
جهات ومصارف معينة، وشرعت الأوقاف والصدقات التطوعية لتكمل بقية حاجات المجتمع المسلم، والتي لم تستغرقها النفقات الإلزامية، وكان للأوقاف في الثريعة الإسلامية دورا مهما على مدار التاريخ الإسلامي، بل هو سمة من سمات المجتمع المسلم، ومن أبرز نظمه في في الإدي

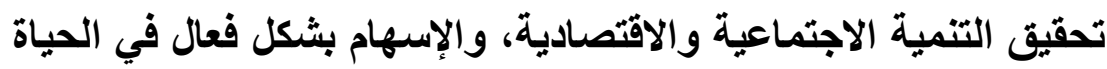

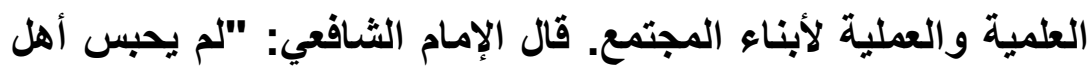

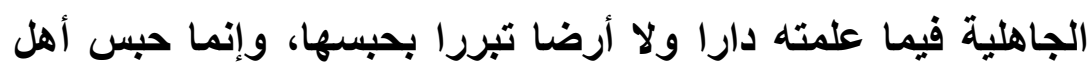

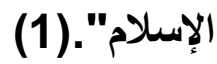

فكان - وما زال - الوقف في ظل الحضارة الإسلامية من أكبر المؤسسات التمويلية التي عرفها التاريخ، وذلك بعدم محدوديته و اتساع آفاق مجالاته، والقدرة على تطوير أساليب التعامل معله، وكل التل هذا يحقق للمجتمع المسلم التراحم والتوادّ بين أفراده على مَّز العصور بمختلف مستوياتها السياسية والاقتصادية والاجتماعية التي مرت بها الأمة الإسلامية خلال الأربعة عشر قرناً الماضية.(2)

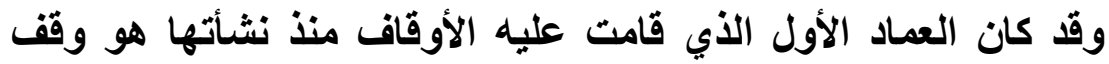

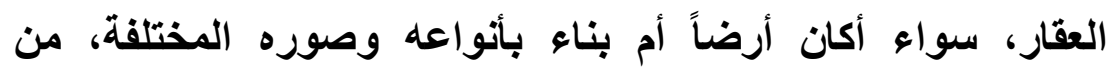

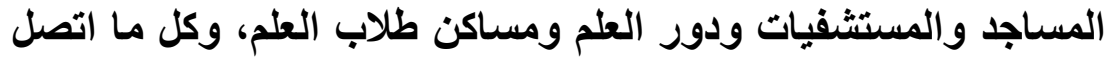
بذلك من طرق وجسور وقناطر.. إلخ، إضافة إلى وقف المنقولات التي التئ

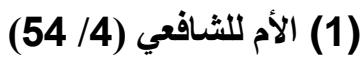

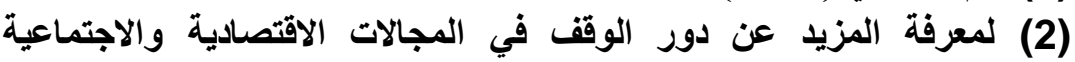

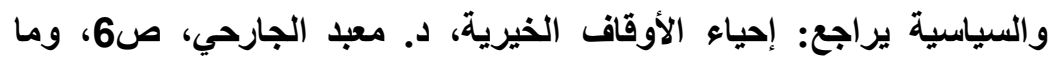
بعدها، الوقف ودوره في التنمية الاجتماعية، د. سليم هاني منصور صل دافيل 10 


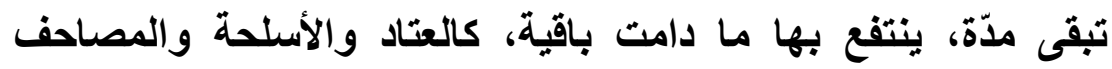

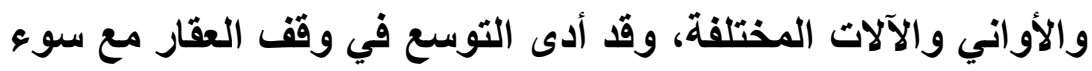
إدارته إلى حدوث بعض المشكلات في استثماره وتمويله وصياتته،

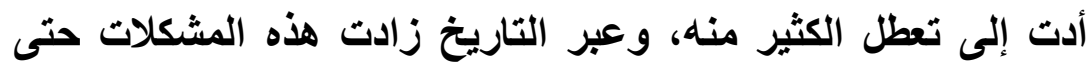

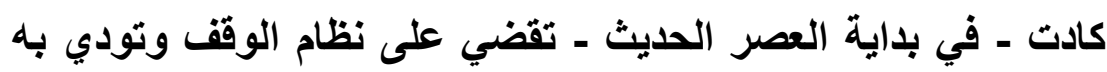

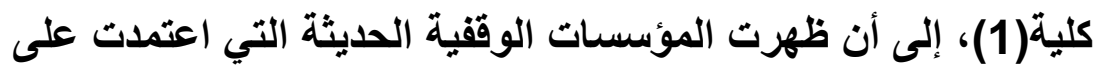

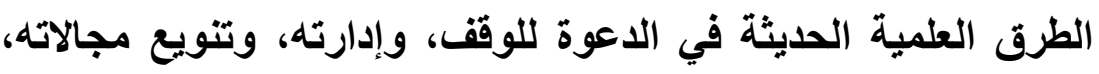
وإتباع الطرق الحديثة لتنميته واستثماره، فأعادت للوقف الهوت أهميته ودوره التاريخي العظيم.

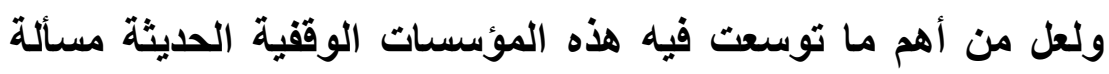

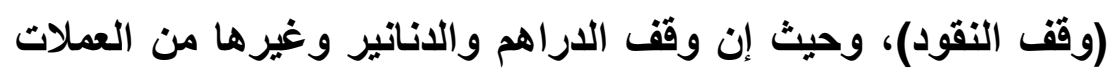

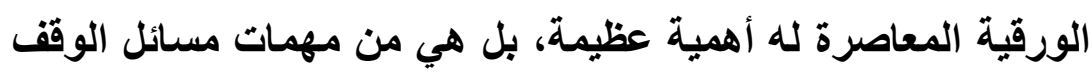

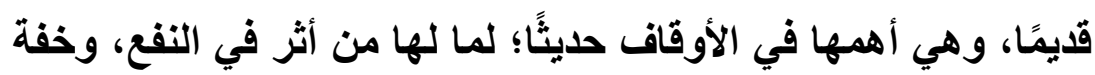

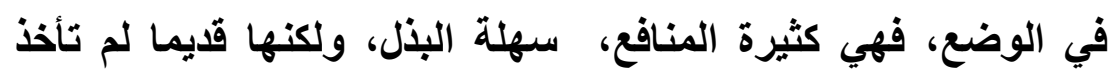
دورها التي أنيطت به؛ نظرا لوجود الخلاف في وقف النف النقود من جهة،

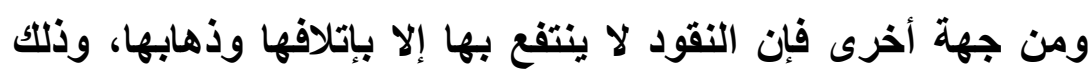

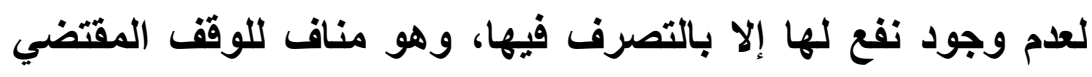

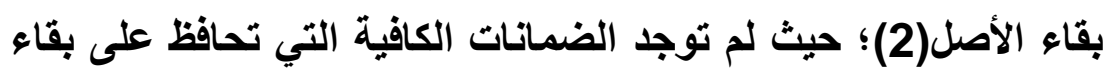
المال وعدم استهلاك عينه، ولم توجد أيضاً وسائل الاستثمارات

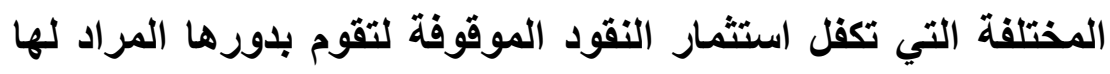
في وقفها، إلا أن الحال في هذا الزمن قد تغيرت بسبب تطور الوسائل

فقد حاول نظام الاستعمار الأوروبي لبلادنا الإسلامية أن يهام الأنظمة

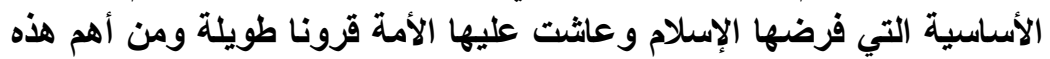

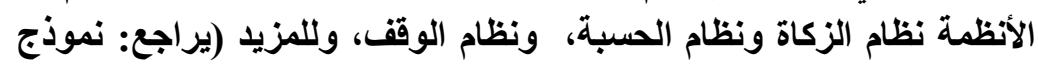

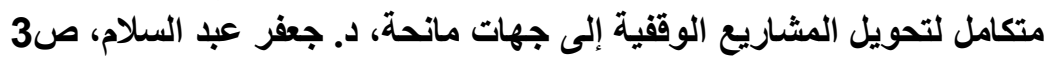


المختلفة في ضمان رد الأموال المقترضة، وفي سبيل استثمار النقود

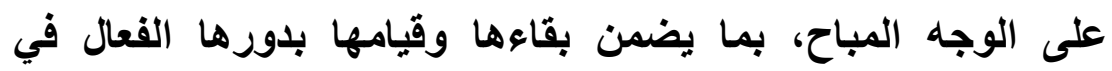

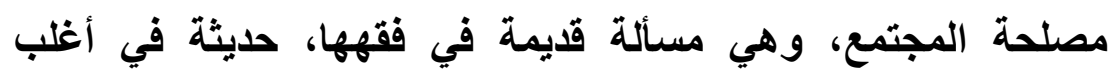

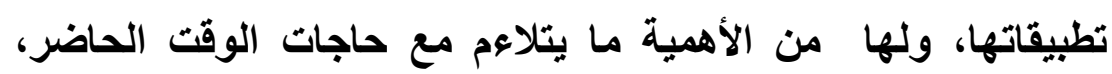

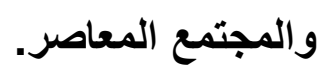

ولما كان وقف النقود من أهم الروافد والينابيع التي تسهم في قيام

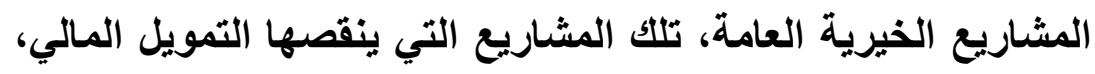

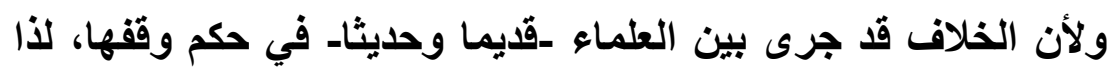

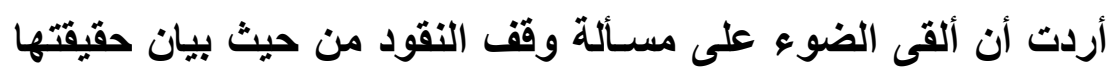

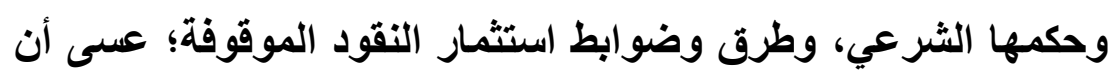
يكون ذلك سبيلا لإحياء هذا الرافد العظيم من روافو افل الإنفاق الإسلامي؛ ليحقق أهدافه المنشودة.

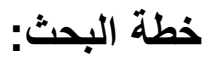
قسمت البحث إلى: مقدمة، وثلاثة مباحث، وخاتمة.

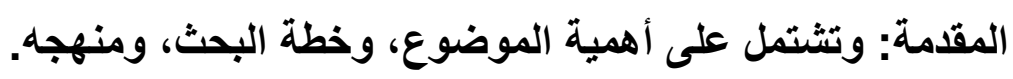
المبحث الأول: حقيقة وقف النقود.

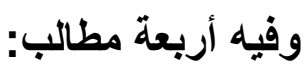

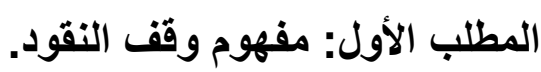

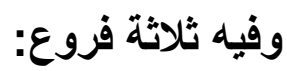
الفرع الأول: تعريف الوقف وشروطه وأركانه. الفرع الثاني: تعريف النقود. الفرع الثالث: تعريف وقف النقود. المطلب الثاني: نثأة النقود، وأثكالها المعاصرة.

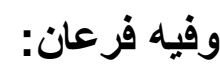

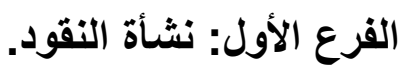
الفرع الثاني: الأثكال المعاصرة للنقود. المطلب الثالث: مزايا وقف النقود، ومخاطره. 
المطلب الرابع: أنواع وقف النقود. المبحث الثاني: الحكم الثرعي لوقف النقود، وبعض المسائل المتعلقة بوقفها.

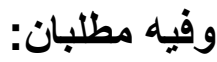
المطلب الأول: الحكم الشرعي لوقف النقود.

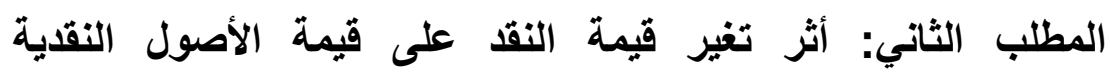

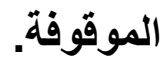

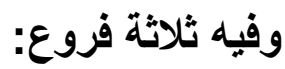
الفرع الأول: مصادر تحديد قيمة الأوراق النقدية. الفرع الثاني: أثر تغير قيمة النقد على قيمة الأصول النقدية الموقوفة الاولة

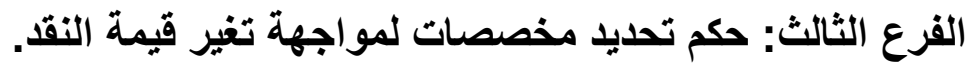
المبحث الثالث: طرق وضوابط استثمار النقود الموقوفة.

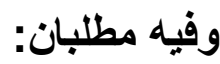
المطلب الأول: طرق استثمار النقود الموقوفة. المطلب الثاني: ضوابط استثمار النقود الموقوفة.

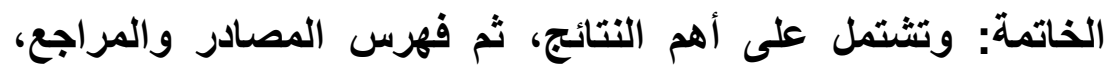

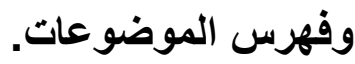
منهج البحث والدراسة: سلكت في هذا البحث المنهج التحليلي المقارن، حيث تتبعت الأحكام الفقهية ذات العلاقة بموضوع البحث، وقمت بدراستها، وتحليل آراء الفقهاء و المقارنة بينها، وكاتت طريقتي في البحث كالتالي: 1- درست مسائل هذا البحث على المذاهب الفقهية الثمانية، وكذاء

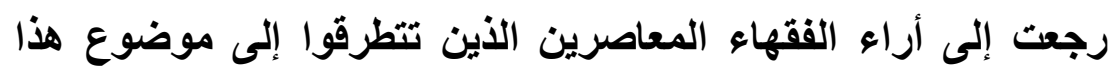

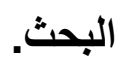
2- ذَكَرْتُ أدلة الفقهاء عقب ذكر آرائهم، ثُم قمت بمناقشتة هذه الأدلة،

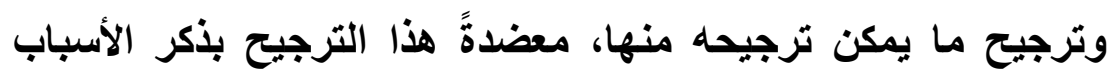

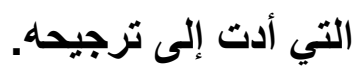


3- عزوت الآياتِ القرآنيةً المستثهََ بها في هذا البحث إلى سورها

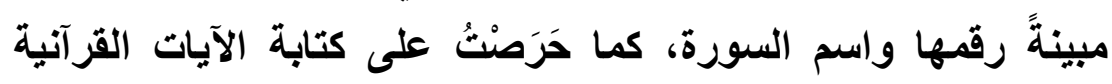

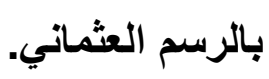

4 - خرَّت الأحاديث الواردة في ثنايا البحث، وبينت حكمها، فإذا كان

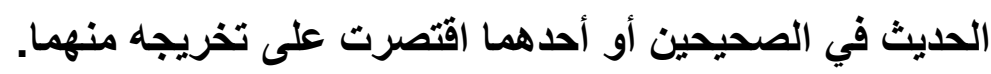

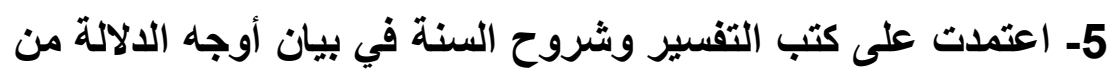

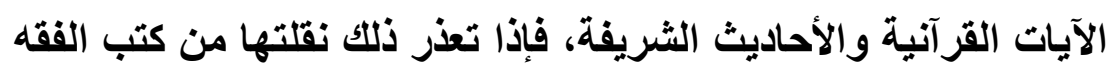

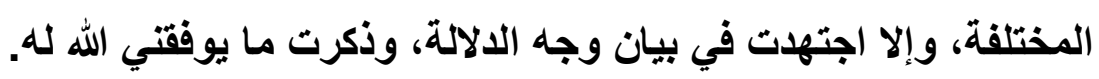

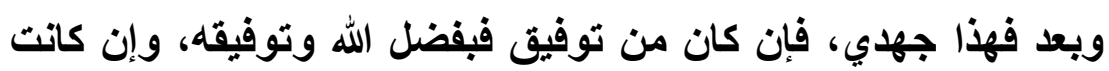
الأخرى فصسبي أني بشر مني الزيل والنسيان، واللة أسألُ العفو

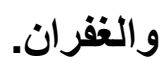

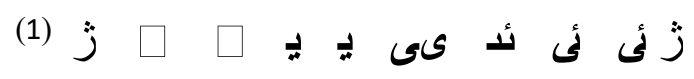




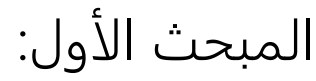

$$
\begin{aligned}
& \text { حقيقة وقف النقود. }
\end{aligned}
$$

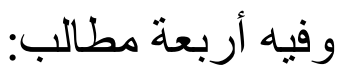

$$
\begin{aligned}
& \text { المطلب الأول: مفهوم وقف النقود. }
\end{aligned}
$$

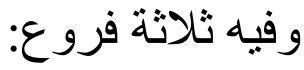

$$
\begin{aligned}
& \text { الفرع الأول: تعريف الوقف وشروطه تروطه وأركانه. }
\end{aligned}
$$

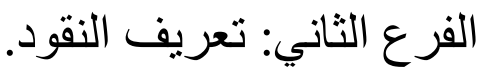

$$
\begin{aligned}
& \text { الفرع الثالث: تعريف وقف النقود. } \\
& \text { وفيه فر عان: } \\
& \text { الفرع الأول: نشأة النقود. }
\end{aligned}
$$




$$
\begin{aligned}
& \text { المطلب الأول } \\
& \text { مفهوم وقف النقود } \\
& \text { الفرع الأول: تعريف الوقف وشروطه وأركانه. } \\
& \text { تعريف الوقف: } \\
& \text { تعريف الوقف لغة: }
\end{aligned}
$$

الوقف في اللغة: الحبس(1)، مصدر وقف الثيء يقفه وحبسه،

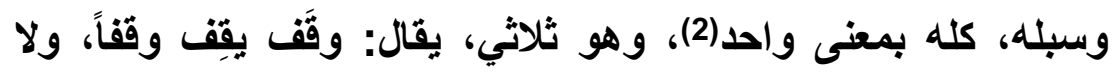

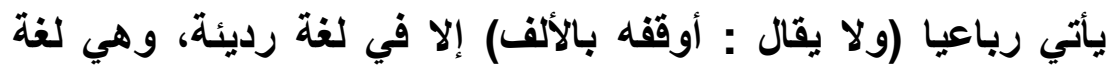

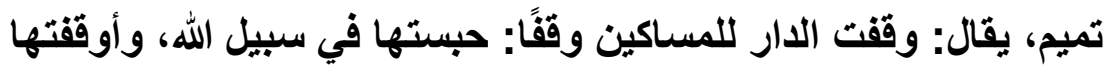
- بالألف - لغة رديئة(3)، ويُشتهر استعمال المصدر باسم المفعول، فيقال: هذه الدار وقف، أي موقوفة، ولهذا فإنه يثنى ويجمع عندئذ، ودئال

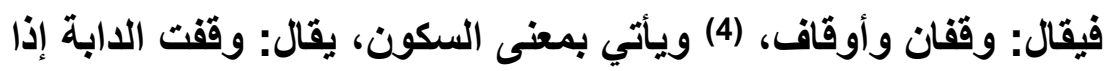

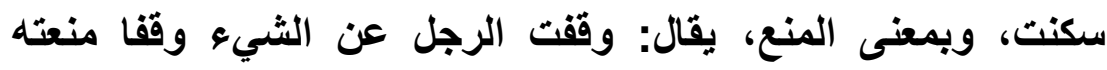

عنه. (5)

وسمي وقفاً؛ لأن العين موقوفة، وحبسًا؛ لأن العين محبوسة. (5)

تعريف الوقف اصطلاحا: ولان

(1) طلبة الطلبة في الاصطلاحات الفقهية (ص: 105)، أنيس الفقهاء في تعريفات

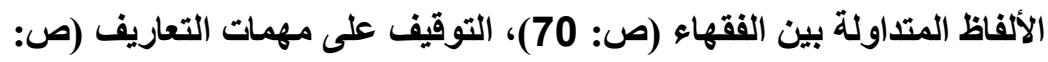

(2) المطلع على ألفاظ المقنع (ص: 344) (340)

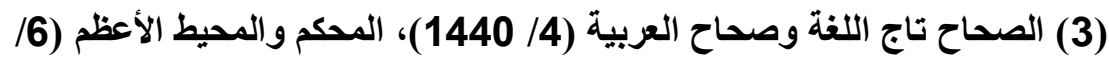

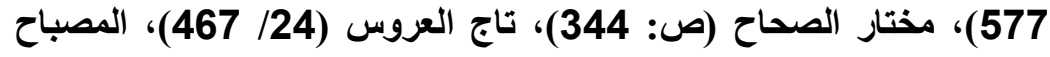

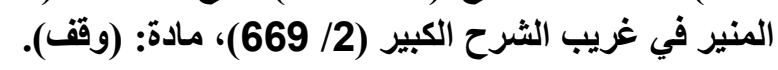
(4) المغرب في ترتيب المعرب (ص: 492)، المصباح المنير (292/ 669)، مادة)، مادة: 
اختلف الفقهاء في تعريف الوقف، تبعا لاختلافهم في حقيقته،

ونوع الملكية الثابتة به، واختلافهم في حكم الوقف من حيث اللزوم وعدمه(1)، واختلافهم في أثر الوقف على ملكية العين الموقوفة.

فتعددت تعريفاتهم للوقف على النحو التالي:

$$
\text { 1- عند الحنفية: }
$$

أ- عرَّف الإمام أبو حنيفة الوقف بأنه: حبس العين على حكم ملتك

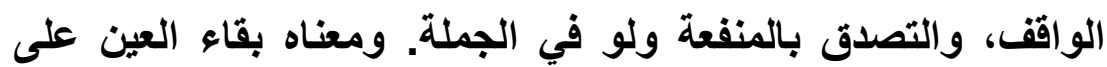

ملك الواقف، مع منعه من التصرف فيها.

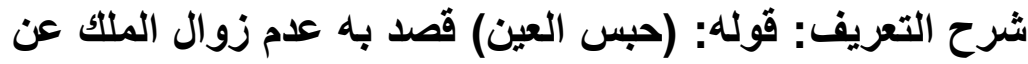
الواقف(3)، و:(قوله: على حكم ملك الواقف) قدر لفظ حكم ليكون تعريفا للوقف اللازم المتفق عليه، أما غير اللازم فإنها باق على على ملتك الواقف حقيقة عنده. (4) التونة

1) ففي المسألة الأولى: (لزوم الوقف وعدمه) ذهب الجمهور - المالكية،

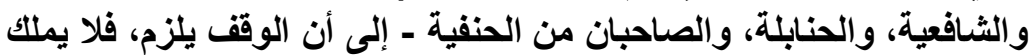

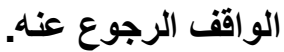

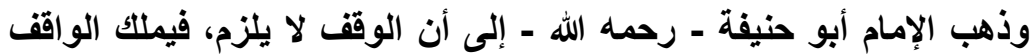

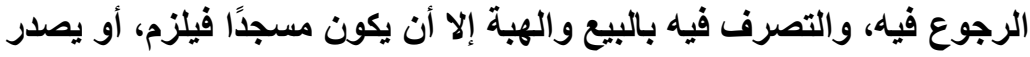

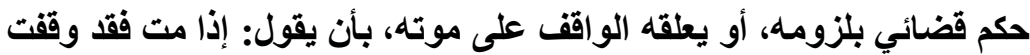

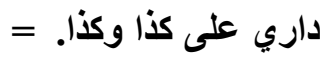

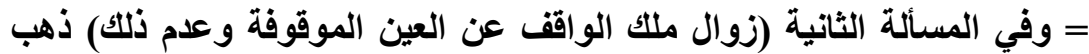

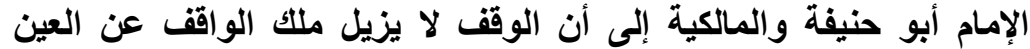

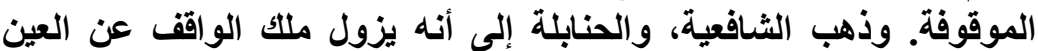

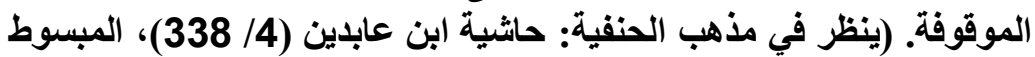

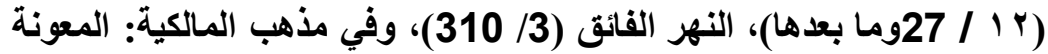

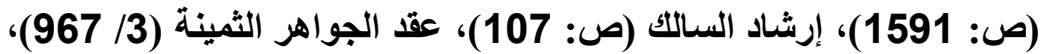

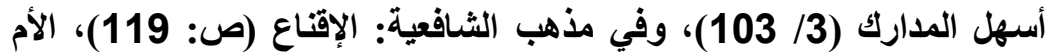

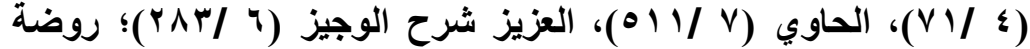

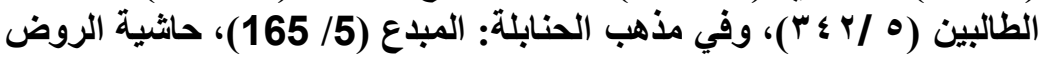

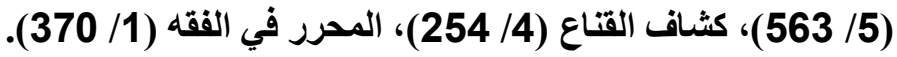

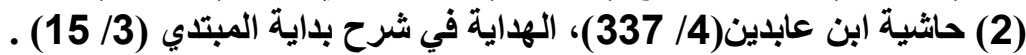

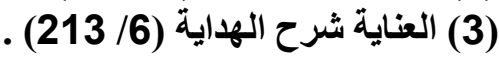

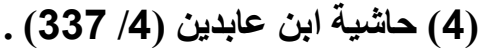


قوله: (والتصدق بالمنفعة) على الفقراء أو على جهة من سبيل

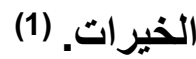

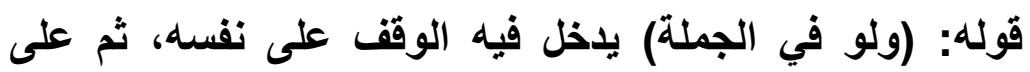

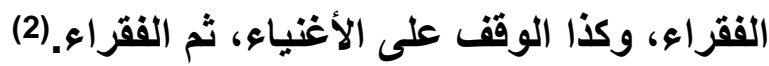

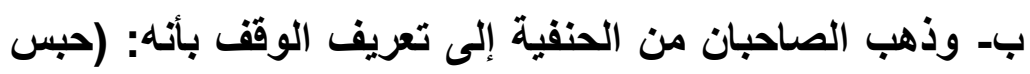

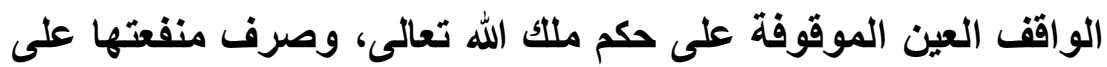

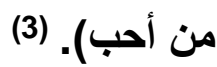

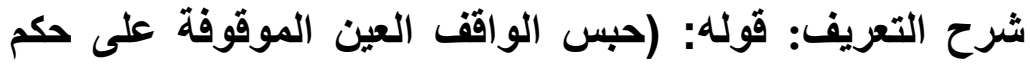

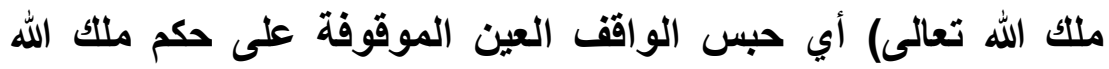

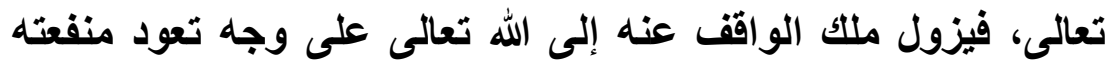

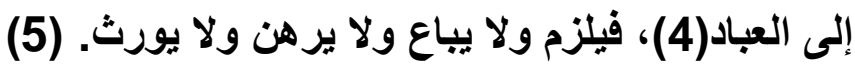

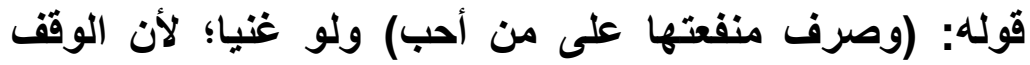

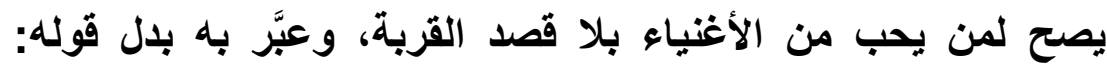

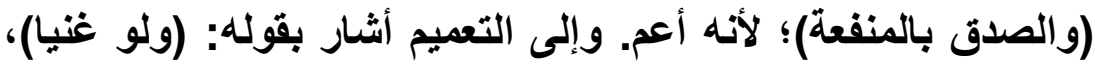

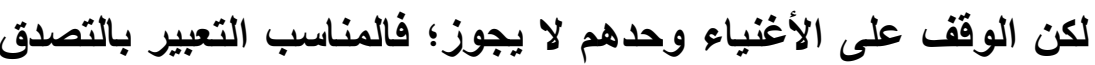

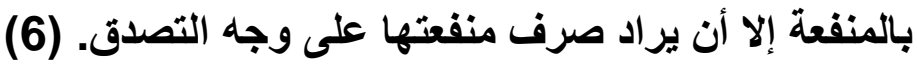
الفرق بين وجهة أبي حنيفة والصاحبين في التعريف: أن الوقف عند أبي حنيفة هو حبس العين على ملكه، عملا بمقتضى قولهي:

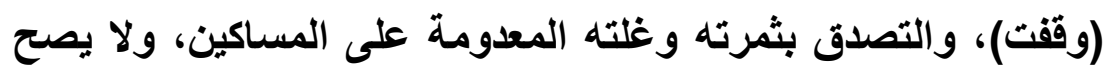

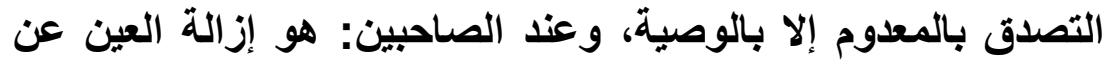

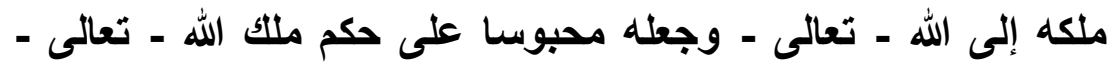
على وجه يصل نفعه إلى عباده، فوجب أن يخرج عن ملكه ويخلص الله

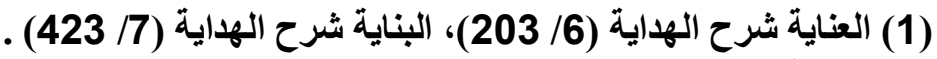

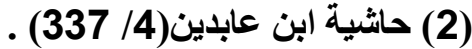

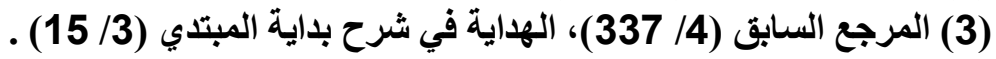

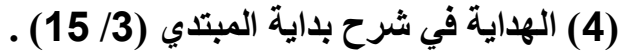

$$
\begin{aligned}
& \text { (5) الجوهرة النيرة (1/ 333)، البناية شرح الهاية (13/ 424)، درر الحكام شرح }
\end{aligned}
$$

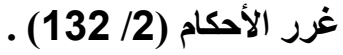

$$
\begin{aligned}
& \text { (6)حاثية (بن عابدين (4/ 339)، البحر الرائق (5/ 202) . }
\end{aligned}
$$


- تعالى - ويصير محررا عن التمليك ليستديم نفعه ويستمر وقفه

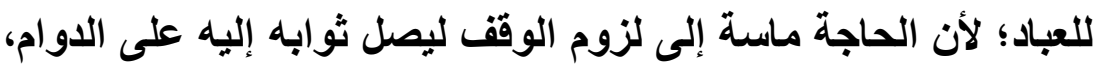

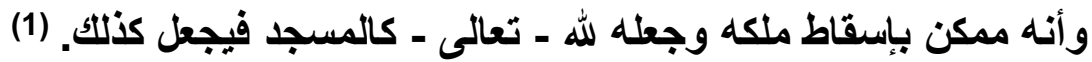

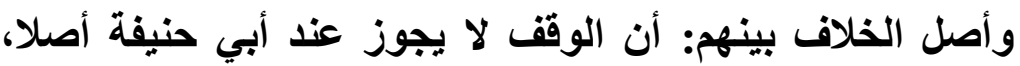

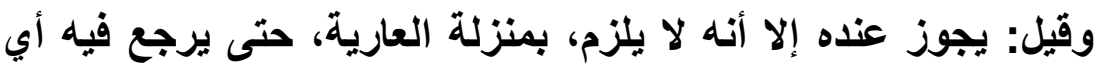

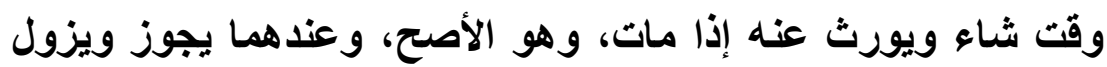

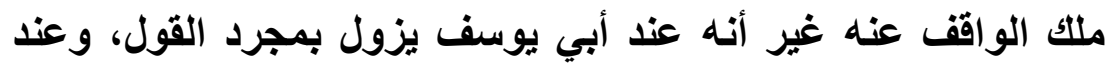

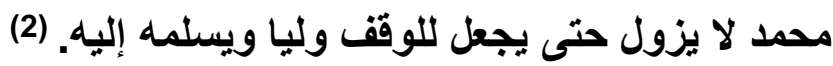
2- عند المالكية:

عرَّف ابن عرفة الوقف بتعريفين، أحدهما باعتباره مصدراً،

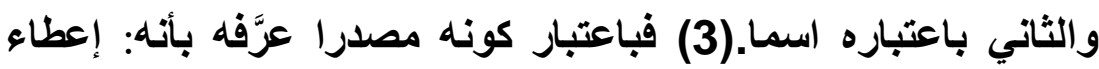

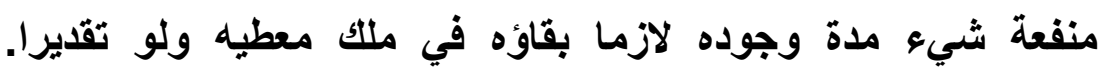

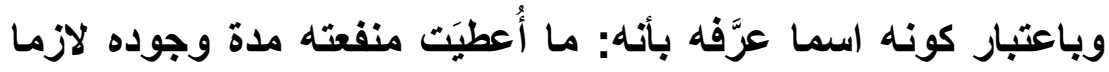

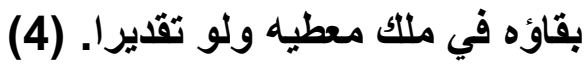

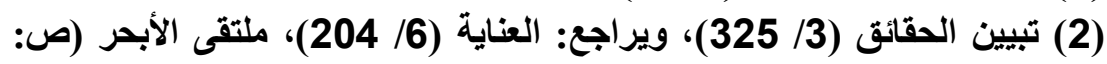

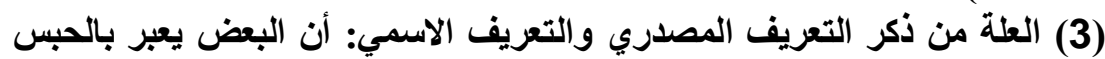

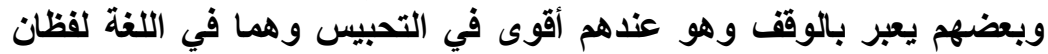

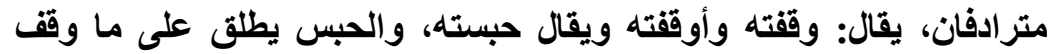

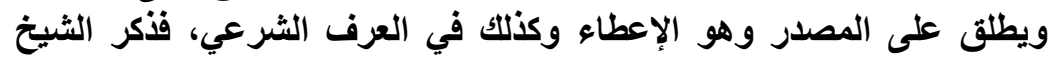

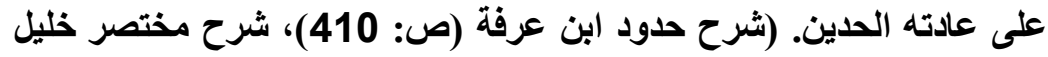

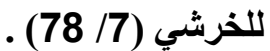
(4) شرح مختصر خليل للخرشي (78/7/ 78)، منح الجليل (8/ 108)، التاج والإكليل . (626/7) 


$$
\text { شرح التعريف: }
$$

شرح التعريف المصدري: (إعطاء منفعة شيع مدة وجوده لازما

بقاؤه في مللك معطيه ولو تقديرا).

قوله: (إعطاء) مناسب جنسية ولمون المعنى المصدري؛ لأنه من

مقولته، والتمليك والإعطاء مترادفان؛ لأنه قال في تعريف العطية: (تمليك متمول بغير عوض إنشاء) قال: فيلخل الحبس والهبة، فهو يدل

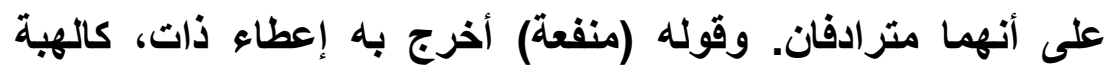

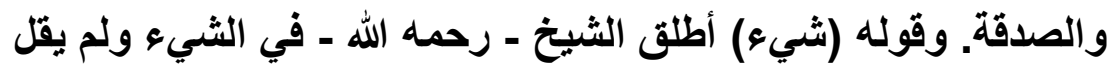

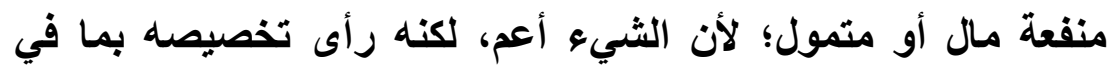

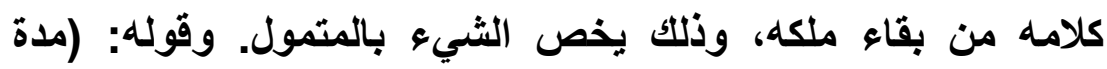

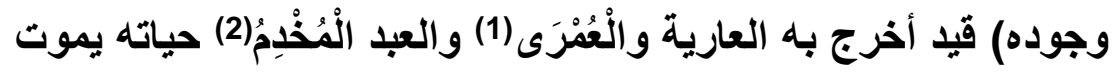

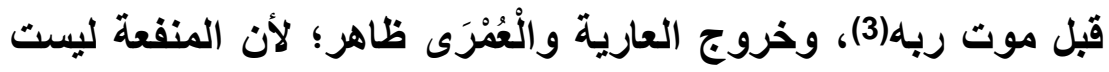

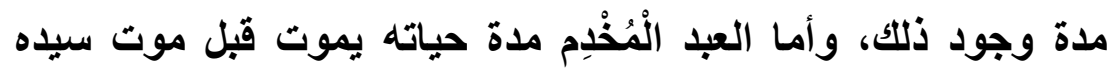
لعدم لزوم بقائه في ملك معطيه، ولجواز بيعه برضاه واه مع مع معطاه، فهو

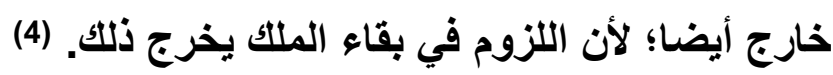
وقوله: (ولو تقديرا) حذفت منه كان، أي ولو كان اللزوم تقديرا

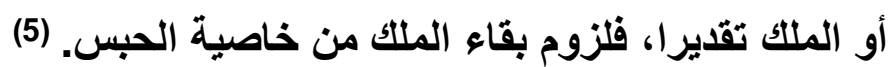

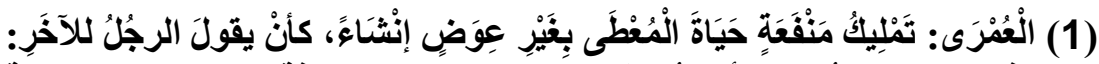

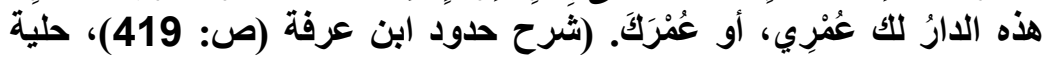

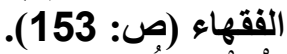

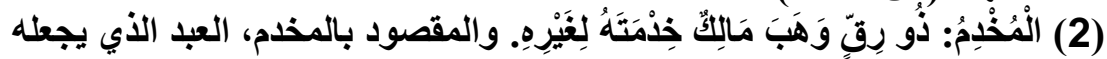

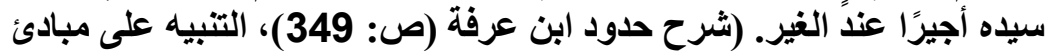

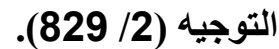

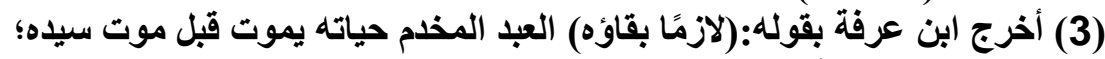

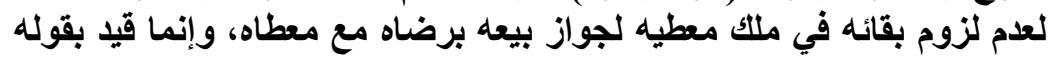

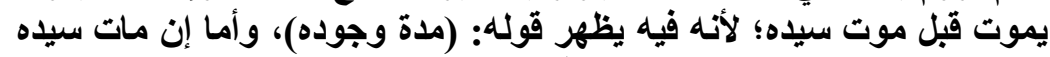

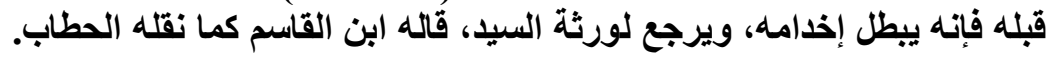

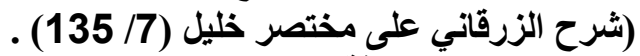
(4) شرح حدود ابن عرفة (ص: 4اني علئ 411، 412)، شرح مختصر خليل للخرشي (135) 
شرح التعريف الاسمي: "ما أعطيت منفعته...إلخ"، فبيانه كما

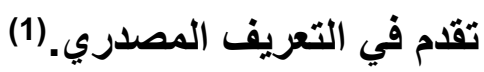

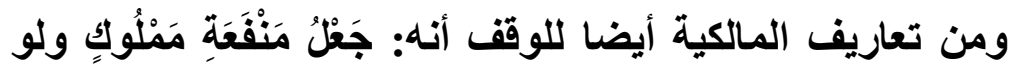

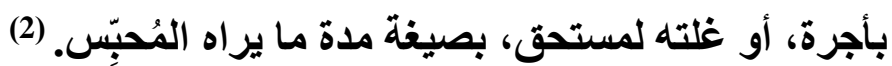

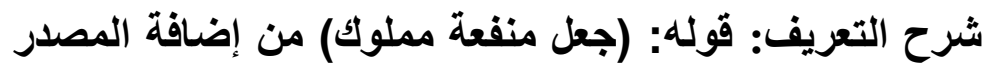

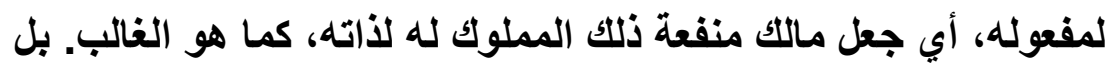

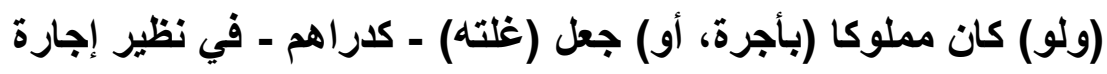

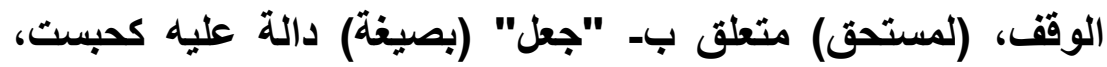

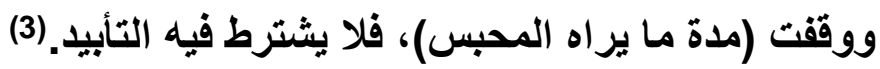

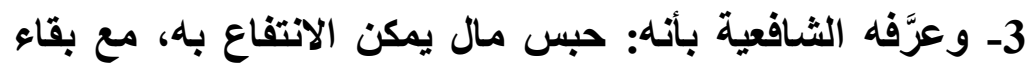

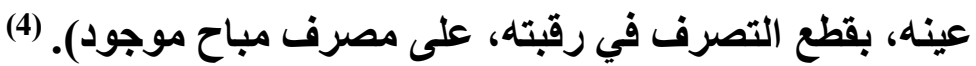
شرح التعريف: (حبس مال إلخ). والمراد بقوله: (مال): العين

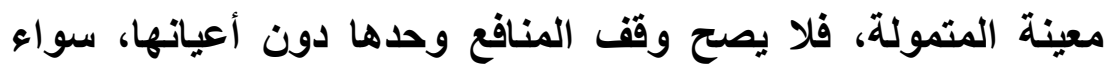

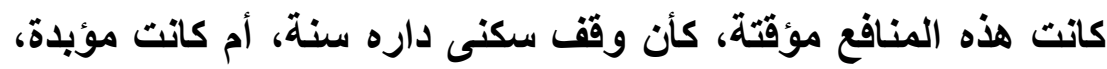

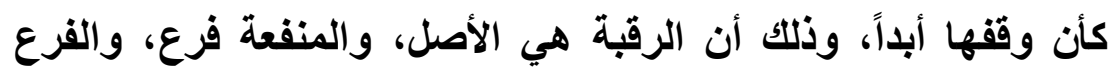

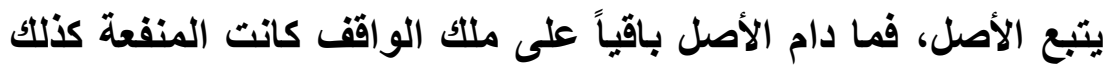
باقية على ملكه، فلا تنفصل وحدها بالوقف.

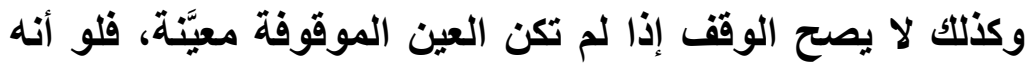

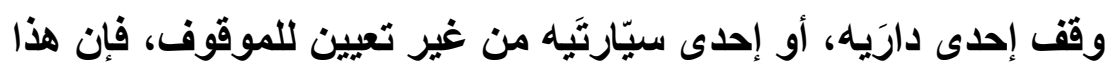

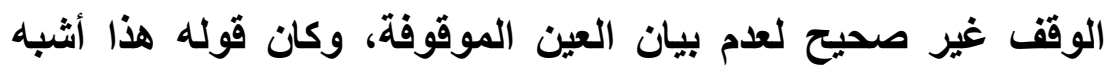

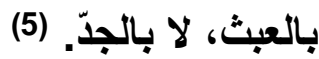

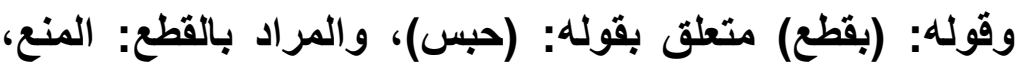

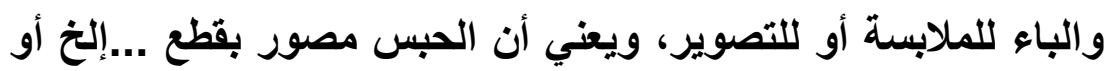

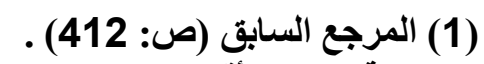

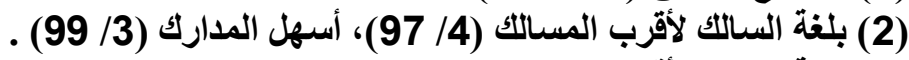

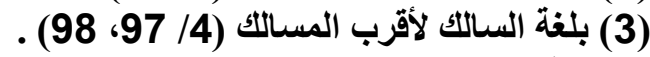

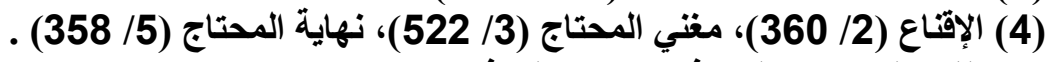

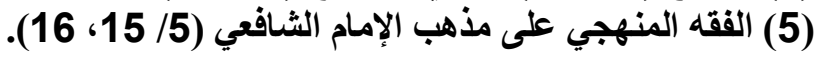


متلبس به، وقوله: (على مصرف) متعلق بحبس أيضا، وهو الموقوف

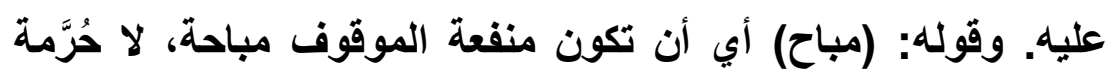

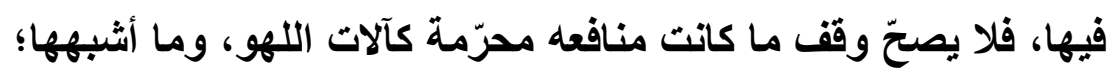

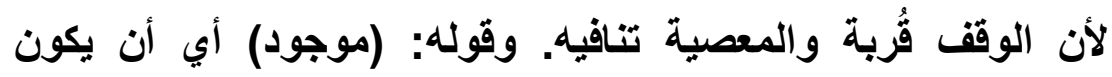

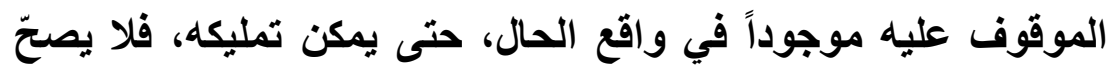

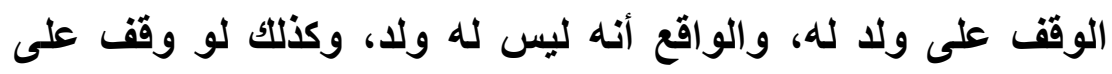

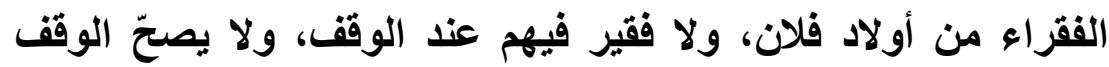

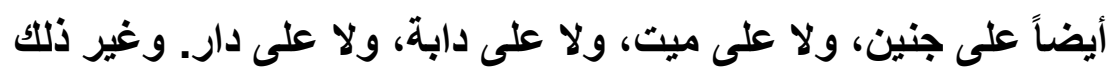

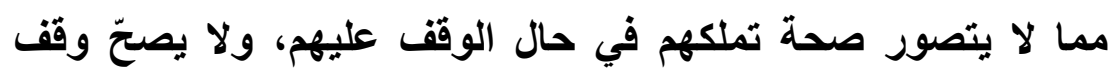
المصحف وكتب العلم الثرعية على غير مسلم؛ لعدم جواز تمليكه (إيّاها. (1)

4- وعرَّفه الحنابلة بأنه: (تحبيس مالك مطلق التصرف مالَه

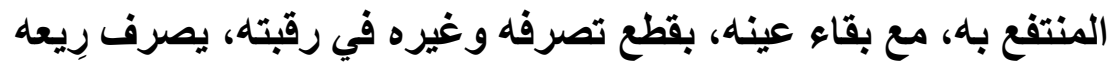

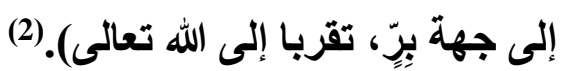
شرح التعريف: قوله: (تحبيس) معنى تحبيس الأصل: إمساك

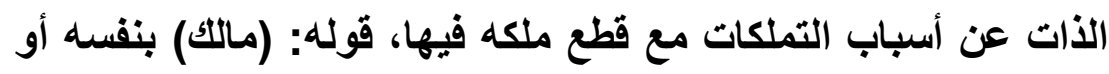
وكيله، (مطلق التصرف)، وهو المكلف الحر الرشيد، (ماله المنتفع به الهيه

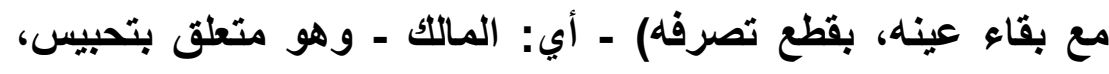

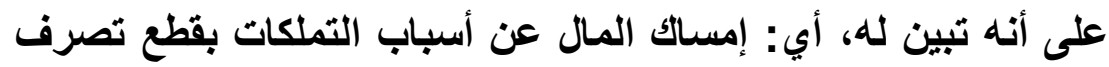

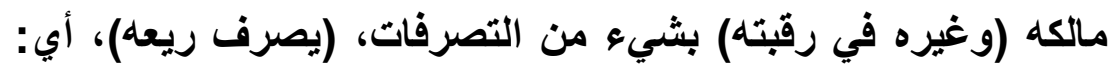

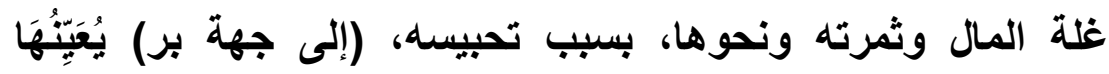

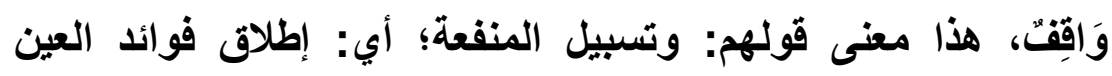

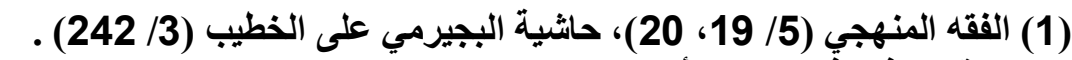

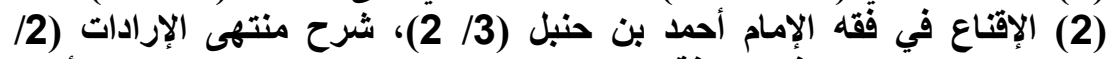

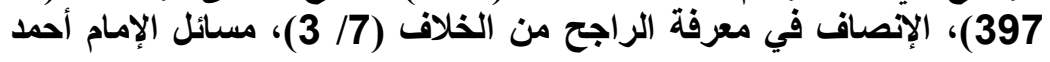

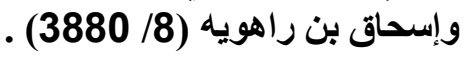


الموقوفة، من غلة وثمرة وغيرها؛ للجهة المعينة، (تقربا إلى الله

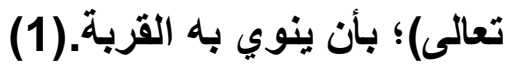
وعَرَّف ابن قدامة الوقف بأنه: باتهبه بتهبيس الأصل و تسبيل المنفعة" (2) - (2). شرح التعريف: قوله: (تحبيس الأصل) أي إمساك الذات عن من مات

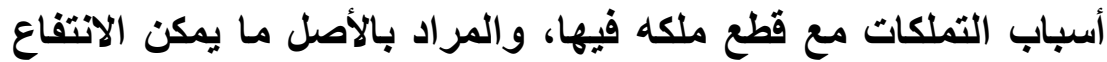
به مع بقاء عينه، وقوله: (وتسبيل المنفعة) أي إطلاق فوائد العين الموقوفة من غلة وثمرة وغيرها للجهة وفية المعينة(3).

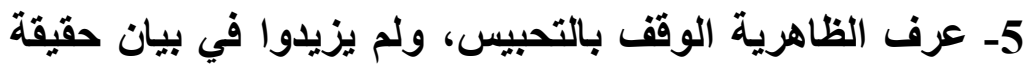

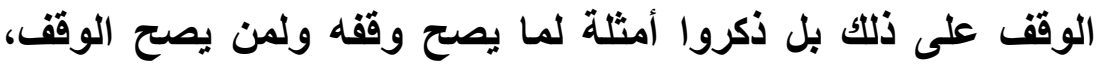
جاء في المحلى بالآثار:" والتحبيس - وهو الوقف - جائز في الأصول من الدور والأرضين بما فيها من الغراس والبناء إن كاتت فيها، وفي

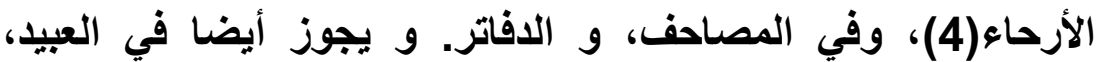

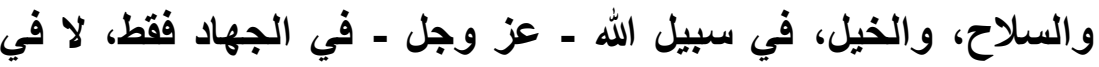
غير ذلك - ولا يجوز في شيء غير ما ذكرنا أصلا، ولا في بناء دون

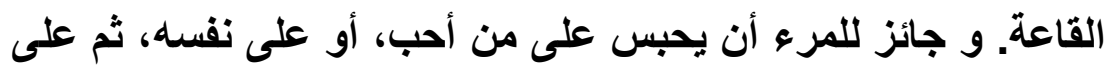

من شاء. (5)

6- وعرفه الإباضية بأنه: حبس الموقوف والتصدق بالمنفعة. (5)

(1) مطالب أولي النهى (4/ 270، 271)، 271)، شرح منتهى الإرادات (2/ 397)، كثاف القناع (4/ 240، 241 241 ) . (2) الثرح الكبير على متن المقتع (253/ (241/ 191)، الروض المربع شرح زاد المستقع (172)

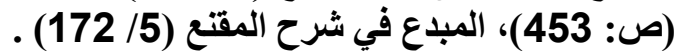
(3) كثاف القناع عن متن الإقناع (4/ 241)، الروض المربع (5) (172) شرح زاد المستقتع

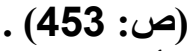

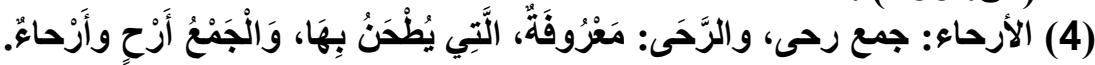

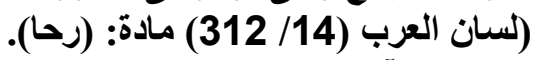

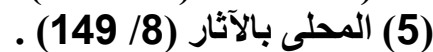
(6) شرح النيل للقطب أطفيش (12) (12 (454). 
وعرفوه أيضا بقولهم: الحبس وقف مال يمكن الاتتفاع به بَقَاءَ

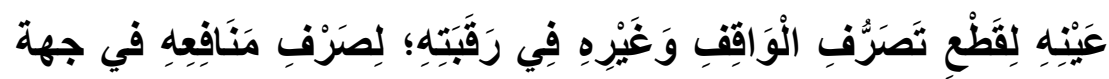

خير؛ تقربا إلى الله تعالى. (1)

ولم أقف على شرح لهذا التعريف عند الإباضية، لكنه قريب مما

ذكره الثافعية في تعريفهم، فيحال عليه.

7- وعرَّفه الزيدية بأنه: حبس مخصوص على على وجه مخصوص

بنية القربة. (2)

وقد بيَّن الإمام الثوكاني في تعليقاته القيود الواردة على هذا

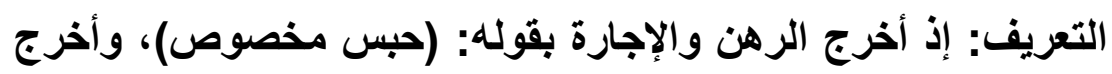

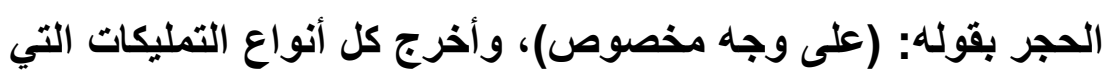

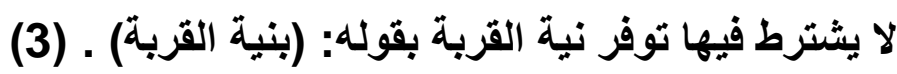

وقد اعترض على هذا التعريف بإغفاله للطرف الذي يقع منه

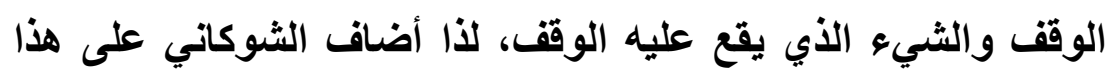

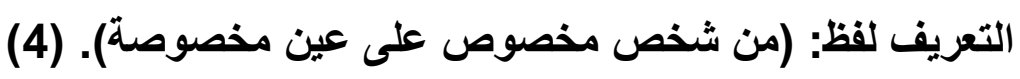


8- تعريف الوقف عند الإمامية:

أـ عرَّفه المحقق المحلي بأنه: عقد ثمرته تحبيس الأصل وإعطاء

(1) المنفعة.

شرح التعريف: هذا تعرف للوقف ببض خواصه تبعا للحديث

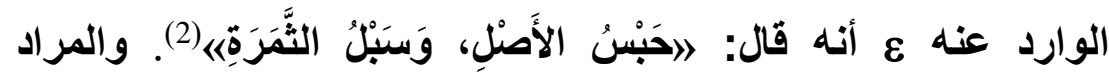
بتحبيس الأصل: المنع من التصرف فيه تصرفا ناقلا لملكه، وبتسبيل الثمرة: إباحتها للجهة الموقوف عليها، بحيث يتصرف فيها كيف شاء

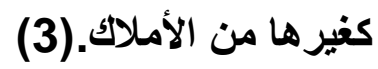

بـ وعُرِّفَ الوقف أيضا عند الإمامية بأنه: الصدقة الجارية. .

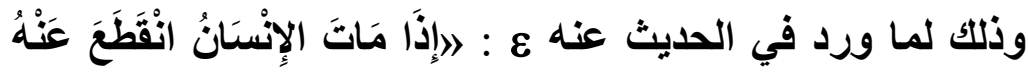

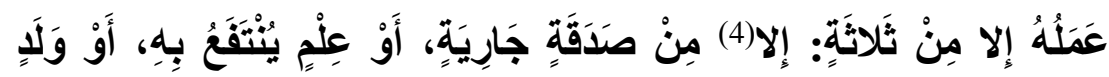

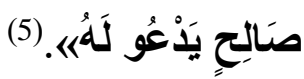

(1) شرائع الإسلام للحلى(442/2)، جواهر الكلام 2/28، الينابيع الفقهية

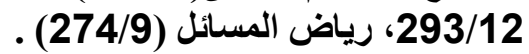

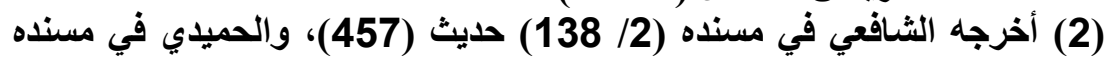

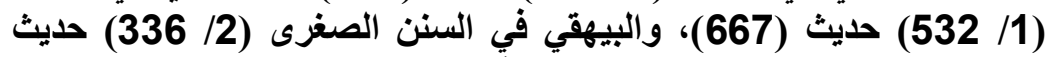

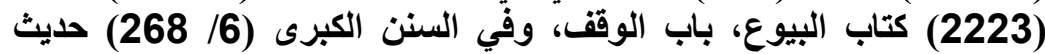
(11904، 11905) كتاب الوقف، باب وقفت المشاع، وقال ابن الملقن في البلر المنير (2/7 (99): هذا الحديث صحيح.

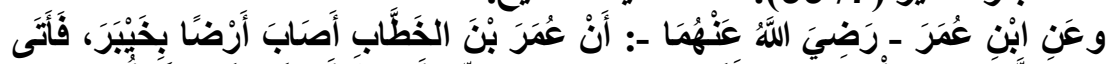

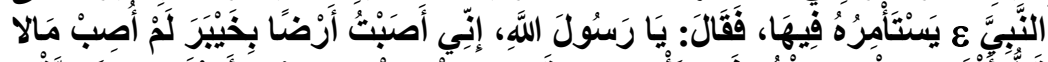

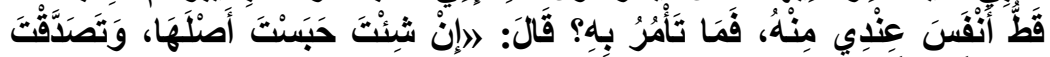

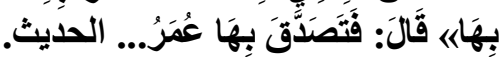

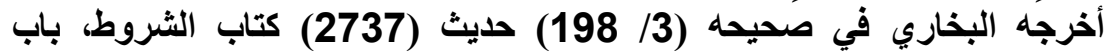

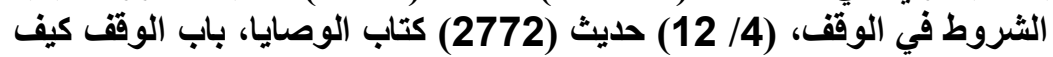

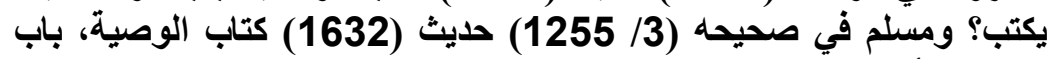
الوقف، وأخرجه فير هما.

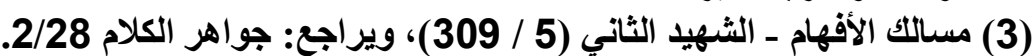

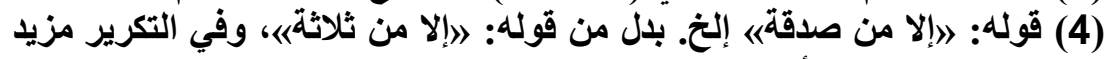

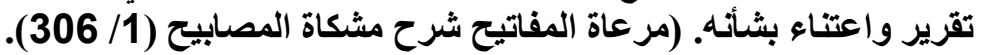
(5) (5بق تخريجه في المقدمة. 
قال العلماء: المراد بالصدقة الجارية: الوقف. وهو تعريف ببعض

$$
\text { الخواص أيضا. (1) }
$$

بعد عرض تعاريف الفقهاء على اختلاف المذاهب يتبين أن هناك نقاط التقاء واختلاف بين الفقهاء في مسألة الوقف، ويمكن حصرها إجمالا فيما يلي:

1- أن الققهاء ـ عدا الحنفية ـ متفقون على أن الوقف باب من أبواب التكافل في الإسلام، وأنه يخرج الثيء الموقوف من تصرف

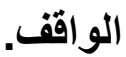

2- أن في هذه التعاريف قدرا مشتركا، وهو أن الوقف محبوس عينه، ومسبل ثمرته ونفعه لمن عينه الواقف ابتغاء مرضاة الله تعالى، أو نفع من يريد نفعه من قريب أو بعيد ولو لمن لم تظهر فيه وجه

القربة، كالوقف على الأغنياء، ما لم يكن في ذلك معصية لله

تعالى.)

(1) مسالك الأفهام - الثهيد الثاني (5 / 309)، تذكرة الفقهاء (124/226/2) (25/2)، الحدائق

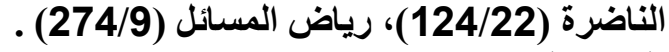

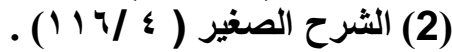

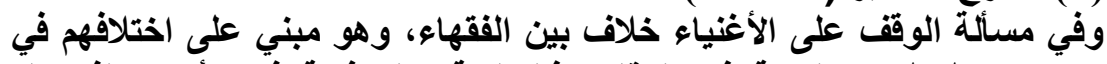

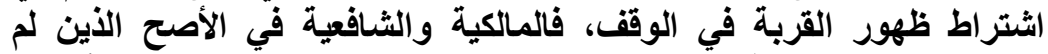

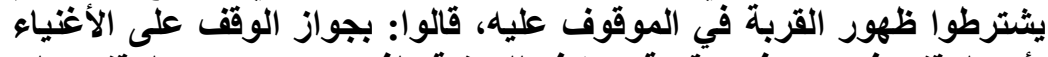

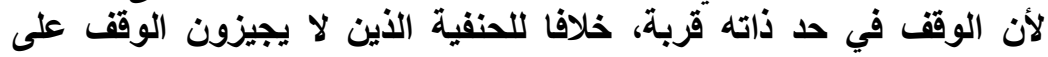

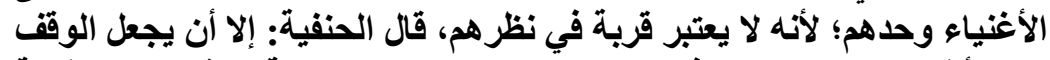

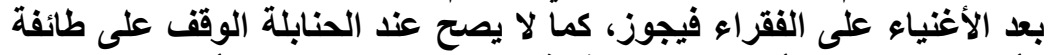

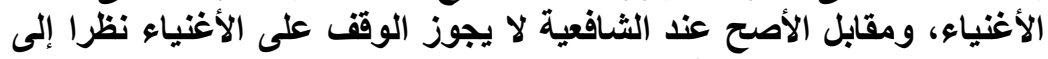
اشتراط ظهور قصد القربة يراجع: (الاختيار لتعليل المختار (3/ 46)، البحر الألئ 
3- أن الفقهاء اختلفوا في أمور كثيرة من مسائل الوقف، منها:

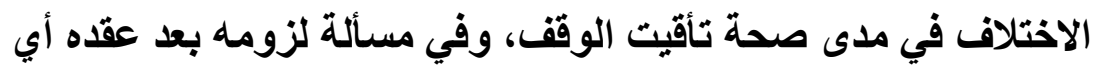
إمكانية رجوع الواقف عن وقفه، ومسألة خروج الوقف من ملك

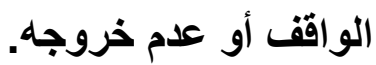

ولعل التعريف الراجح من هذه التعاريف هو تعريف ابن قدامة الوقف بأنه: "تحبيس الأصل و تسبيل المنفعة"؛ لما يلي:

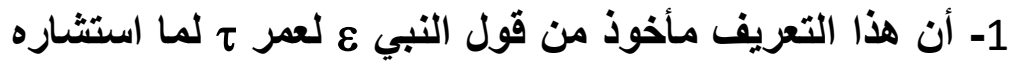

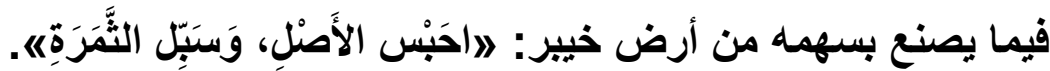

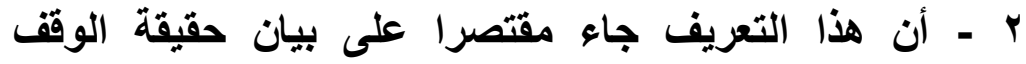

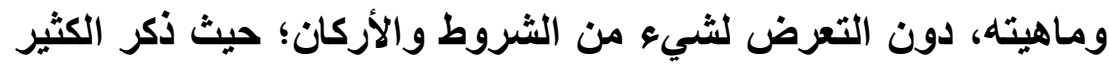
من الثروط والأركان في تعاريف أخرى فجاعت مطولة، و والثأن في التعاريف الإيجاز مع تمام المغنى. وتعريف الوقف بأنه: "تحبيس الأصل وتسبيل المنفعة"(1) رجحه الاكتور نزيه حماد، وعلل ترجيحه بأنه: يرجع إلى أن هذا التعريف فيه

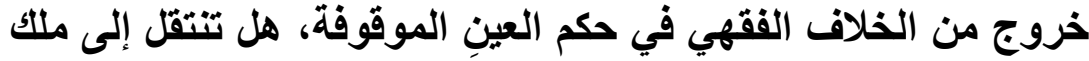
الموقوف عليه أم إلى ملك الله تعالى أم تبقى على ملك الت الو اقفى

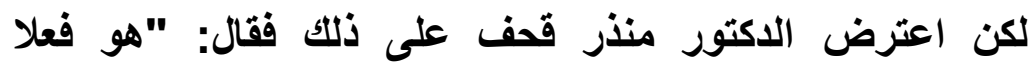
يتخلص من الاختلاف حول ملكية الموقوف، لكن لا يتخلص من الخلاف حول جواز وقف المنفعة ممن يملكها ولو بأجرة".

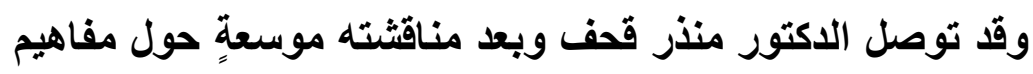
الوقف التي تحدث عنها الفقهاء القدامى وقسم من الفقهاء المعاصرين وبعض قوانين الوقف في الد ول العربية إلى التعريف الآتي:

الرائق (5/ 216)، الثرح الصغير ( ؛ /517/1)، الثرح الكبير للثيخ الاردير

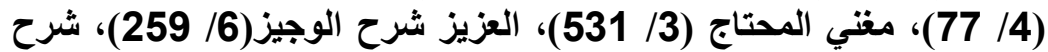

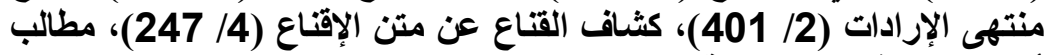

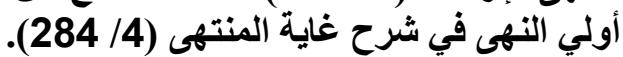
(1) معجم المصطلحات الاقتصادية في لغة الفقهاء، د. نزيه حماد ص353. 
(الوقُف هو حبس مؤبد أو مؤقّت لمالِ، للانتفاع المتكرر به أو

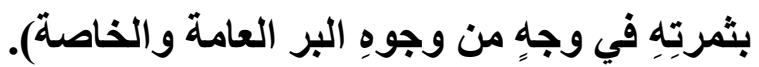

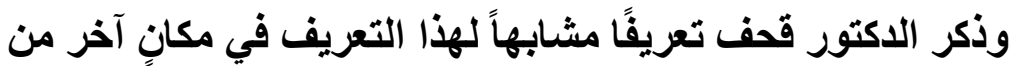

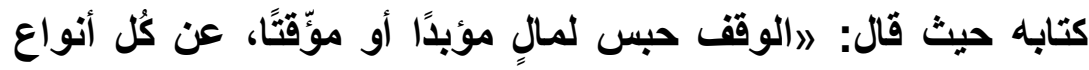

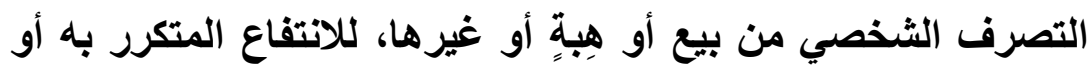

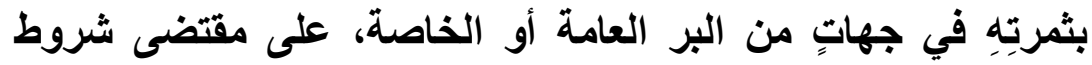

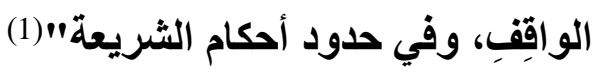

وعلَّق الاكتور منذر قحف على تعريفه، فذكر عدة أمور، منها:

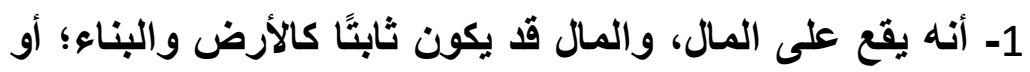

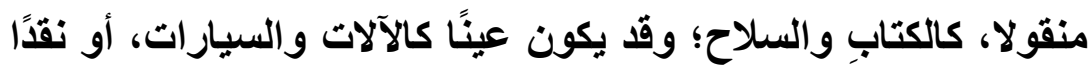

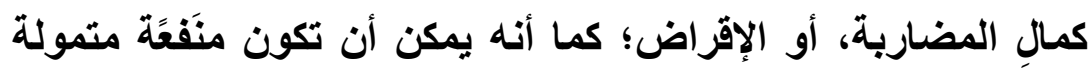

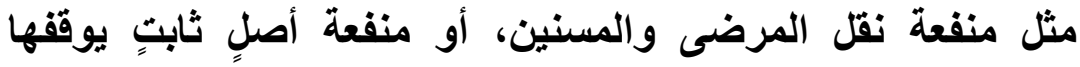
المستأجر باعتبار مالكها، نحو حق الطريق أو منفعة مصلَّى الأعياد

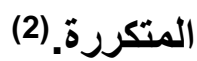
وإن الوقف يرِد على عينٍ أو منفعةٍ أو حق مالبي متقوم، لأن كل

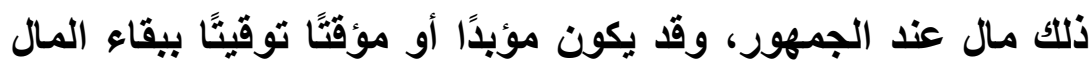
الموقوف أو بشرط الواقف، وقد ذكر الاكتور قدف أنه ضَّمَّن تعريفه

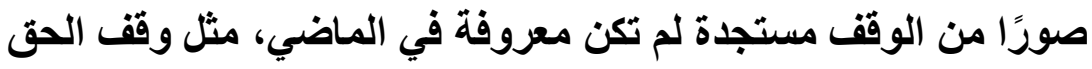

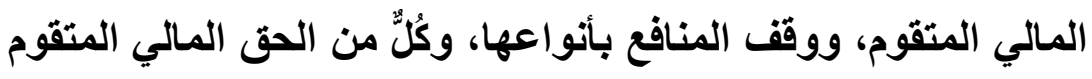

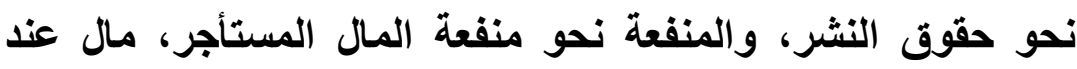
الجمهور بالنسبة للمنفعة، أو مال حسب الفتاوى الجماعية المعاصرة

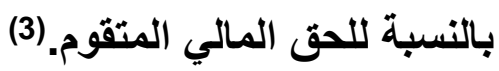

(1) قضايا فقهية معاصرة في الأوقاف الإسلامية، منذر قدف ص21.

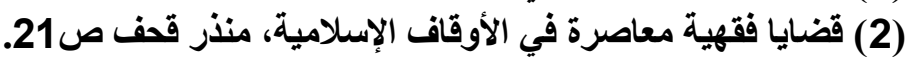

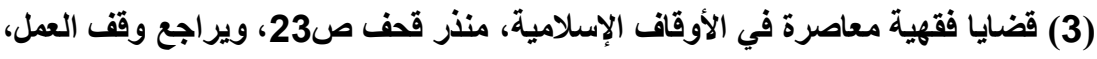

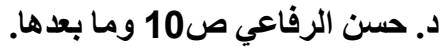


أركان الوقف: للوقف أربعة أركان، لا يتحقق وجوده إلا بها،

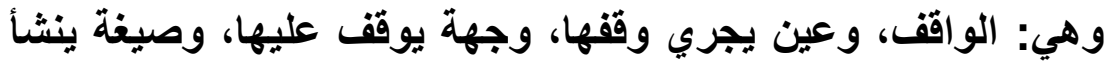
بها، وهذا عند المالكية(1)، والثافعية(2)، والحنابلة(3). وأما ركنه وفئه عند الحنفية فينحصر في: الصيغة (4) الصائ فالواقف هو المالك للأت أو المنفعة. و الموقوف هو ما ملك من ذات أو منفعة. و الموقوف عليه هو المستحق لصرف المنافع عليه. وصيغة الوقف: (صيغة) صريحة (بـ وققت أو حبست أو سبلت،

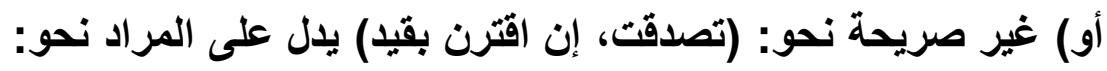
لا يباع، ولا يوهب، أو تصدقت به على بني فلان أنس طائفة بعد طائفة، أو أو عقبهم ونسلهم. (5) ولاعب، أل وسبب الخلاف بين الحنفية والجمهور: أن الحنفية يرون أن الركن

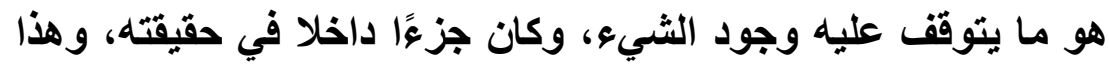

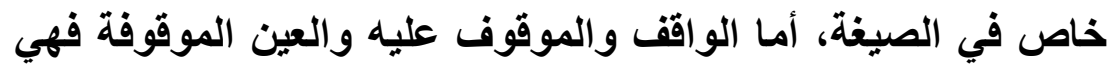
من لوازم العقد، وليست جزءًا من حقيقة العقد، وإن كان يتوقف عليها واليها

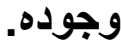

بينما الجمهور يرون أن الركن: ما توقف عليه وجود الثيء

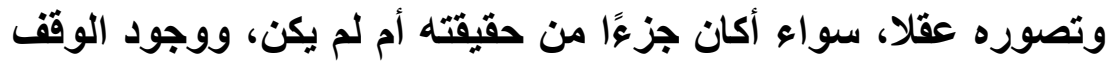

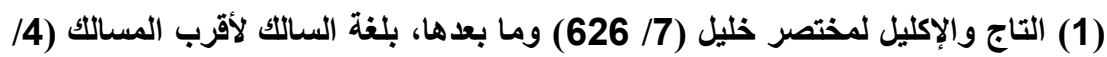

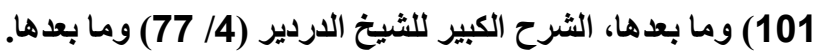

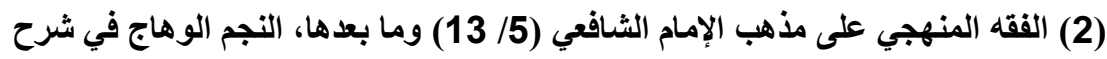

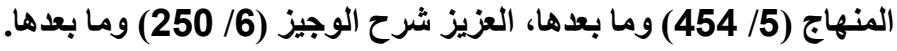

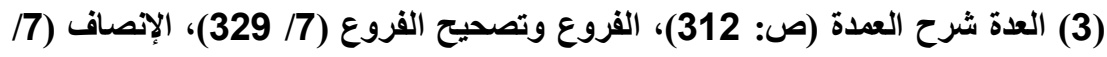

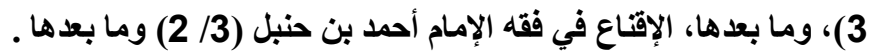

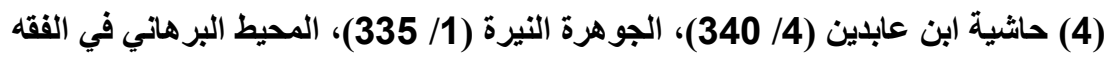

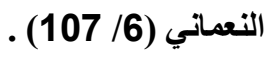
(5) العناية شرح الهاية (6/ (102)، 202، بلغة السالك لأقرب المسالك (4/ 101) . 
يتوقف على الواقف والموقوف عليه والعين الموقوفة، وإن لد يكن

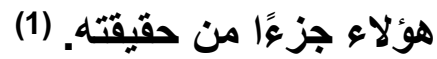

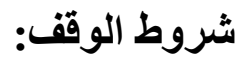

يشترط لصحة الوقف إجمالا ما يلي:

1 - 1 - شروط الو اقف:

أـ أن يكون الواقف أهلاً للتبرع، بأن يكون حراً بالغاً عاقلاً، فلا

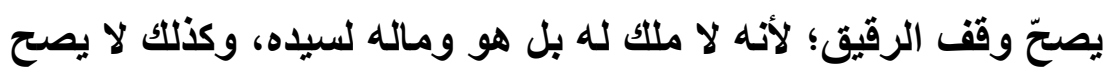
وقف الصبي والمجنون؛ لأن الصبي والمجنون لا عبارة لهما شرعاً،

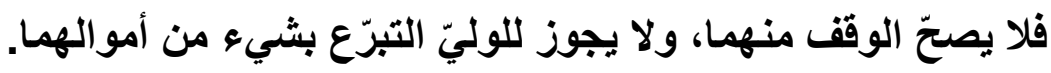

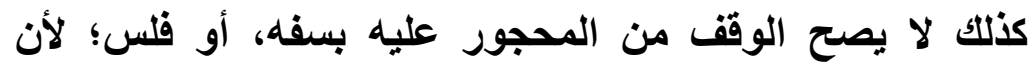
هؤلاء ممنوعون من التصرّف بأموالهم، فلا يصح منهم التبرّع، ولا لاله

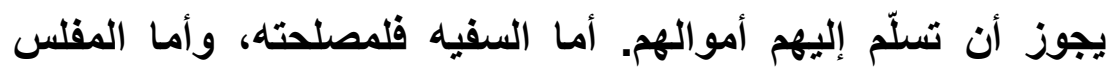

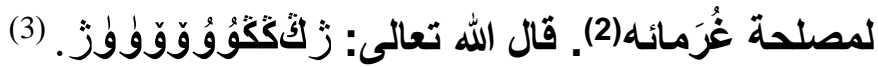

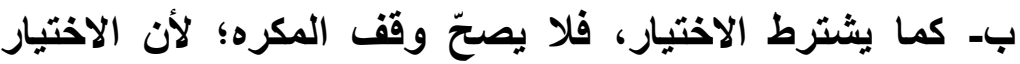
شرط من شروط التكليف.

ج - كما يشترط أن يكون الو اقف مالكاً لما يريد وقفهـ

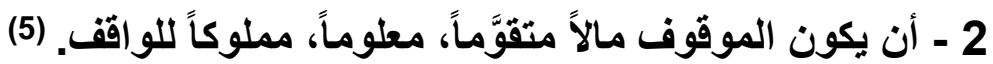

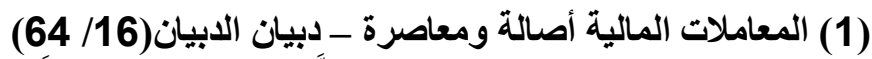

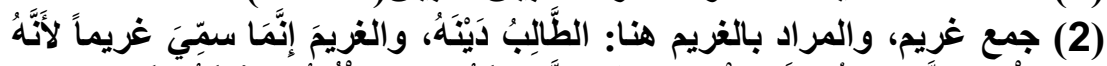

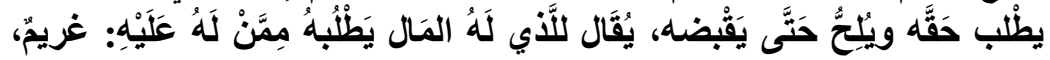

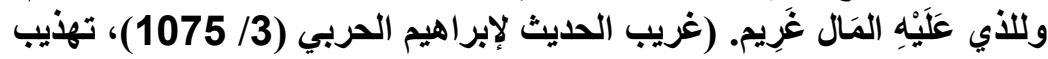

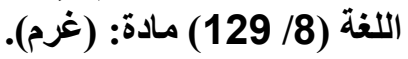

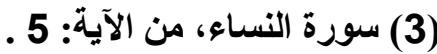

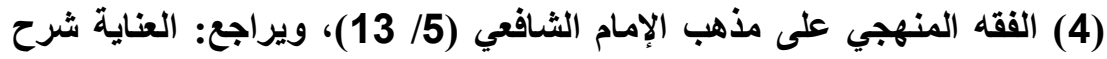

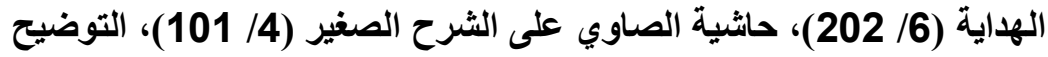

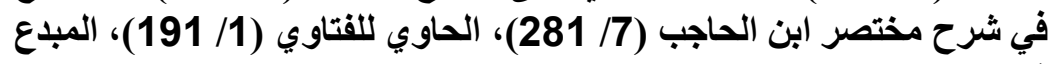

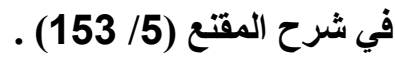

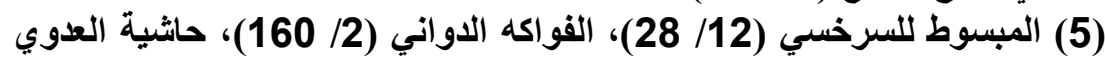

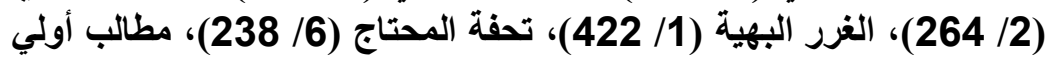
النهى (4/ 332) . 
3 - أن يكون الوقف عيناً معلومة يمكن الانتفاع بها مع بقاء

عينها. (1)

4 - أن يكون الوقف على بٍِّ، كالمساجد، والقتاطر، والأقارب،

والفقراء.

5 - أن يكون الوقف على معين، من جهة كمسجد كذا، أو صنف (2)

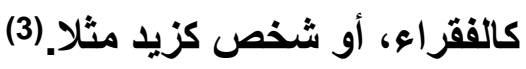

(1) الاختيار لتطليل المختار (3/ 41) اللباب في شرح الكتاب (2/ 180)، (260)، الفواكه

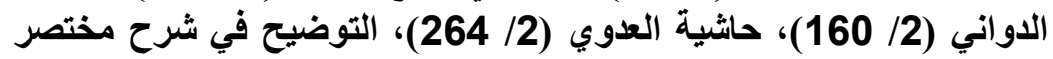

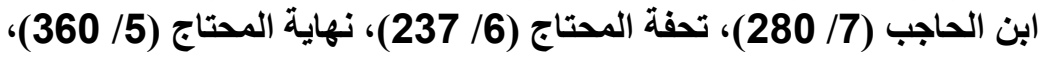

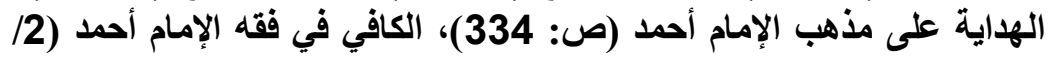

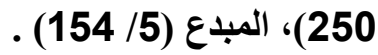

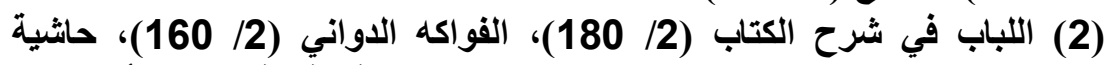

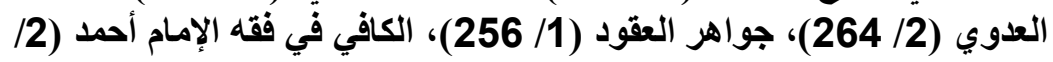

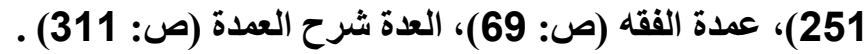

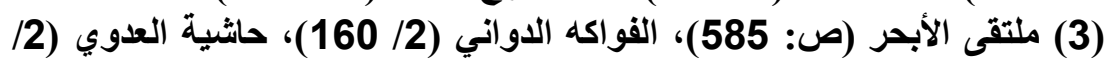

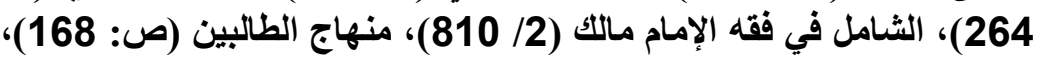
جواهر العقود (1/ 250)، السراج الوهاج (ص: 302)، الإنصاف (7/ (20 ) . 
6 - أن يكون الوقف مؤبداً غير مؤقت، منجّزاً غير معلق، إلا إذا

علقه بموته فيصح ويكون وصية. مشروعية الوقف وحكمه التكليفي وحكمته:

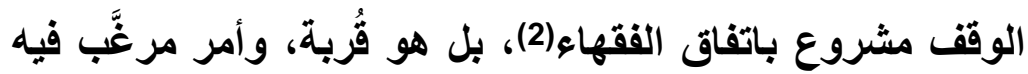

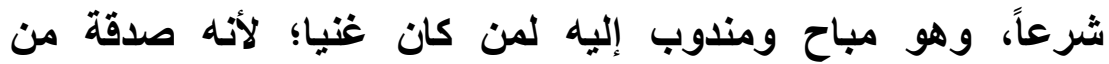
(الصدقات(3).

وقد قامت أدلة الكتاب والسنّة على تقريره وبيان مشروعيته: 1- أما الكتاب، فيستدل منه بالآيات الآتية:

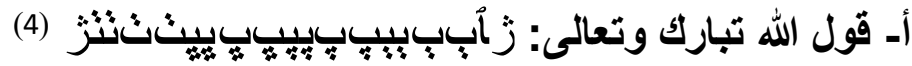
وجه الدلالة من الآية: هذه الآية خطاب للمؤمنين بأنهم لن ينالوا البر(5) حتى يتصدقوا مما يحبون وينفقوا من نفيس أموالهم(6)؛ لأن

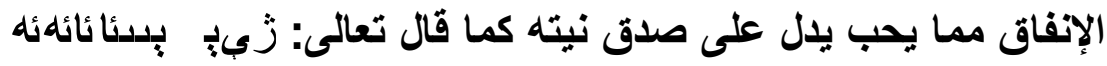

(7)

(1) المبسوط للسرخسي (12/ 32)، تحفة الفقهاء (3/ (160 377)، الفواكه الدواني

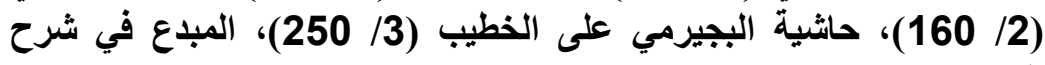

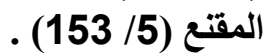

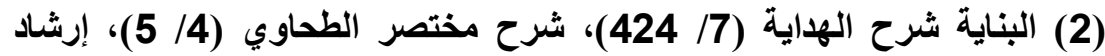

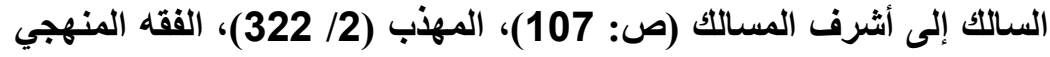

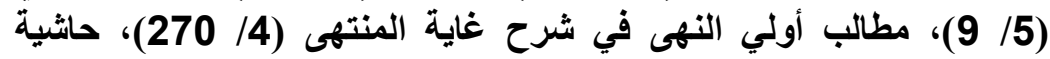

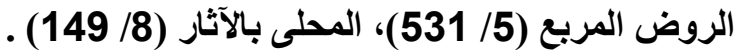

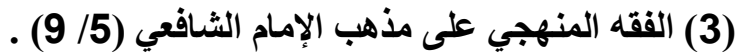

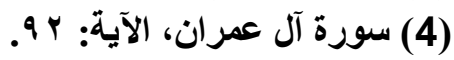

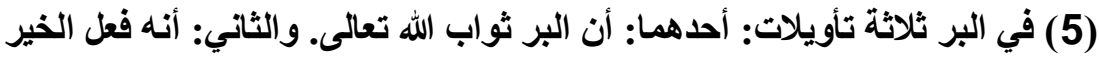

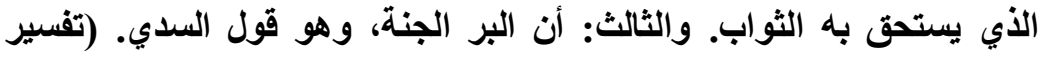

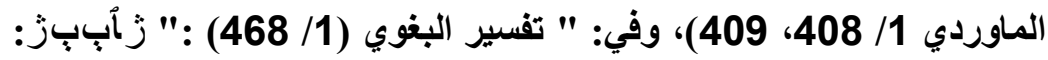

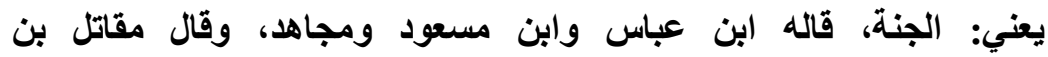

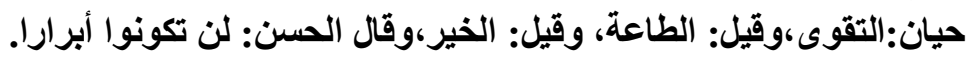

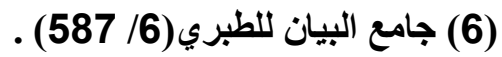
(7) أحكام القرآن للجصاص (2/ (6) 301) . 
قال الحسن: "كل من تصدق ابتفاء وجه الله بما يحبه ولو ثمرة فهو داخل في هذه الآية"'(1). وقد روي أن أبا طلحة ح لما سمع هذه الآية الكريمة رغب في الوقف، وأتى النبي ع يستشيره.

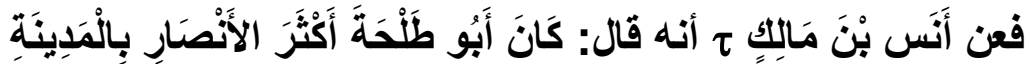

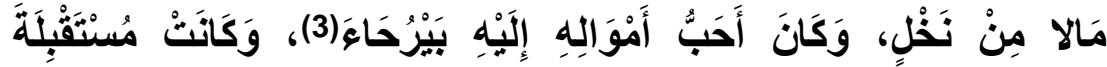

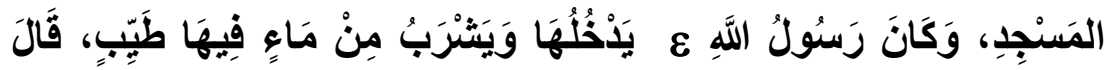

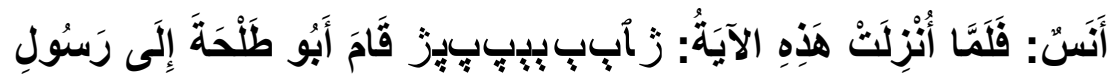

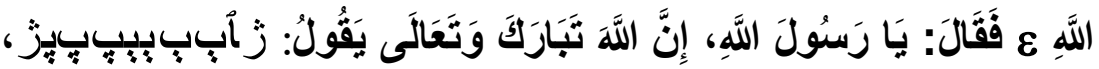

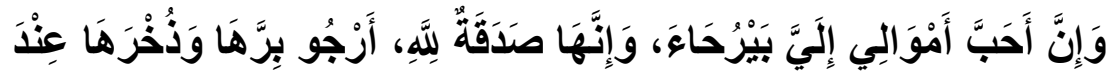

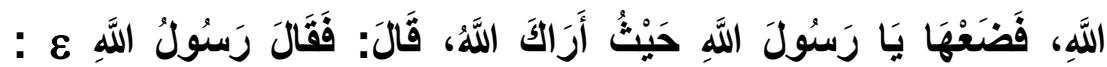

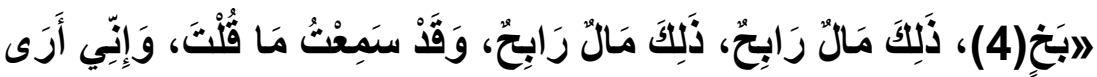

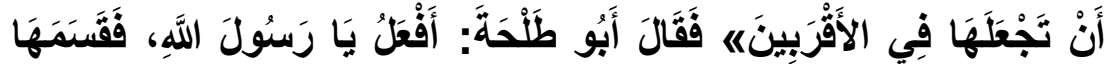

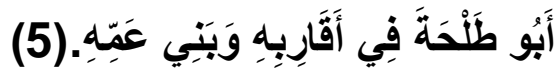

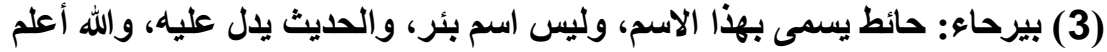

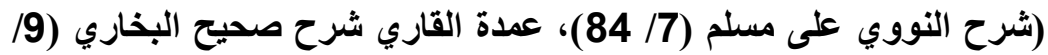

(4) (بخْ): بوزن بل، كلمة تقال عند المدح والرضا بالثيء، وتُكرِّر للمبالغة، فيقال:

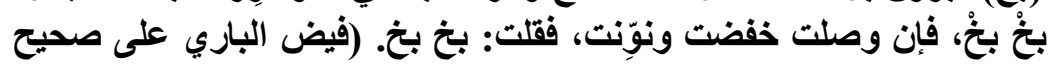

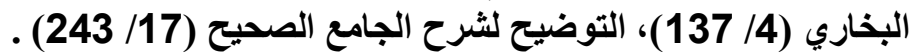

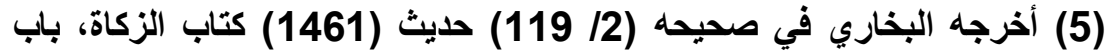

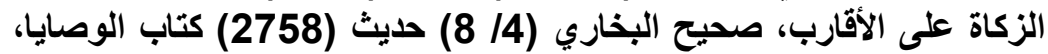

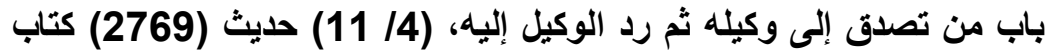

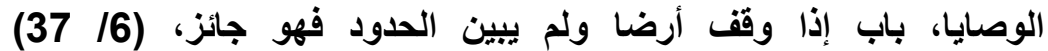

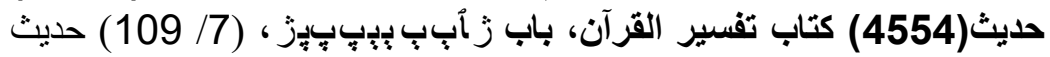
(5611) كتاب الأثربة، باب استعذاب الماء، ومسلم في صحيحه (12/ 


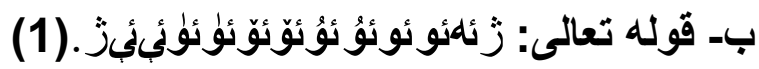

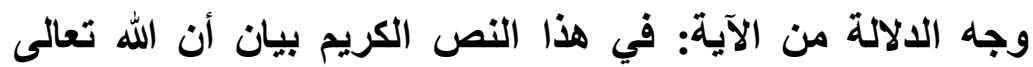

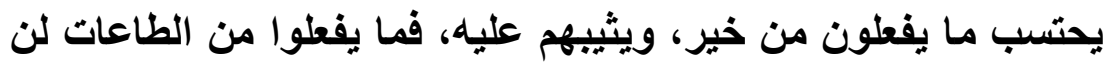

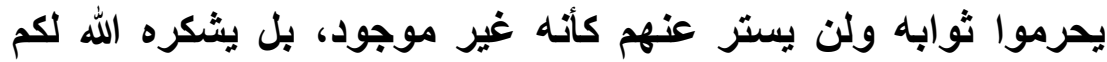

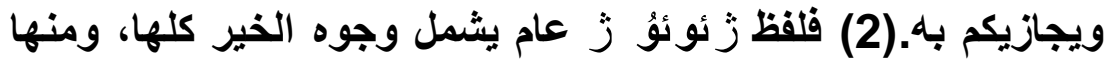
الوقف. (3) (3)

2- 2 وأما السنّة، فأحاديث كثيرة، منها:

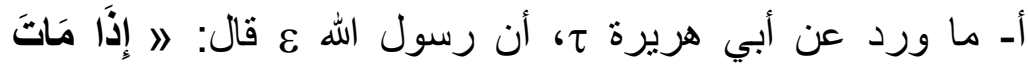

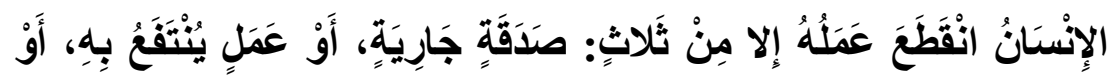

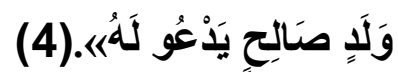

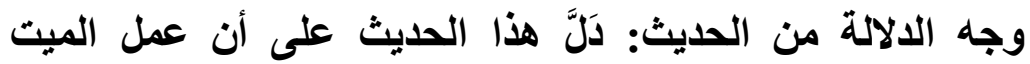
ينقطع بموته وينقطع تجدد الثواب له إلا في هذه الأثشياء الثُلاثة؛ لكونه الها

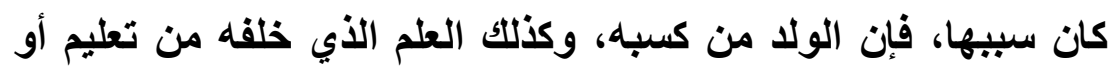
تصنيف، وكذلك الصدقة الجارية، وهي الوقف، فئه وكيه دليل لصحة أصل

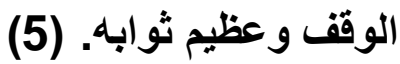

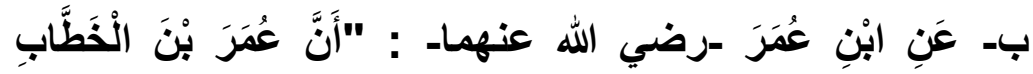

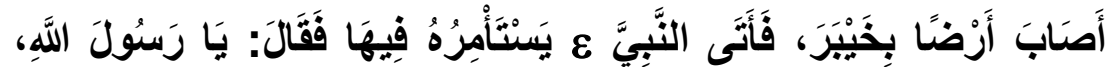

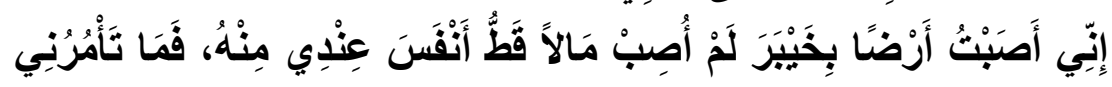

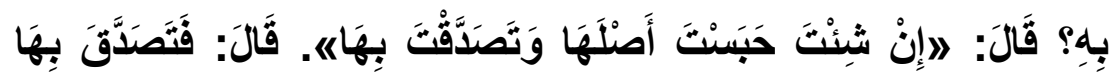

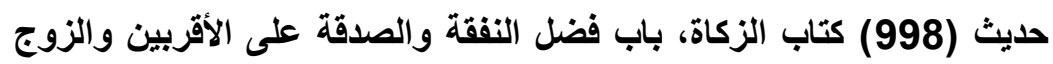

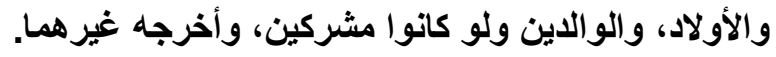
(1) سورة آل عمران، الآية: 115 (2) فتح البيان في مقاصد القرآن (137/2)، (13/2)، تفسير المراغي (37/4)، زهرة

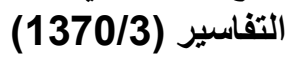

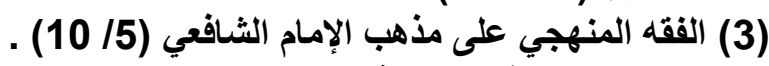
(4) (3بق تخريجه في المقدمة.

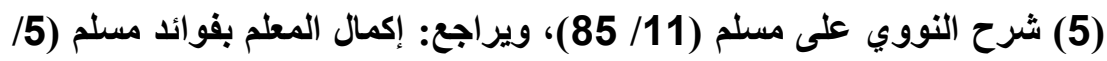

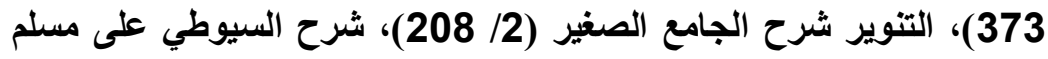




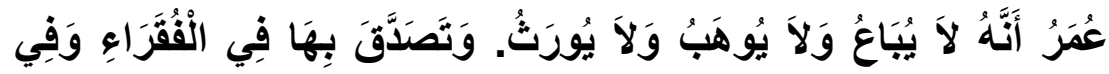

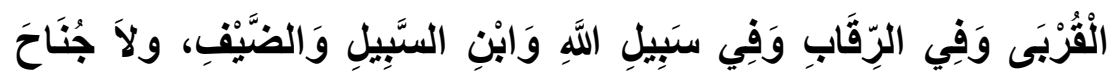

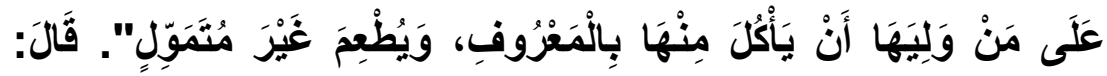

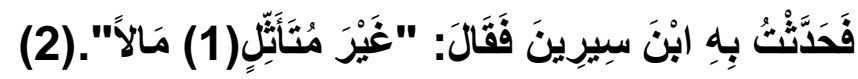

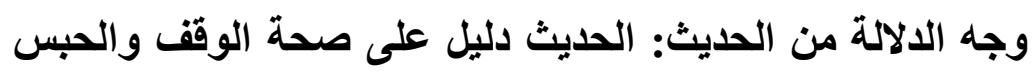

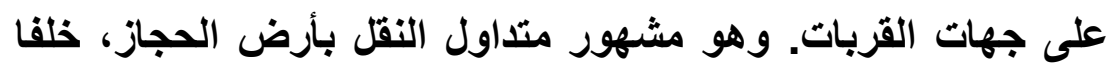

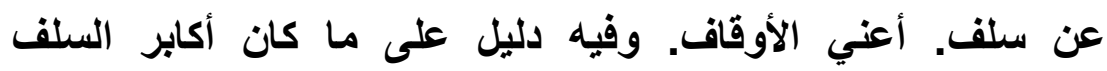

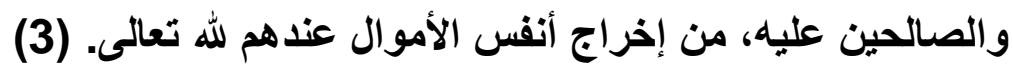

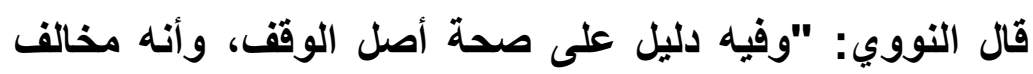

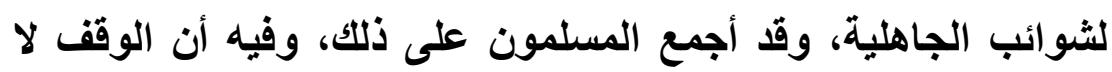

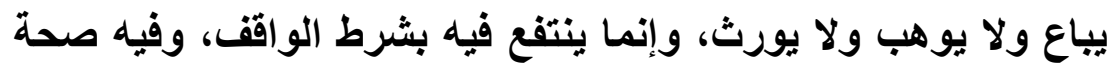

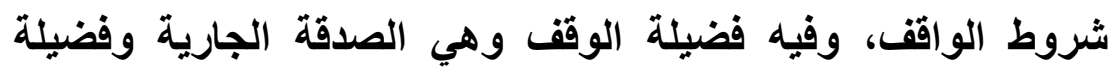

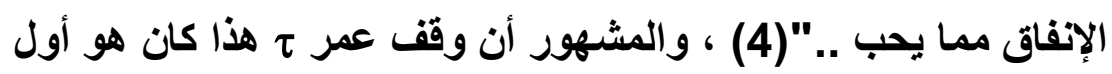

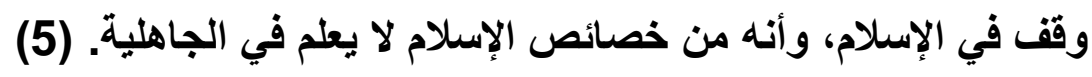
3- 3- 3ي إجماع الصحابة.

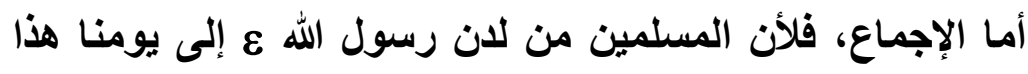

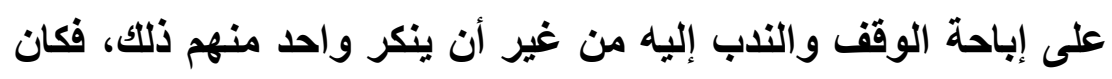

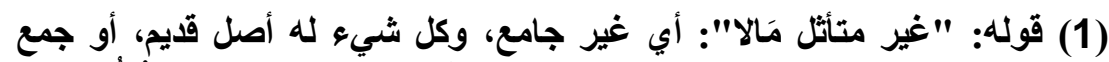

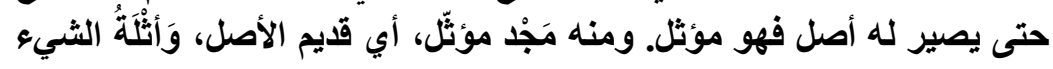

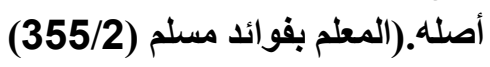
(2) سبق تخريجه عند شرح تعريف الوقف عند الإمامية.

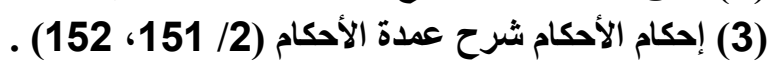
(4) شرح النووي على مسلم (11/ 86)، مرقاة المفاتيح شرح مشكاة المصابيح . $2004 / 5)$ 
إجماعا(1)، وقد اشتهر الوقف بين الصحابة وانتشر، حتى قال جابر : ما بقى أحد من أصحاب رسول الله ع له مقدرة إلا وقف.

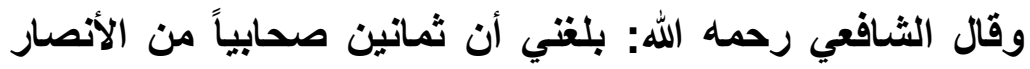

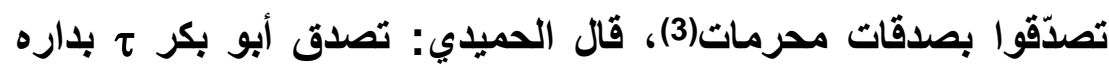

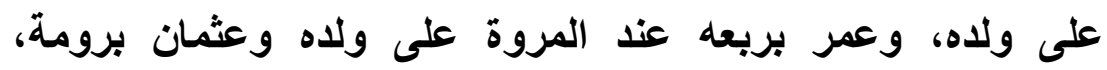

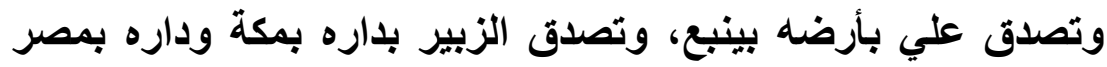

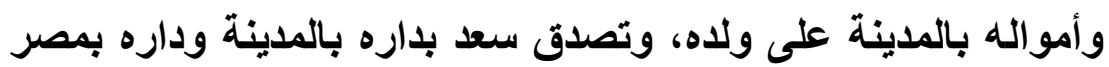

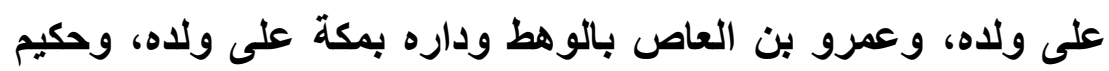

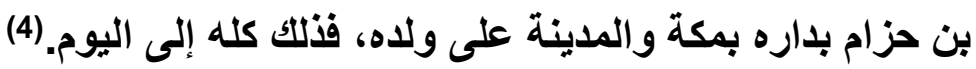

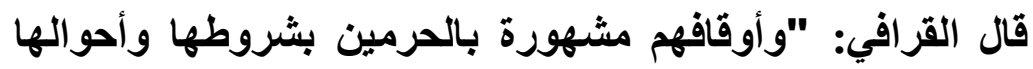

ينقلها خلفهم عن سلفهم، فهم بين واقف وموافق، فكان إجماعا". (5)

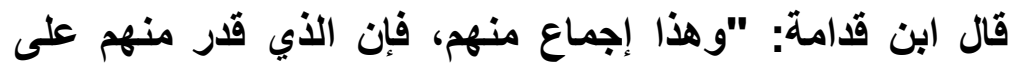

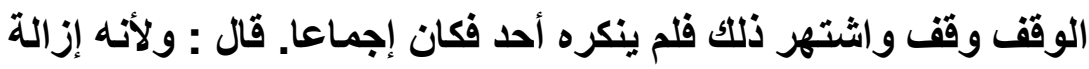

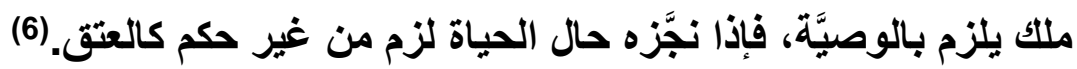
وتتجلى حكمة مشروعية الوقف فيما يلي: بلهئ

(1) البناية شرح الهداية (7/ 424)، شرح مختصر الطحاوي(4/ (5) (5)، إرشاد الفهاد

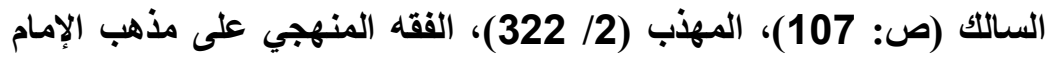

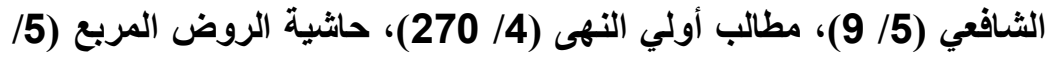

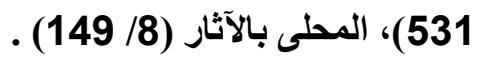

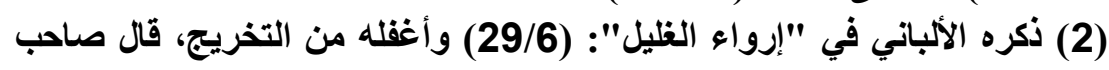

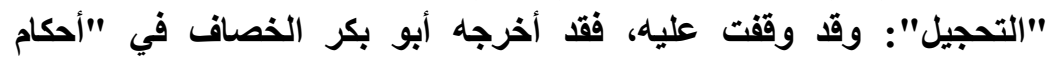
الأوقاف". (التحجيل في تخريج ما لم يخرج من الأحاديث ولهُ والآثار في إرواء

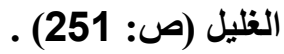

(3) مغني المحتاج إلى معرفة معاني ألفاظ المنهاج (31/ 523) والمراد بقوله: (بصدقات محرمات): أي وقفوا أوقافاً. (الفقه المنهجي على مذانى مذهب الإمام 
1 - فتح باب التقرب إلى الله تعالى في تسبيل المال في سبيل الله،

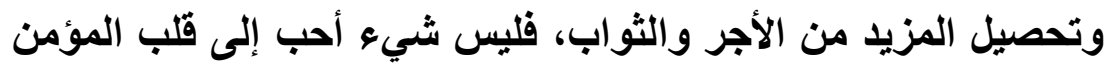

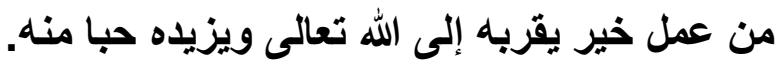

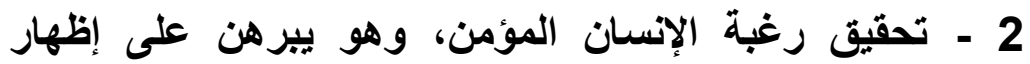

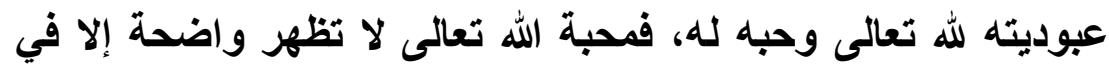

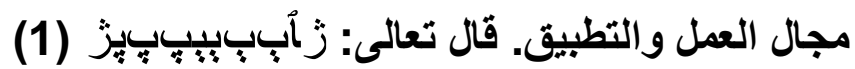

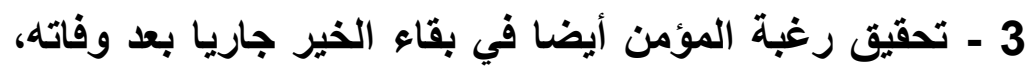

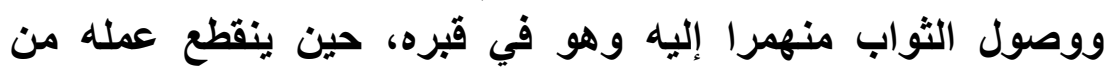

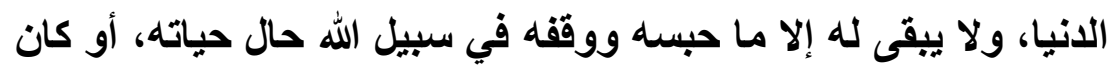

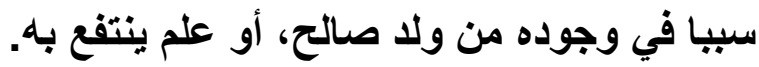

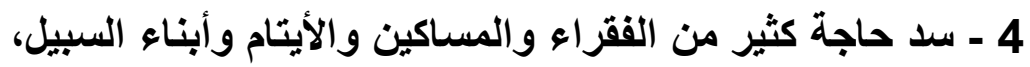
والأين أقعدتهم بعض الظروف عن كسب حاجاتهم، فِإن في أموال

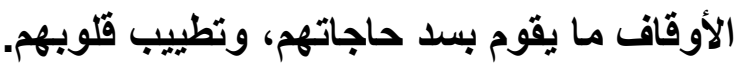

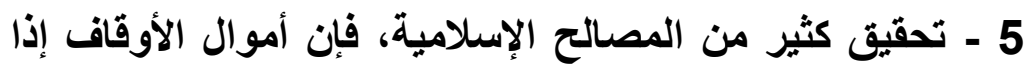

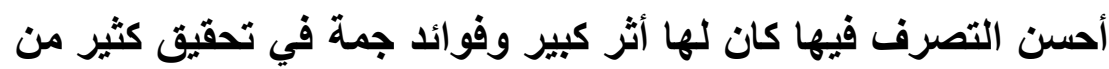

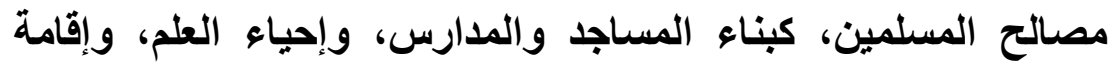

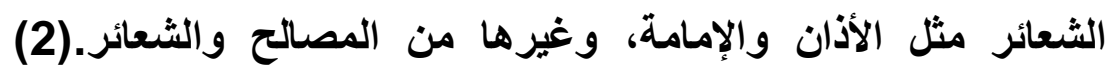

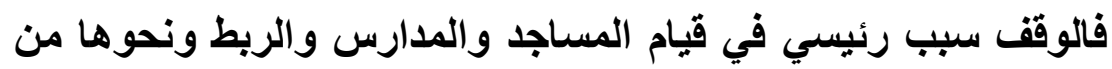

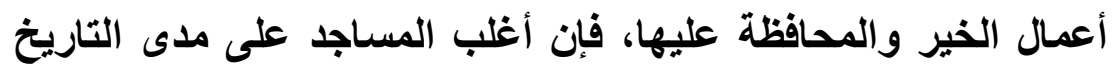

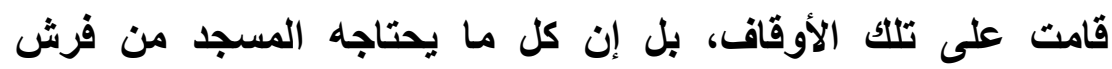

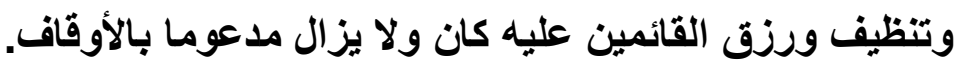

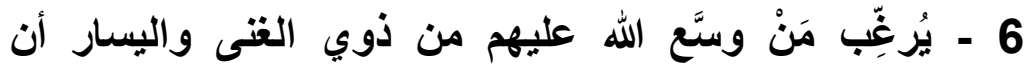

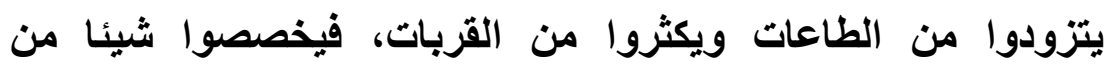

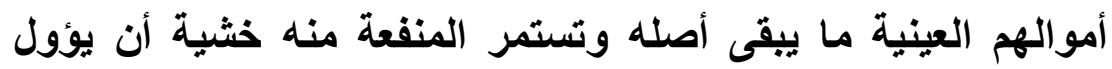

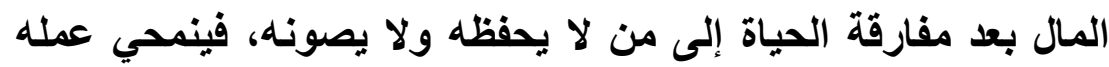

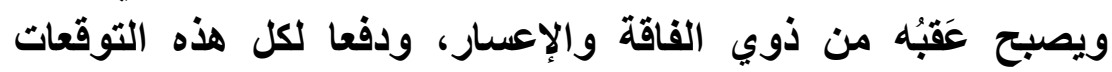

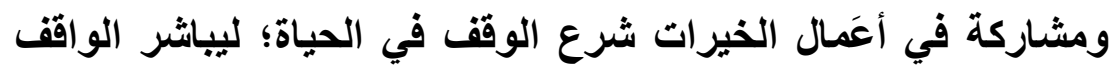

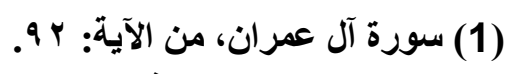

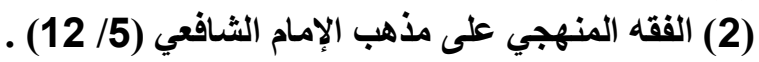


ذللك بنفسه ويضعه في موضعه الأي يريده ويتمناه، وليستمر مصرف

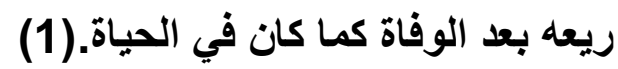
$* * * * *$

(1) رسالة في الفقه الميسر (ص : 112) ، ويراجع: موسوعة الفقه الإسلامي (3) 
الفرع الثاني: تعريف التقود.

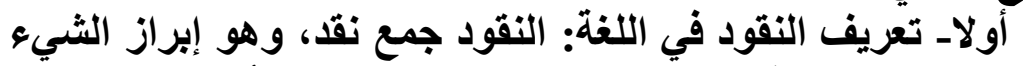

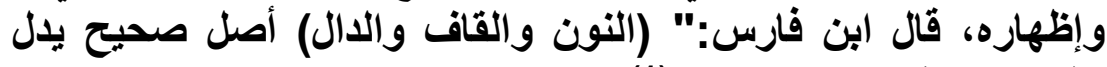

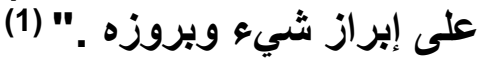

والنقد في اللغة يطلق على عدة معان، منها:

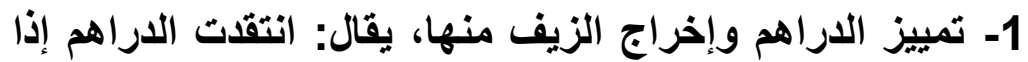

نظرتها لتعرف جيدها وزيفها.

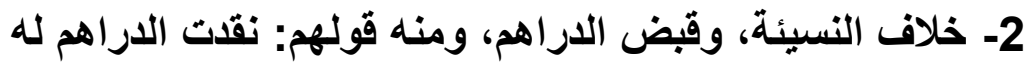

فانتقدها أي قبضها.

3- إعطاء النق: قال الليث: النقا: تمبيز الاراهم وإعطاؤها إنسانا

وأخذها. (4) (c)

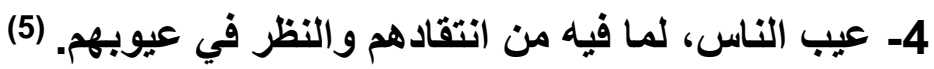

5- العملة من الذهب والفضة.

ثانيا- تعريف النقود في الاصطلاه من التهاح:

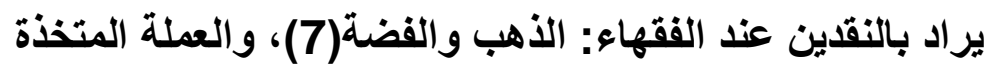

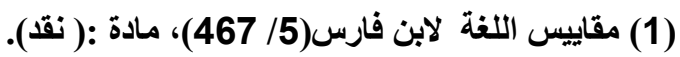

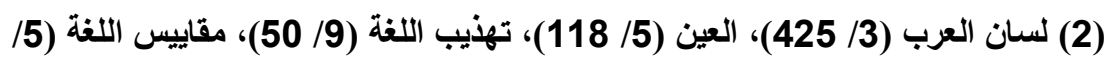

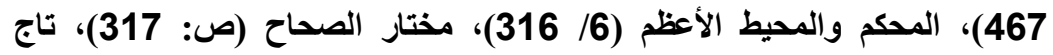

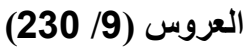

(3) لسان العرب (3/ 425)، الصحاح تاج اللغة وصحاح العربية (2/ 316/230)، 544)، المحكم

و المحيط الأعظم (316/ 316)، (425)، مادة:( نقان).

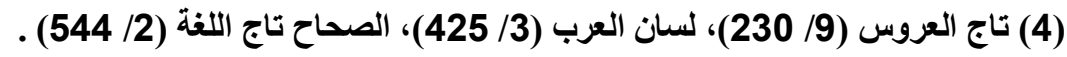

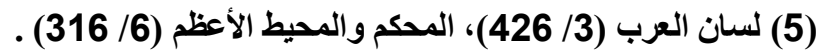

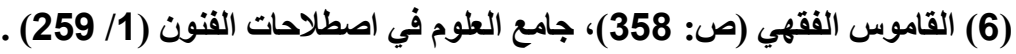

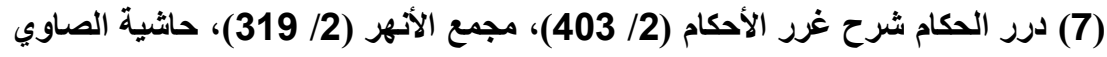

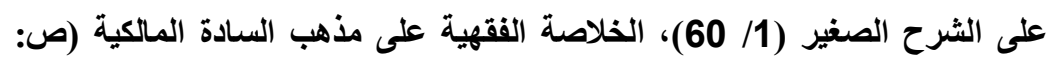

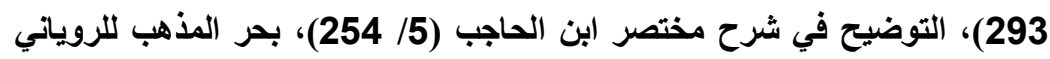

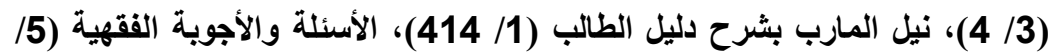

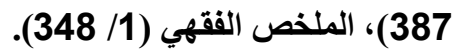


منهما من دراهم ودنانير ويعبر البعض عن ذلك بالأثمان. (1) أما في اصطلاح الاقتصاديين فيعرف النقل بتعارف منقاربة ونئ منها: 1- ما استخدمه الناس مقياساً للقيم، ووسيطاً في التبادل، وأداة

نلادخار. (2)

2- كل وسيط للتبادل يلقى قبولا عاما مهما كان ذلك الوسيط،

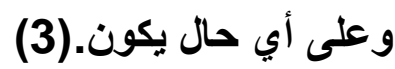

فمن هذه التعاريف يتبين أن علماء الاقتصاد اشترطوا في النقا ثلاث خصائص، متى توفرت في مادة ما اعتبرت هذه المارئ المادة نقاء: الأولى: أن يكون وسيطا للتبادل. الثانية: أن يكون مقياسا للقيم. النئ. الثالثة: أن يكون مستودعا للثروة.

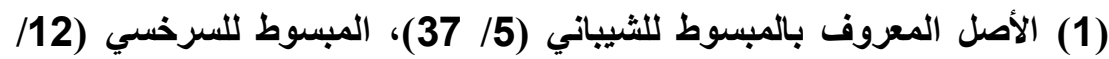

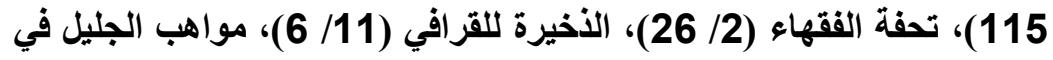

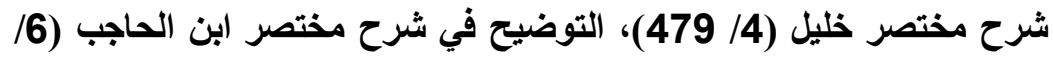

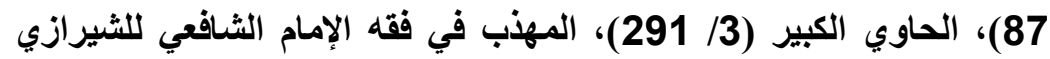

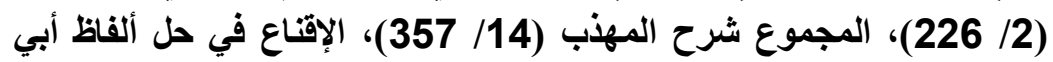

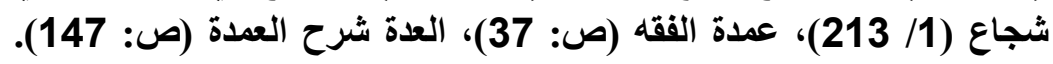

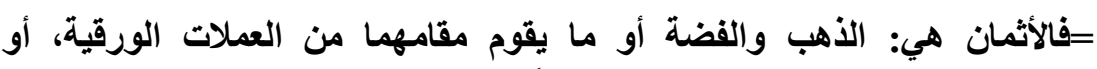

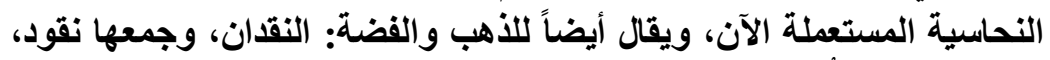

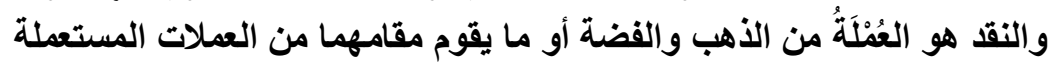

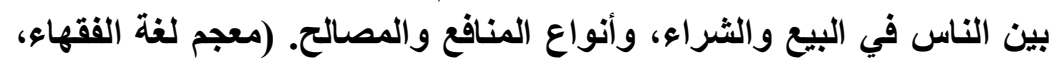

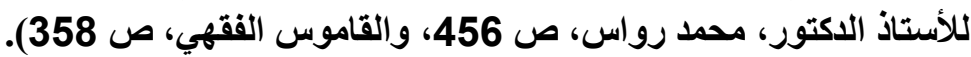

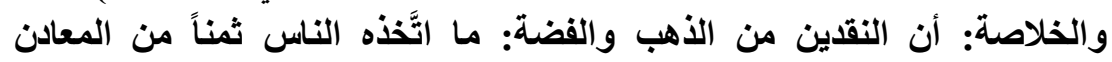

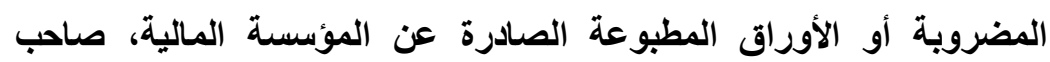

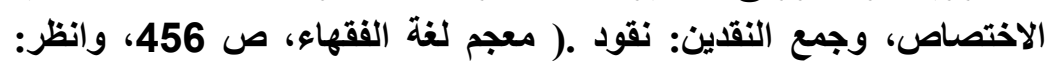

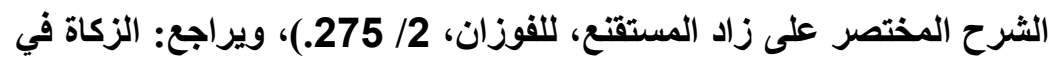

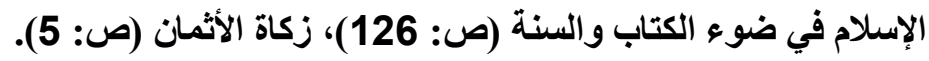

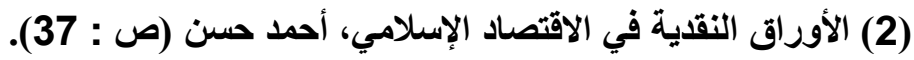
(3) بحوث في الاقتصاد الإسلامي ( ص: 178). 
وعلى هذا الأساس قيل: إن النقـ هو أي شيء يلقى قبولا عاما

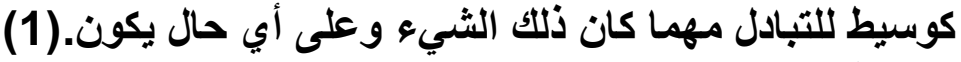

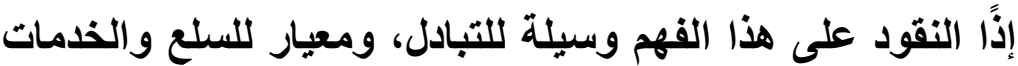

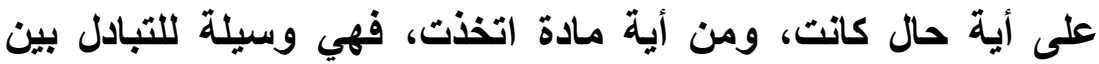

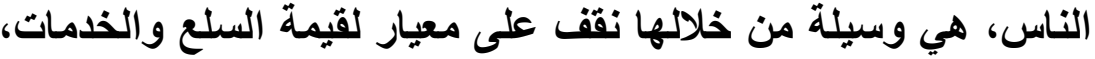

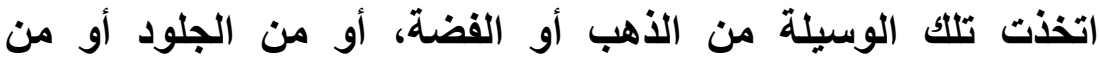

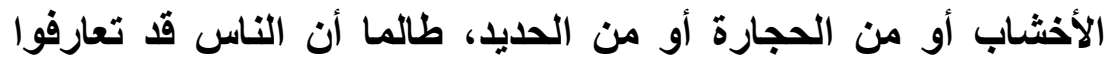
على اعتبار ها نقودًا.

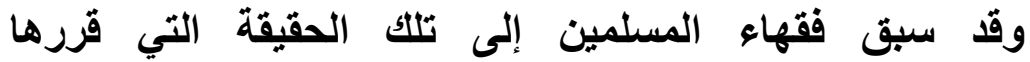

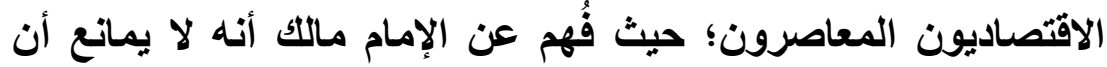

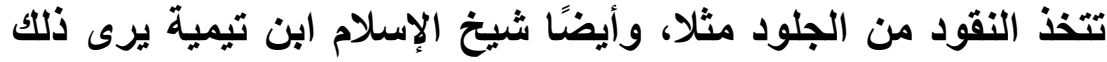

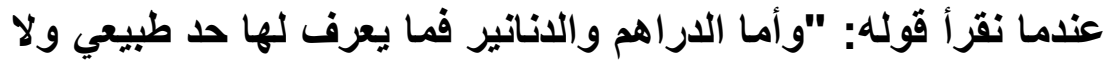
شرعي". كأنه يريد أن يقول: مرجع النقود والتعامل بالنقود العرف

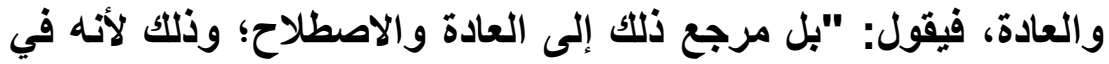

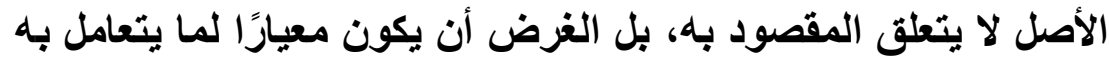

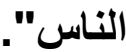

إذًا يريد أن يقول: الدراهم والدنانير لا تقصد لنفسها ولا تقصد

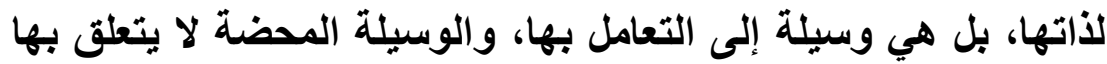

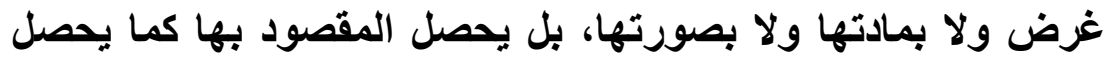
المقصود بغير ها.

وقال ابن القيم:" الأثمان لا تقصد لأعياتها، بل يقصد التوصل بها فيا

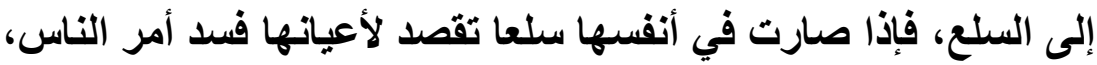

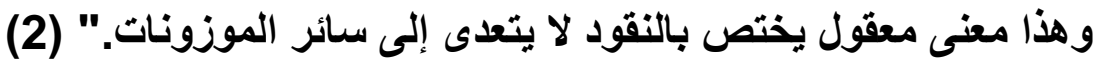

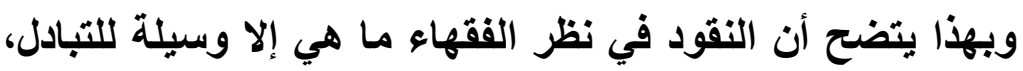

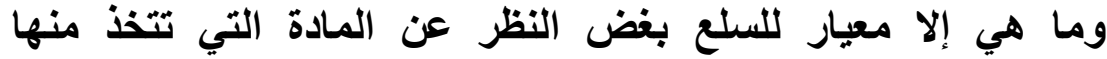

(3). النقود 
وقد كان النقد مقصوراً على الذهب والفضة سواء كانا مسكوكين

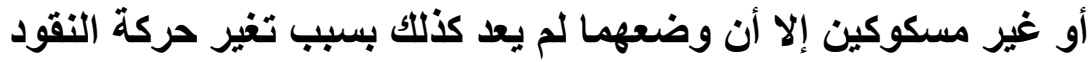
من مادتي الذهب والفضة إلى العملة الورقية الائتمانية أو الالكترونية.

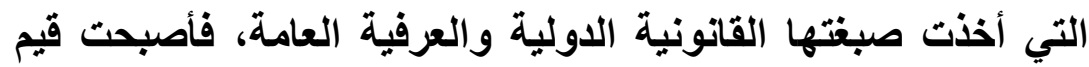

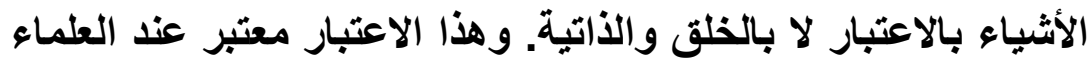

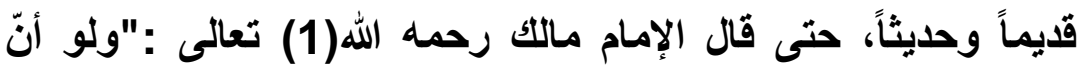

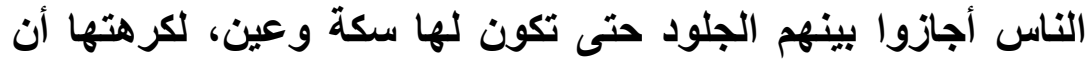

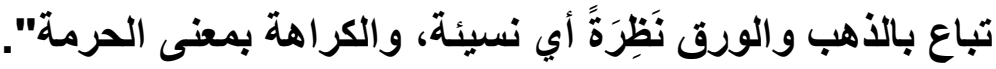

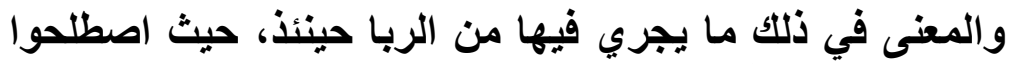

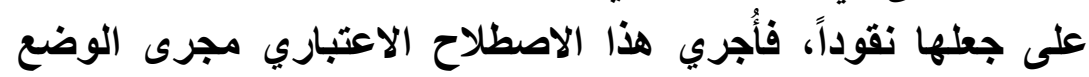

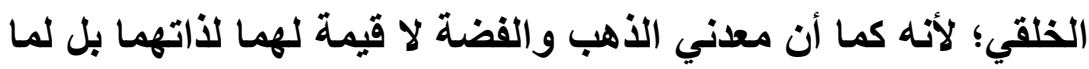

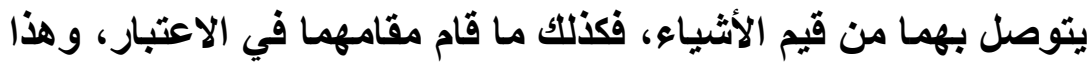

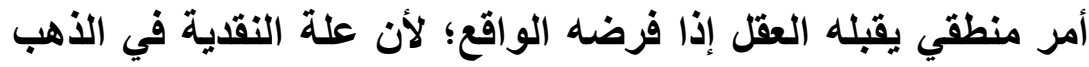

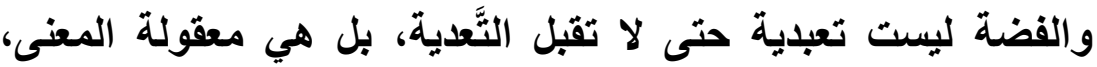

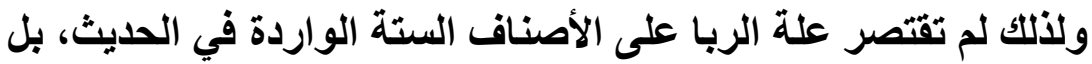

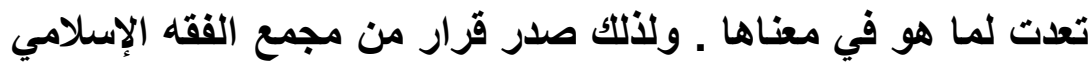

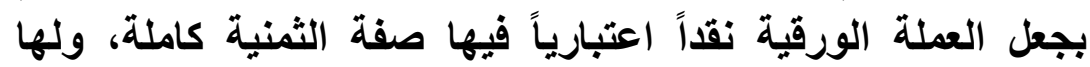

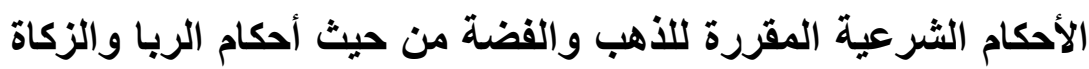

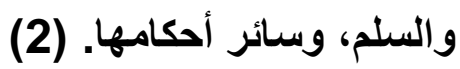

وقد ناقش المجمع الفقهي الإسلامي التابع لرابطة العالم الإسلامي

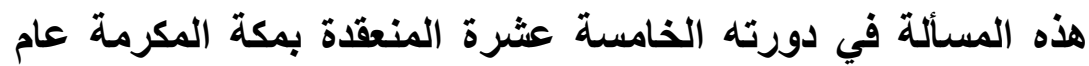

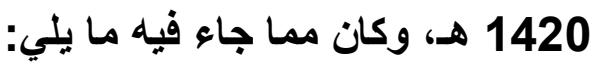

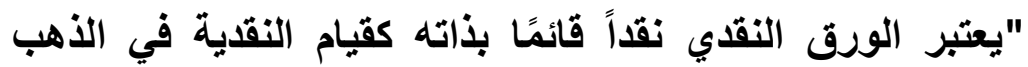

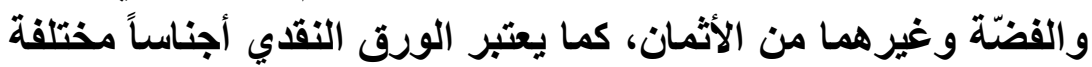

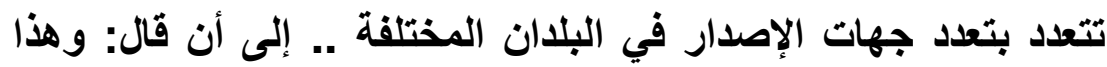

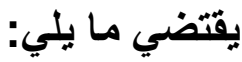

(2) قرارات مجمع الفقه الإسلامي المنبثق عن منظمة المؤتمر الإسلامي ص : 82، وقرارات المجمع الفقهي الإسلامي التابع لرابطة العالم الإسلامي صن: 
1- أنه لا يجوز بيع الورق النقدي بعضه ببعض أو أو بغريه من

الأجناس النقدية الأخرى من ذهب أو فضة أو أو غير هما نسيئة مطلقاً .

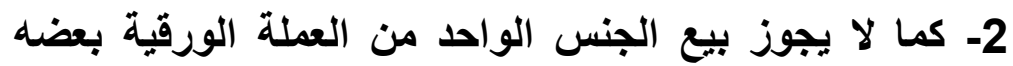

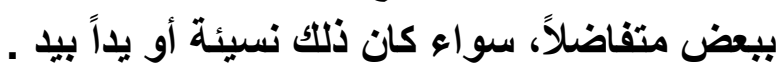

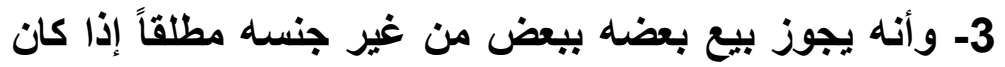

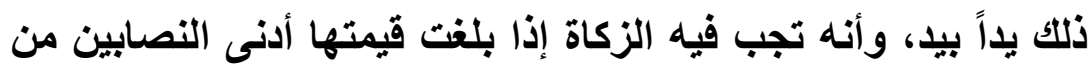

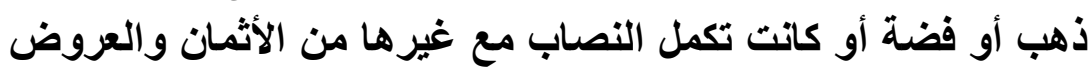

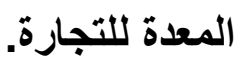

4- وأنه يجوز جعل الأوراق النقدية رأس مال في بيع السلم

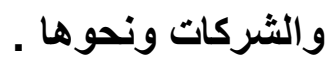

وبهذا يتبين أنه لم يعد هناك إثكال في وضع العملة الورقية

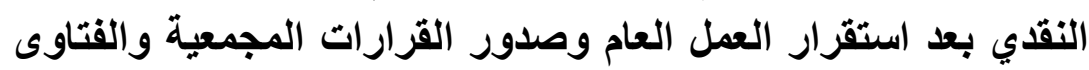

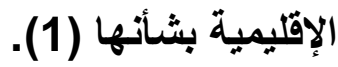

الفرع الثالث: تعريف وقف النقود.

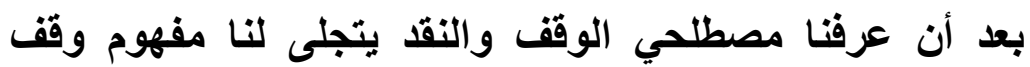

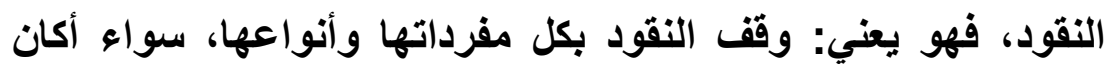

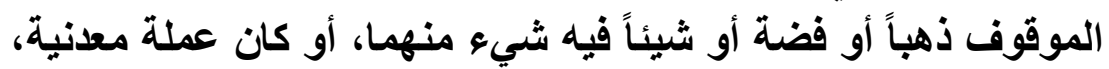

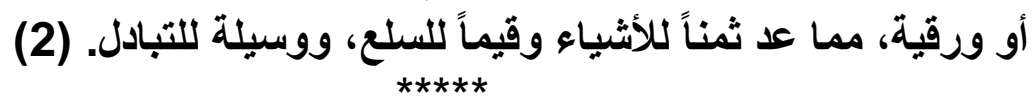

(1) قرارات المجمع الفقهي الإسلامي ص 101 - 103، ويراجع: من فقه الوقف، د. أحمد الداد ص33 الفيع وما بعدها.

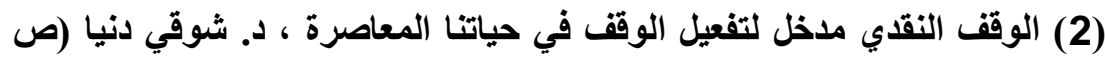

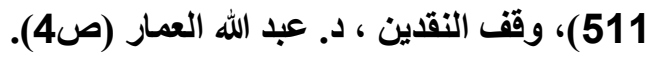




$$
\text { المطلب الثاني }
$$

نشأة النقود، وأشكالاها المعاصرة

الفرع الأول: نشأة النقود. أولا: نشأة النقود قبل الإسلام:

قبل الإسلام كانت هناك صيخ معينة يتعامل الناس بها، ويتبادلون

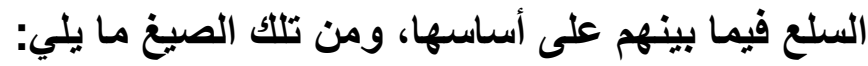

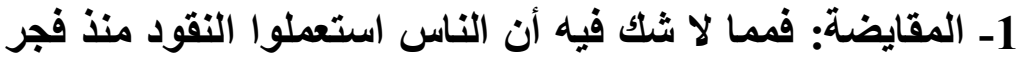

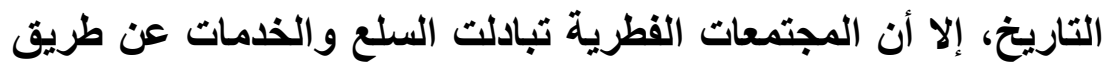
المقايضة، وتتمثل أو نتخيل المقايضة بأنها معاوضة عرض الهات بعرض؛

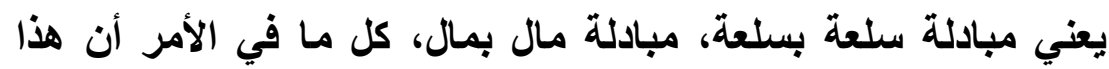

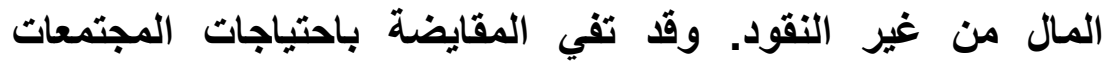

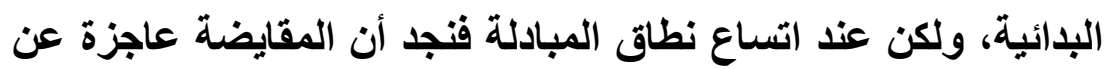

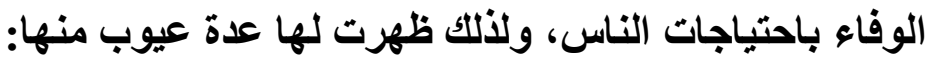

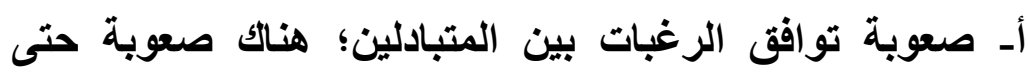

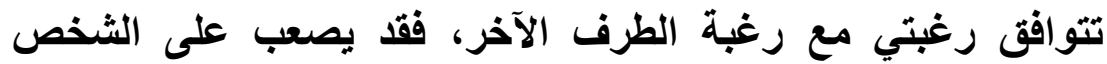
العثور على شخص آخر يجد عنده السلعة التي يرغب الطب فئها.

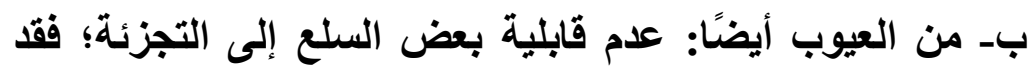

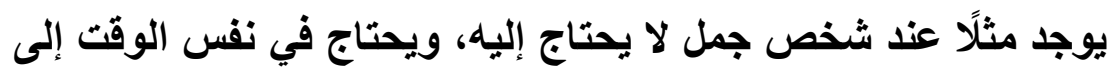

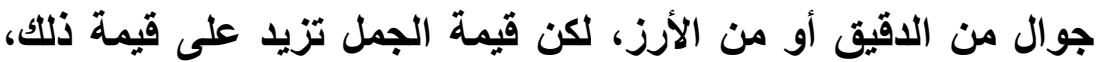
والجمل لا يمكن تجزئته؛ هنا يمتنع التبادل.

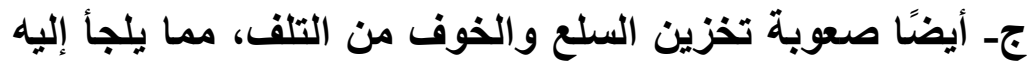
المقايض، فقا يضطر المقايض نتيجة صعوبة تخزين السلع، أو نتيجة

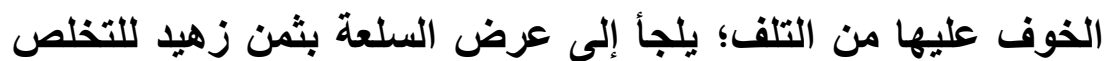
من التخزين أو لإنقاذها من التلف.

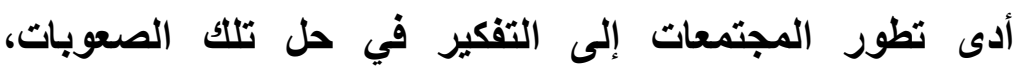

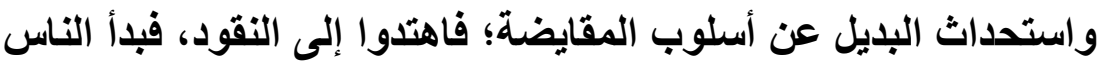
بالنقود السلعية، ثم المعدنية. 
2- النقود السلعية: هناك أيضًا من الأنظمة التي كانت موجودة قبل الإسلام، ويتم على أساسها التبادل وتلاقي الرغبات النقات النقود السلعية، فبعد أن أحس الناس بصعوبة المقايضة انتقلوا إلى مرحلة النقود

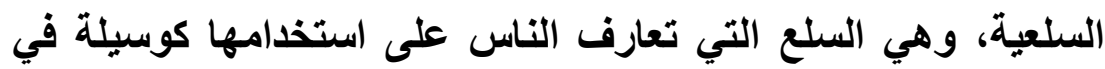

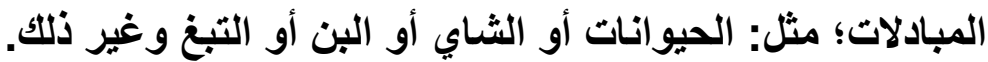

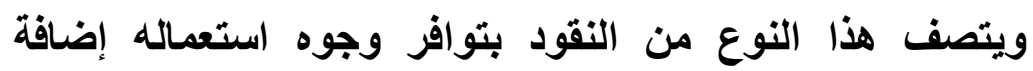

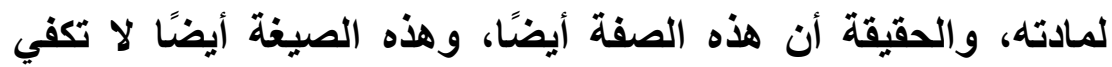

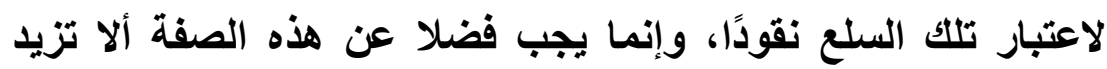

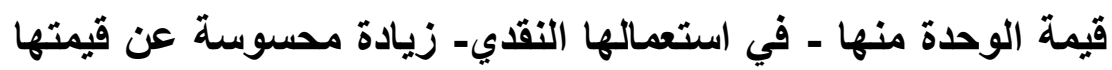

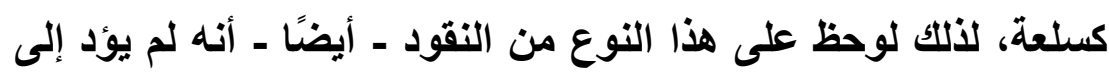

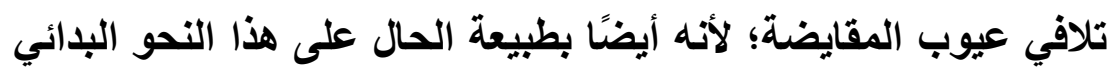

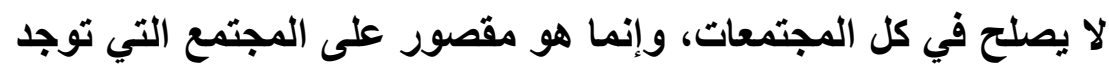
فيه تلك السلعة مثلا. 3- النقود المعدنية: من الصيغ أيضًا التي كانت موجودة ويتعامل

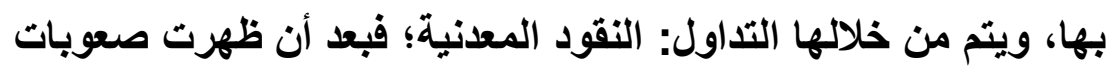

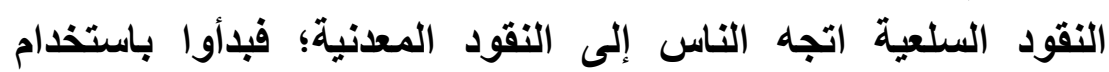

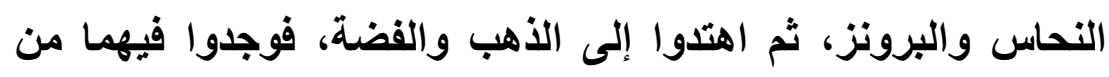

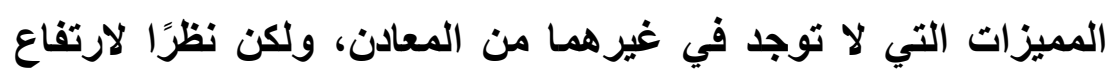

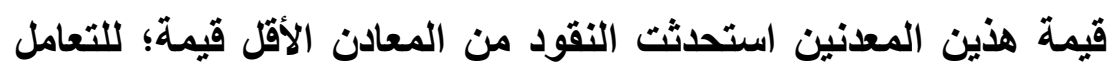

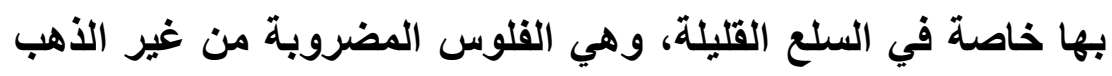
والفضة، واصطلح الناس على اعتبارها ثمنًا للأشياء.

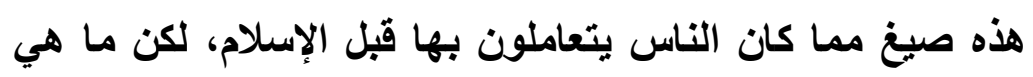
وظائف النقود في نظر أهل الاقتصاد؟

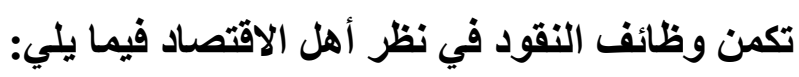

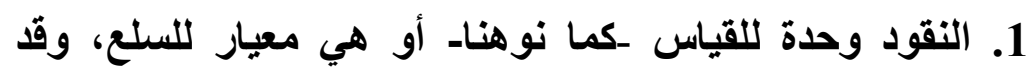

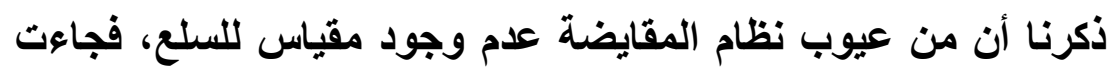

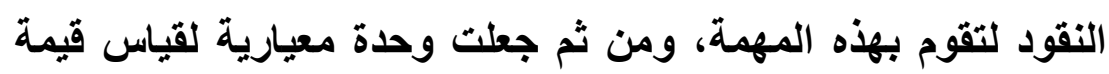


2. النقود وسيط للمبادلة وتحقيق للرغبات، هذه الوظيفة في نظر باد باد

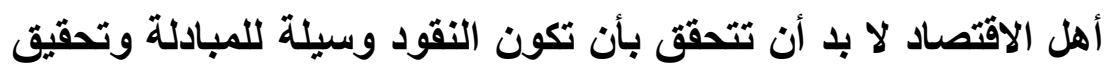

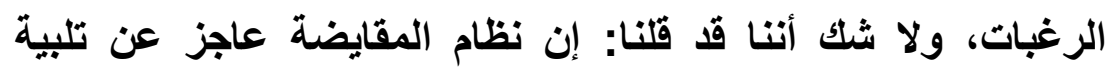

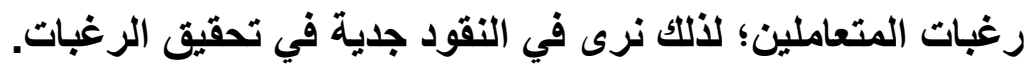

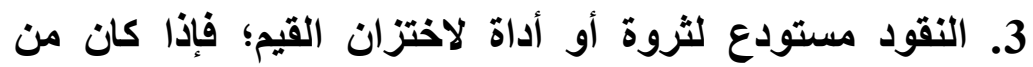

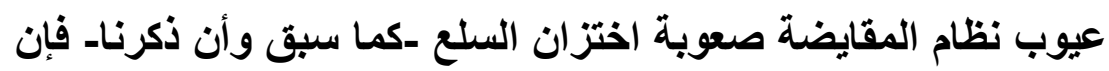

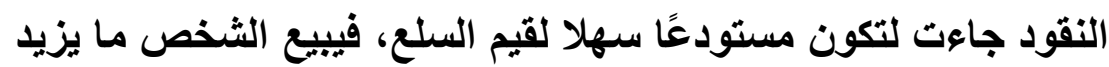

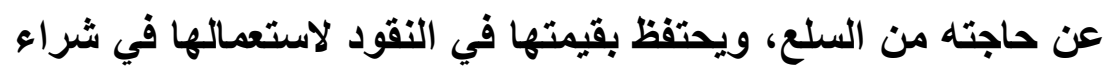
السلع، التي يحتاج إليها في فترات لاحقة.

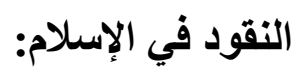
من المعروف أن النبي ع بُعث والناس يتعاملون بنقود الروم الرادي والفرس؛ فقد ذكر البلاذري ذلك فقال: "كانت دنانير هرقل ترد على أهل

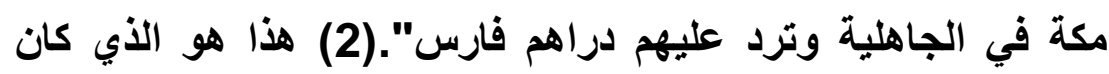

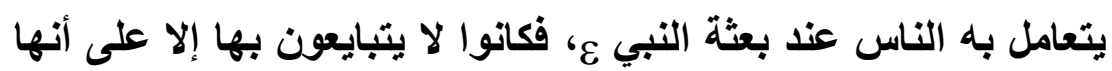

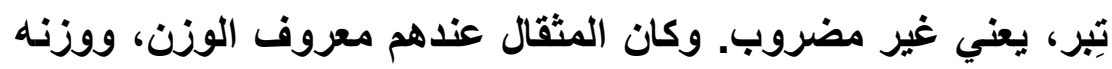
يساوي كذا وكذا وكذا. وفي هذا المغنى يقول ابن خلاون: "وكانوا - أي: العرب يتعاملون بالذهب والفضة وزنًا، وكانت دنانير الفرس ودراهمهم بين

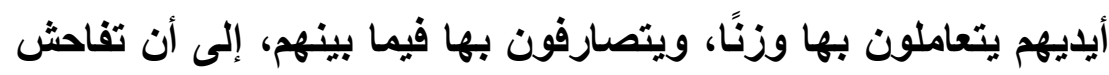

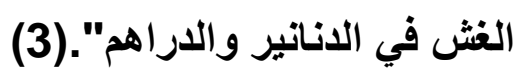
ويقرر أيضًا هذا المغنى المقريزي عندما يقول: "كانت نقود

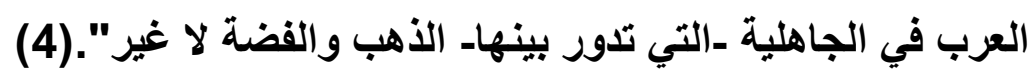

(1) قضايا فقهية معاصرة، د. محمد الجبالي ص 115 وما بعدها، ويراجع:

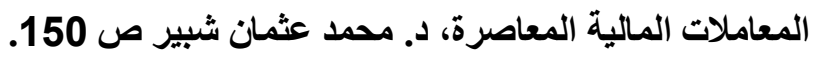

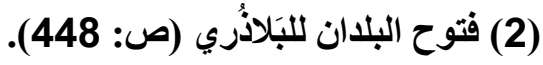

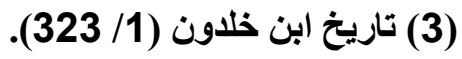
(4) رسائل المقريزي (صل: 157) (323). 
وبعد وفاة التبي ع استمر الخلفاء الراشدون في استعمال التقود

الفارسية والرومية، وبالرغم من انشغالهم بالفتوحات الإسلامية إلا

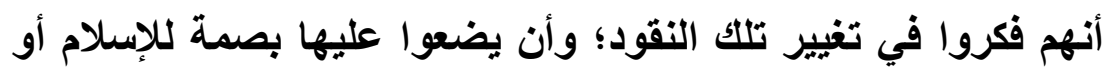
للخلفاء أو لخليفة المسلمين؛ فأضاف عمر ابن الخطاب ح نقوشئا إسلامية على العملات المتداولة، وضرب عمر الفلوس على طراز عملة هرقل، وسجل اسمه عليها، وأضاف كلمة الحمد لله. وكذلك في عهر عبد الملك بن مروان، قام أيضًا بضرب الدنانير والدراهم الإسلامية، ومنذ ذلك الوقت تولت الدولة الإسلامية عملية ضرب النقود وإصدارها؛ لأن الدولة هي التي تقدر حجم المشكلة، وهي الإسلهاي التي تقدر على تحديد كمية النقود اللازمة؛ لحسن سير النشاط الاقتصادي في المجتمع، دون الإضرار بالمصالح الخاصة أو العامة.

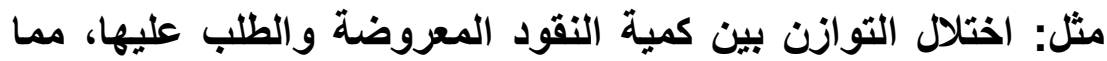
يؤدي إلى التضخم أو الانكماش مما يضر بالدولة والأفراد.

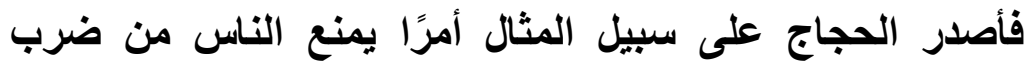

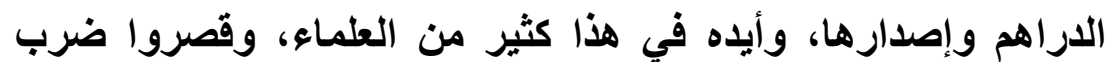

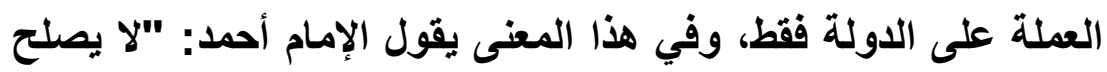
ضرب الدراهم إلا في دار الضرب بإذن السلطان".(1) ولا شك أن هذا (2) اتجاه لله وجاهته. الفرع الثاني: الأشكال المعاصرة للنقود: مما لا شك فيه أن النقود لم تقف في العصر الحديث عند النقود المعدنية، وإنما انتقلت إلى الورقية والمصرفية. فماذا عن النقود الهود الورقية؟ وماذا عن النقود المصرفية؟ المابه

(1) الفروع وتصحيح الفروع (4/ 133)، المبدع في شرح المقتع (2/2/ 359)، (185/3)،

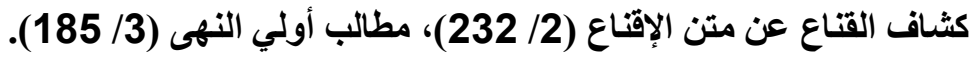

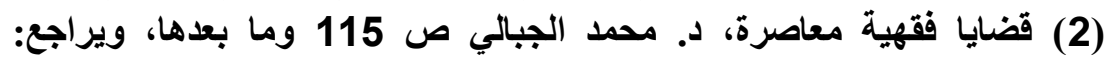

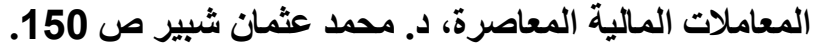




$$
\text { 1- النقود الورقية: }
$$

عندما اتسع نطاق التجارة وازداد حجم المعاملات المالية، لجأ

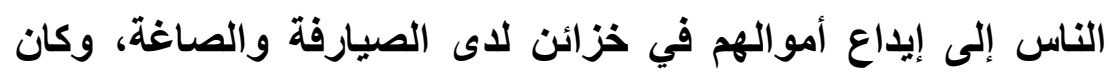

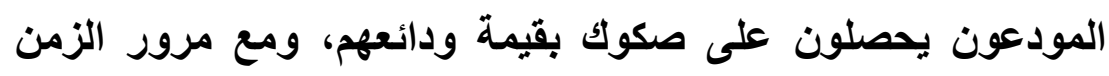
استطاع التاجر أن يقوم بتصغير تلك الصكوك.

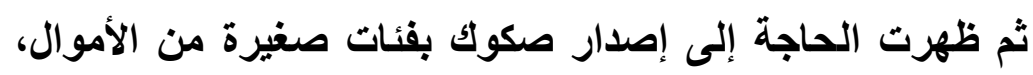

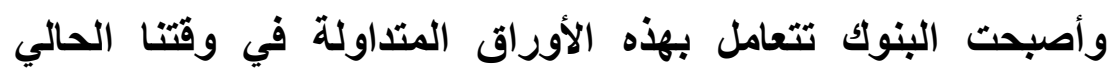

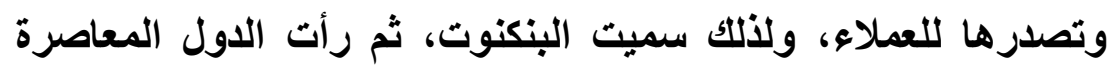
إصدار تلكك الأوراق على شكل نقود، كالنقود الورقية المتاولية بينتا؛ لتأخذ تلك الأوراق الصبغة الرسمية للنقود.

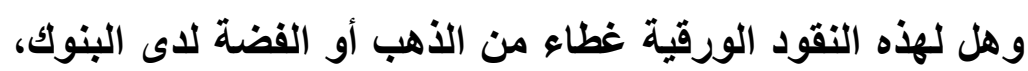

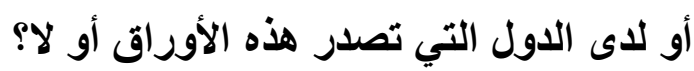
وتتنوع تلك النقود الورقية على أساس الغطاء لها أو عدم الغطاء

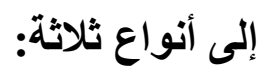

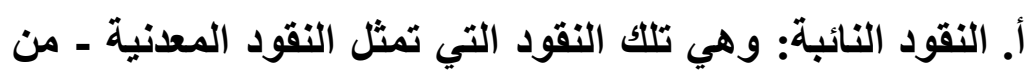
ذهب أو فضة. تمثيلا كاملا، فلا تصدر الدولة أية كمية منها إلا بعد الندان

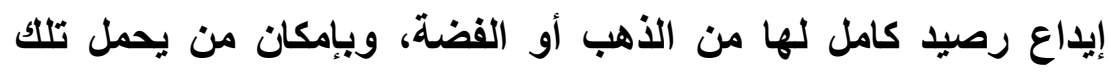

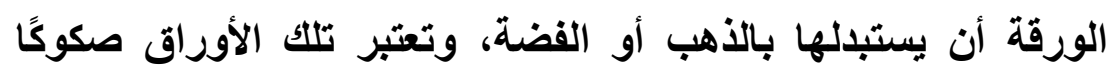

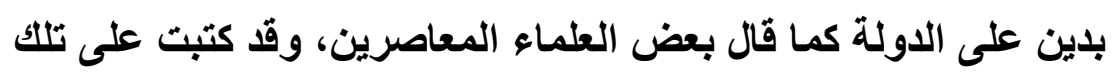

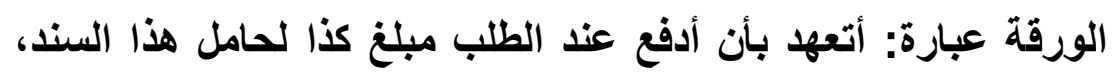

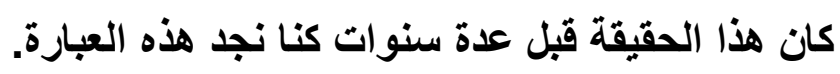

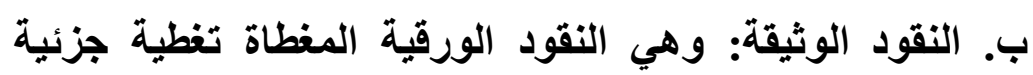

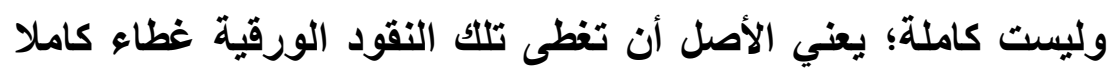

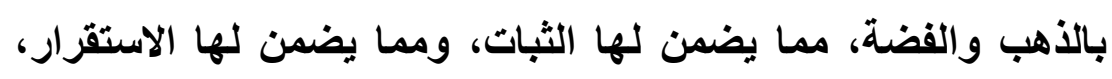

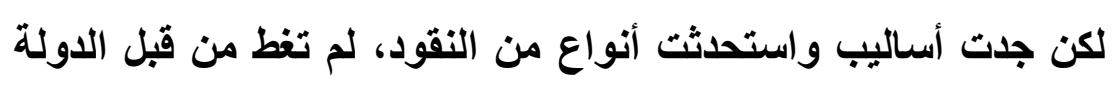

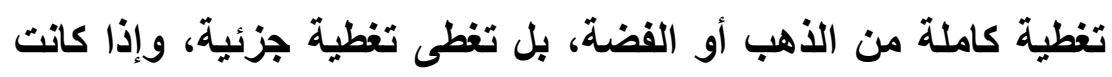

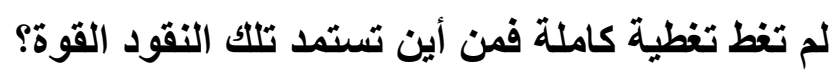


قالوا: تستمد تلكت القوة في الجزء غير المغطى من قوة الاولة التي أصدرت تلكك العملة، ومن ثقة الناس، وقوة تلثئ تلك النقود في الجزء المغطى تستمد من ما رُصد لها من ذهب أو فضة.

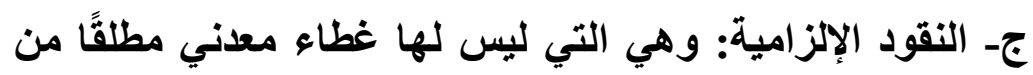

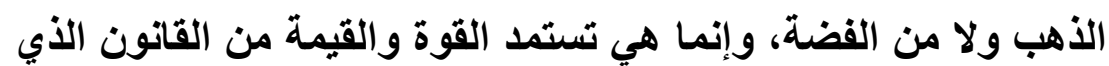
فرضها كعلة للتداول، ومن ثم فلو ألغي التعامل بها لأصبحت عديمة الفيدة

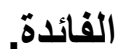

2-النقود المصرفية: وهي الأوراق التجارية التي تصدرها البنوك فورو

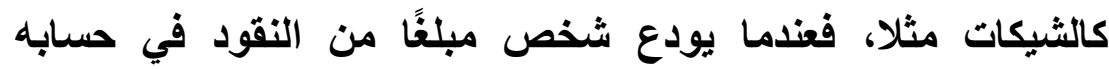

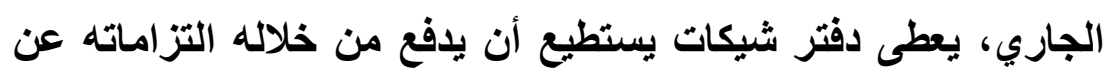
طريق تلك الثيكات، ومن ثم أصبح الناس يتعاملون بها بدلا من النقود

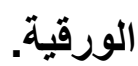

ومما ينبغي التتبيه عليه أن هذه الوسائل لا تعتبر في حد ذاتها

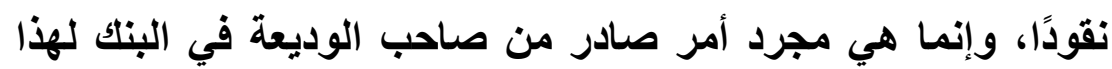

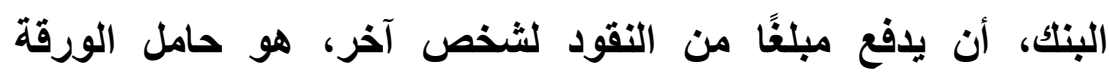
الصادرة من البنك. (1) البع مباك من

$* * * * *$

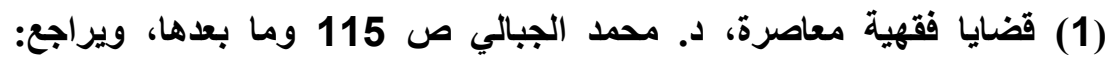

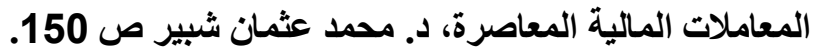


المطلب الثالث

مزايا وقف النقود، ومخاطره

أولا: مزايا الوقف النقدي:

يمتاز الوقف النقدي ببعض الخصائص والميزات. وهذه أهمّها:

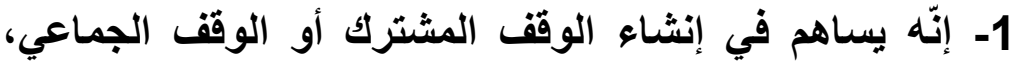

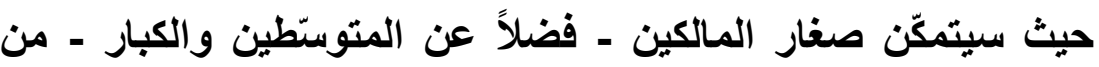
المشاركة جميعاً في مشاريع وقفية واحدة من خلال المساهمة النسبية

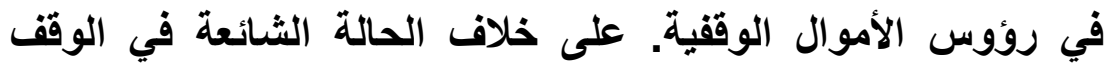

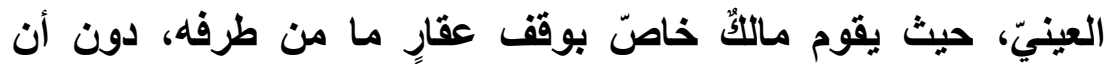
يشاركه أحد في عملية الوقف هذه. 2 - إنّه يراكم رؤوس الأموال، مما يمكّن من إنشاء مشاء مشاريع وقفية كبرى هذه المرّة؛ لأنّ عنصر المشاركة في الوقف سوف يوفّ منّر رؤوس أموال أكبر، من خلال زيادة عدد الواقفين، الأمر الذي يسهّل

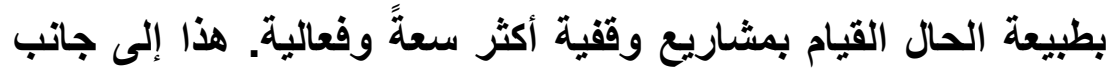
كونه يفسح المجال في دخول الأوقاف مجالاً أوسع من الأنشطة الإتتاجية؛ نظراً لقدة النقد على النفوذ في مختلف أشكال الإنتاج والاستثمار.

3- إنّه يظلة أسهل إنجازاً عن غيره بالنسبة للواقفين؛ لوفرة النقا

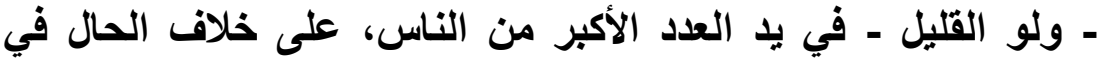
الأراضي والعقارات، فليس كلّ الناس يملكونها أو تثوفّر في أيديهم.

4- أن وقف النقود متاح لمعظم الناس، فعموم الناس يمتلكون ثروات ودخولا نقدية، بينما الكثير منهم لا يمتلك أرضا ولا عقارا . 
5- مما يؤهله (أي الوقف النقي) للوقف الجماعي، وهو اليوم

أكثر ملائمة من الوقف الفردي، كما أنه أكثر أهمية منهـ؛ لعظم ما يوفره

من موارد وأموال وقفية تمكن من إقامة مشروعات خيرية كبيرة.

6- تتوع وتعدد طرق مجالات استثماراته مقارنة بوقف العقار،

كون النقود تثمتع بمرونة عالية من حيث استثمارها. 7- تعدد أغراض ومجالات الوقف النقدي.

8- أن تأثيره التنموي قد يكون أكثر من غيره من حيث إسهامه

في أنشطة إنتاجية مختلفة في مرحلة استثماره.

9- كما أن وقف المنقولات السائلة لا يؤدي إلى تجميد الثروة

وحبسها عن الجريان، بخلاف وقف العقار.(1)

ثانيا: مخاطر الوقف النقدي:

ومع كل هذه المزايا فهناك بعض مخاطر ينطوي عليها وقف

النقود نجملها فيما يلي:

1- عدم تنميتها لم تعد النقود ذهباً وفضة حتى تظل محافظة على لـى

قيمتها الثرائية لثمنيتها الذاتية، بل لقد أصبحت عملة ورقية، اكتسبت قيمتها بالاعتبار، وللحفاظ على بقاء قيمتها الثرائية لا بـ من تحريكها

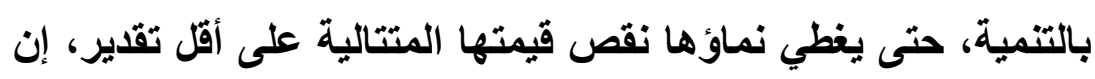
لم يحقق لها نماعً ليزداد نفعها. 
2- تضخمها(1)، والتضخم مصطلح حديث من مفردات المصطلح

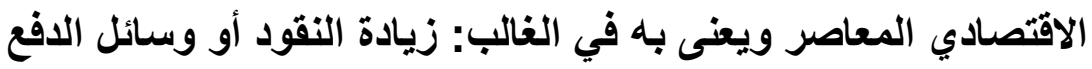

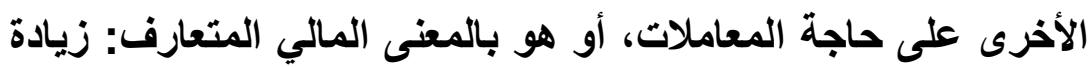

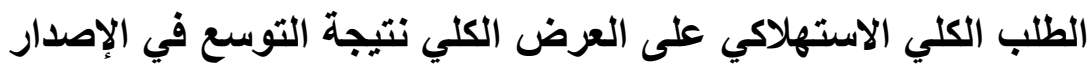

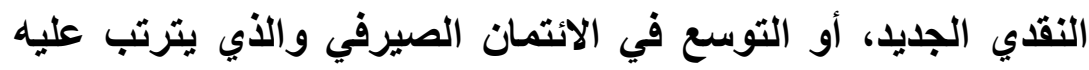

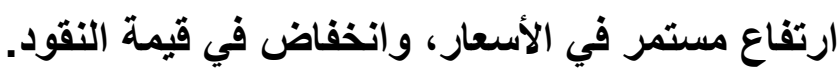
3- عدم تحري الاقة في صرفها: ويعد ذلك تفريطاً من الناظر

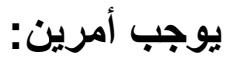

(1) - للتضخم أسباب كثيرة منها: 1- الزيادة في كمية النقود التي تصدرها الجهات النقية لسد المستحقات عليها اللموظفين.

2- الاختلال بين العرض والطلب نتيجة انخفاض الإنتاج أو استقراره مع وجود

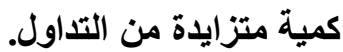
3- ارتفاع الكلف الذي ينتج ارتفاع الأجور بسبب ارتفاع الأسعار وغلاء كلف الفألف

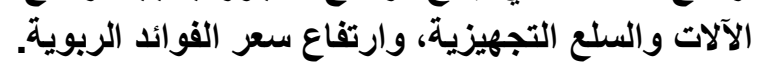

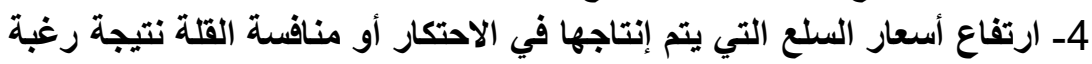

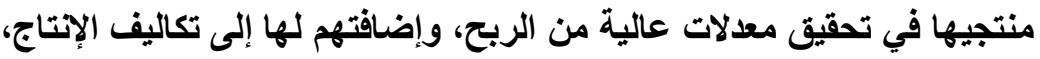

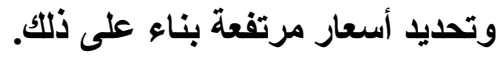
5- ارتفاع معدلات الأجور بما تمارسه نقابات العمات العمال من ضغوط لرفع معدلات

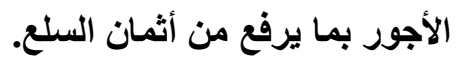
6- ارتفاع أثمان المواد الخام أو المواد الذذائية المستوردة مما يزيد من نفقات الإنتاج.

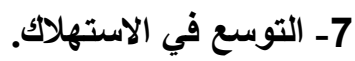
8ـ الفائض النقاي نتيجة وجود فائض في ميزان المدفوعات. 9ـ ا اختلال التوازن بين الاستهلاك و والاستثمار.

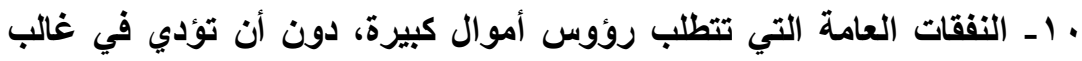
الأحيان إلى أي إنتاج كالمصاريف العكرية. 11- حدوث النكبات العامة من حروب قاسية داخلية أو دولية الوالية أو مجاعات بسبب

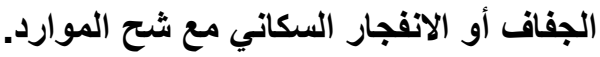

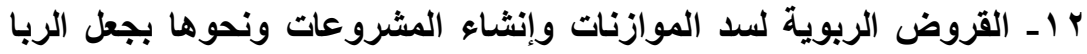
أضعافا مضاعفة. (وقق النقود واستثمار ها للحداد ص 66 6وما بعدها). 
الأول: ضمانه، والثاني: عزله لعدم كفايته؛ ذلك لأنّ صرفه على الوجه الأي شرطه الواقف فرض عليه، فإنّ شرط الواقف كنص

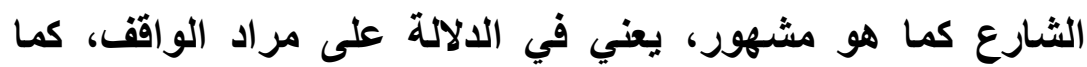

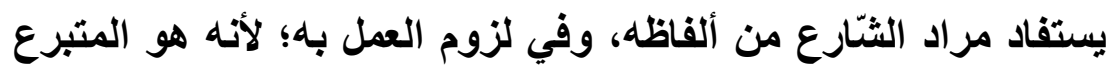

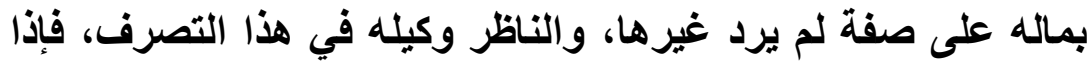
تصرف على غير مراده كان ضامناً كالوكيل وسائر الأمناء إذا فرطوا.

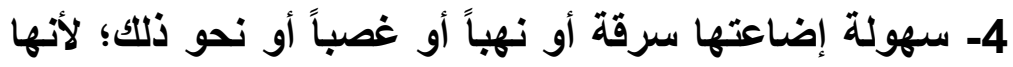
خفيفة الحمل تسهل سرقتها أو نهبها أو اختلاسها أو غصبها، ولعاب اونهاب

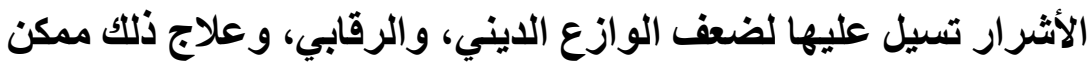

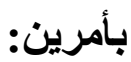

الأول: تربية المهابة في نفوس الناس عموماً بأمر الوقف وخطره؛

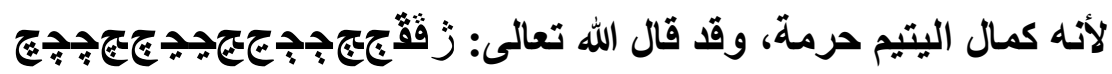

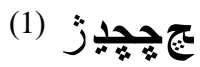

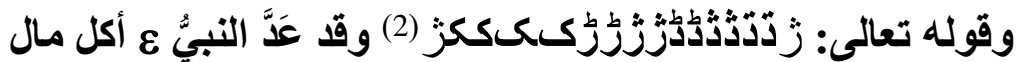

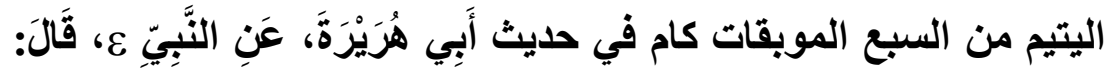

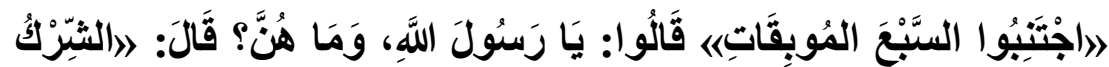

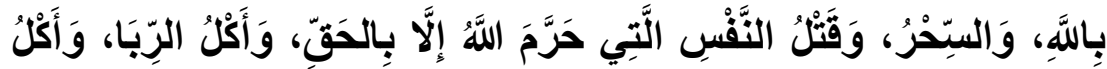

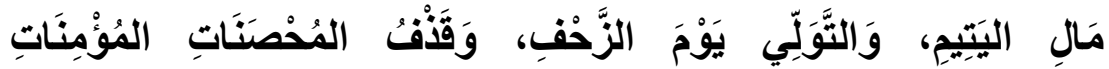

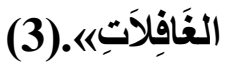
والمويقات هي المهلكات التي توبث صاحبها في الإثم.(4)

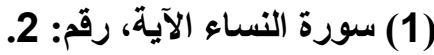

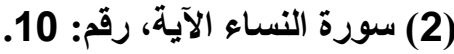

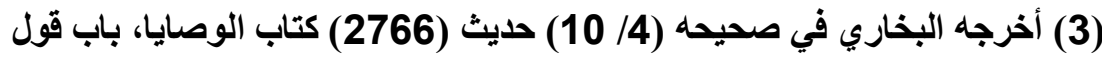

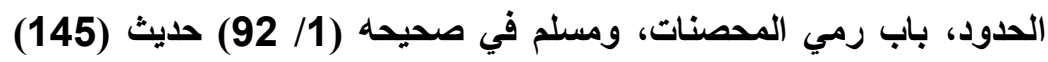

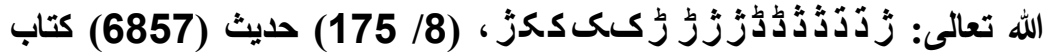

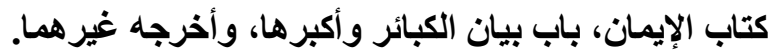

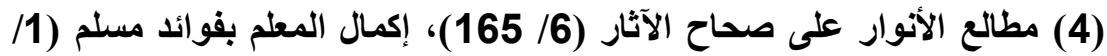


أمّا الأمر الثاني: فبتفعيل الرقابة والحفظ والصيانة لهذا المال، بأن

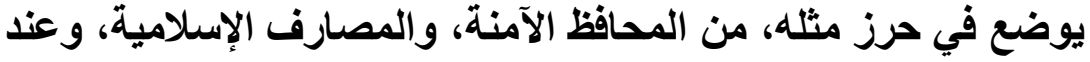
الأيادي الأمينة. ولا يفرط في قليل منه أو كثير، ولا يكون هناك سئك سبيل

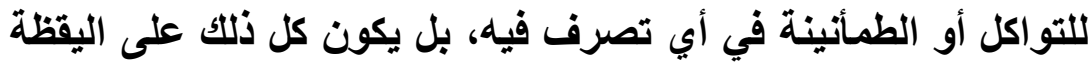
التامة، والتوثق الكامل، فإذا تم كذلك فهو أجدر أن يحفظ، ويبقى مصوناً حتى يصل لمستحقيه. ومن مظاهر الاسترواح وعدم اليقظة في وضع هذا الوقف فئق النقدي: ما يجري في صناديق الوقف الخيري التي توضع في المساجد

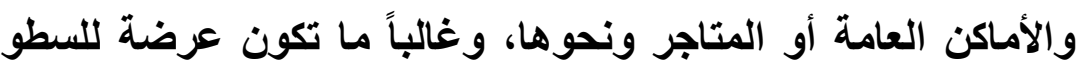

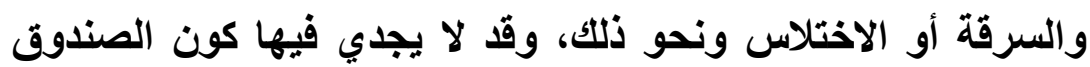

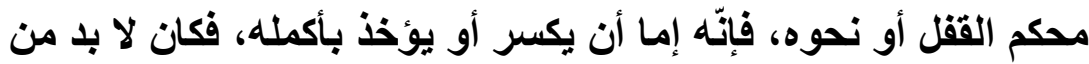

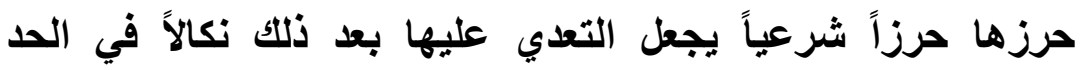

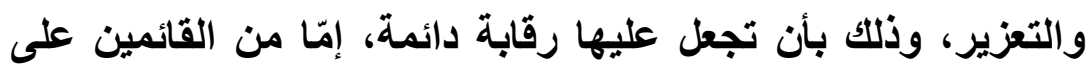

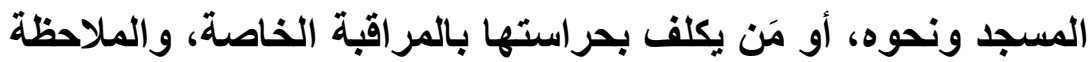

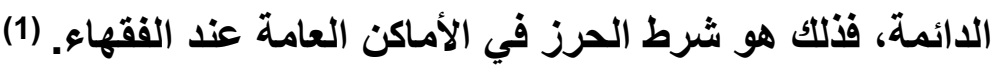

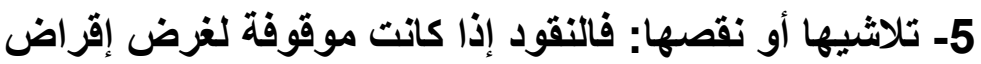

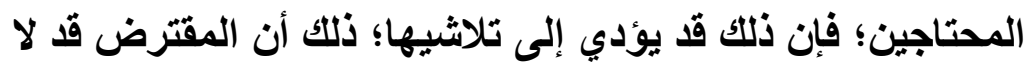
يردها أو لا يرد بعضها و هكذا حتى تتلاشىى. ولكن هناك وسائل يمكن اتخاذها لافع هذه المخاطر، أو أو التقليل منها، وذلك بالقيام بتدابير وقائية للحيلولة دونها، فمن ذلكت أ- أخذ رهن، أو ضامن بذلك.

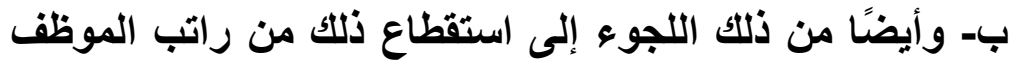
إذا كان المقترض موظفًا، وذلك بالاتفاق معه على شيء مقدر شهريًا

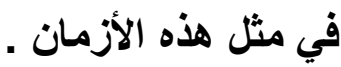

(1) وقف النقود واستثمارها للحداد (ص62) وما بعدها، ويراجع: صناديق الوقق

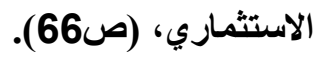


فإن قيل: كيف يقرض إذا كان موظفًا ؟ مع أن الظاهر أن عنده

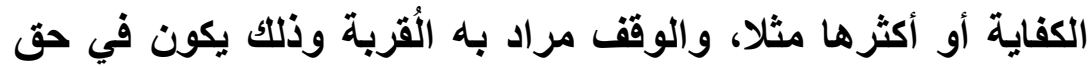
الفقراء ؟ فيجاب عن ذلك أن القرض لمن يكون محتاجًا، فإذا احتاج

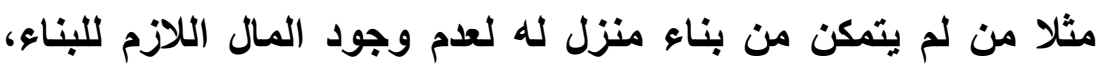

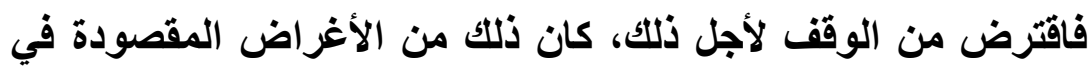
وقف النقود ـ. 6 - إن النقود عرضة لنقص قيمتها أو كسادها في وقت الوفاء.

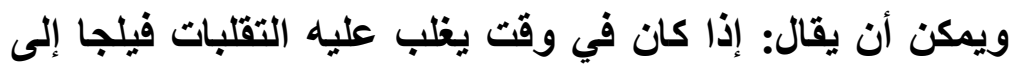

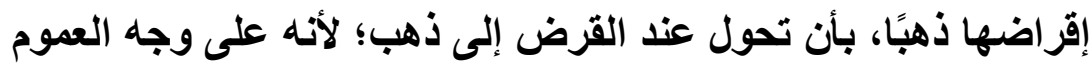

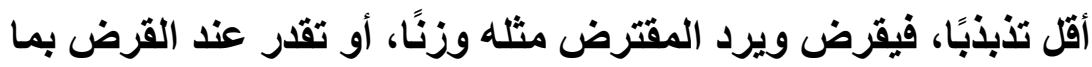

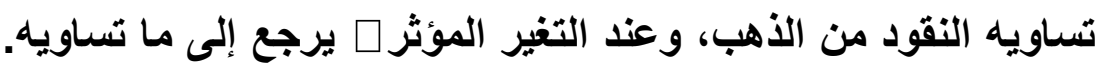

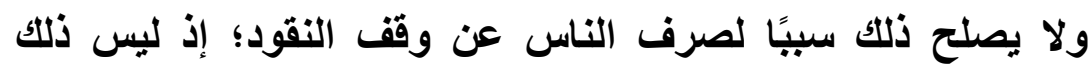

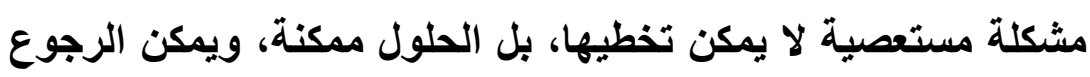

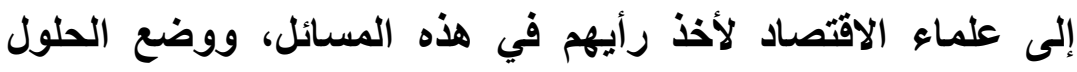
المناسبة لهذه المشكلة .

7 - ومما يعترض وقف النقود في حال ما إذا وقِقِت للمضاربة مثلا: أن ذلك قد يفضي إلى تلاشي الوقف؛ إذ إن إن المضاربة وميع الأخذ

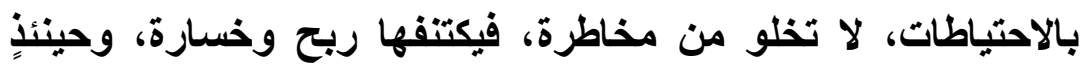
تكون النقود الموقوفة معرضة للاضمحلال؛ إذ قدان تتكرر الخسارة فتتلاشى، هذا إن لم تحصل الخسارة لها كاملة من أول مرة .

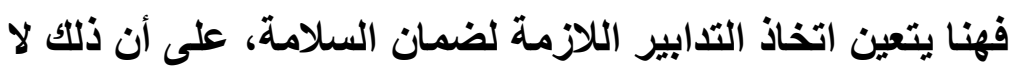

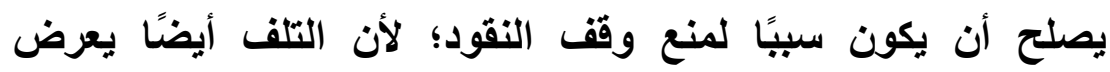
للحيوان الموقوف وللثجرة الموقوفة، ولم يكن ذلك مانعًا من صحة

وقفها. (1)

$* * * * *$ 


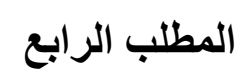

أنواع وقف النقود

رغم أنّ مسألة وقف النقود كانت مطروحة في الفقه الإسلامي منذ

قرون عديدة، إلا أنّها لم تكن بهذا الثيوع، ولم يبلغ مجال الاستثمار فيها الحال الذي بلغه اليوم؛ بسبب تطوّر مجالات الاستثمار وأشكاله ومؤسسّاته وأساليب تنظيمه بفعل التطوّر الاقتصادي العام في العالم. لقد كان وقف النقد موجوداً بشكل ضعيف في الأزمنة السالفة.

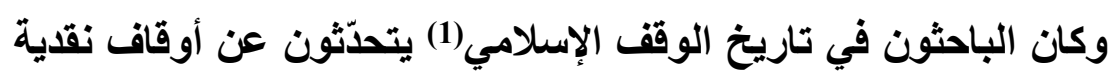
للإقراض أو الاستثمار والمضاربة بشكل بسيط. وقد نقل الته البخاري سؤالاً

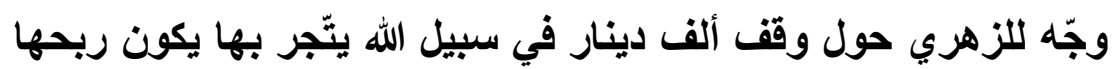

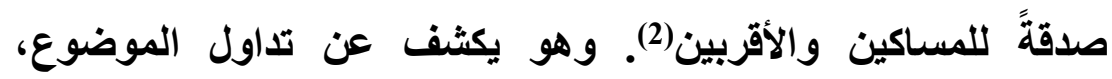
وموافقة الزهري عليه في أوائل القرن الثاني الهجري. كما ورد في ولئ

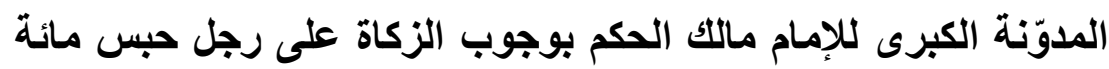
دينار موقوفة يسلفها الناس ويردّونها على ذلك الذي جعله مالكا حبساً). ومثل ذلك من استفتاءات منقولة عن الإمام أحمد بن حنبل.

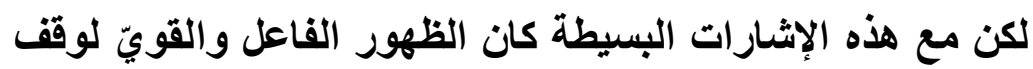
النقود في بدايات العصر العثماني(4)، حيث كان في بعض بلإندان البلقان(5)،

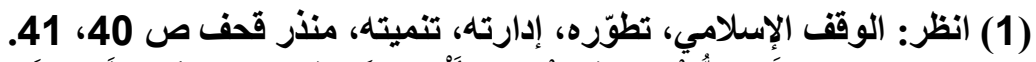

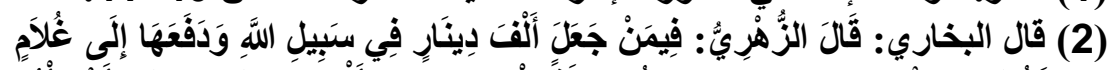

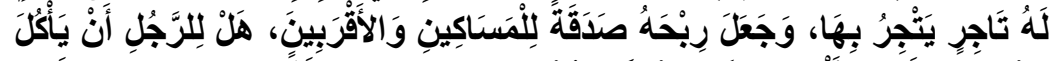

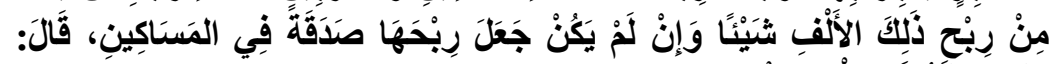

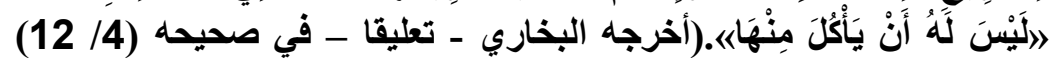

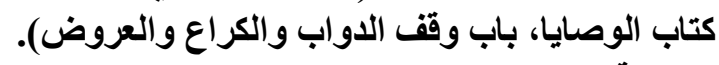

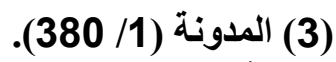

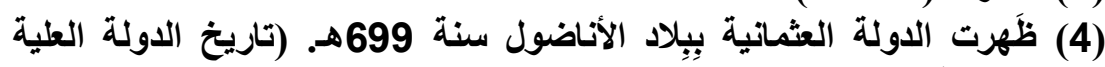

العثمانية (ص: 85)

(5) البلقان: هي شبه جزيرة تحاط بان بستة بحار، تبلغ المساحة الكلية لمنطقة البلقان

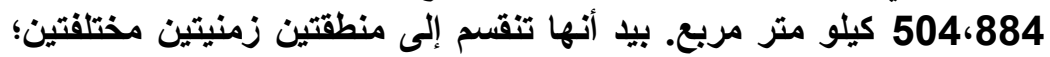

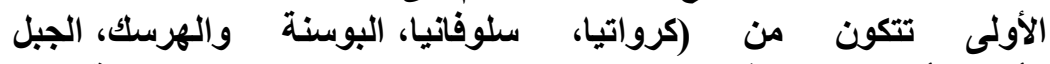

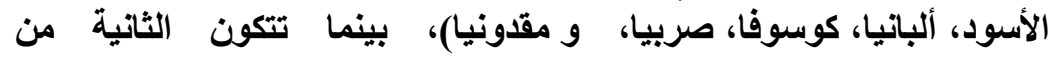


ثم انتقل إلى استانبول بعد فتحها، ومنه إلى بلاد الثام، ثم تحوّل إلى

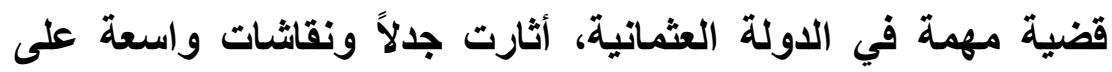

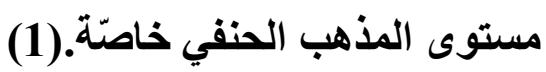

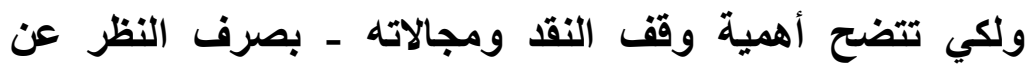
شرعيّته - يمكن ذكر بعض صور الوقف النقاي التي باتت ممكنةً أو

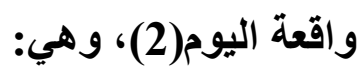
1- الوقف النقاي الاستثماري: ويقصد به وقف مبالغ ماليّة معينة،

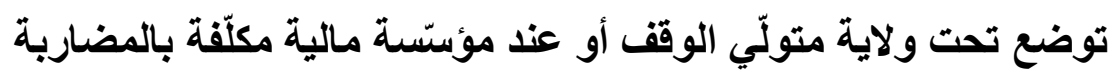

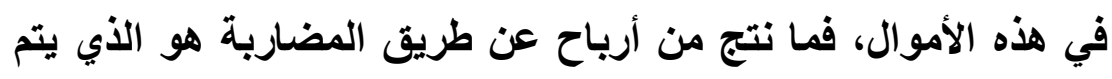
توزيعه على مصارف الوقف المقصودة للو اقف. ولا فرق في في في ذلك الك بين:

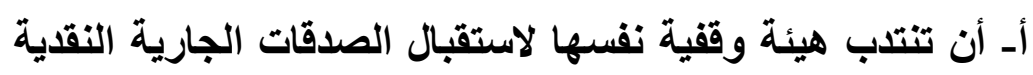

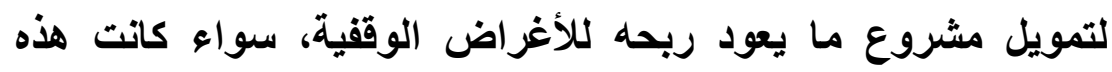

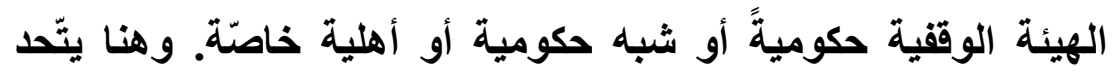
الناظر على الوقف مع المستثمر له.

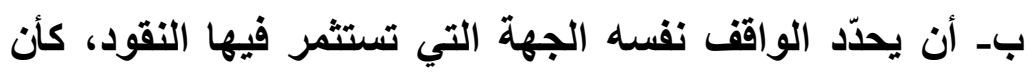

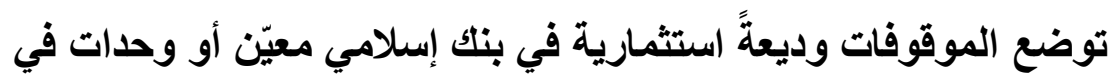

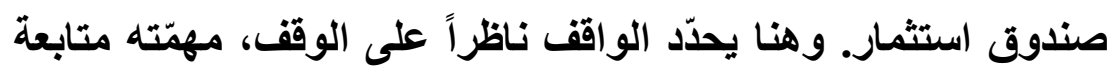

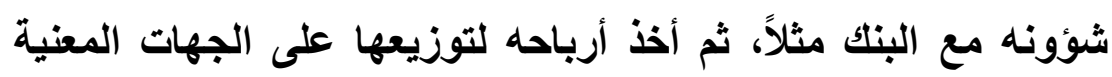

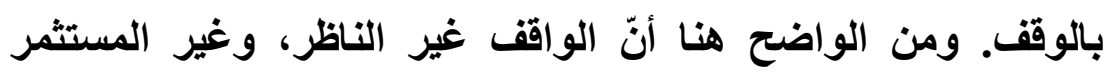
أيضاً.

(اليونان، بلغاريا، رومانيا،و تركيا).وكييديا،الموسوعة/الحرة: https://ar.wikipedia.org/wiki

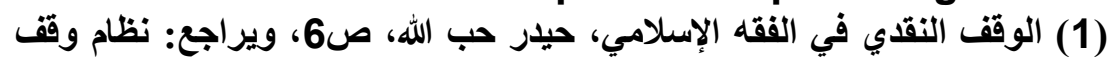

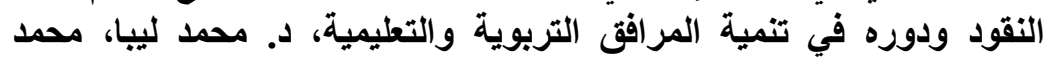

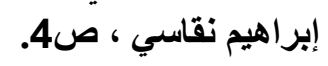

(2) تعرّض الكثيرون للحديث عن أشكال الوقف النقدي، ولكن نكتفي من باب المثال

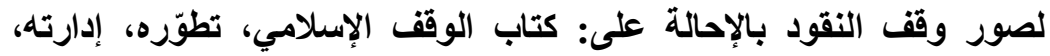
تنميته، لمنذر قحف: ص: 193 - 210. 
ج - أن يصار إلى جمع أموال وققية بغية تحويلها إلى أعيان، كبناء

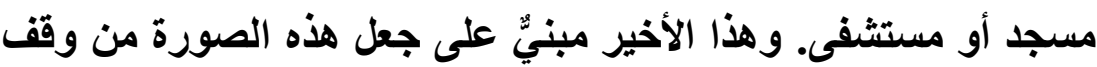

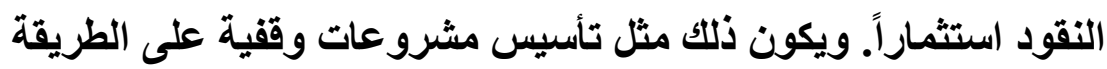
السودانية، أو صناديق وققية على الطريقة الكويتية؛ بهدف استدراج التبرّعات الوقفية لمشروع معيّن أو غير معيّن بمغنى غير مفرد الهدف.

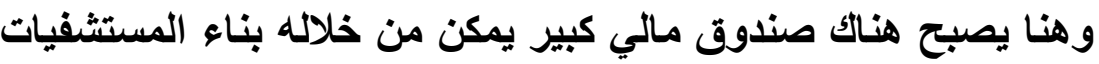
أو المساجد أو المستوصفات أو المدارس أو الجامعات أو المعاهد

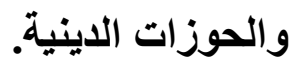

كما يمكن أن يكون الوقف بإصدار أسهم نقدية وققية؛ تثنجيعاً على الوقف لتحقيق المشاركة الجماعية فيه.

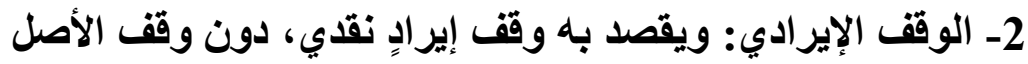

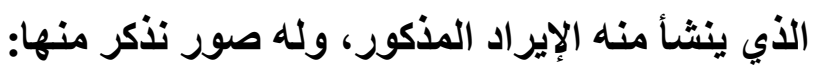

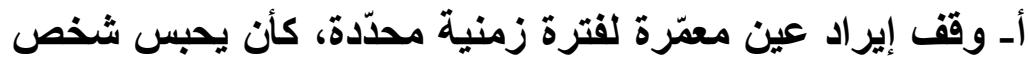

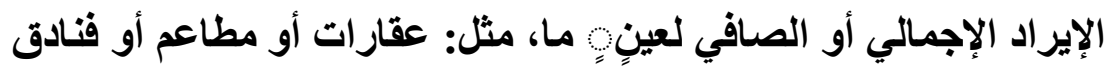

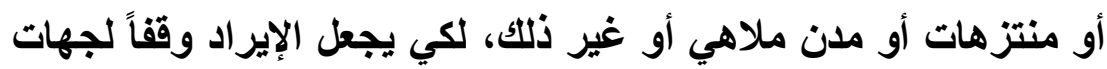
البرّ. ولهذه الحالة صور، فتارةً يكون الوقف مؤبِّاً؛ وأخرى يحدّد شهراً في السنة يجعل إيراده وقفاً، بناء على صحّة ذلكّة بـ وقف حصّة محسومة بنسبة مئوية من الإيرادات النقاية لصالح

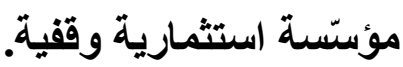
3- الوقف النقدي القرضي: ونقصد به أن توقف النقود لإقراضها

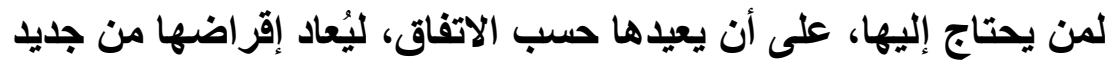

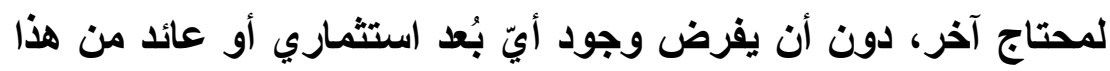

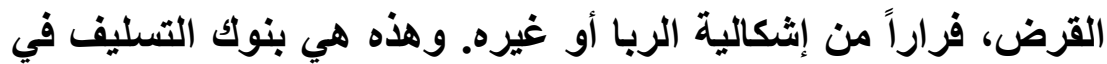

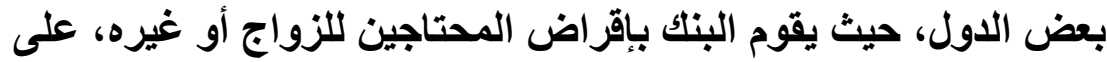
أن يسدّدوها بأقساط خفيفة على دفعات كثيرة، ويمكن تسميتها ببنوك التسليف الوققية، وهذا هو الوقف للسلف. 
إلى غير ذلك من الصور التي اقترحت أو يمكن تصويرها، مثل: وقف احتياط الثركات المساهمة، وغير ذلك.

$* * * * *$ 


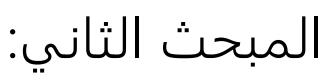

الحكم الشرعي لوقف النقود، وبعض المسائل المانل

المتعلقة بوقفها.

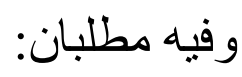

المطلب الأول: الحكم الشرعي لوقف النقود.

المطلب الثاني: أثر تغير قيمة التقد على قيمة الأصول

النقدية الموقوفة.

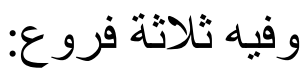

الفرع الأول: مصادر تحديد قيمة الأوراق النقدية.

الفرع الثاني: أثر تغير قيمة النقد على قيمة الأصول النقدية

الموقوفة.

الفرع الثالث: حكم تحديد مخصصات لمواجهة تغير قيمة

النقد. 


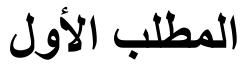

الحكم الثرعي لوقف النقود

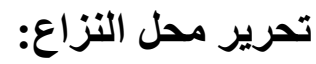

ليست النقود من الأصول الثابتة، بل هي من الأصول المتداولة

المنقولة، وهي من الأموال المثلية التي تقترض، كما أنها ليست من الأنه الأموال التي تعار وتستأجر؛ لأنها تستهلك دفعة واحدة، ومن ثم فإنها

تتلف بالاستعمال، فهل يجوز حينئ وقف النقود؟ أجمع العلماء على مشروعية وقف العقار(1) من أرض وبناء(2)، واختلفوا فيما عدا ذلك. اختلف العلماء في صحة وقف النقود من الاراهم والانانير، وكل عين تكون منفتها باستهلاكها على خمسة آراء:

(1) العقار هو: غير المنقول ما لا يمكن نقله من محل إلى آخر كالاور والأراضي

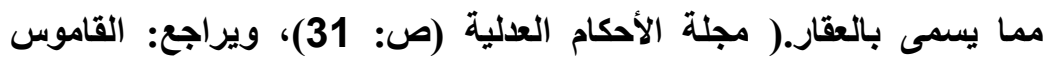

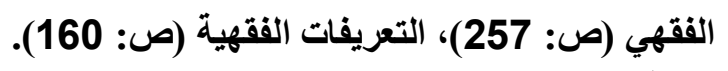

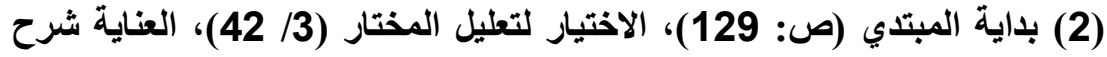

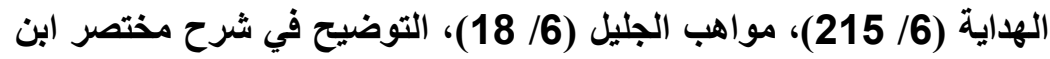

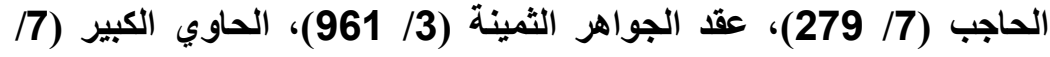

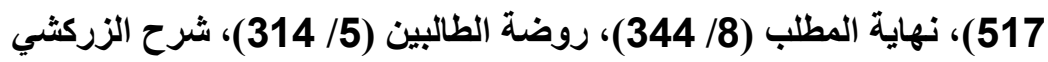

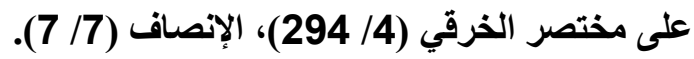

قال الترمذي في سنته (3/ 652):" العمل على هذا عند العند أهل العلم من أصحاب

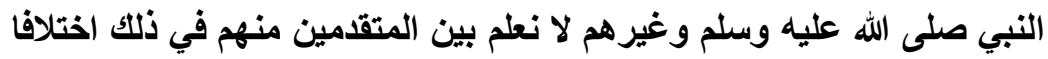

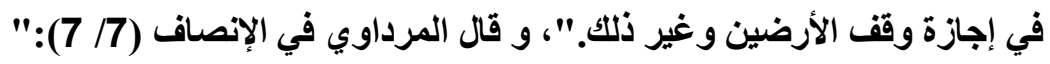
وقف غير المنقول: فيصح بلانزاع." 
الرأي الأول: لا يصح وقف النقود، وهو ما ذهب إليه أبو حنيفة

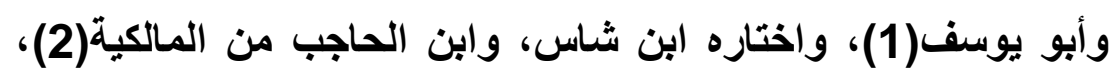

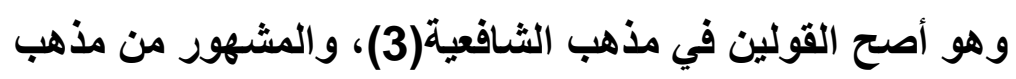

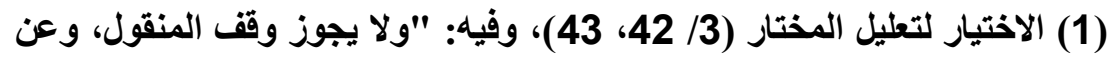

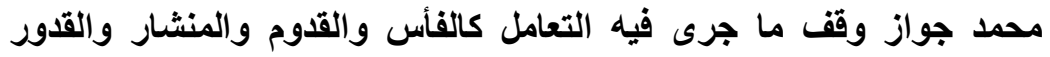

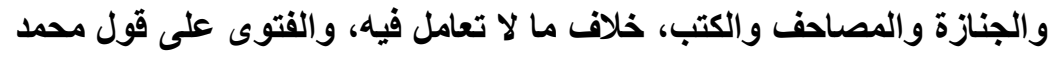

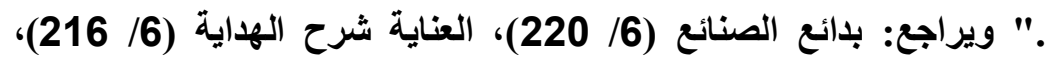

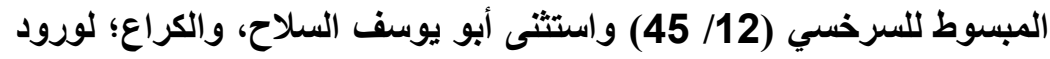

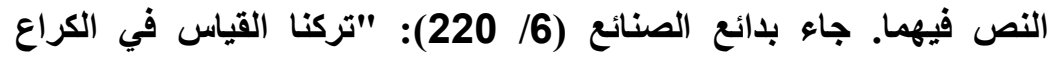

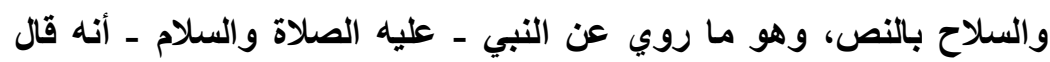

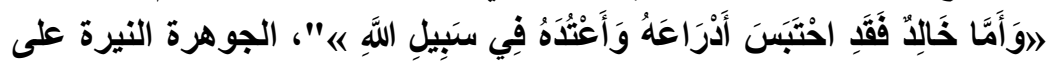

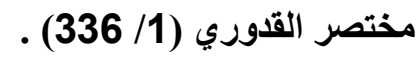

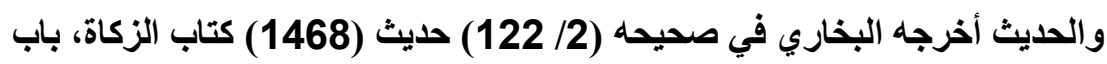

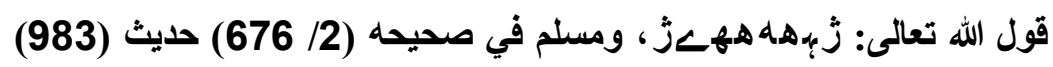

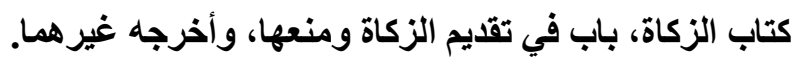

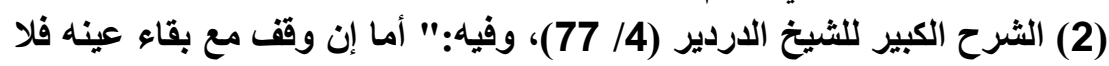

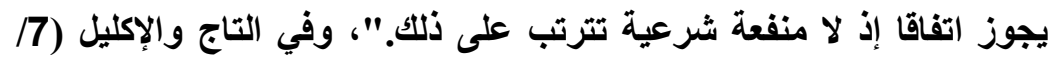

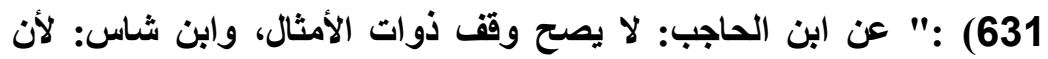

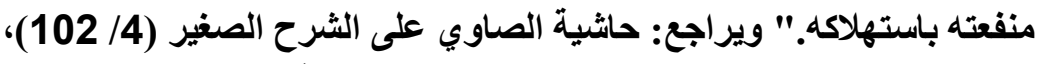

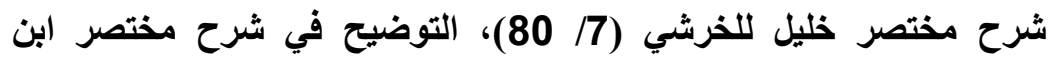

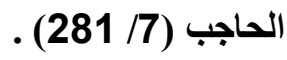

(3) الوسيط في الدذهب (4/ 239، 241)، وفيه: "وشرطه أن يكون مملوكا معينا

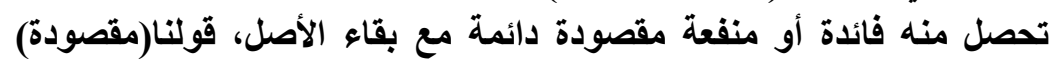

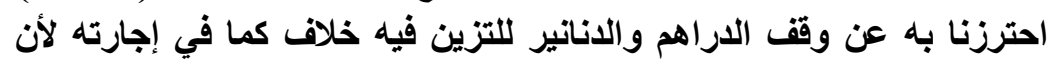

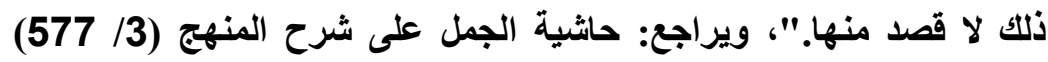

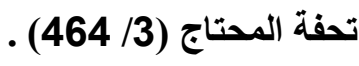


الحنابلة(1)، و الظاهرية(2)، والإباضية(3)، والزيدية(4)، وهو الظاهر عند الإمامية(5)، حيث منعوا جميعا من وقف المنقول. واستدلو ا علي ذلك بالسنة، والمعقول:

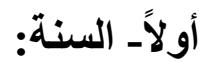

ويستدل من السنة بالأحاديث التي فسرت معنى الوقف وبينته،

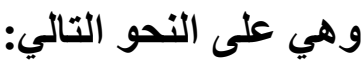

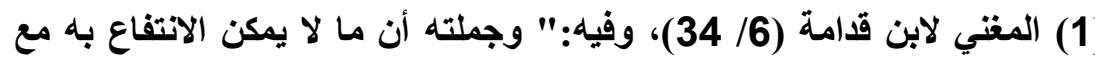

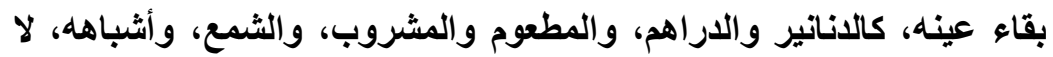

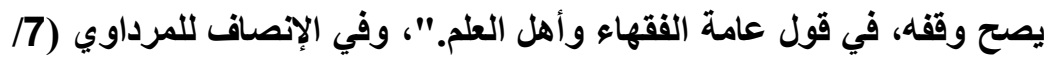

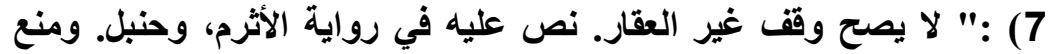

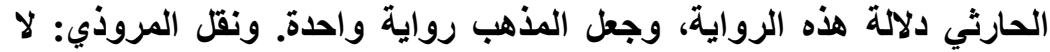

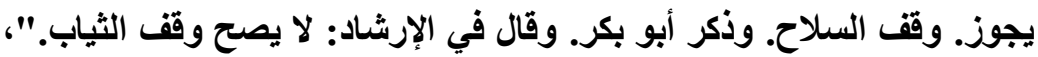

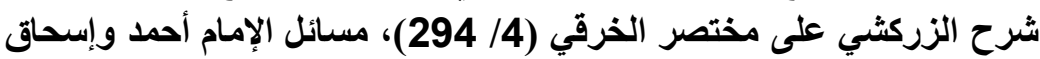

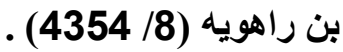

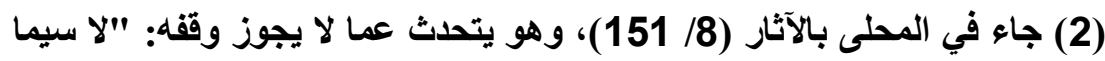

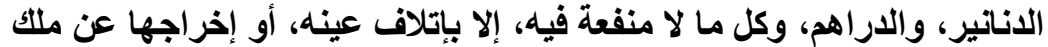

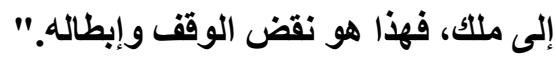

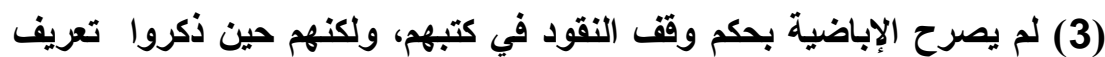

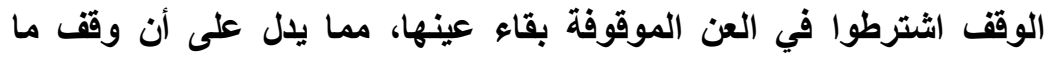

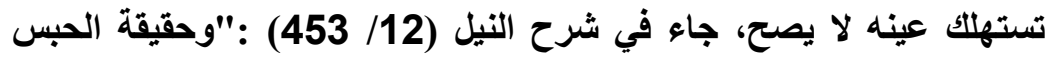

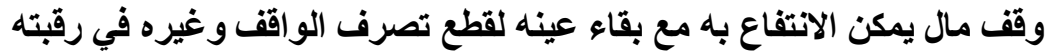

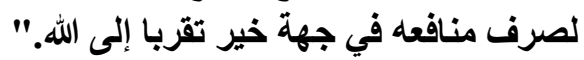

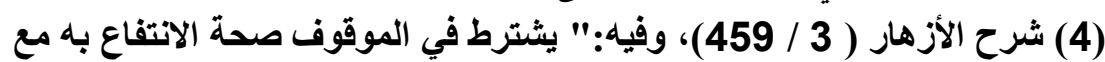

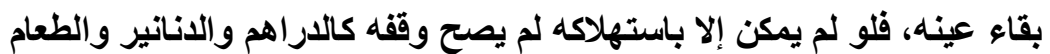
ونحو ذلك."، ويراجع: السيل الجرار المتدفق على حدائق الأزهار (ص:

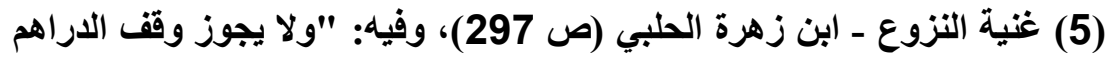

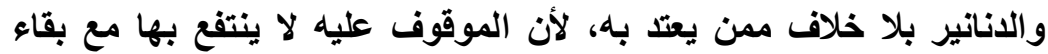

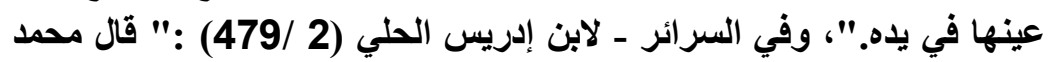

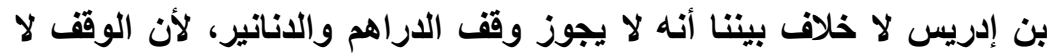

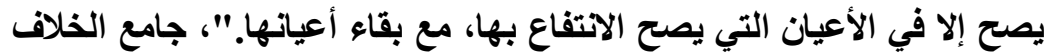

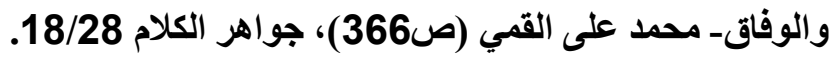




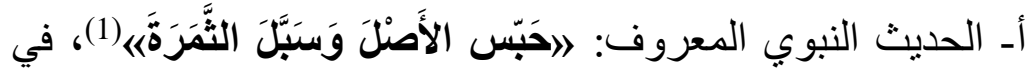
جوابه لعمر ابن الخطاب ح حين قال له: إيا رسول الله، إني أصبت مالاً

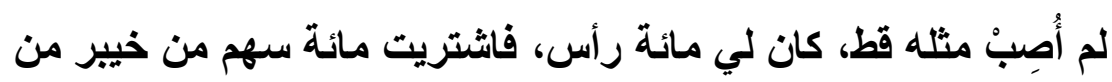

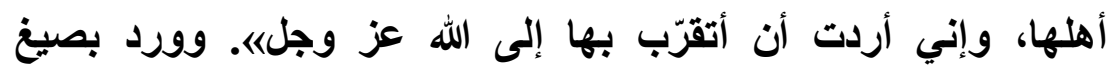

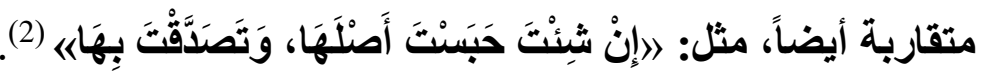

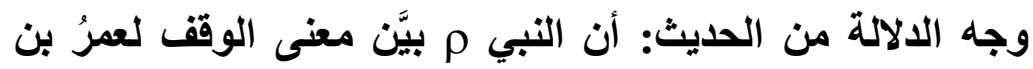

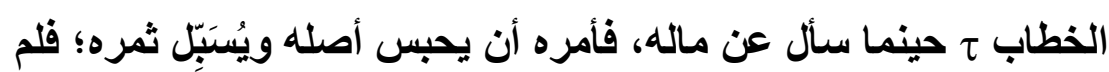

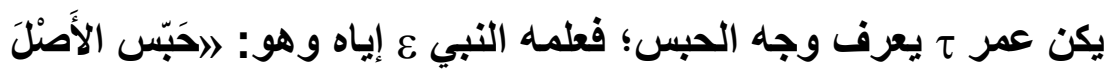

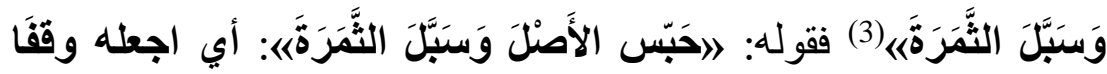

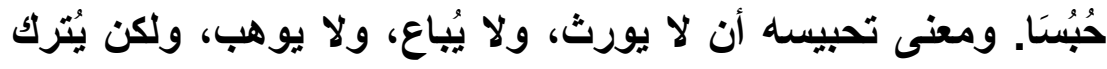

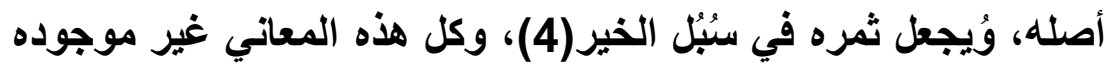
في وقف النقود؛ لكونها تستهلك بالاستعمال. ونوقش الاستدلال بهذا الحديث: بأن هذا الحديث الأي اعتُر الأصل في تحديد هويّة الوقف غير دالّ على حصر هذه الهويّة بما جاء

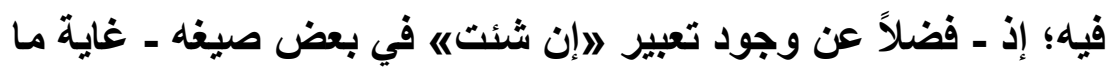

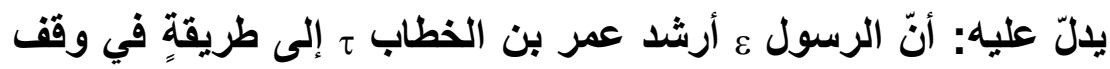

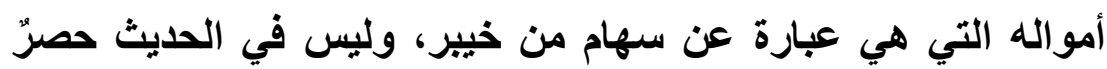
للوقف في هذه الطريقة، وربما لو كاتت أموال ابن الخطاب دراهم

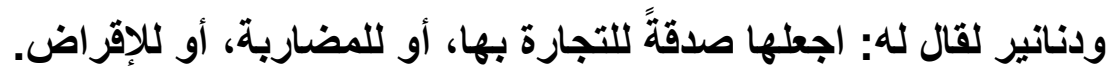
بل ما المانع أن يكون الوقف على نوعين: أحدها يشتمل على تحبيس الأصل؛ والثاني لا يشتمل عليه، ويكون الرسول ع قل أرشده إلى إحدى نائ

(1) سبق تخريجه عند شرح تعريف الوقف عند الإمامية. (2) سبق تخريجه عند شرح تعريف الوقف عند عند الإمامية.

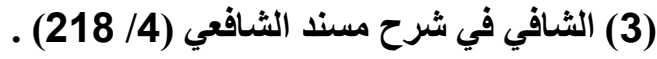
(4) ذخيرة العقبى في شرح المجتبى (30/ 43 (218) . 
الطريقتين؟! نعم لا يسمّي الفقهاء النوع الثاني وقفاً، وإنما يعبّرون عنه بأنه صدقة، ولا ضير مادام الوقف في لسان النصوص الدينية غير مستخدم كثيراً، وإنما المستخدم هو الصدقة، ومنها الصدقة الجارية. إضافةً إلى ذلك كلّه، فإنّ هذا الحديث لا يعارض صورة الوقف النقدي؛ لأنّ المفروض أنّه قد جرى تحبيس الأصل وتسبيل المنفعة، غايته أنّ لهّ الأصل هو المالية، وليس في هذا الحديث منعٌ لكون الأصل من نوع

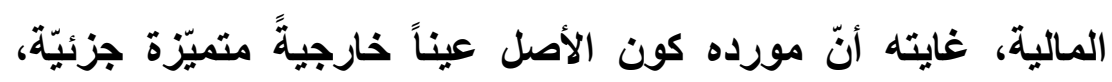

والمورد هنا لا يحرز تخصيصه للوارد الذي ورد بلسان عام. (1) ب - عَنْ نَافعِ، عَنِ ابْنِ عُمَرَ - رَضِيَ الَّهُ عَنْهُهَا - أَنَّ عُعَرَ

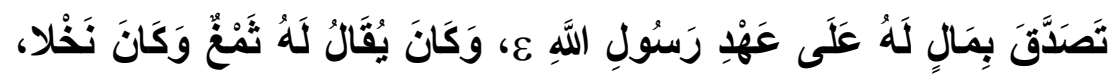

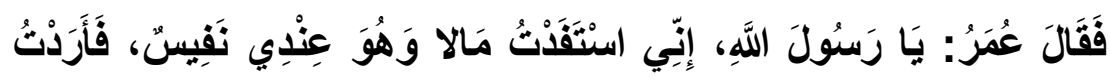

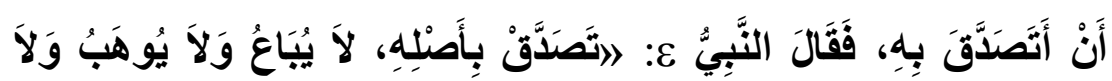

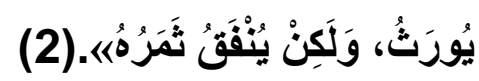

وجه الدلالة من الحديث: دَلَّ هذا الحديث على أن الذي لا يباع ولا يوهب ولا يورث إنما هو الوقف، فِإذا صرّح بذلك فقد دل على أنه قصد بها صدقة الأوقاف،وأنه أراد تحبيسها وإيقافها، فيحكم بوقفها، وأنه أخرجه من ملكه حتى ينتفع با(3)،وهذه الأوصاف لا تتحقق في وقف النق. ونوقش الاستدلال بهذا الحديث: بأن غاية ما يدلّ عليه هو تحقّق

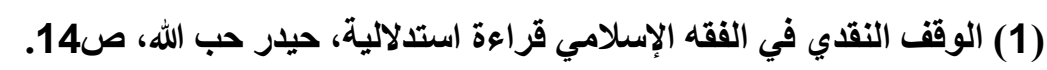

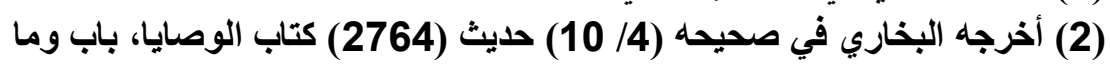

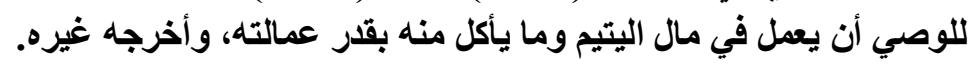
(3) أسنى المطالب في شرح روض ان مال الطالب (253/2/45)، 462)، الكافي في فقه الإمام أحمد فئه

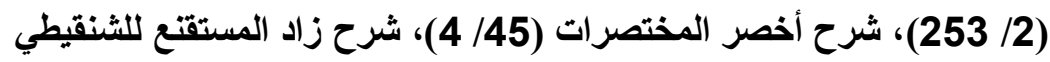


الوقف بهذه الطريقة، لا حصره فيها، ما لم يكن التوصيف ":لا تباع

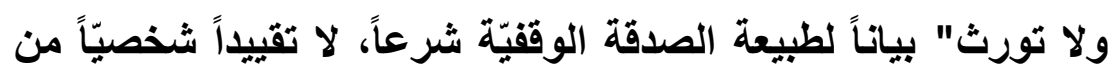

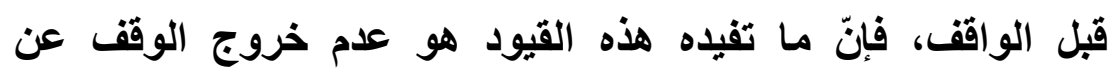

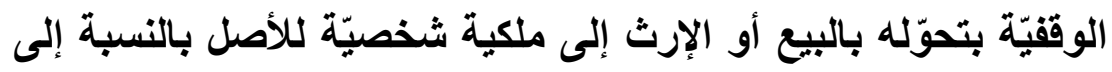

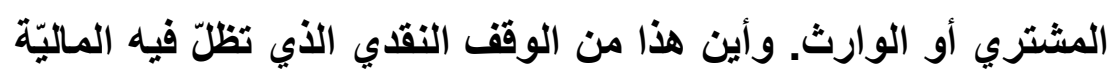

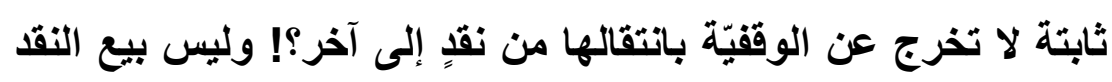

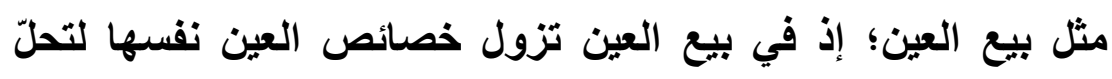

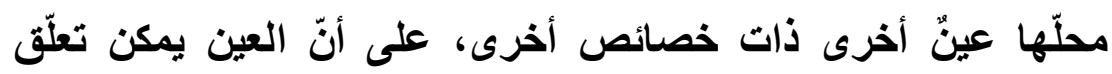

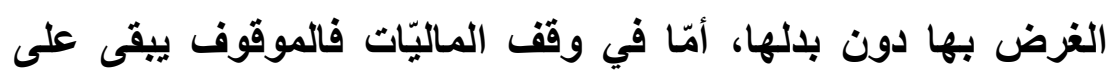

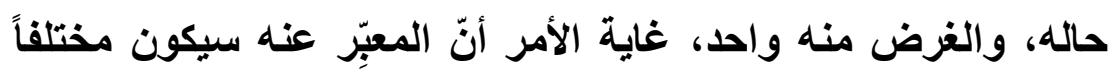

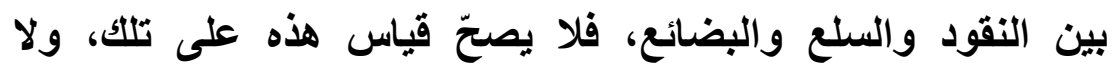

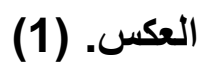

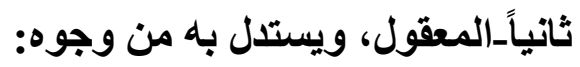

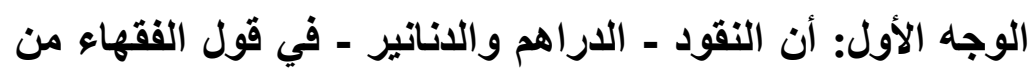

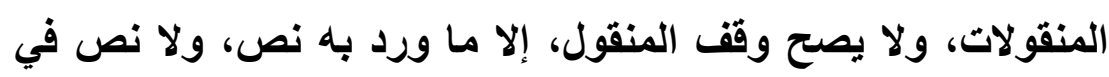

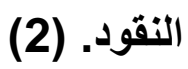

(1) الوقت النقدي في الفقه الإسلامي قراعة استدلالية، حيدر حب الله، ص18.

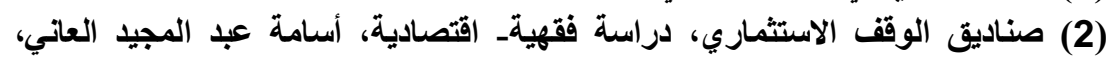

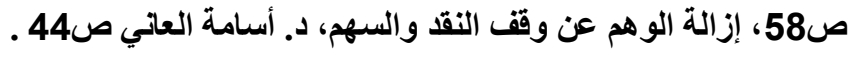


ونوقش هذا الاستدلال: بأنتا لا نسلم بمنع وقف المنقول، بل الصحيح

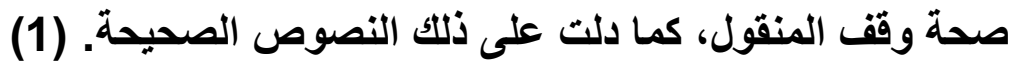
الوجه الثاني: أن من شروط صحة الوقف: التأبيد(2)، والتأبيد لا لا يكون إلا في العقار، والنقود كسائر المنقولات لا تثأبد، ولا تدوم؛

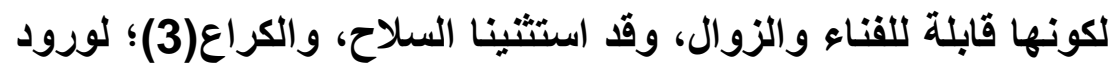

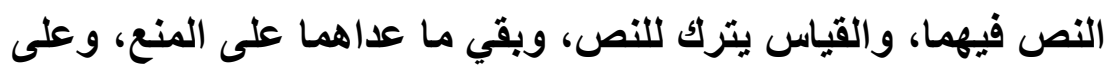

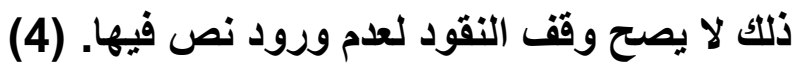
قال أحمد بن حنبل: لا أعرف الوقف في المال إنما الوقف في الاور والأرضين على ما أوقف أصحاب التبي ع ع. قال: ولا أعرف وقف المال ألبتة.

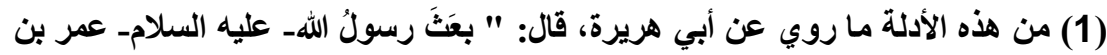

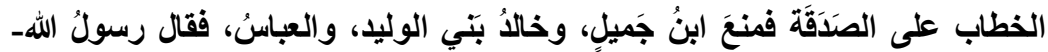

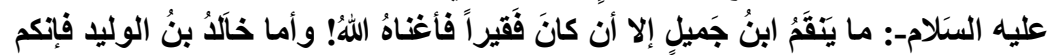

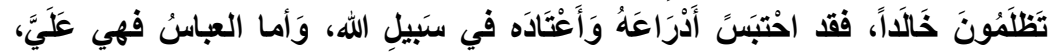

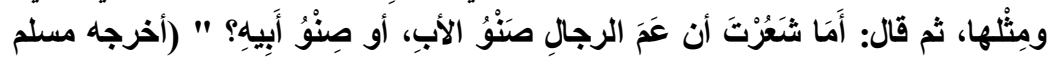

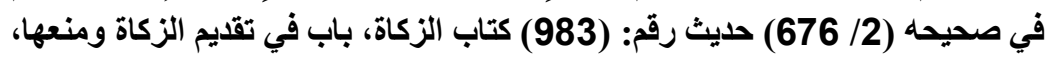
وأخرجه غيره).

وقوله ع : "صنَوُ أبيه" أراد أن أصله وأصل أبيه واحد. وقال ابن الأعرابي: الصنو: المثل،

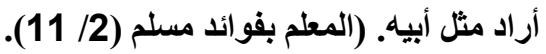
قال النووي في شرح النووي على مسلم (7/7 5 ) معلقا على هذا الحديث:" فيه دليل على صحة

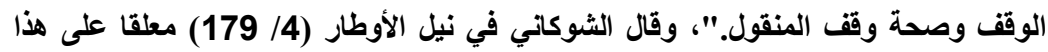

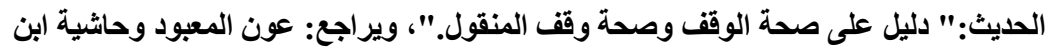

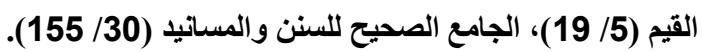

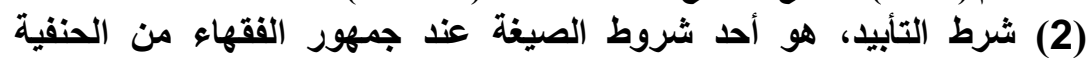

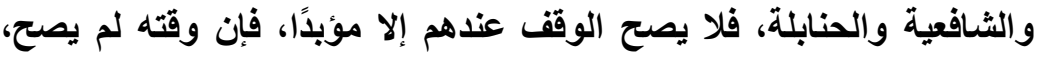

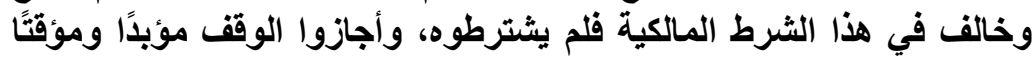

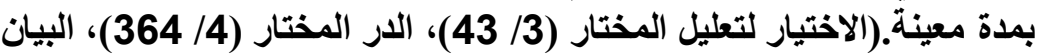

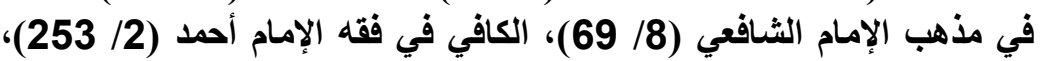

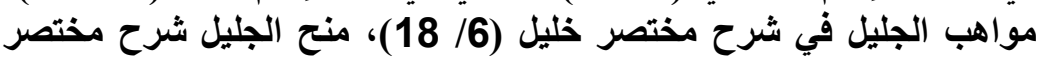
خليل (8/ 108).

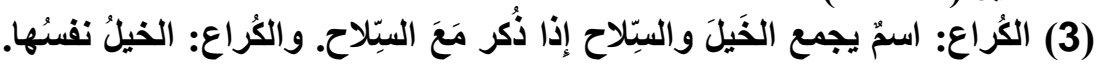

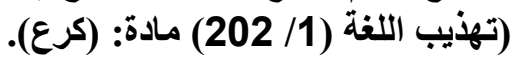

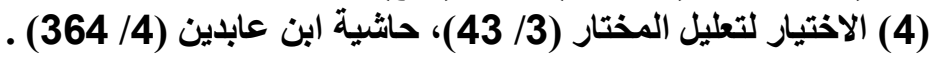


وقال أيضا: لا أعرف حبس المال ولا وقفه إنما يوقف ويحبس الأرضون والسلاح والكراع وما أشبهه، فأما المال فلا أعرفه ولا لاعلا

سمعته. (1)

ونوقش الاستدلال بهذا الدليل: بأن اشتراط التأبيد في وقف العقار لا

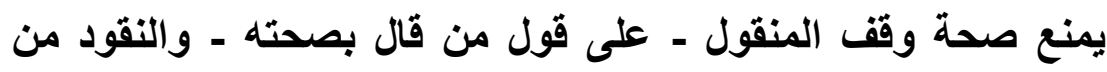

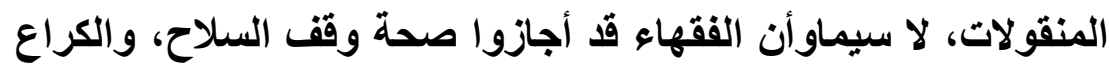
في سبيل الله، فيقاس عليها غيرها من سائر المنقولات، ومنها النقود. وعلى فرض أن التأبيد شرط في صحة الوقف، فإن محمد بن فئن

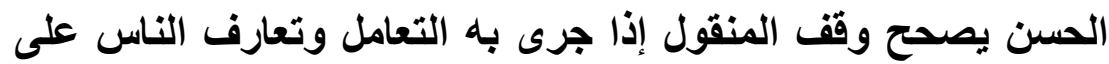

وقفه، كما قالكه في السلاح و الكراع(1). قال ابن عابدين: "لا يخفى عليك أن المفتي به الذي عليه الديه المتون جواز وقف المنقول المتعارف"(2).

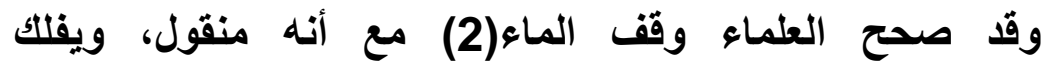
بالاستهلاك، فالنقود مثله، بل أولى، فإن النقود مال بالأصالة، والماء

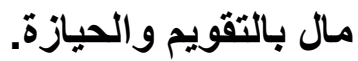

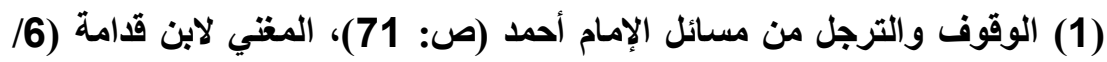

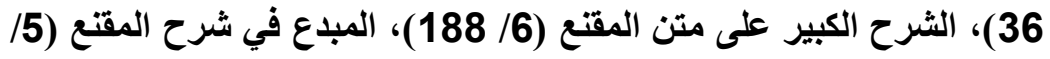
.(154

(2) قال الفضل: سألت أحمد عن وقف الماء، فقال: إن كان شيئا استجازوه بينهم

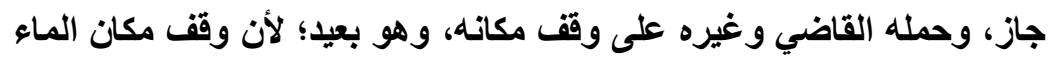

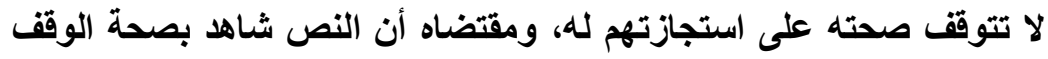

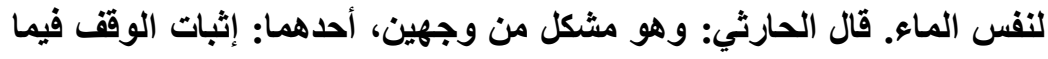

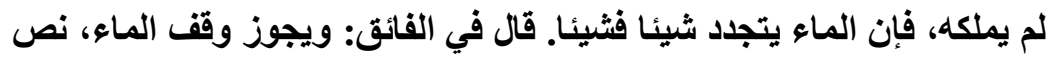

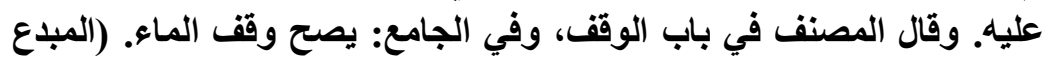

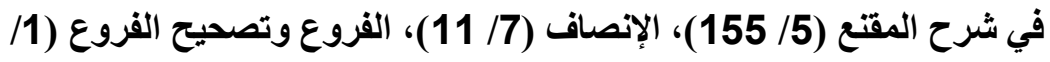

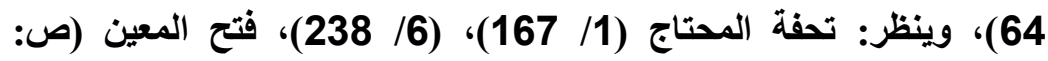

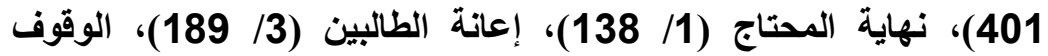
والترجل (ص: 60)، مطالب أولي النهى (138، 279) 
ورد على هذا: بأن العرف معتبر في الموضع، أو الزمان الذي

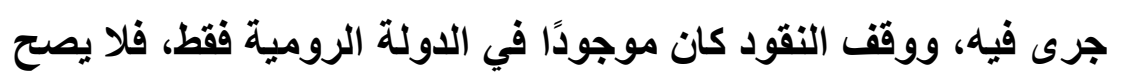

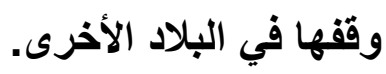

قال ابن عابدين: "الظاهر اعتبار العرف في الموضع أو الزمان

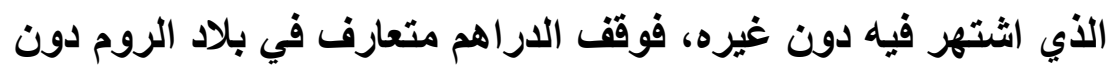

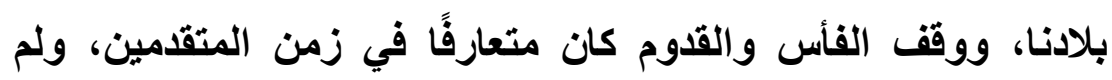

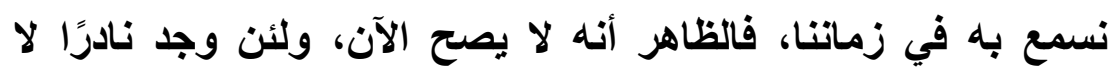

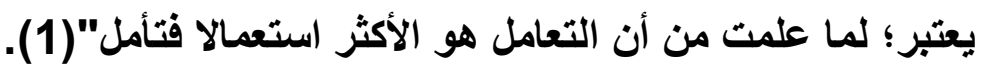

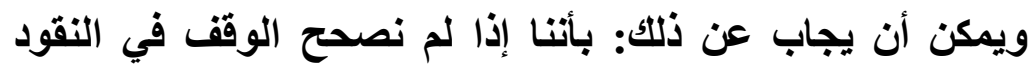

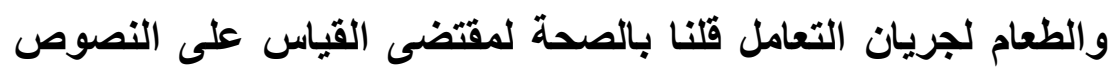

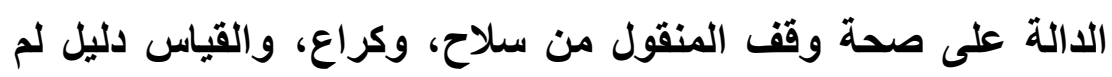

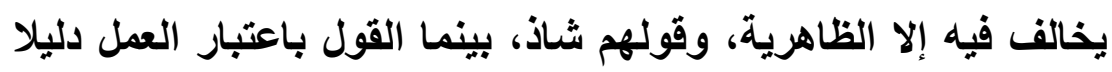

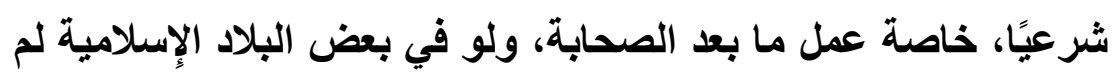

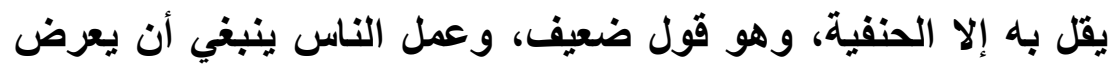

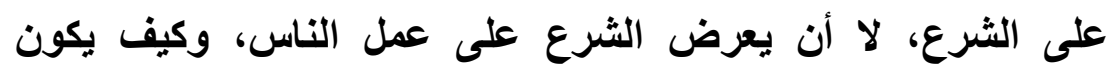

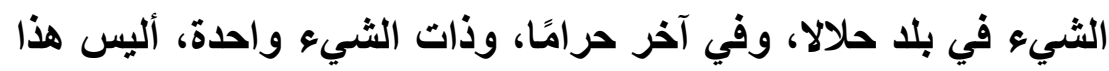

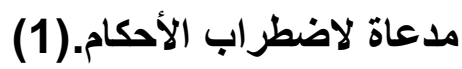

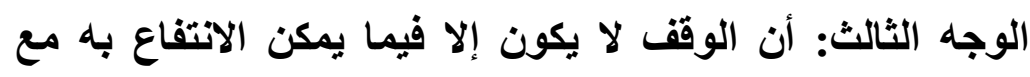

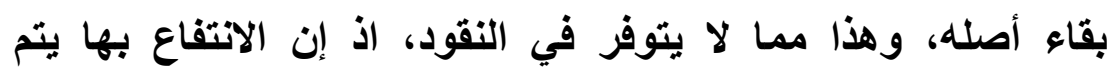

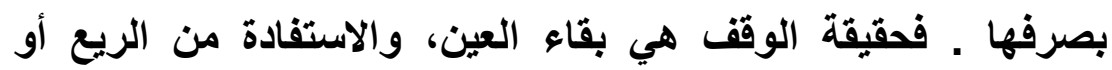

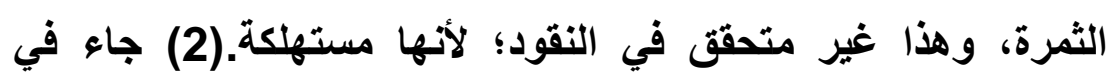

(1) المعاملات المالية أصالة ومعاصرة د. دبيان الدبيان (16/ 190) .

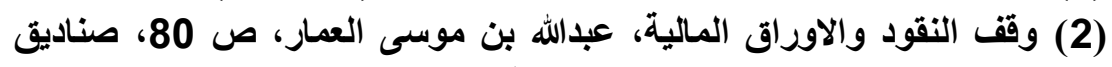

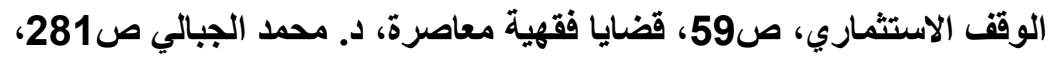

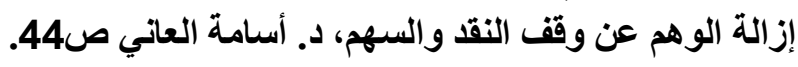


العناية: "احتراز عن الدراهم والدنانير فإن الانتفاع الذي خلقت الدراهم

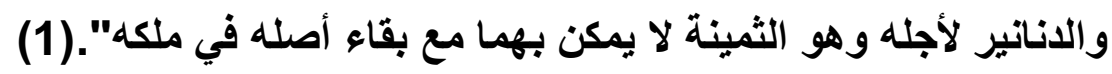
ونوقش هذا الاستدلال من وجوه:

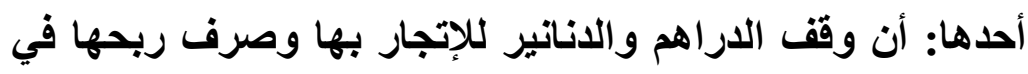

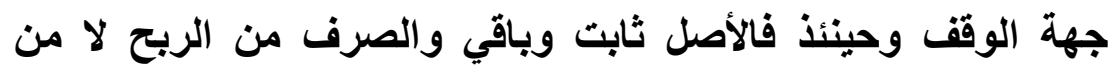

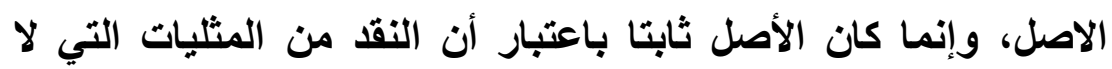

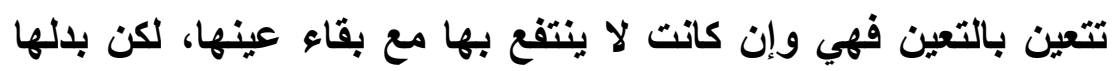

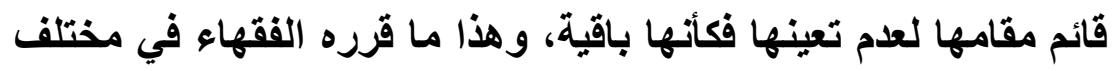

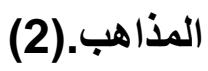

ثانيها: أن النقود مثلية فيرد بلالها، ورد البدل جائز كما هو معلوم

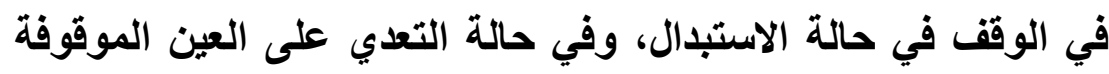

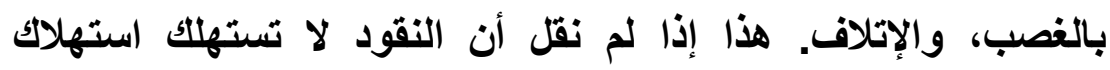

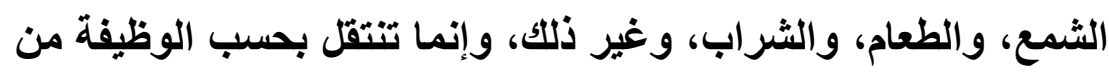

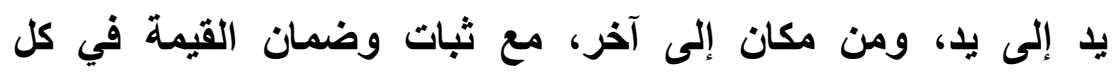

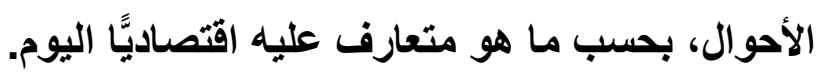

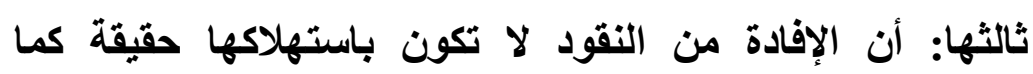

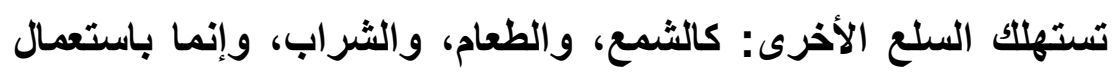

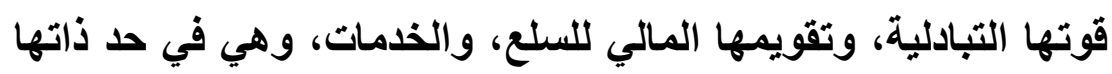

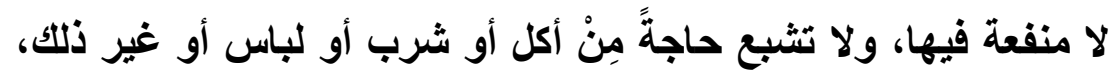

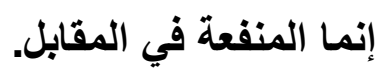

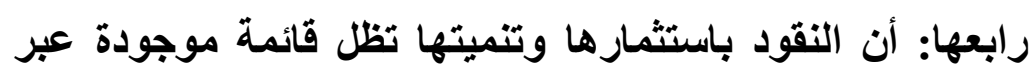
الزمن، ربما بدرجة أكبر من دوام الأراضي، والعقارات، والعبرة

$$
\text { (1) (العناية شرح الهاية (6/ 218). }
$$

(2) وقف النقود والاوراق المالية، عبالله بن موسى العمار ص 80، صنادي صناديق

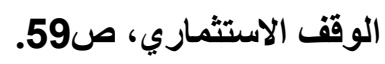


بالإدارة، وليس بنوعية المال الموقوف، وسوء الإدارة يزيل الجميع لا

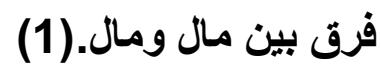

الوجه الرابع: أن الوقف هو تحبيس الأصل وتسبيل المنفعة،

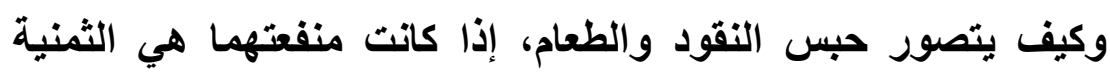
والأكل، وهاتان المنفعتان لا يمكن تحصيلهما إلا باستهلاك أصلهما.

قال ابن قامة: "ولا يصح وقف ما لا ينتفع به مع بقاء عينه

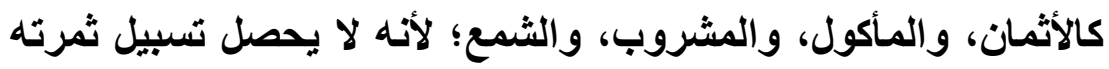

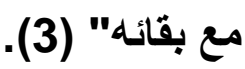
وقال أيضًا: "أن ما لا يمكن الانتفاع به مع بقاء عينه، كالانانير،

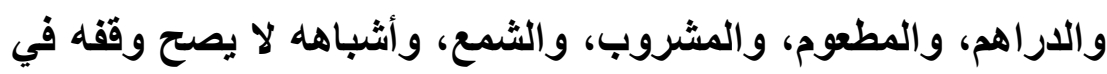

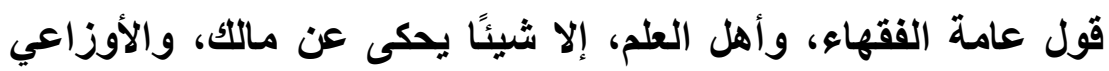

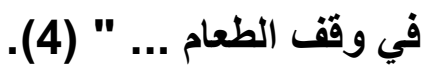
ونوقش هذا الاستدلال: بأن وقف النقود، والطعام يكون على أكثر من طريقة، فإن كان وققها لإقراضها، فإن بلان القرض يقوم مقام بقاء الطاء

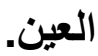

قال ابن عابدين: "إن الاراهم لا تتعين بالتعيين فهي وإن كانت لا ينتفع بها مع بقاء عينها لكن بدلها يقوم مقامها؛ لعدم تعيينها، فكأنها

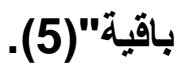

وإن كان وقف النقود يكون للمضاربة بها، وصرف ربحها على

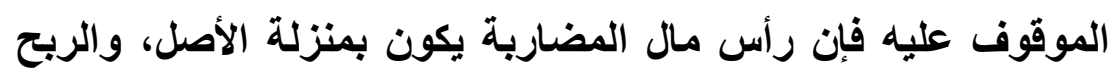

(1) قضايا فقهية معاصرة، د. محمد الجبالي ص282 الدمان. (2) المعاملات المالية أصالة ومعاصرة، د. د. دبيان الدبيان (16/ 190/ 192)، وما بعدها،

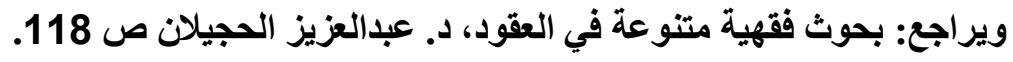

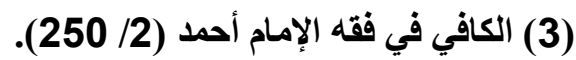
(4) المغني لابن قدامة (34/34)، الثرح الكبير على متن المقتع (194/ (191/). (5) حاثبة ابن عابدين (4/4/ 364). 
بمنزلة الثمرة، ومثله يقال في المضاربة بالطعام، فإن الصحيح جواز

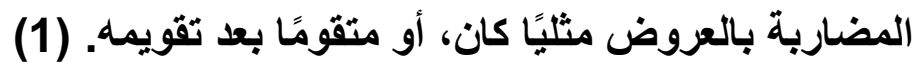

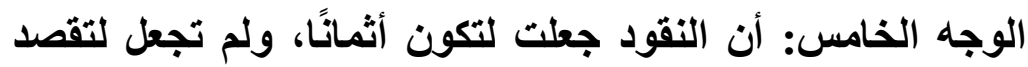

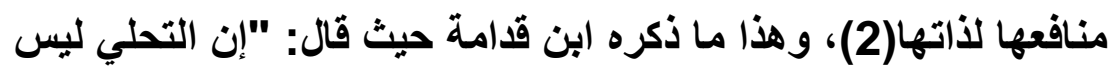

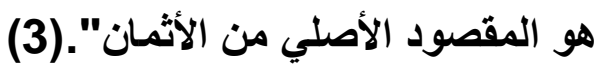

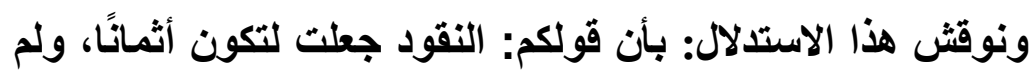

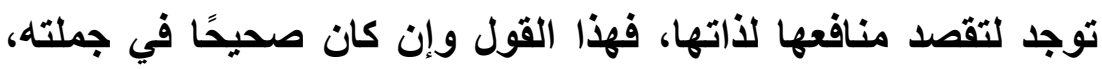

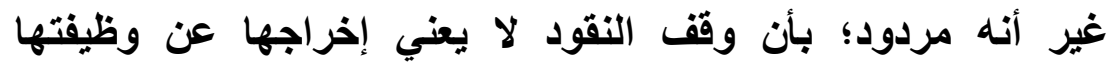

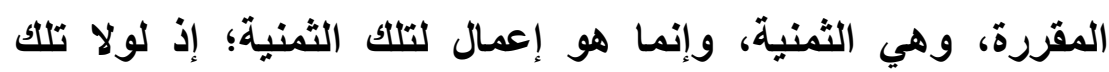

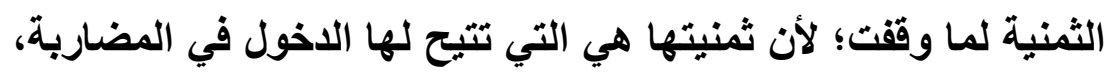

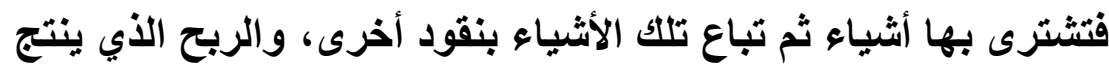

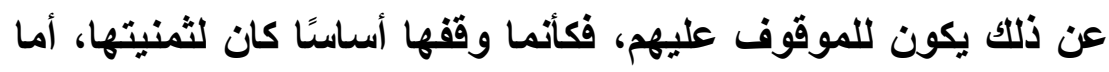

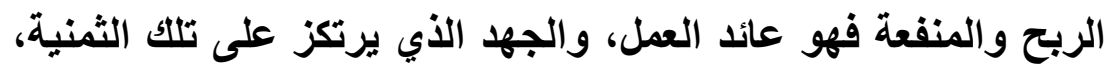

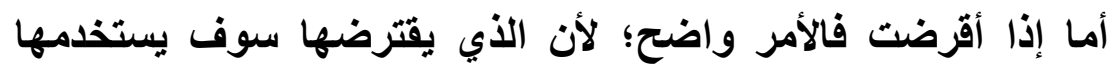

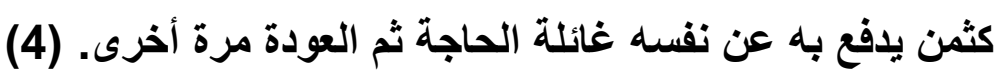

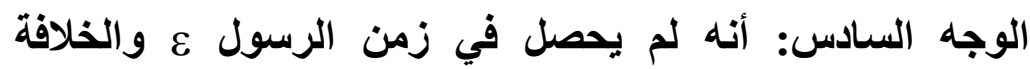

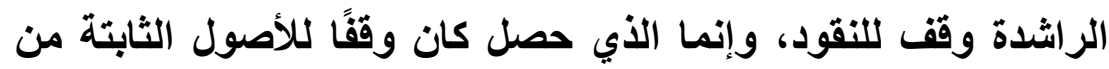
أراض وعقار ات. (5) ونوقش هذا الاستدلال: بأن القول بوقف النقود لم يحدث في عصر الترائ

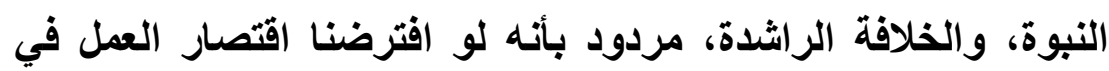

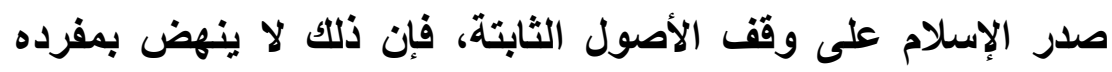

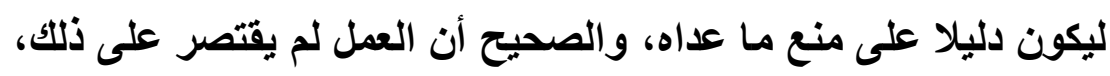

(1) المعاملات المالية أصالة ومعاصرة د.دبيان الابيان(16/ 190)، ومائة وما بعدها.

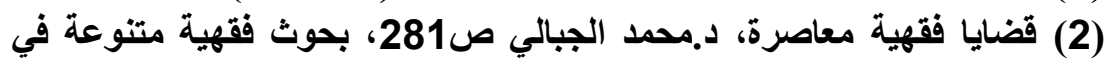

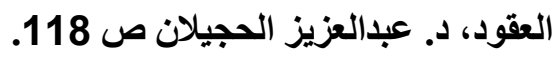

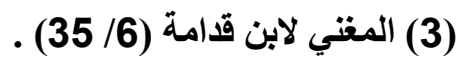
(4) قضايا فقهية معاصرة، د. محمد الجبالي ص284.

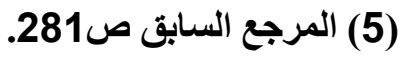


وإن كان هو الغالب، و إلا فهناك وقف خالد لأدُرُعه وعتاده، و هي أموال

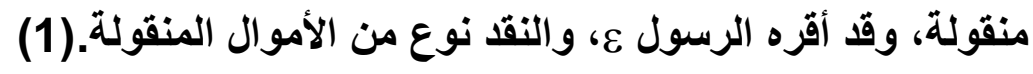
كما أن وقف النقود وإن لم يكن معروفا قديما إلا أن العرف السائد

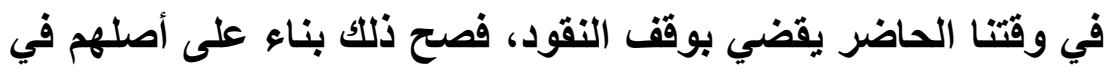
اعتبار العرف في المسألة.

الوجه السابع: إنّ الوقف النقدي يواجه مخاطر تغيّر القيمة

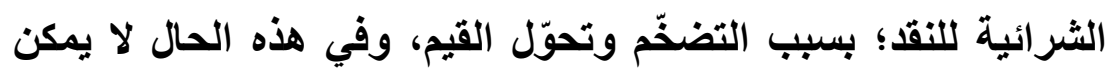
خوض هذا المجال؛ لأنه يعرّض الوقف لمخاطر يفترض حمايته منها.

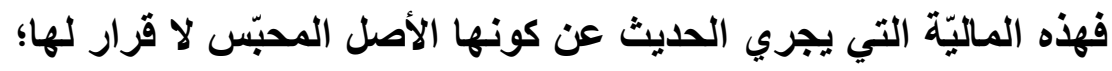

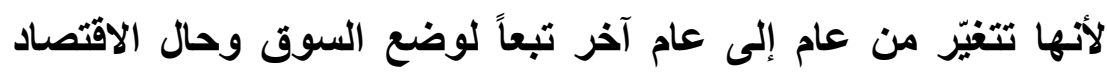

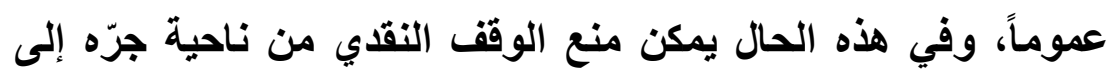

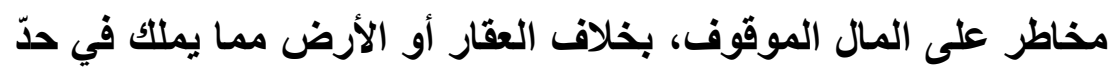

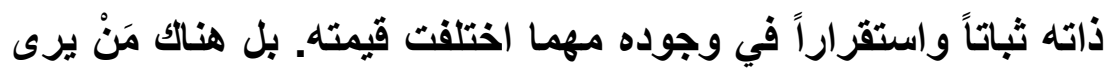

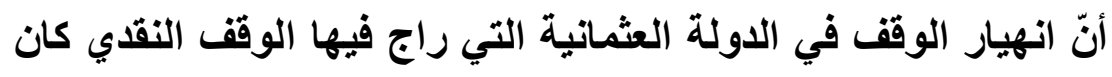

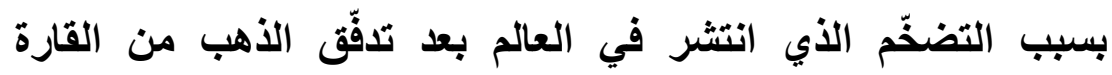

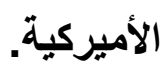

ليس هذا فحسب، بل يواجه الوقف النقاي مخاطر السرقة،

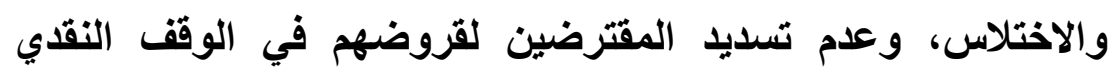

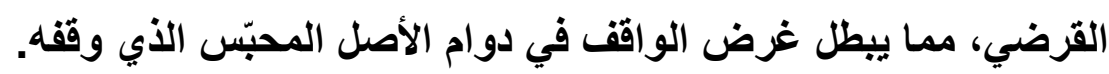

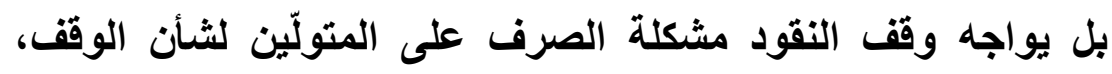
حيث لا بد أن يستهلكوا مقاراً من الأصل حينتخٍ. ونوقش هذا الاستدلال بأمرين:

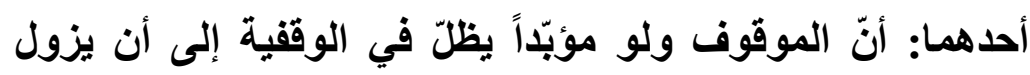

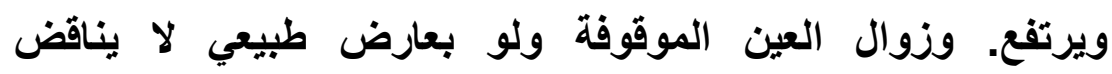

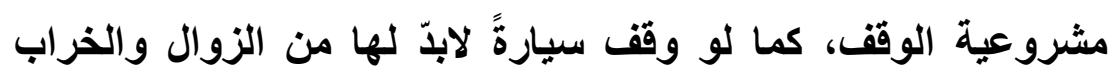


بمرور الزمن. وهذا معناه أنّ الوقف يتبع حال الموقوف من حيث

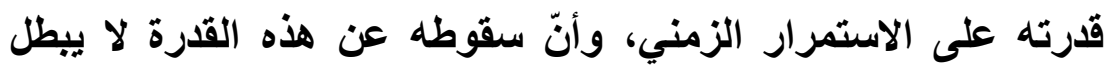

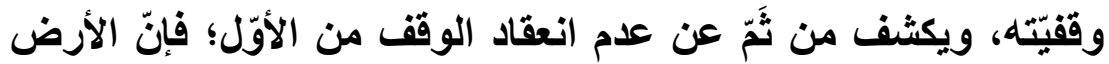

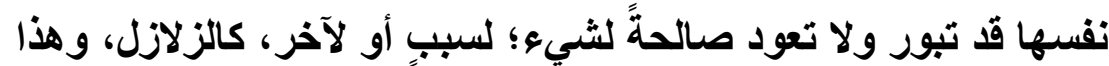

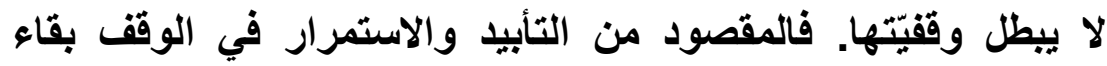
الموقوف موقوفاً إلى زواله واندثاره، لا التأبيا بمغنى بقائه إلى أن الن النائ يبعث الله الأرض ومَنْ عليها بالضرورة نَّة ثانياً: إنّ الزوال المفترض هنا بنا يمكن تفاديه بما يرتهن بإدادارة

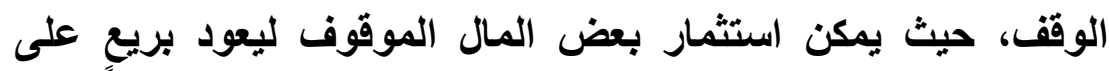

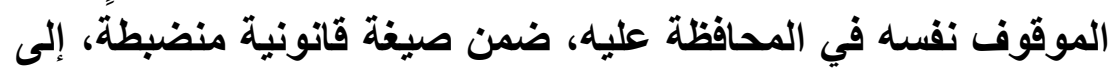
جانب التثدّد في الحصول على ضمانات من عقار التهات وصكوك في دائرة

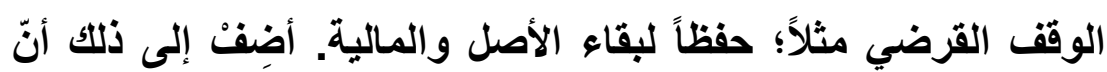
عملية تحريك الموقوف النقدي لا تقتصر على تحويله من نقد إلى آخر، التهل بل قد يكون بتحويله إلى أعيان يتّجر بها، ولاسيما في الوقف النقدي

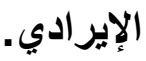

فهذه الإثكالية يرجع الثطر الأكبر منها إلى مسؤولية إدارة

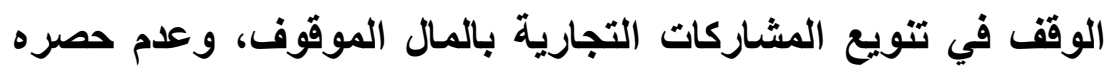

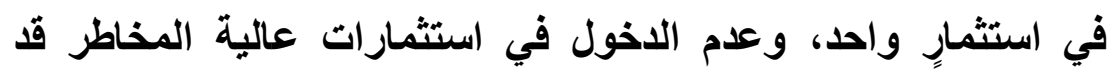
تضرّ بالأصل الموقوف، ويكون الإقدام عليها مخالفاً لوظيفة الناظر

والمتولّي في هذا المجال. (1)

الرأي الثاني: يصح وقف النقود مع الكراهة، وهو قولّ عند

المالكية نسب إلى ابن رشد (2).

(1) الوقف النقاي في الفقه الإسلامي قراءة استلالية، حيدر حب الله، (ص19، (20)

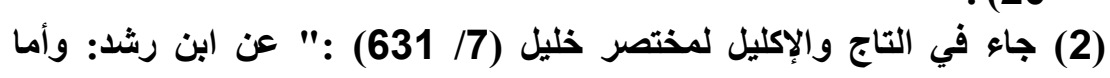
الاناتير والاراهم وما لا يعرف بعينه فتحبيسه مكروه.". 
واستدلوا على ذلك بلليلين، أحدهما على صحة وقف النقود،

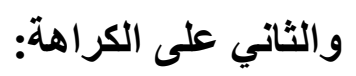

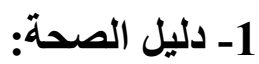

استدل المالكية على صحة وقف النقود بناء على أنهم لا يرون

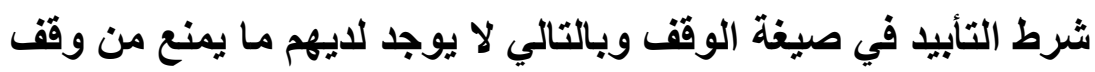

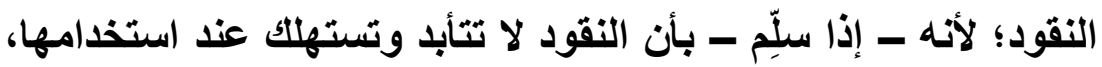

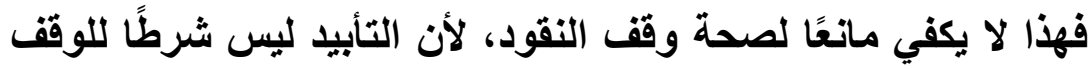

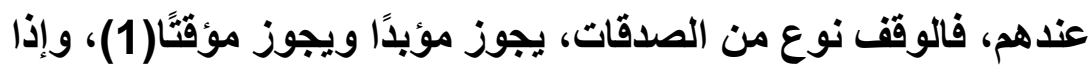

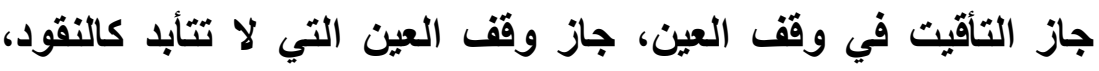
وسائر المنقولات.

وموقف المالكية هذا من جواز وقف النقود ينسجم مع موقفهم من

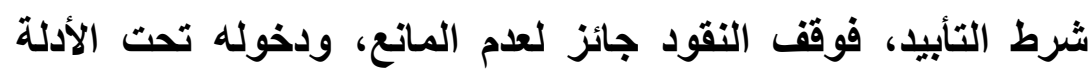
العامة على مشروعية الوقف.

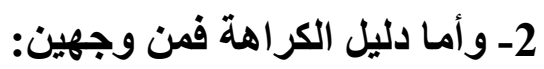
الأول: أن المالكية لعلهم قصدوا الخروج من الخلاف، من بين وجنا: القول بالمنع المطلق والجواز المطلق. ونوقش هذا الاستلال: بأن هذا دليل ضعيف؛ لأن الكراهة حكم شرعي يقوم على دليل شرعي، والخروج من الخلاف ليس من أدلة الثيتلة

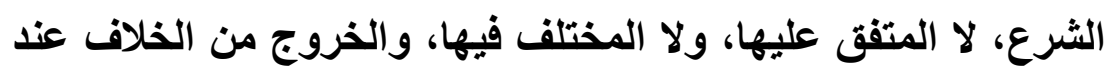
من يقول به في بعض المسائل، لا يؤدي إلى إحداث قول قائم برأسه، ولاه وإنما يكون الخروج من الخلاف في مسألة يكون الخلاف فيها فوئيا،

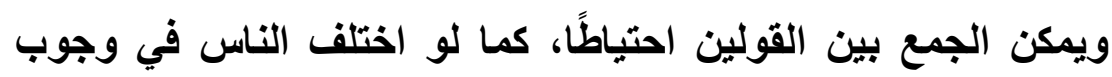

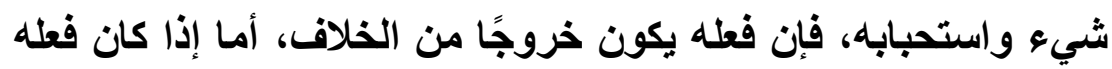

(1) ينظر : التاج والإكليل (7/ 631)، مواهب الجليل (6) (22)، (264)، شرح مختصر خليل

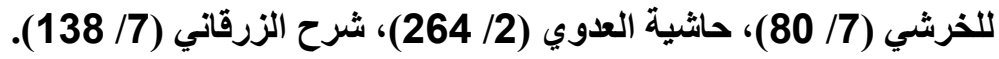
(2) وقف النقود (حكمه، تاريخه وأغراضه، أهميته المعاصرة، استثماره)، د. د. (264)،

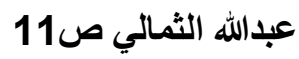


يدور بين الصحة والبطلان فلا تكون الكراهة خروجًا من القول

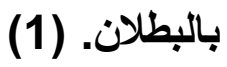

الثاني: أن الكراهة اقتصرت على أن وقف النقود يمثل تحجيراً

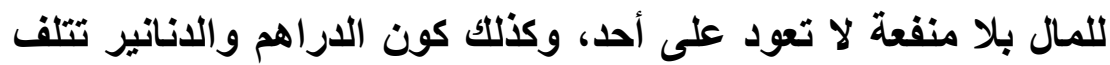
Oالاستعمال، وقد تمت مناقثتئه ذلك في أدلة المانعين. (2) الرأي الثالث: صحة وقف النقود (الدنانير والاراهم) إذا جرى لثاني بوقفها التعامل في عرف الناس، وهو ما ذهب إليه محمد بن الحسن

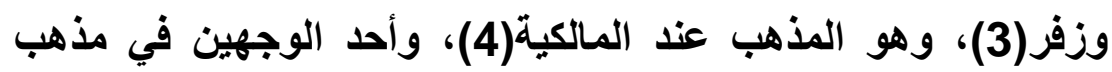

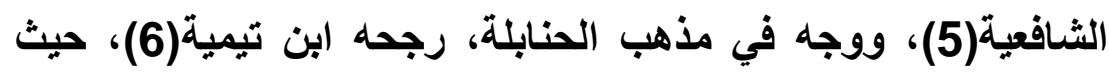
يرون أن المنقول إذا جرى التعامل بوقفه صح وقفه.

$$
\text { (1) المعاملات المالية أصالة ومعاصرة (16) 191، 192، 192) . }
$$

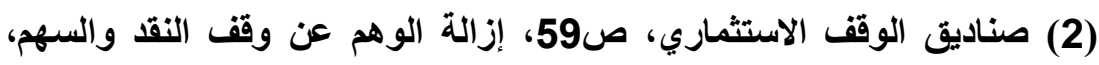

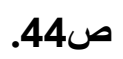

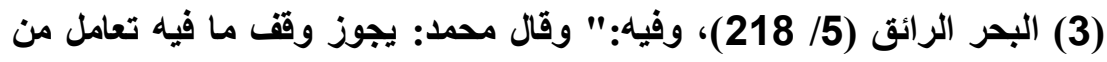

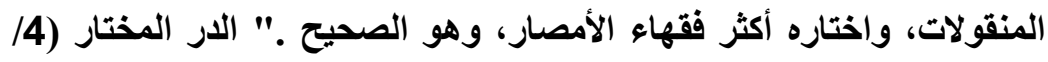

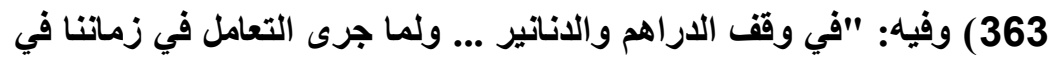

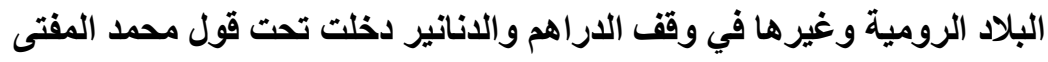

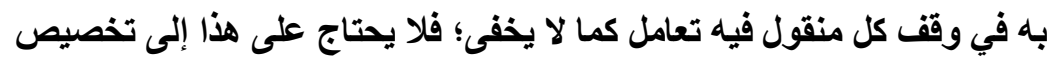

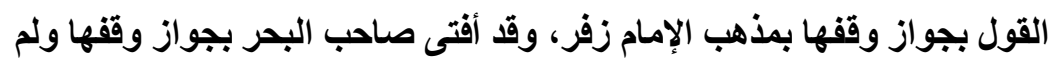
يحك خلافا." (4) شرح مختصر خليل للخرشي (7/780)، وفيه:" أن التردد في غير الانتير

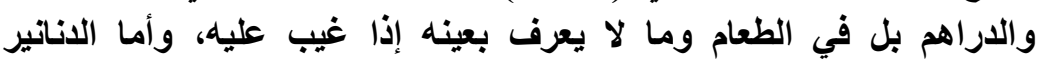
والاراهم فيجوز وقفهما للسلف قطعا."، التوضيح في شرح مختصر ابن

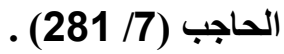

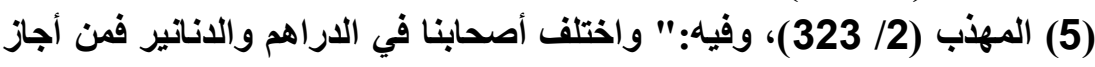

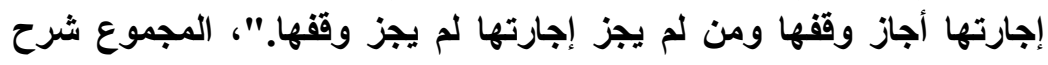

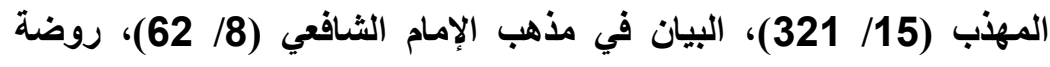

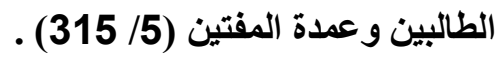
(6) الإنصاف للمرداوي (7/ 11)، وفيه: "يصح وقف الاراهم. فينتفع بها في القرض ونحوه. اختاره شيخنا. يغني به الثبخ تقي الدين - رحمه الله -."، في 
فيجوز الوقف فيما يتعارف الناس وقفه كالمنشار والفأس والمصحف لقراعة القرآن والقدور والمراجيل، وما لم يتعارف الناس وقفه لا يجوز وقفه، كالثياب وغيرها من الأمتعة(1)؛ لوجود التعامل

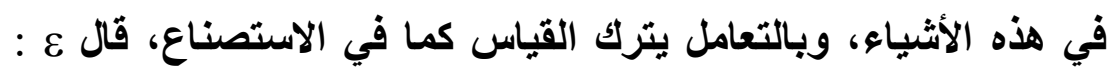

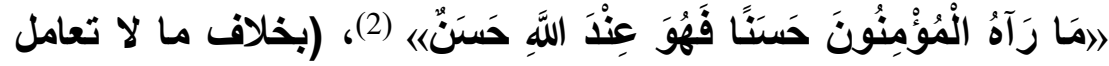
فيه) كالثياب والأمتعة؛ لأن من شرط الوقف الثون التأبيد كما بينا، تركناه في

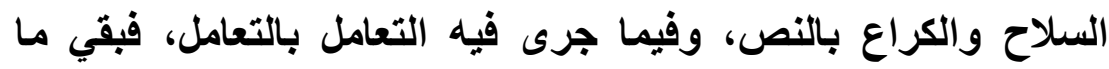

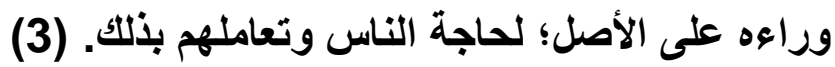

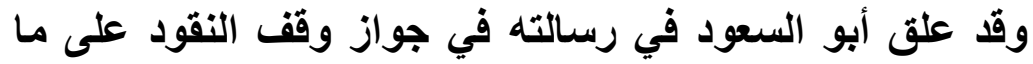

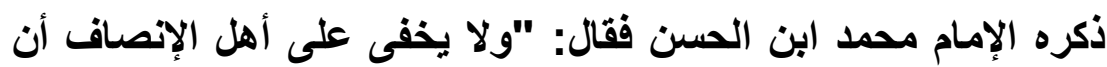

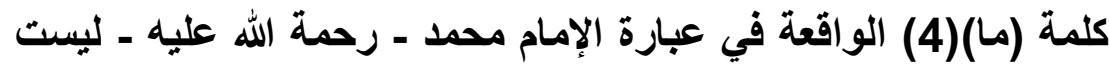
عبارة عن بعض المنقولات المعهودة ولا مخصصة بما ذكر من الأمثلة،

مجموع الفتاوى (31/ 234، 235) وفيه:" يجوز وقف الدنانير؛ لأنه لا ينتفع

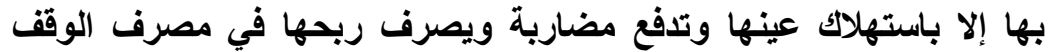

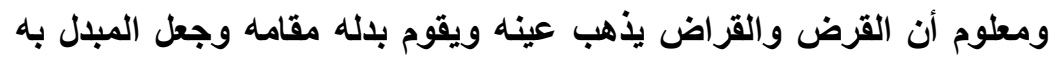

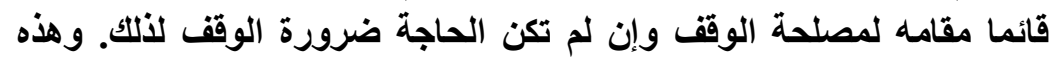

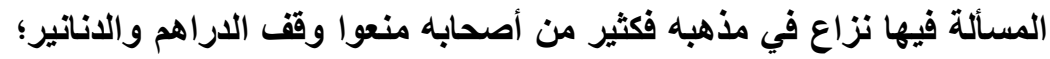

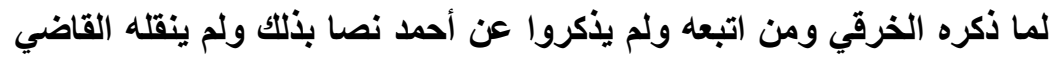

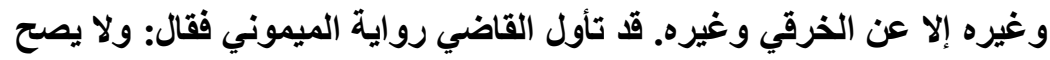

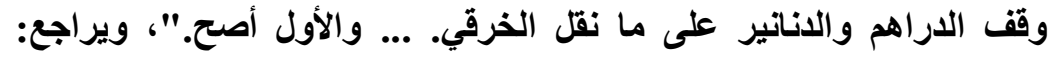

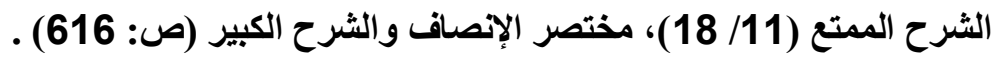

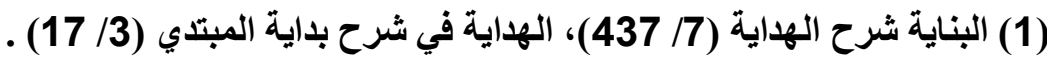

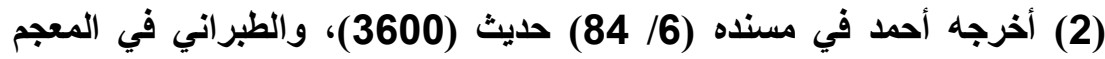

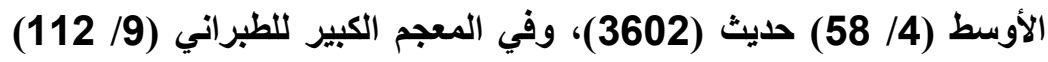

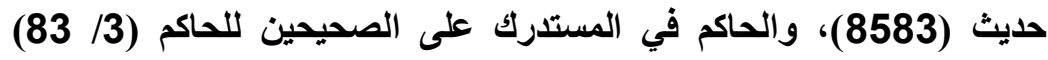

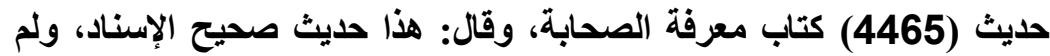

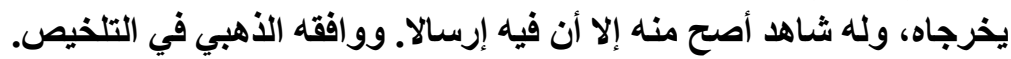

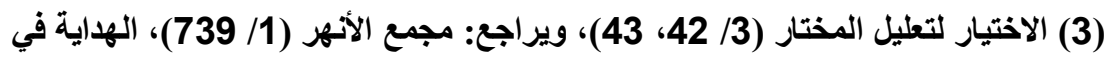

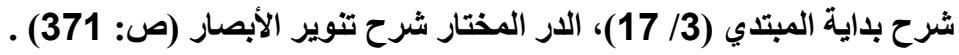
(4) يقصد (ما) في قوله: "ما يتعارف الناس وقفه". 
بل هي مجراة على عمومها حسب عموم ما وقع في حيز الصلة من

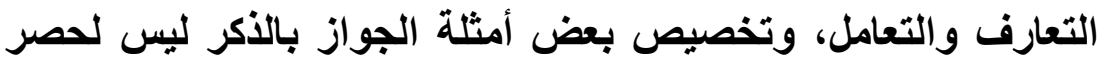

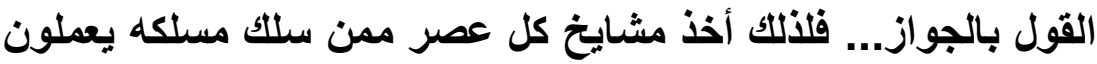
بموجب ذلك العموم ويجييون في كل مادة بالإيجاب والنفي حسبما عاينوا في أعصارهم من التعارف وعدمه من غير تفرقات فئة بين منقول

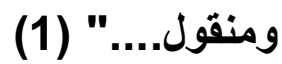
الرأي الرابع: يصح وقف الدراهم والدنانير إن صيخ منها طي، ولا يجوز وقفها إن أريد بها الإقراض أو الاتجار، وهو قولّ عند

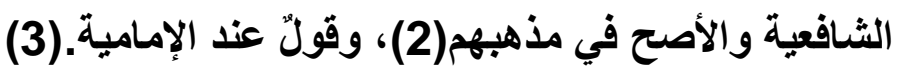
واستدلوا على ذلك: بأن الذهب والفضّة إذا كان حليّاً فإنه يجوز وقفه؛ لأنه عين يمكن الاتتفاع بها مع بقائها، كالعقار تماماً؛ نظراً

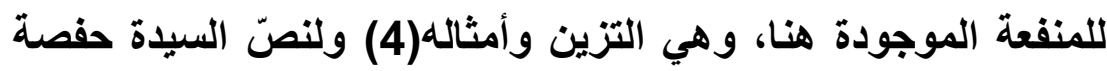

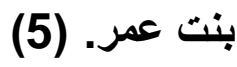

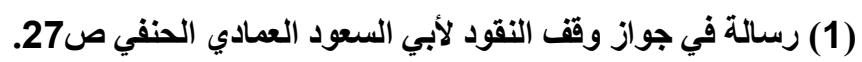

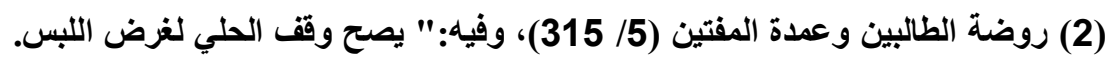

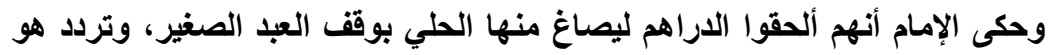

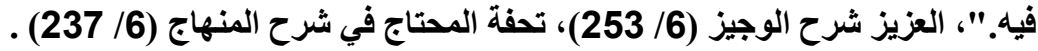

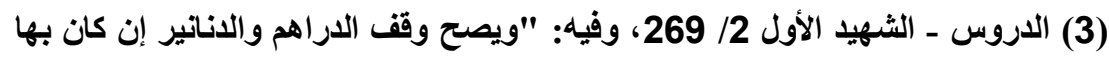

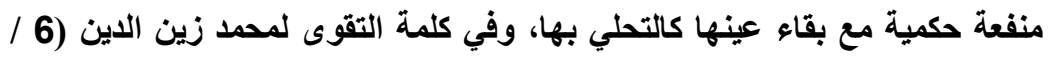

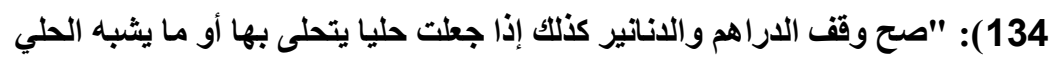

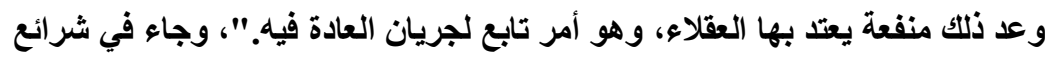

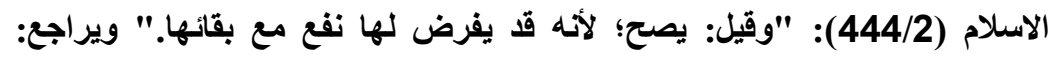

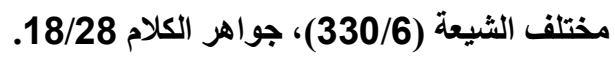

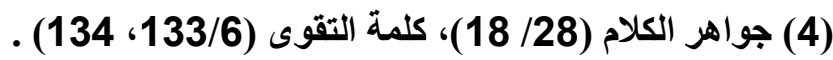

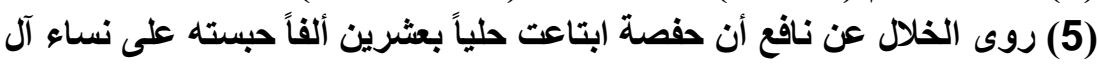

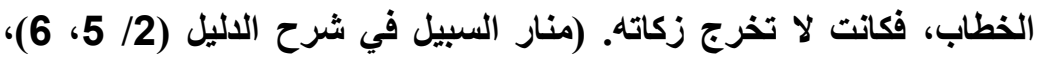

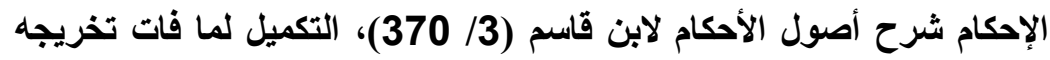

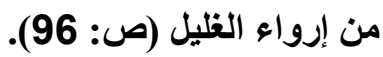


كما أن اللراهم والدنانير مما يتلف بالاستعمال، فلا يصح وقفها؛ لأن الوقف يقتضي فيه الدوام، وإذا قصد بوقفها أن تصاغ حلياً جاز

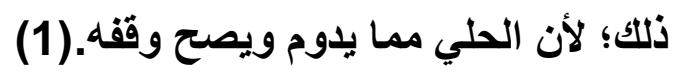
ونوقش هذا الاستدلال: بأن القول بعدم جواز وقف الدراهم

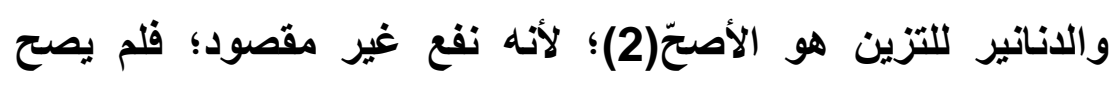
وقفه(3). الرأي الخامس: جواز وقف الدنانير والدراهم لغرض إقراضها، أو للإتجار بها وصرف أرباحها في الموقوف عليهم، وهو قول محمد بن عبد الله الأنصاري(4) وزفر من الحنيفة(5)،وهو المعتمد عند المالكية(1)، وقول عند الثافعية(2) ،وقول عند الحنابلة

قال الألباني: "وإسناده ضعيف، لضعف سعيد بن مسلمة، قال ابن معين: ليس

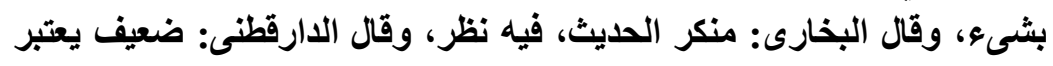

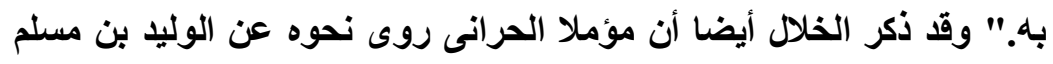

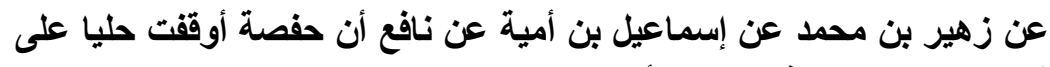

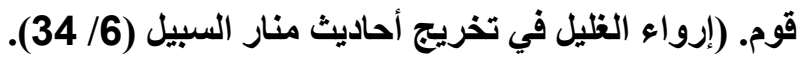

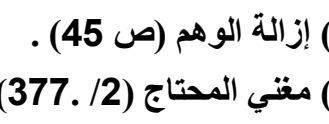

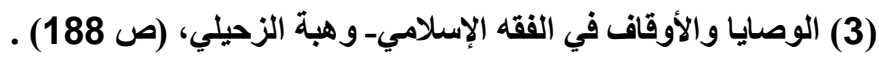

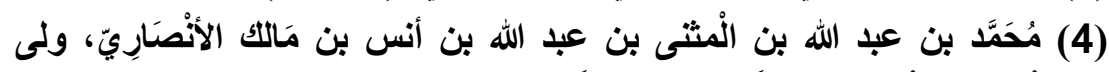

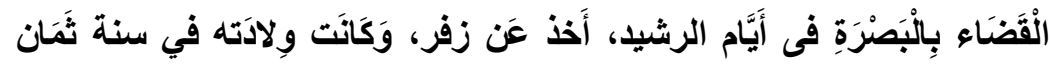

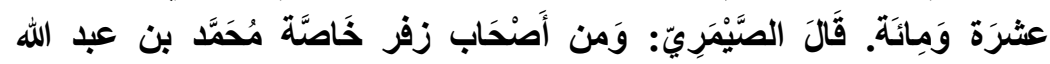

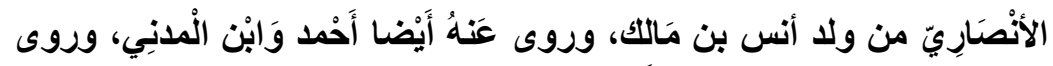

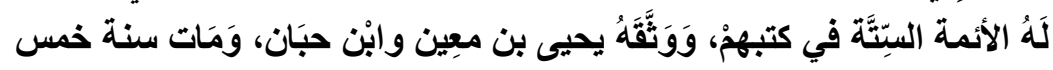

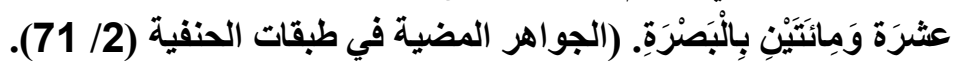

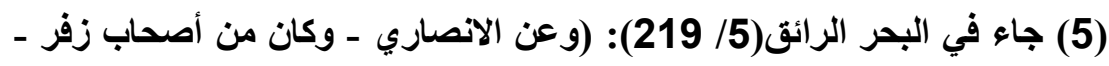
في سن وقق الاراهم أو الاناتير أو الطعام أو ما يكال أو يوزن أيجن أيجوز؟ قال: 


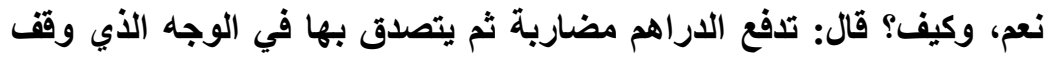

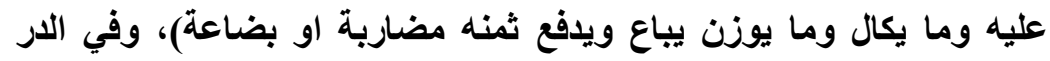

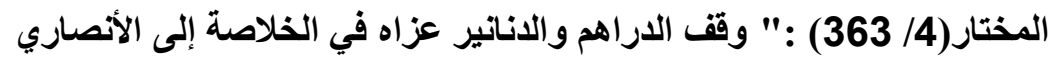

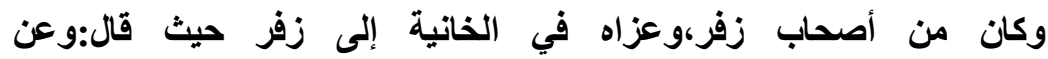

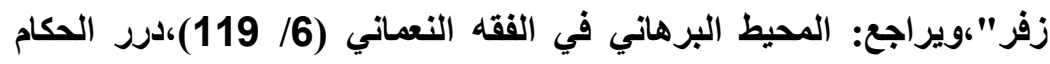

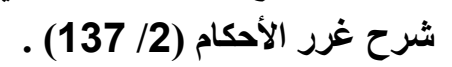

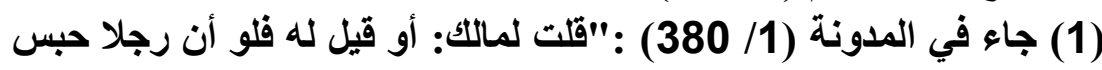

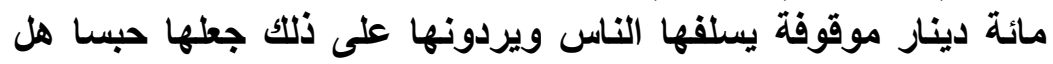

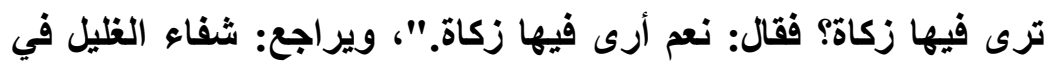

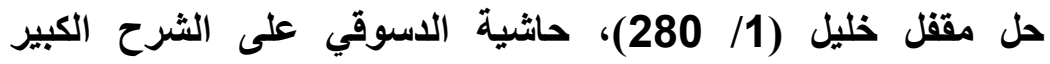
ج) (120/4)

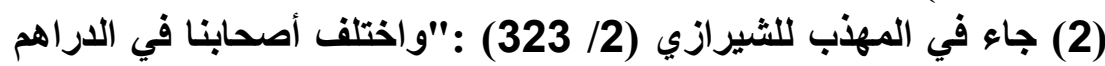

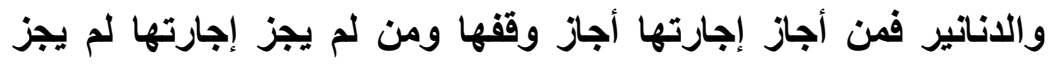

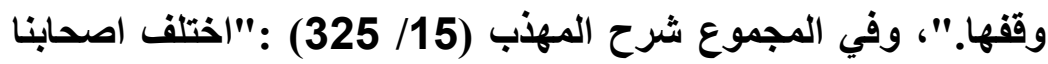

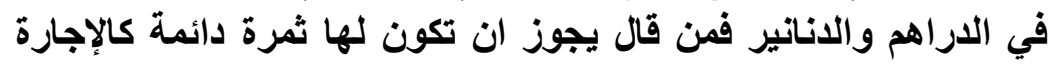

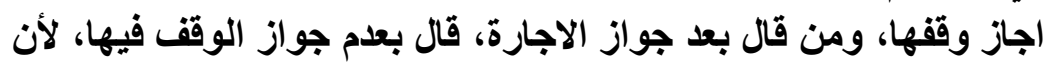

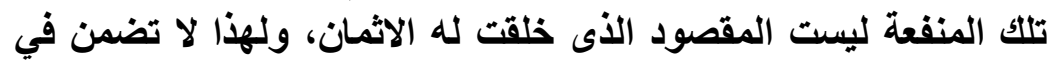

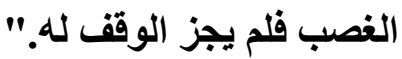




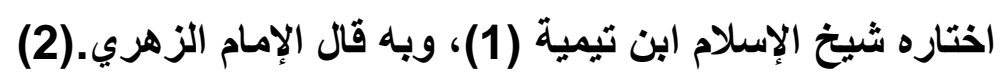

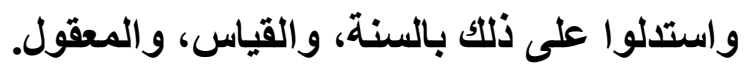

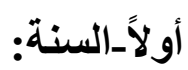

يستدل على جواز وقف النقود بالأحاديث التالية:

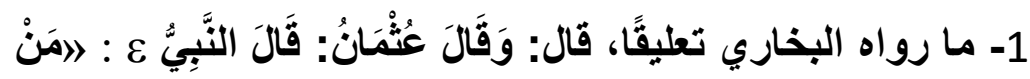

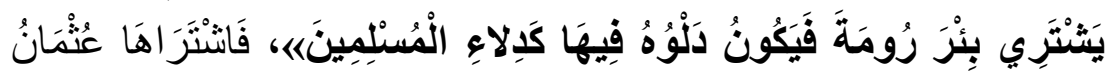

(3). $\tau$

(1) جاء في الوقوف والترجل من مسائل الإمام أحمد (ص: 23) :"عن إسماعيل بن سعيد

قال: سألت أحمد عن الوقوف فقال: هي جائزة في كل شيء")

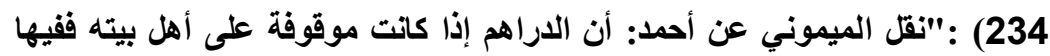

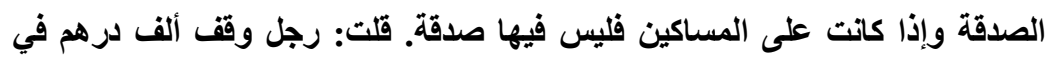

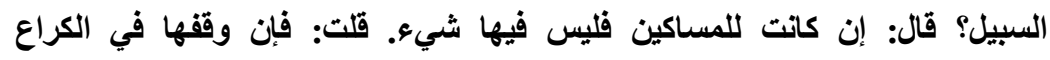

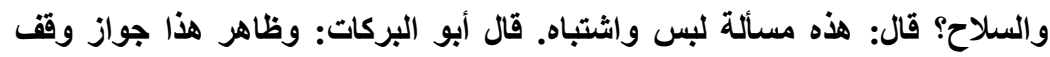

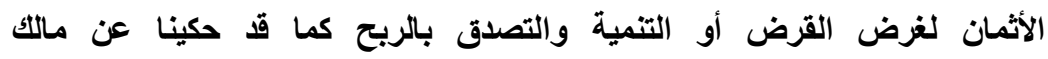

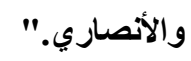

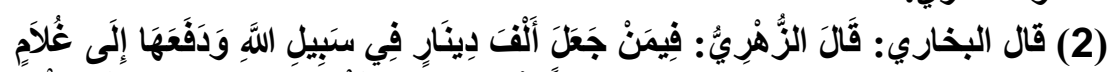

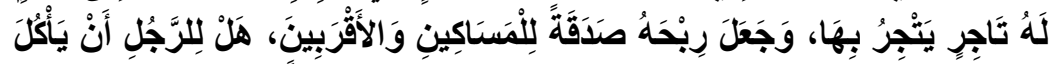

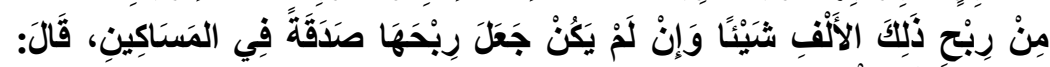

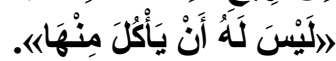
(أخرجه البخاري - تعليقا ـ في صحيحه (4/ 12) كتاب الوصايا، باب وقف

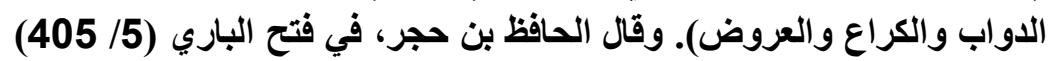

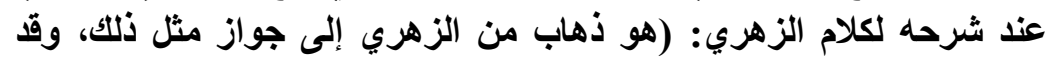

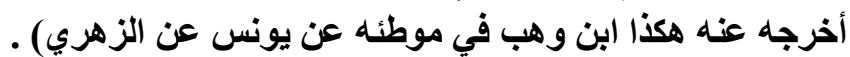

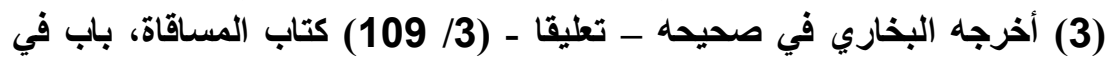
الشرب ومن رأى صدقة الماء وهبته ووصيته جائزة مقسوما كان أو غير كئه مقسوم. وأخرجه موصولا: ابن خزيمة في صحيحه (4/ 121) حديث (2492) كتاب الزكاة، باب إباحة شرب المحبس من ماء الآبار التي حبسها، قال الأل الألباني: إسناده

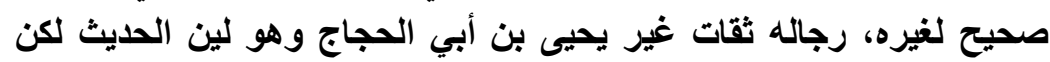

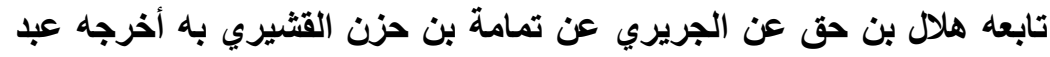

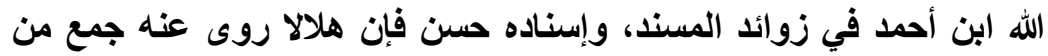

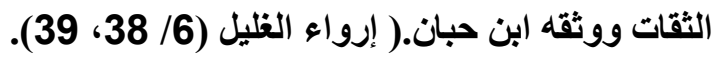


وجه الدلالة: دل الديث على أنّ الماء يملك ويوهب ويتصدق به

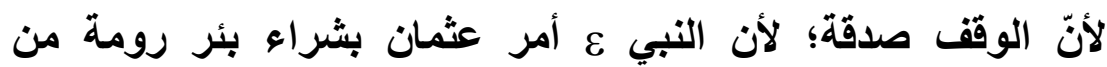

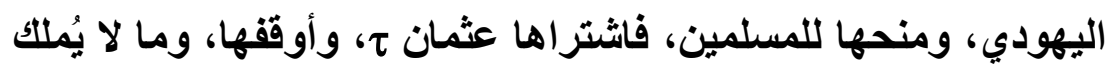

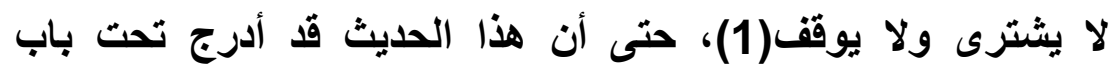
(صدقة الماء وهبته ووصيته جائزة) (2). فإذا صح وقف الماء وهو منقول، ولا يتأبد، وتستهلك منفعته باستهلاكه، صح وقف النقود، إذ لا فرق بينهما. ويمكن مناقشة هذا الاستدلال : بأن الموقوف في الحديث هو البئر وأنه أعم من وقف الماء، والبئر غير منقول(3)، قال القسطلاني في شرحه لهذا الحديث: "فاشتراها عثمان ح ووقفها على الفقير والغتي وابن السبيل." (4) (4)

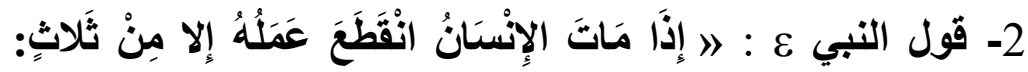

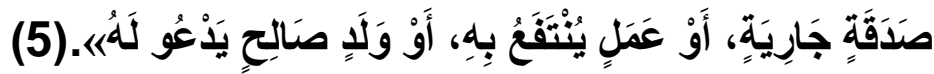
وجه الدلالة من الحديث: دل هذا الحديث على جواز الوقف

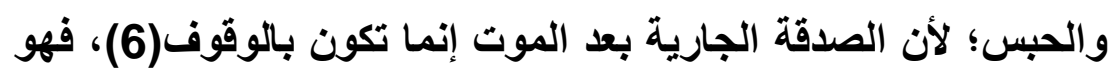

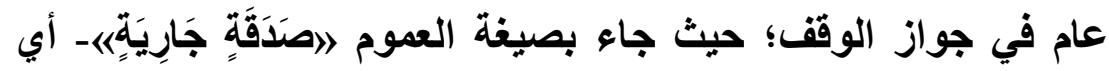
يجري نفعها ويدوم أجرها - (7) ولم تحدد نوعية تلكك الصدقة أيَّا كانت أثمانًا أو عقارات أو منقولات، فقد جاء اللفظ عامَّا، ومن ثم فلا يوجد

(1) منار القاري شرح مختصر صحيح البخاري (30/ 339)، ويراجع: فتح الباري . (30/5)

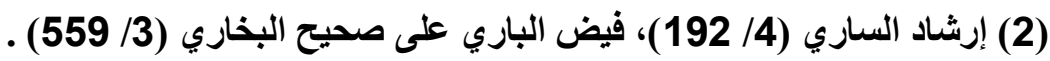

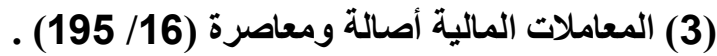

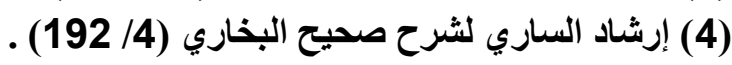
(5) سبق تخريجه في المقدمة.

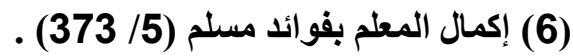
(7) مطالع الأنوار على صحاح الآثار (12/ 111) . 


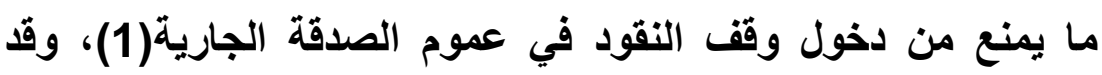

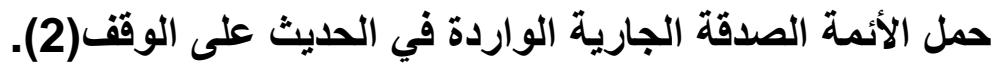

$$
\text { ثنانياً القياس: }
$$

قياس النقود على ما ورد به النص من المنقولات الأخرى كالكراع والسلاح وغيرها- بجامع أن كلا منهما منقول، يوجد فيهما غرض الوقف، وهو انتفاع الموقوف عليهم به في الدنيا، وحصول

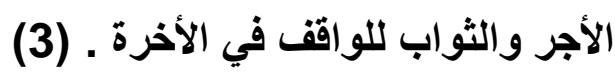

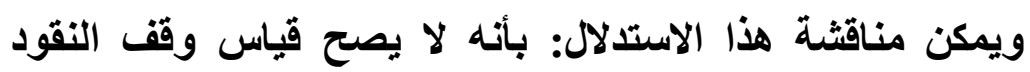

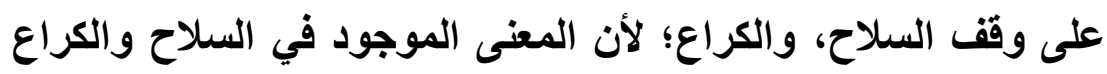
لا يوجد في النقود. جاء في فتح القدير: "حكم الوقف الثرعي التأبيد، ولا يتأبد غير

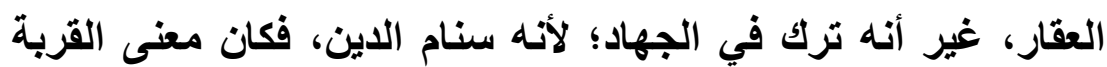

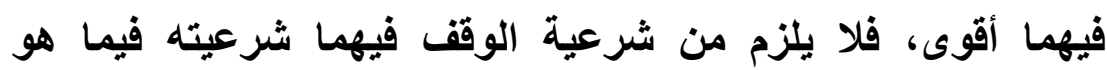

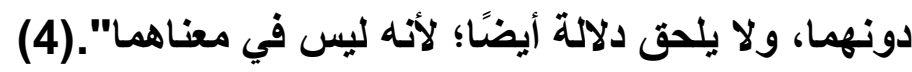

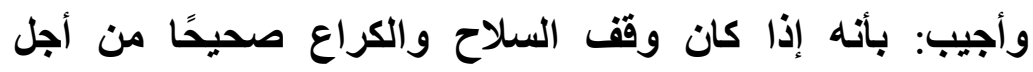

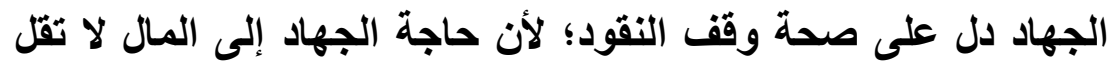

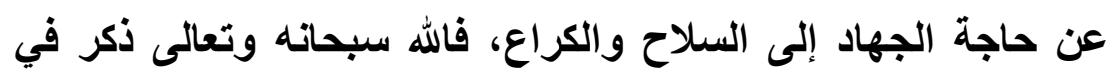

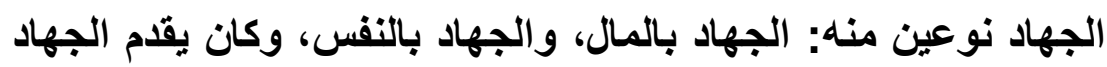

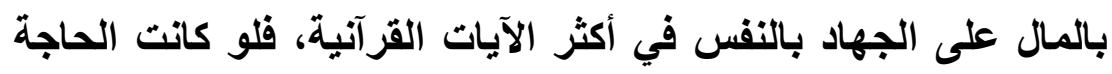

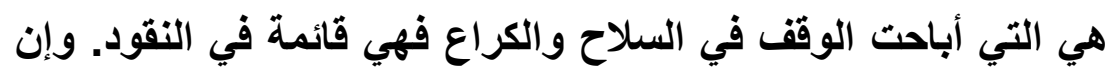

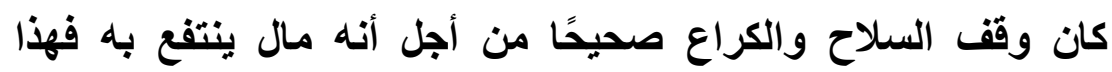

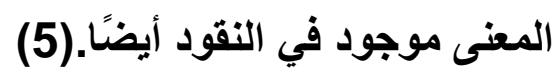

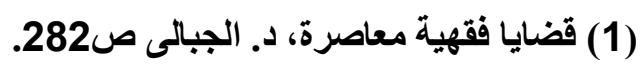

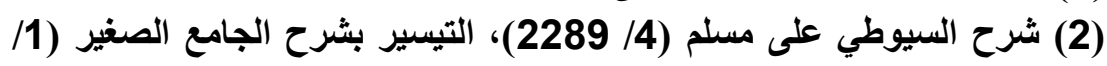

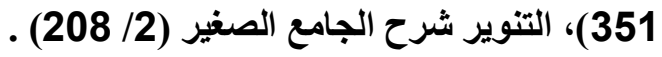

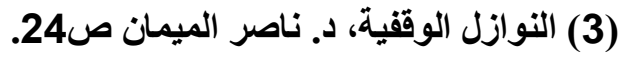

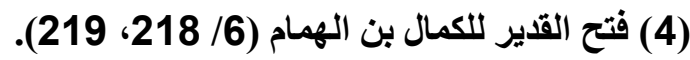

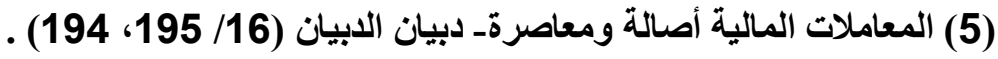


ثالثاً_المعقول: ويستدل به من سبعة وجوه:

الوجه الأول: دخول النقود في عموم الأدلة الدالة على جولئه جواز

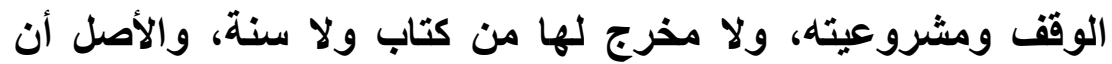
الاليل العام يبقى على عمومه، والمطلق على إطلاقه، حتى يرد دليل

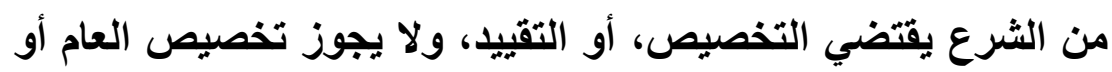

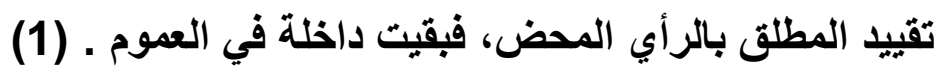

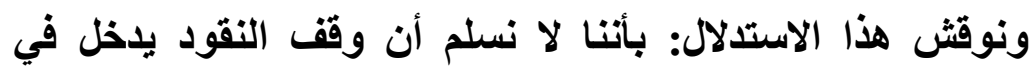

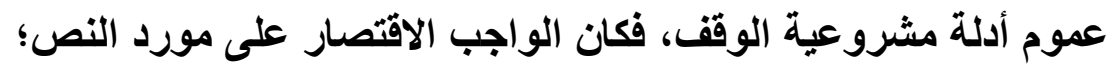
لأن الوقف تحبيس الأصل وتسبيل الثمرة، والنقود لا يحبس أصلها؛

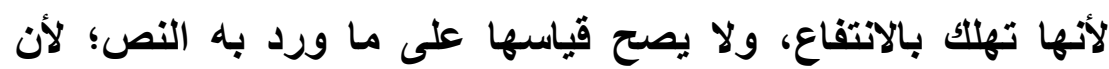
المعنى الموجود لما ورد بـه النص لا يوجد في وقف النقود.

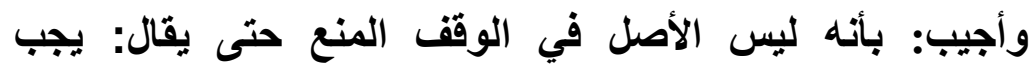

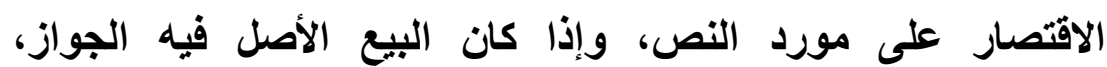

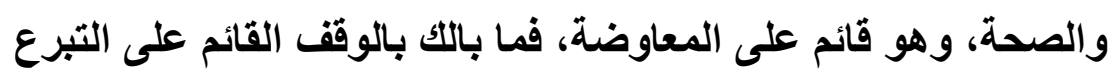

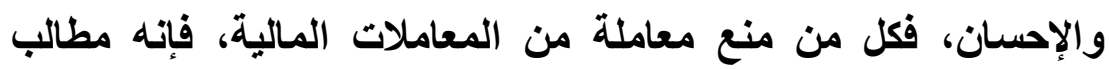

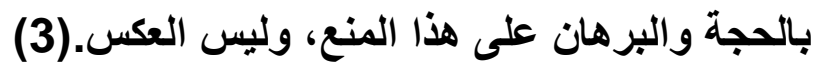

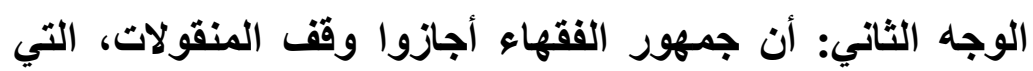
يمكن الإفادة منها مع بقاء عينها، وهذا ينطبق على الته التقود أيضًا؛ لأنها

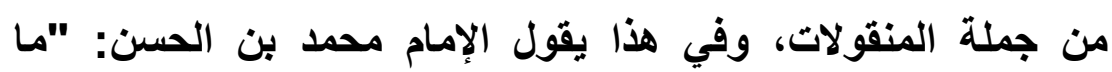

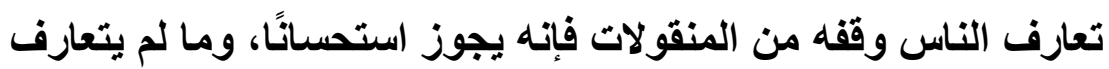
الناس وقفه لا يجوز، وقد كان وقف النقود متعارفًا في الايار

(4)."الرومية وناسة

(16) النوازل الوقفية للميمان ص262، المعاملات المالية أصالة ومعاصرة (16)

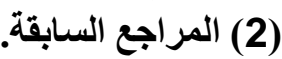

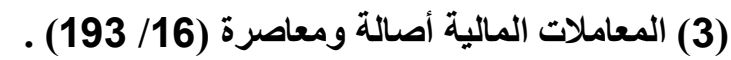
(4) رسالة في جواز وقف النقود، ص 26، 27، 27، النهر الفائق شرح كنز الدقائق 
الوجه الثالث: أن القصد الذي من أجله شرع الوقف متحقق أيضًا

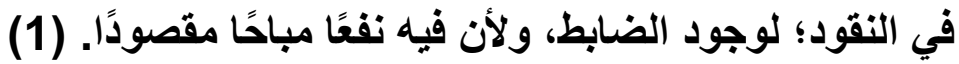

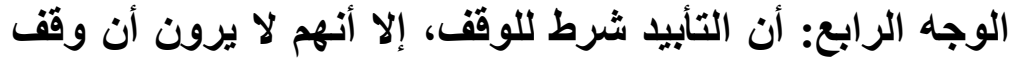

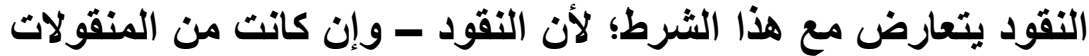

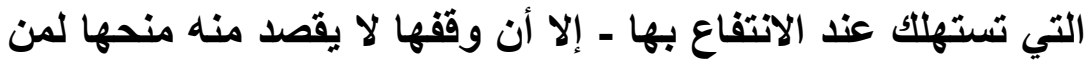

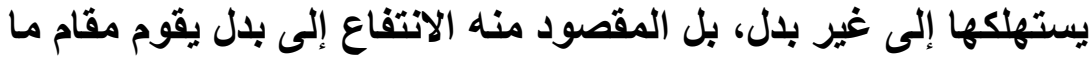

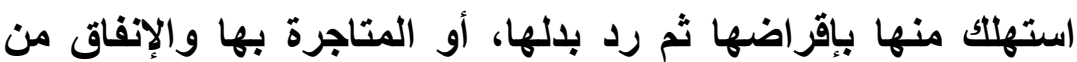

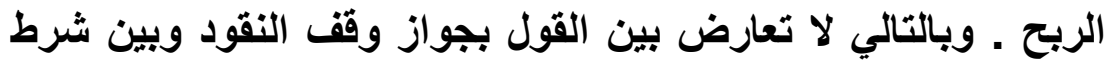

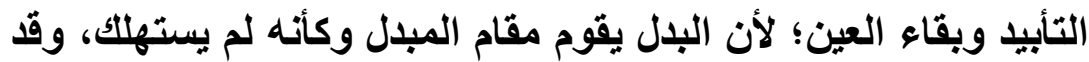

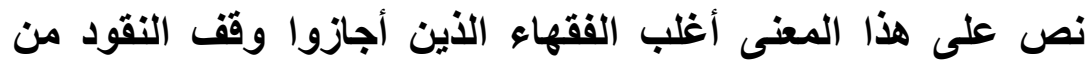

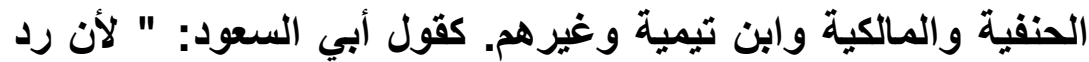

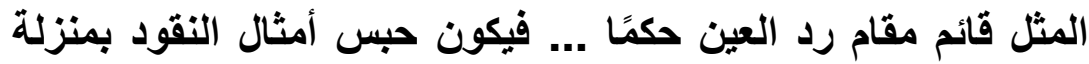
حبس أعيانها، وبقاء أمثالها في أثناء الاستعمال في حكم بقاء أعناء أعيانها،

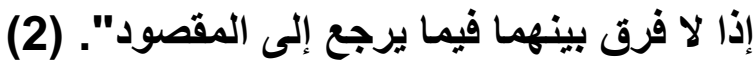
وذكر ابن عابدين أن النقود من المنقول، وأنها لا تتعين بالتعيين،

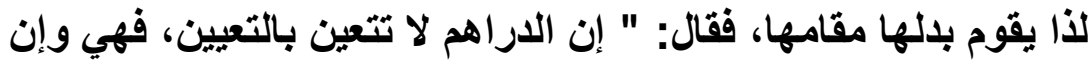
كاتت لا ينتفع بها مع بقاء عينها، ولكن بدلها قائم مقامها، لعدم تعيينها

كما أشار لهذا المعنى المالكية ـ بالرغم من عدم اشتراطهم التأبيد

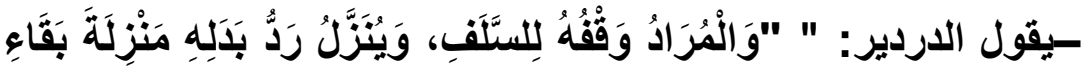

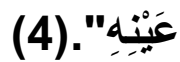

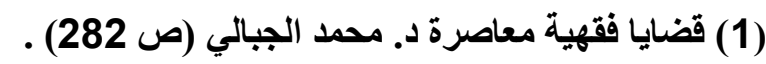

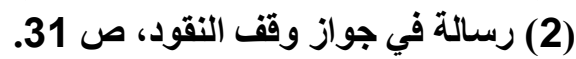

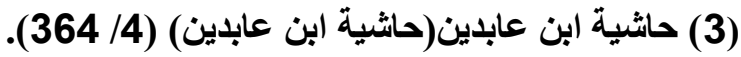
(4) الثرح الكبير للثيخ الدردير (14/ 77/ 7)، حاثية الصاوي على الثرح الصغير (100/4)،

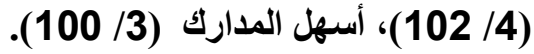


ويقول ابن تيمية " ومعلوم أن القرض والقراض (المضاربة)

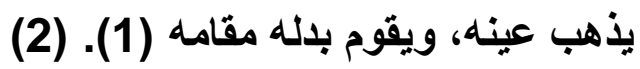

الوجه الخامس: أن الوقف من عقود التهبه (1) التهرع، ويراد للإرفاق

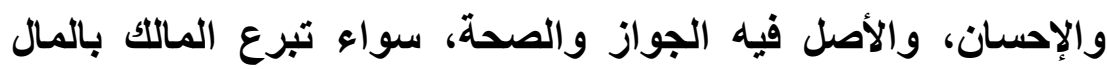

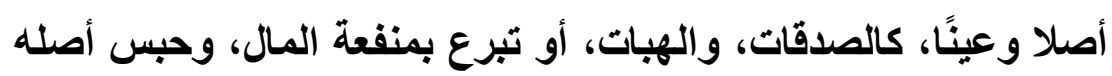

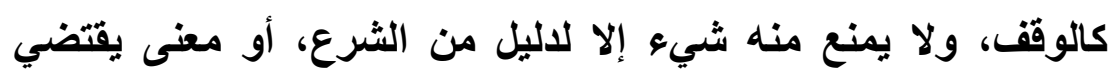

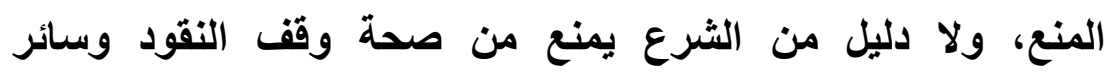

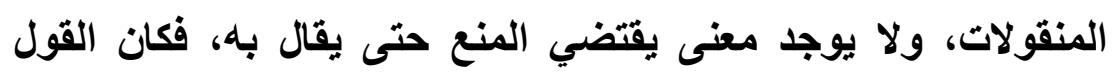

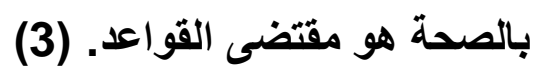
الوجه السادس: أن الوقف من أمور التبرّ التعات التي يتسامح فيها؛

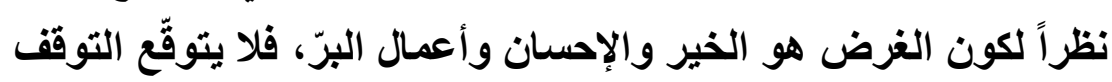

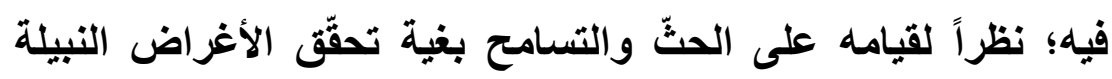

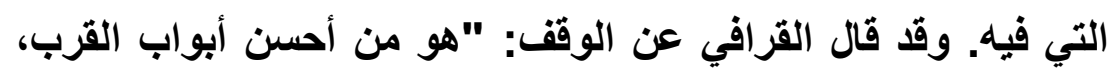

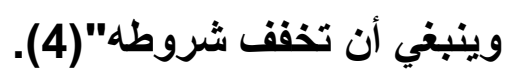

ونوقش هذا الاستدلال: بأنه دليل غير واضح؛ لاحتمال وجود

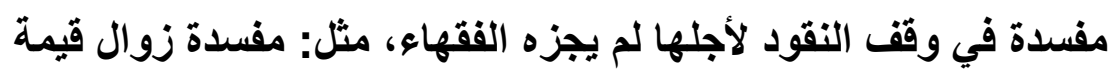

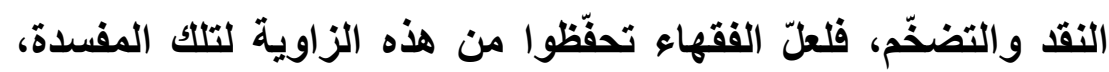

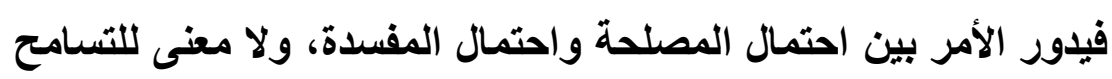

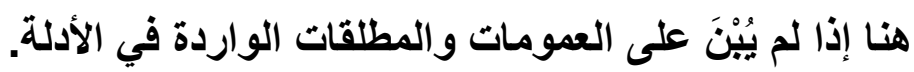

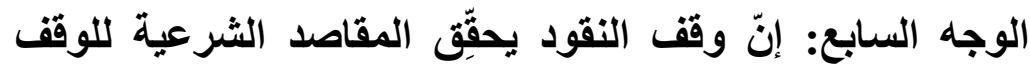

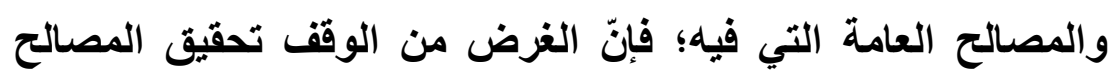

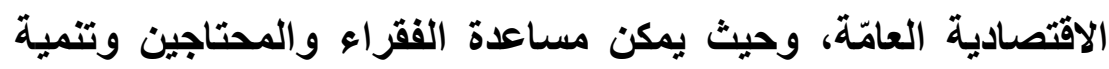
الاقتصاد وإقامة المشاريع الخيرية الكبرى من المساجد والمستثفيات ولئية

(1) مجموع الفتاوى (31/ 234).

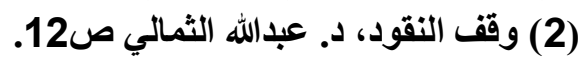

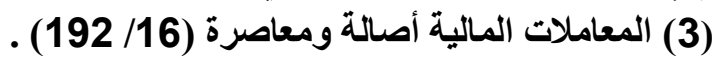
(4) الأخيرة للقرافي (6/ 322) باختصار. 
والمدارس والمعاهد الدينية والجامعات والمراكز الخدمية وطباعة

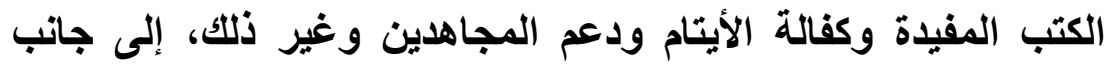

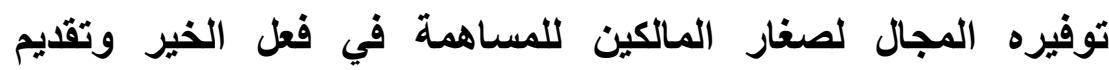

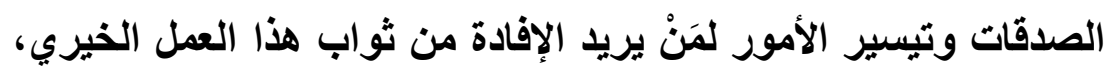

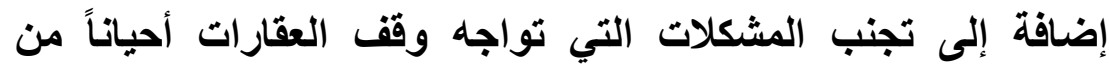

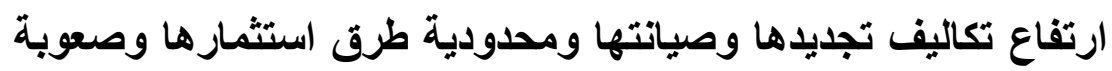

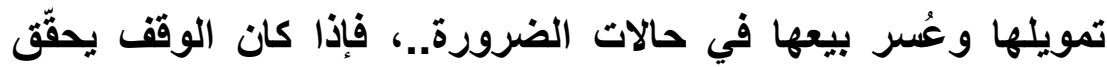

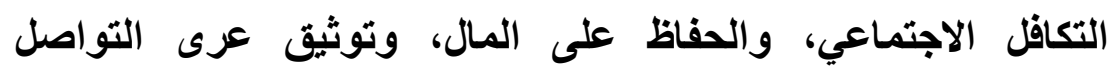

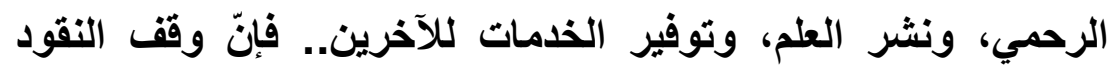

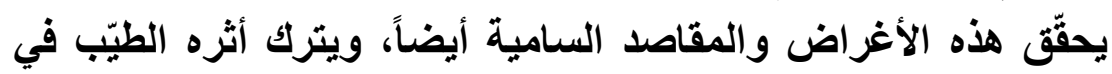

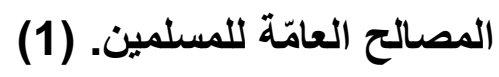

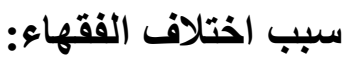

1- إن النقود من الأموال المنقولة، والمال المنقول قد جرى في الفي

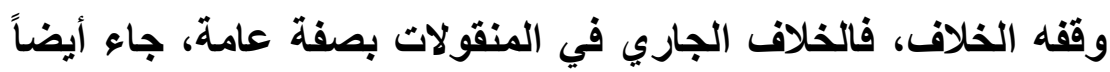

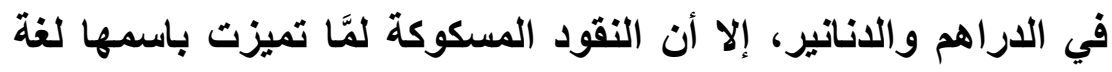
وعرفا وشرعا واستعمالاً جرى الخلاف في وقفها بصورة مستقلة.

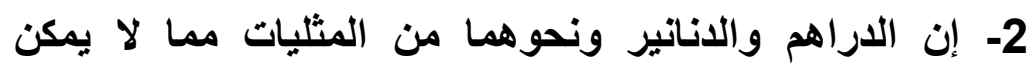

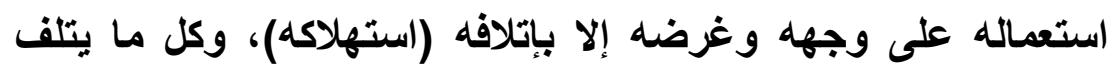
بالاستعمال جرى الخلاف في حكم وقفه باعتبار أن الوقف هو عو عبارة

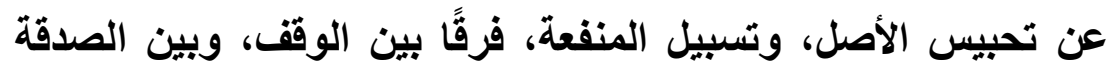
المطلقة.

والنقود، والطعام لا يمكن الوصول إلى منفعتها إلا باستهلاك

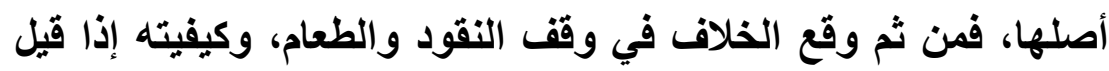
بالصحة.

3- إن من شروط الوقف: التأبيد، والدراهم والدنانير ونحوها مما

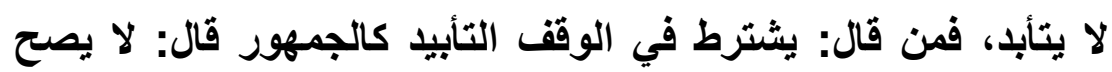

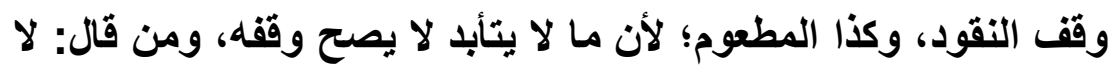


يشترط في الوقف التأبيد لم يمنع من وقف النقود والطعام، كالمالكية.

4- أن من خصائص الوقف: الانتفاع بالموقوف مع بقاء عينه،

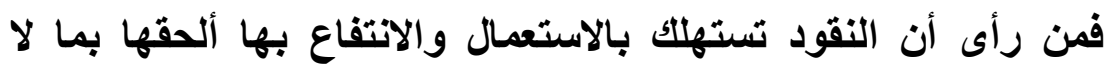

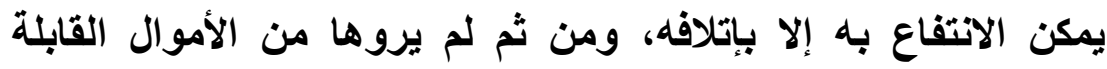

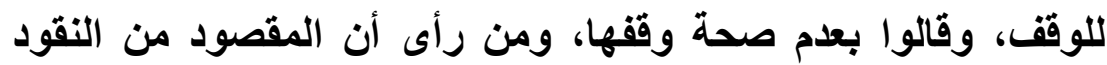

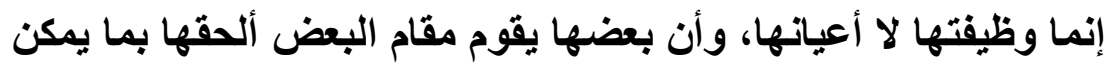

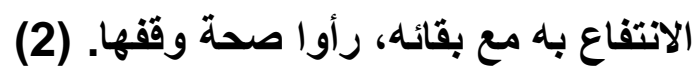

الترجيح: به:

بعد ذكر أراء الفقهاء وما ساقوه من أدلة ومناقثة فإن الذي يبدو

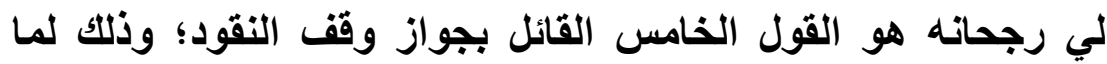
يلي: 1- قوة أدلتهم وسلامتها، مع ضعف أدلة المذاهب الأخرى.

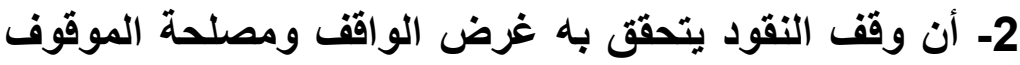
عليه ومقصود الثارع، أما غرض الواقف فهو مقصد بهد القربة، وأما

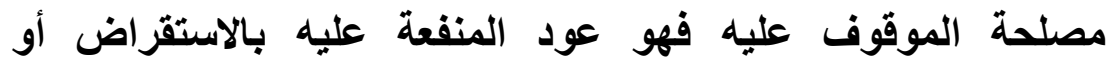

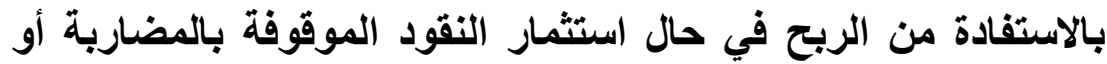

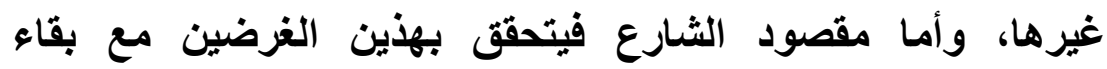
(3) (الأصل. (3)

3- أن المصلحة تقتضي الانتقال عن الأصل المعروف، في أن الوقف إنما يكون عقارًا أو منقولا لا يتضمن الانتفاع به استهلاك عينه

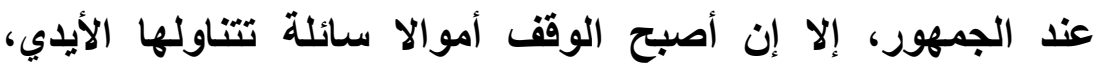

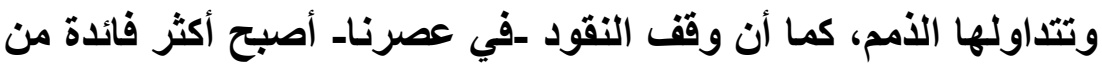

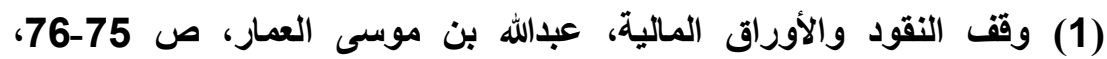

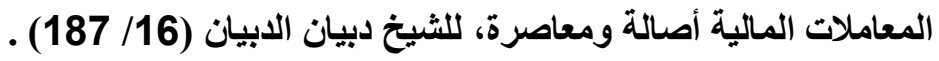
(2) النوازل الوققية، للميمان ص27.

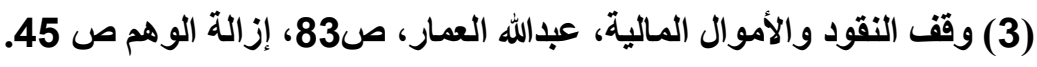


الأرباح التي تحققها العقارات في كثير من الأحيان، والقول بعدم الجواز فيه ضيق وحرج على المسلمين. (1) 4- أن الفقهاء القدامى وإن كان لهم نوع عذر في ترددهم في

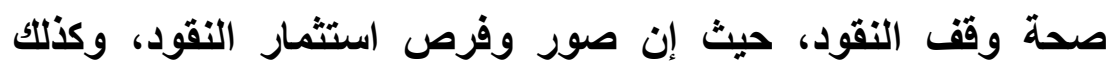
المنافع المتوقعة من وقفها كانت محدودة، ولكن في عصرنا الحاضر

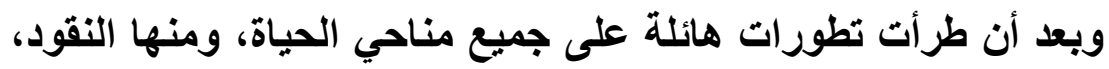
وطرق استثمار الأموال النقلية، وكذللك إدارة الأوقاف، والخدمات

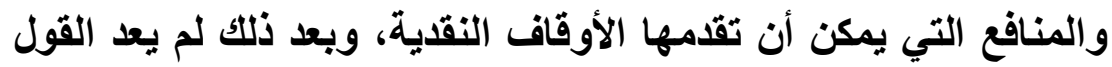

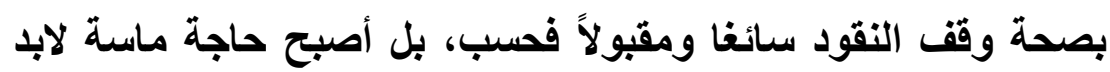
من تلبيتها بخاصة الاوقاف الجماعية التي يمكن أن تقوم بتنفيذ التئي

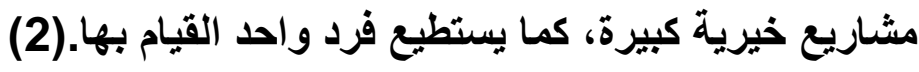

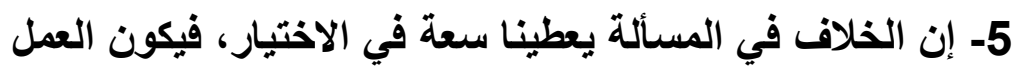
بقول المجيزين هو الأقرب إلى المصلحة الراجحة، بل هي مصلحة

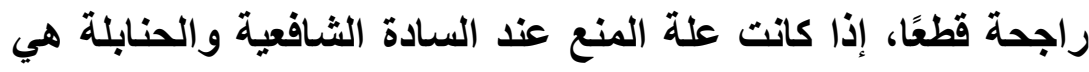

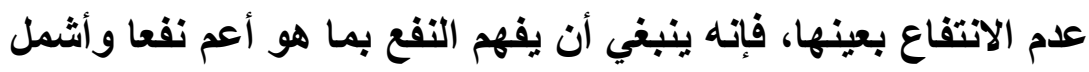

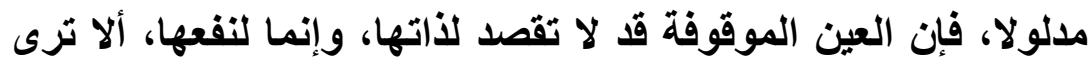

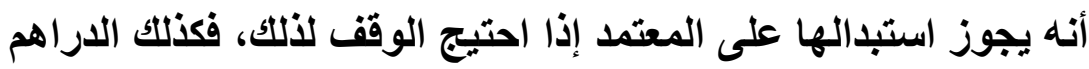

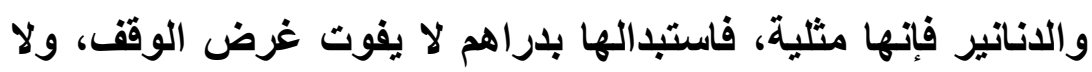

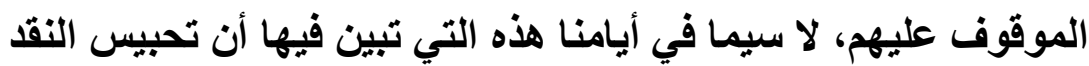

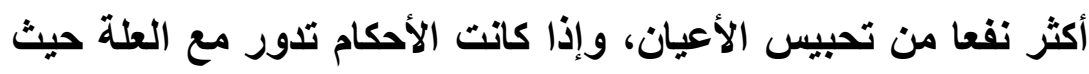

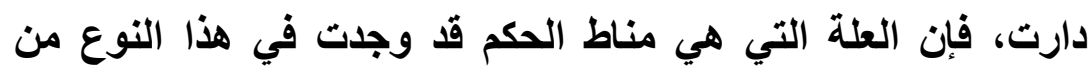
الوقف، فينبغي أن لا يبقى خلاف في المسألة. 6- أنه قد جرى التعامل اليوم في كثير من البلاد بوقف النافي النقود،

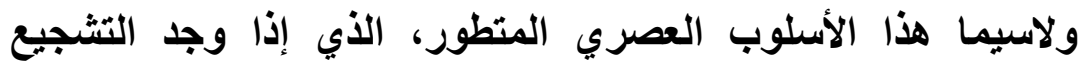

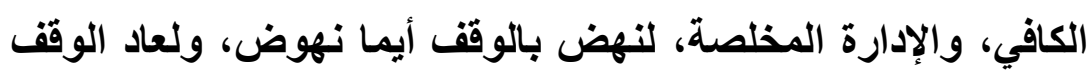


إلى سالف عهده نفعًا ويرًا، كما يدل على ذللك واقع بعض الدول التي اتخذت هذا الأسلوب الوقفي منهجًا لتطوير الوقف كدولة الكويت مثلا

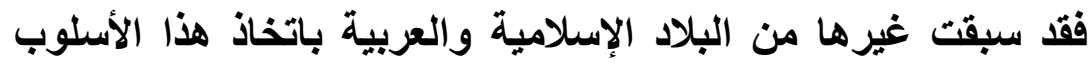

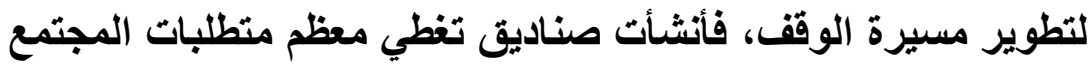

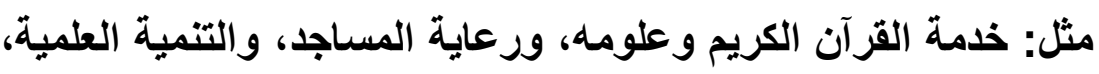

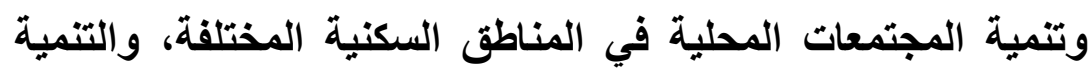
الصحية، والتنمية البيئية، وقضايا الثقافة والفكر، والتنمية الأسرية،

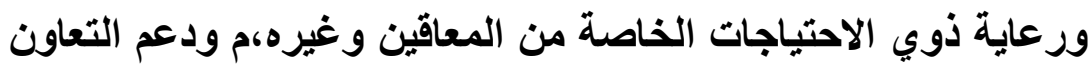

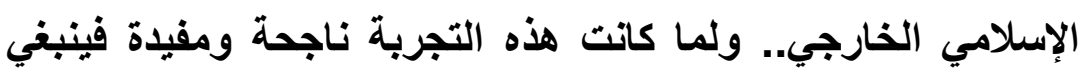

للاول الإسلامية الاحتذاء بها والاستفادة من تجربتها. (1)

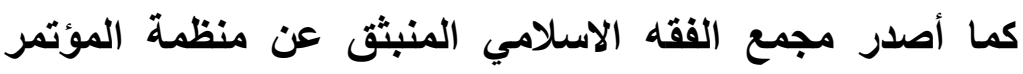

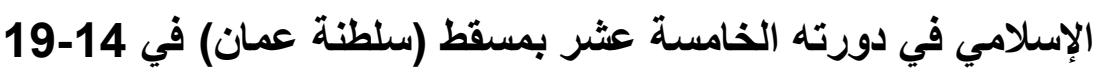

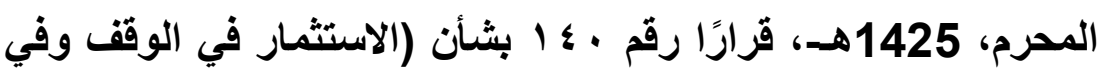

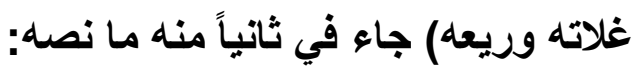

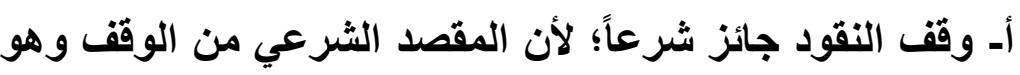

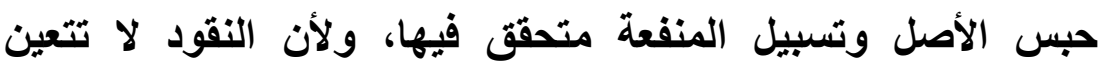

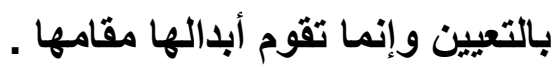

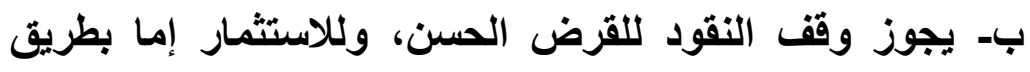

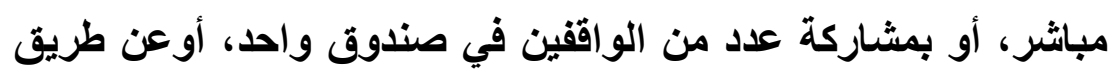

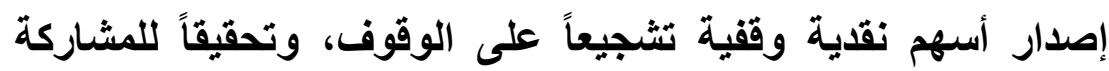

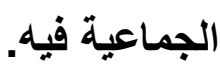

ج- إذا استثمر المال النقدي الموقوف في أعيان، كأن يشتري

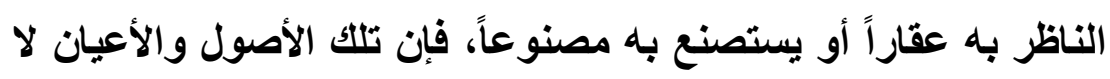


تكون وقفاً بعينها مكان النقد، بل يجوز بيعها لاستمرار الاستثمار،

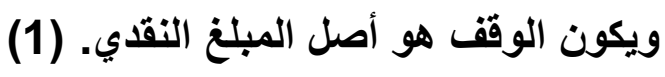

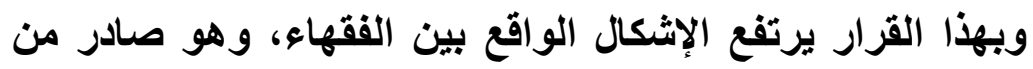

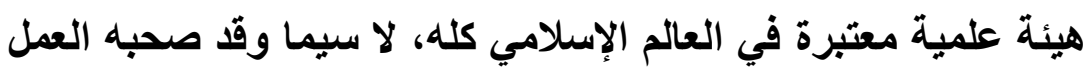

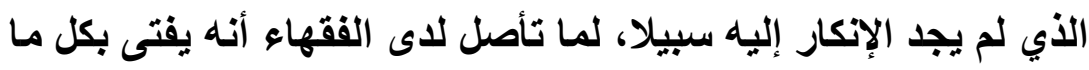

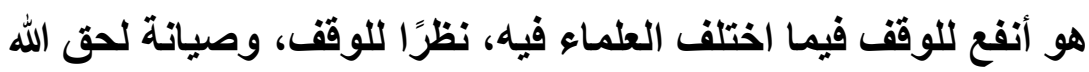

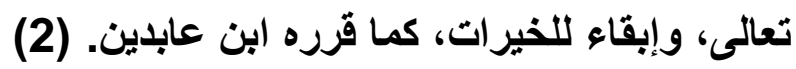

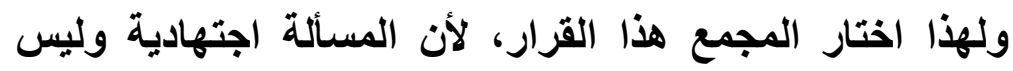

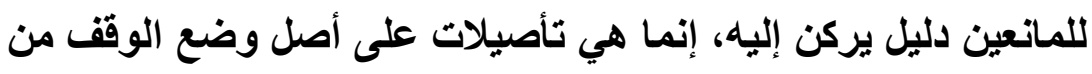

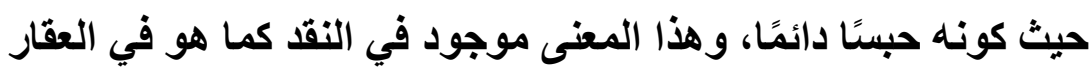

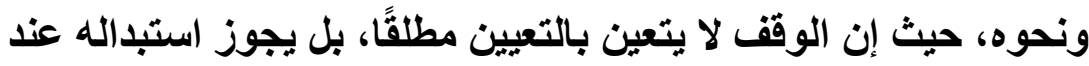

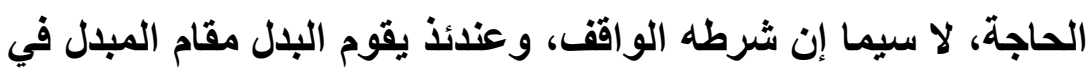

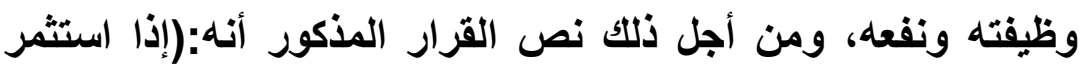

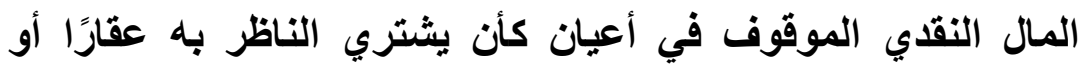

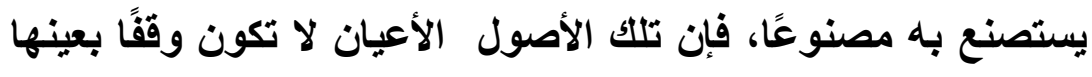
لاستمرار الاستثمار، ويكون الوقف هو أصل المبلغ النقدي) .

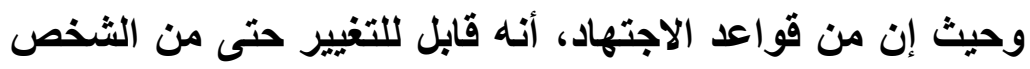

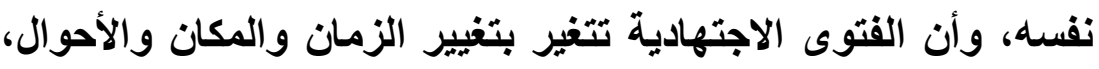

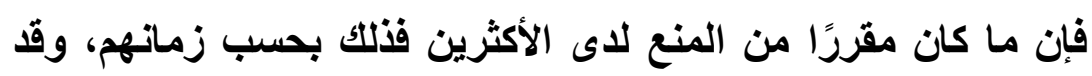

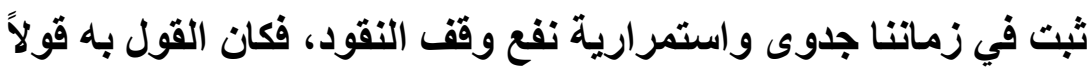

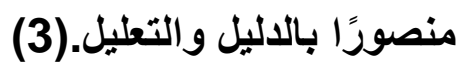

(1) مجلة مجمع الفقه الاسلامي، الدورة الخامسة عشر، العدد الخامس عشر،

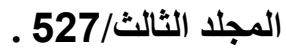

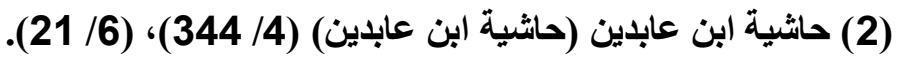
(3) وقف النقود واستثمارها، د. أحمد بن عبد العزيز الحداد ص344) (21/ 
بعد أن رجحنا جواز وقف الدراهم والدنانير، إما لغرض إقراضها

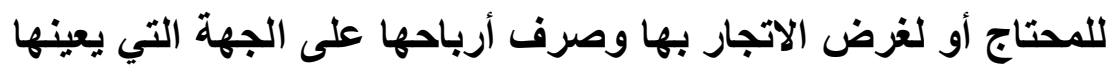
الواقف يبقى أن نبين حكم وقف سائر العملات الأخرى ورقية أو غيرها.

فمما فرضته ظروف العصور المتأخرة، ولا سيما طلب سهولة

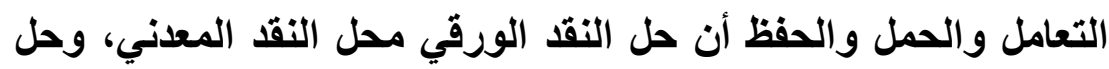

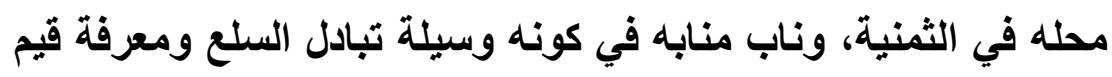
الأشياء، وعلى هذا فكل ما جرى على العملة المعدنية من أحكام فإنها

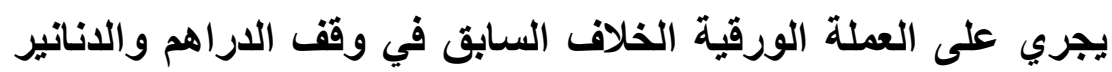
على النقد الورقي.

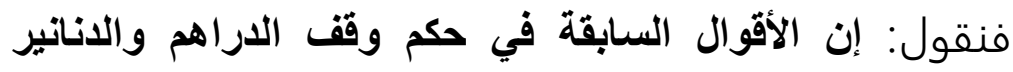

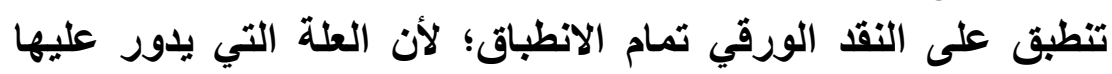

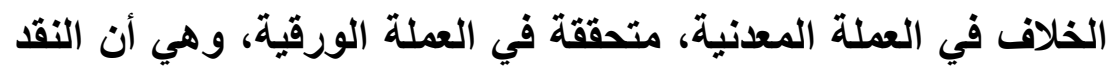

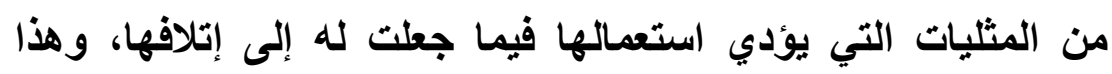

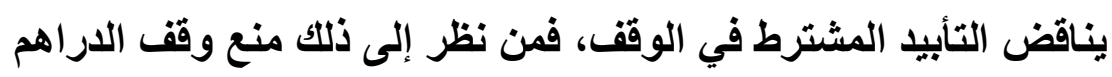
والانانير، وهكا يقتضي منع وقف النقود الورقية، ومن نظر إلى أن الن النئ

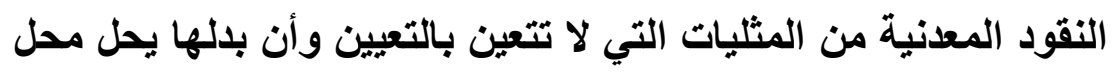

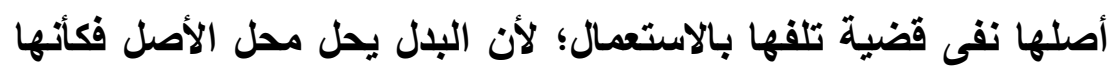
باقية، فلا ينتفي شرط التأبيد في وقفها.

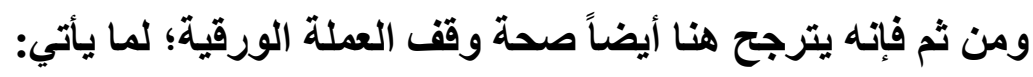

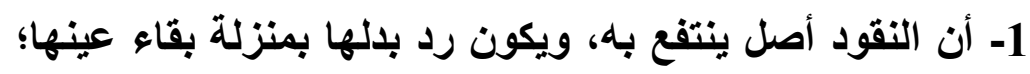

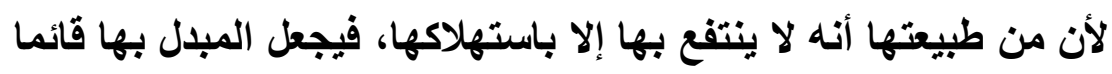

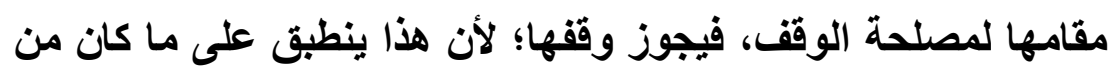

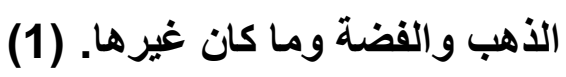
2- إنّ وقف النقود الورقية المعاصرة يكاد يكون أوضح في 
الترخيص من وقف النقود المعدنية القديمة، كالدرهم والدينار، من

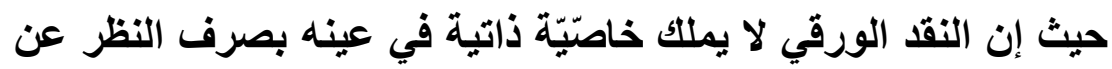

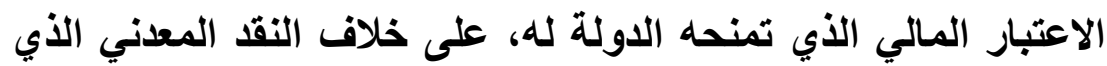

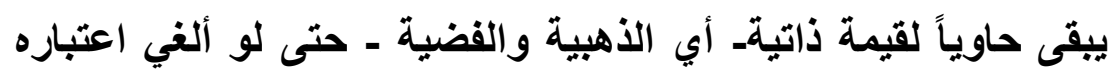

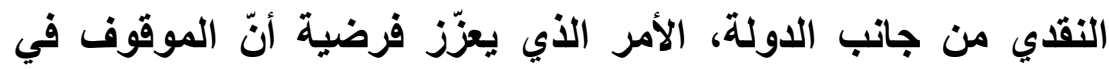
النقد الورقي محض الاعتبار المالي، لا العين، حتى يناقش بأنه ممّا

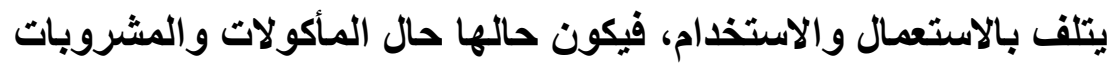
التي حكموا في الققه الإسلامي بعدم صحّة وقفها.

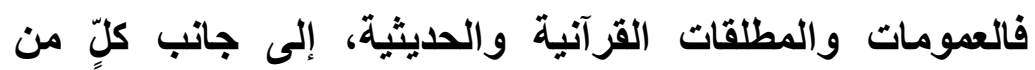

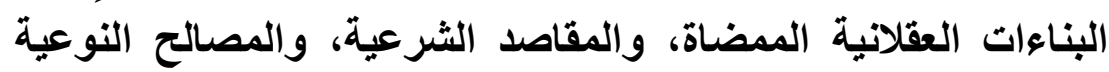
الكامنة في الوقف النقدي، مع عدم وجود نصوص حاسمة في الصدور

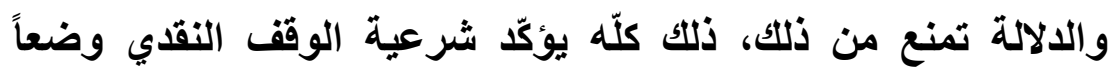

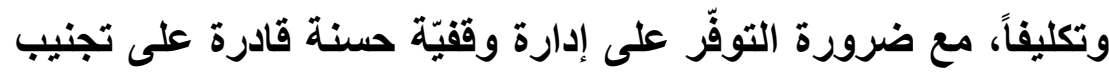

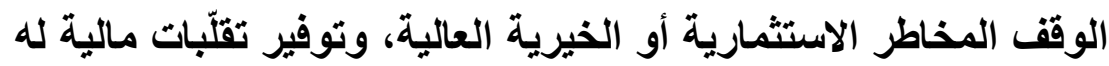
تزيد أو تحافظ على قدرته المالية. 3- إنّ الترخيص في الوقف النقدي لا يواجه الوقف الوقله العيني، بل يظلان

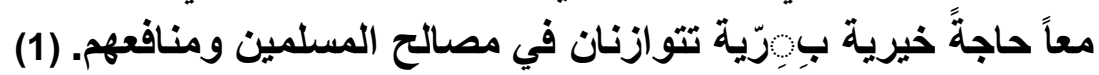

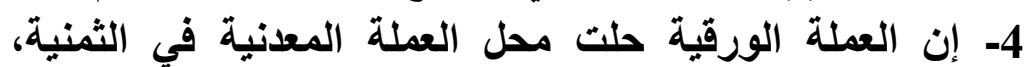
فأصبحت تنوب منابها في كل ما كاتت توظف له من معرفة قيم الأشياء وتبادل السلع وغير ذلك. 5- إن النقود الورقية كالنقود المعدنية في كونها من المثليات التي

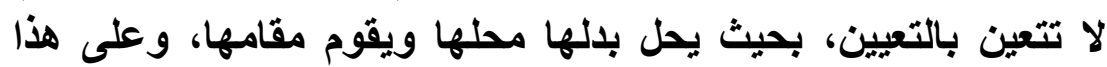

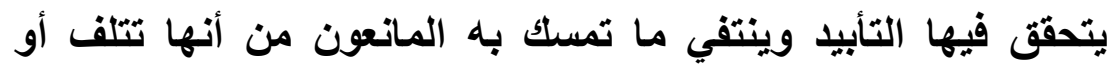
تستهلك بالاستعمال، وهذا هو ما قرره كثير من الفقهاء كما سبق بيانها تمانه

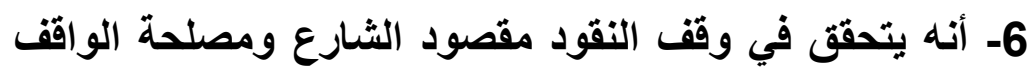
والموقوف عليه، فيتحقق مقصود الشارع بوقف مال يستثمر مع بقائه، ويصرف ربحه في أعمال البر ومصلحة الواقف، بفتح باب منوف من أبواب 
الوقف المتيسر له؛ إذ ليس كلّ يملك عيناً يمكن وقفها، وقد لا يستطيع شراء عقار ونحوه ليوققه، وهكذا يتحقق مصلحة الموقوف عليهم بفتح

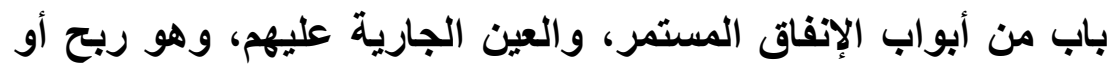

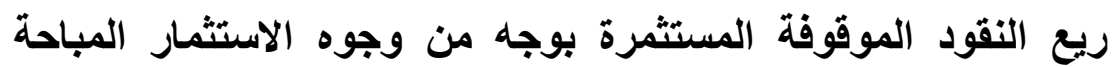

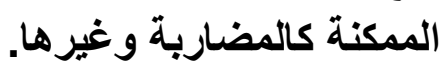

7- أن القول بجواز وقف النقود يفتح الباب أمام أصحاب النقود القليلة لوقف ما يقدرون عليه من نقود، عن طريق فتح باب المساهمة

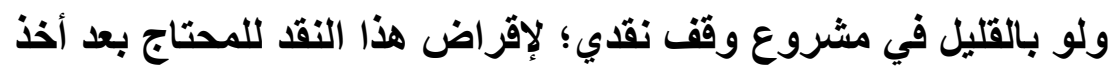

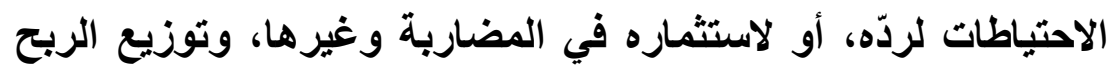

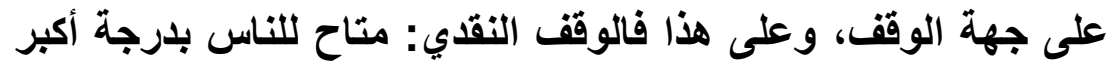

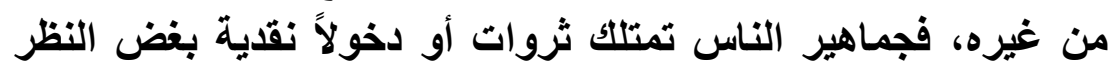

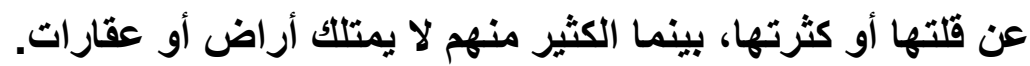

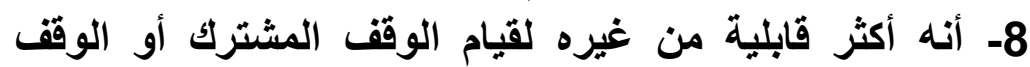

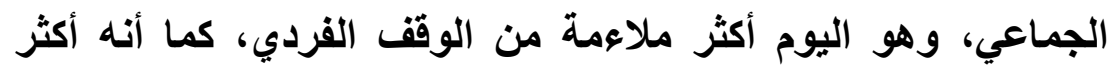

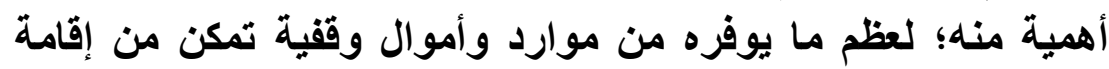

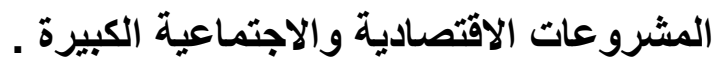

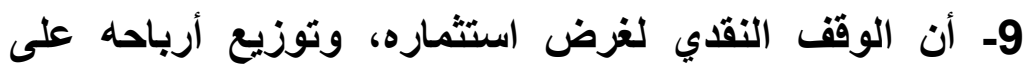

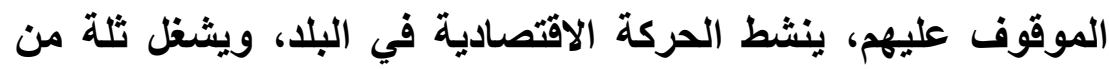

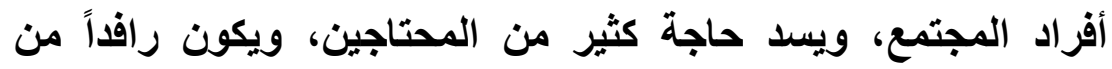

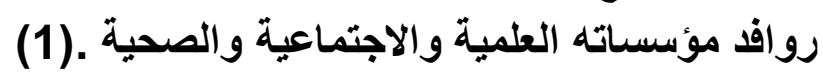

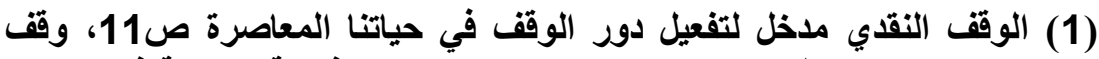

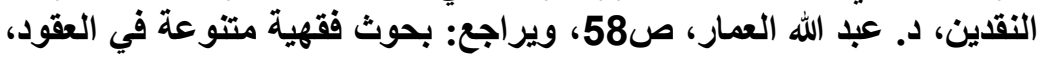
د. عبدالعزيز الحجيلان (صبلمار، د119) . 


$$
\text { المطلب الثاني }
$$

وقف النقود وتغير قيمة النقد

هناك بعض المسائل المتعلقة بوقف النقود ينبغي بيانها، وهي كالاتي:

الفرع الأول: مصادر تحديد قيمة الأوراق النقدية: لا تمتلك الأوراق النقدية أبي قيمة ذاتية(1)، غيدة فير الاوراق أن هذه الأوراق

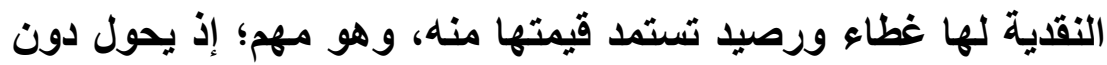
الاسراف في إصدار هذه الأوراق.(2) وقد مرث الأوراق النقدية ـ من حيث غطاؤها الأقدي - بثثلاث

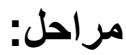
المرحلة الأولى: نظام الغطاء المعدني الكامل:

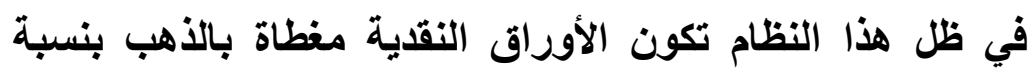
100٪، وعلى وفق هذا النظام تطلق تسمية الأوراق النقدية النائبة.

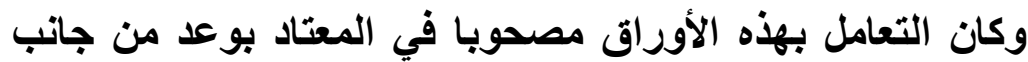

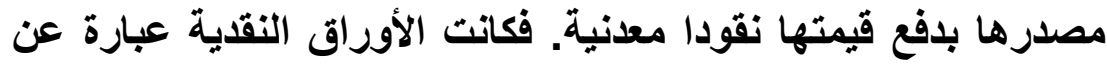

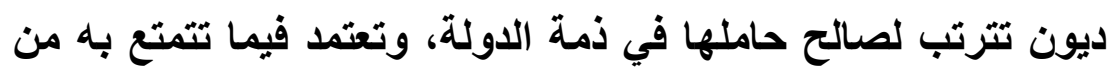

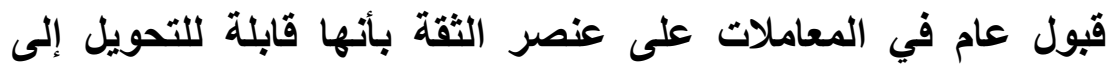

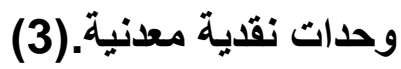
غير أن السلطات النقدية رأت في هذا النظام جمودا لا يتفق وسياستها النقدية، ففي ظل هذا النظام لابد أن تقابل الورقة النقات النقدية

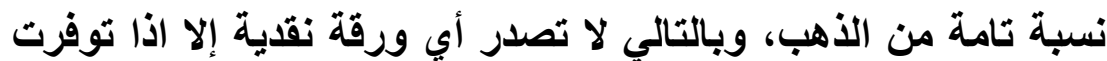
عند الدولة كمية من الذهب تقابلها، فانتقلت إلى النى النظام الثاني.

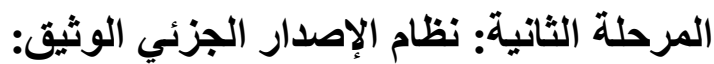

(1) المصارف الأسلامية ضرورة حتمية، محمود محمد بابلي، ص18، الأبنائ، النقود

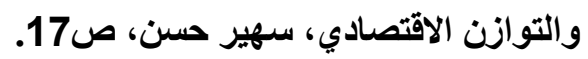

(2) النقود والسياسة النقدية في الاقتصاد اليمني الحديث، عبد العزيز القطري، ص صل 


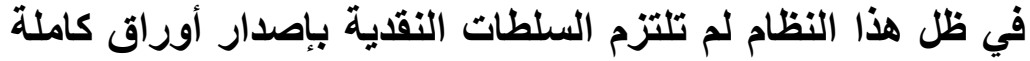
الغطاء، بل إن الغطاء النقدي يشتمل على الذهب إضافة إلى السندات

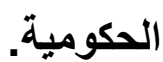

فتصدر السلطات النقدية أوراقا نقدية مقابل السندات الحكومية، وما زاد عن ذلك يحتم غطاؤه بالذهب. وقد وفر هذا النّا النظام مرونة،

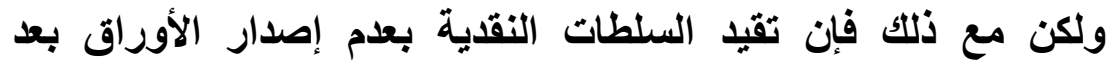

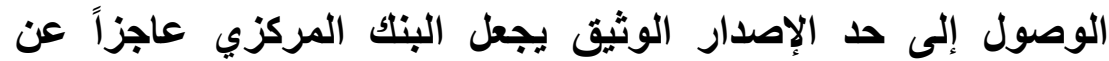
الاستجابة إلى الزيادة في الطلب على النقوده، مما أدى إلى البحثث عن عن عن

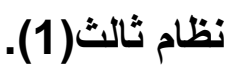

على أن النظامين الأول والثاني لا وجود لهما اليوم. (2)

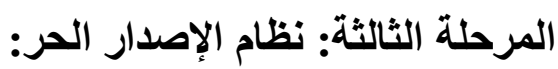

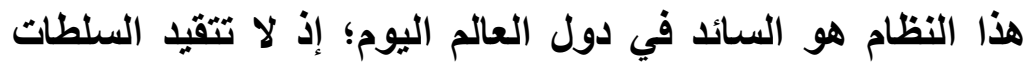

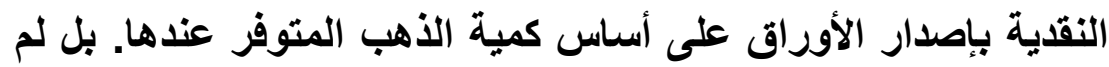

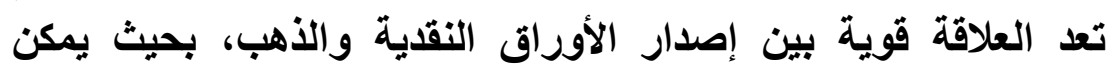

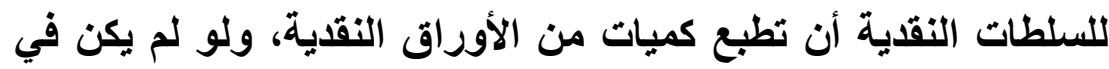
خزينتها مثقال من ذهب. ويموجب هذا النظام تنوعت مصادر الغطاء إلى الآتي:1- الذهب: ما زال الذهب يستخدم كاحتياطي في البنوك المركزية،

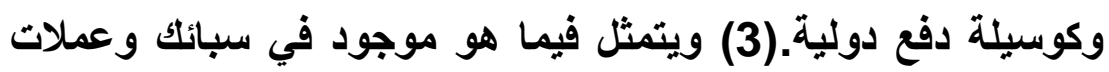

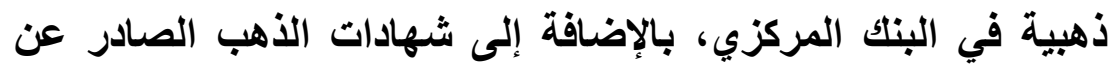
الحكومة، وذلك عندما تثتري الحكومة الذهب من الأفراد مقابل شيك الإبك مسحوب عليها من البنك المركزي، ثم تقوم الحكومة ببيع شهادات التئرات

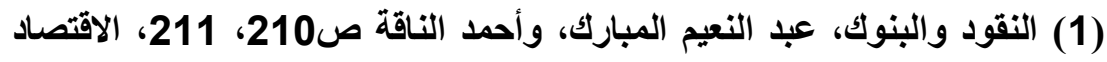

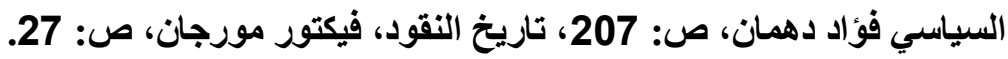

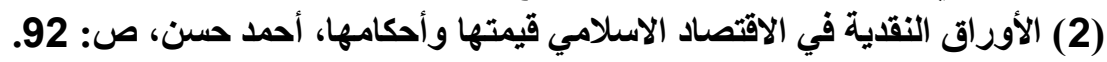

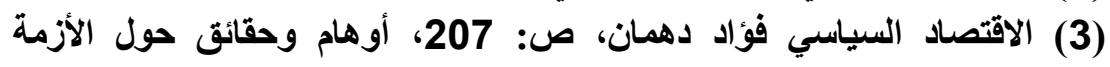

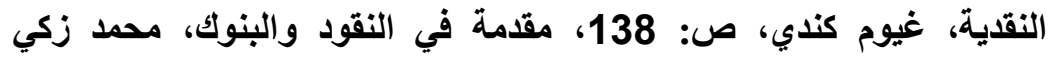
شافعي، ص: 46، الأوراق النقدية في الاقتصاد الإسلامي قيمتهن ولنها وأحكامها،

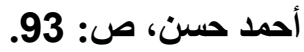


الأهب للبنك المركزي، وهكا يصدر البنك المركزي مزيدا من الأوراق

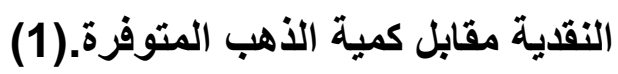
2- العملات الأجنبية: والمقصود بها تلك العملات القوية كالدولار الأمريكي واليورو والين الياباني والجنيه الإسترليني وغيرها، وهي تعد

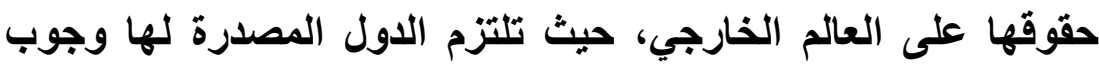
الوفاء بها تجاه من يملكها، وأهم مصدر لهذه العملات هو عمليات

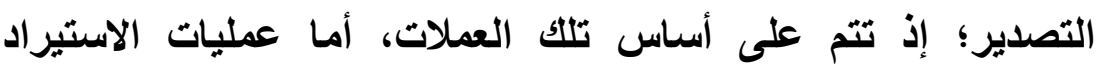
فتستنزف هذه العملات.

3- حقوق السحب الخاصة: هي أداة ائتمانية ذات صفة دولية(2)، أنشأها صندوق النقا الدولي(3)، وهي نظام خاص لتوليد السيولة، سمي بحقوق السحب الخاصة، تستخدم كوسيلة لتسوية الديون بين البنوك المركزية(4). وهكذا يقدم الصندوق للاول الأعضاء نقا أجنبيا

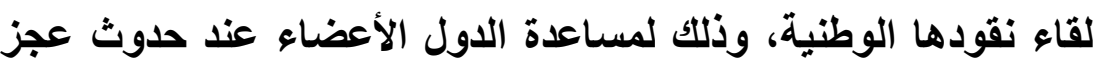
في ميزانيتها.

4- الأوراق المالية الحكومية: من العناصر التي تزيد في القاعدة النقدية شراء البنك المركزي الديون الحكومية مباشرة أو بصورة غير

(1) النقود والبنوك والاقتصاد وجهة نظر النقييين، باري سيجل، ص: 227،

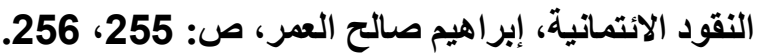

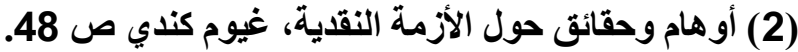

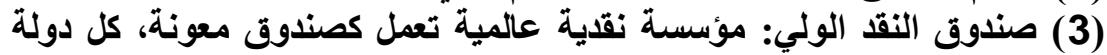

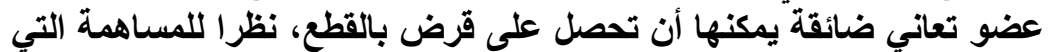

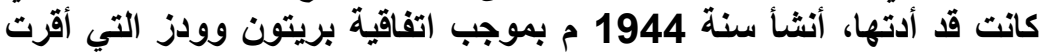

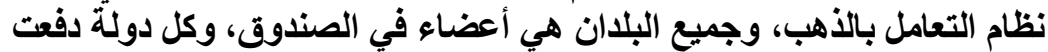

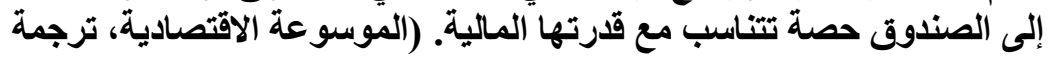

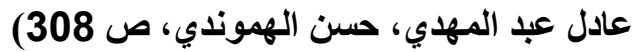

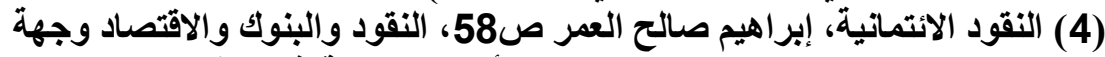

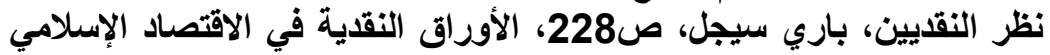
قيمتها وأحكامها، أحمد حسن، صون. صناري 
مباثرة للأوراق المالية الحكومية بهاف إلغاء الأثر السلبي على أسعار السندات والتي تتتج عن بيع أذون الخزانة(1) بكميات كبيرة . وهكذا يقوم البنك المركزي بزيادة العرض النقدي مقابل هذه السندات، فتصبح هذه السندات هي الرصيد المقابل للإصدار النقدي.

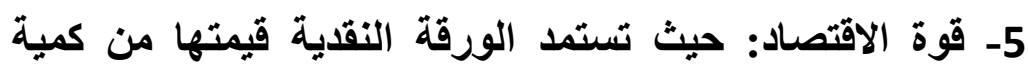

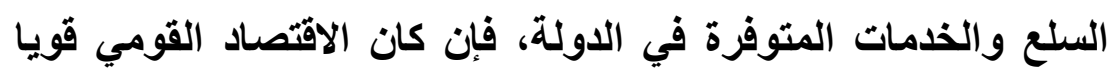

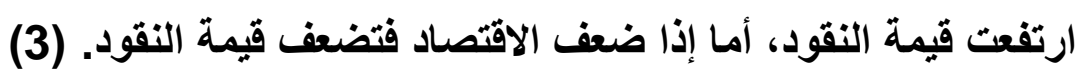

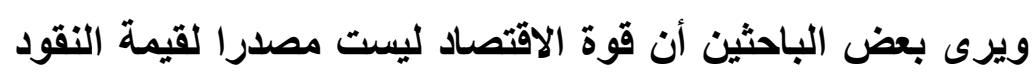
في حد ذاتها، وهي لا تفيد إلا في ناحيتين:

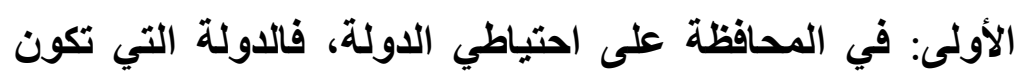
وارداتها أقل من صادراتها تبقى نقودها قوية من حيث القوة الثرائية.

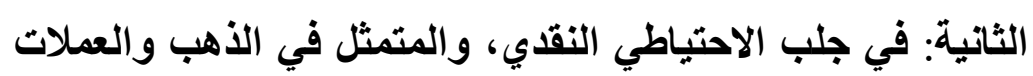

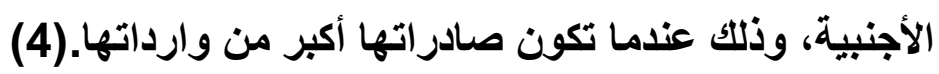

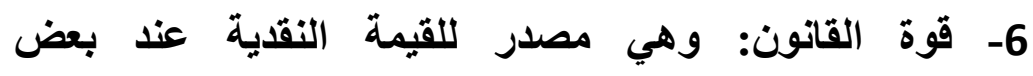
الاقتصاديين(5)، وهو محل نظر؛ لأن قوة القانون ينحصر دورها في لفئن

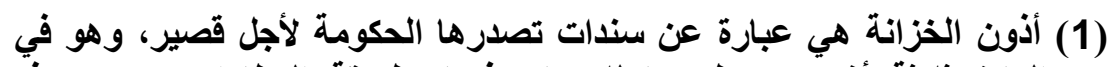

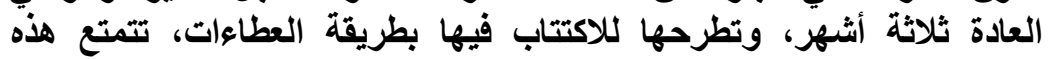

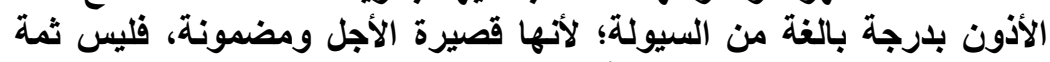

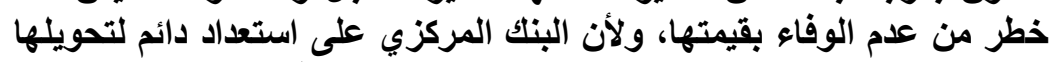

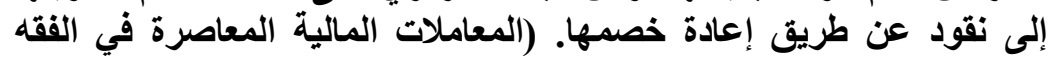

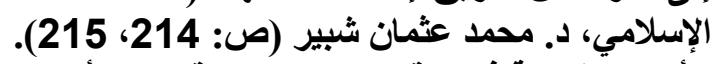

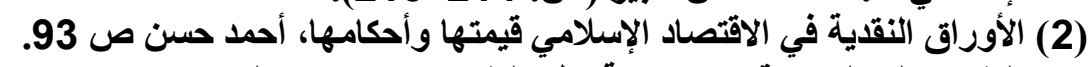

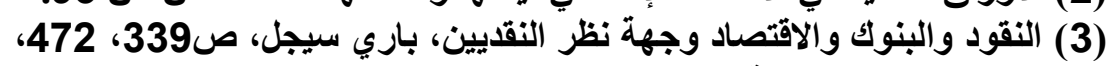

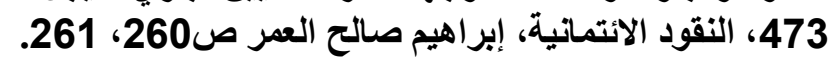

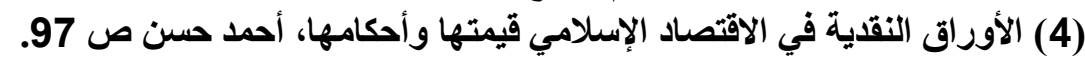

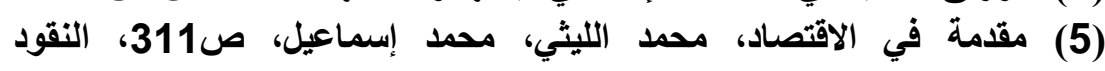

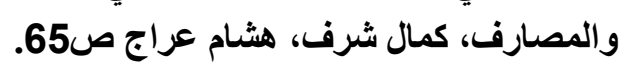


إلزام الناس بقبول الأوراق النقية وإعطاؤها الصفة القانونية النهائية

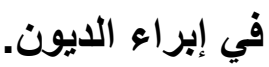

أما القوة الثرائية للأوراق النقدية فتستمد من عناصر التظطية المذكورة، ولا يمكن للقانون أن يططي للأوراق النقلية أية قيمة

حقيقة. (1) مدكورة

هذه هي المصادر التي تكون قيمة النقد، كما أن هذه المصادر

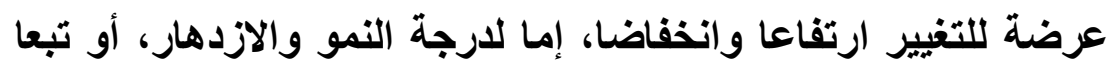
للانكماش و التردي لاقتصاد ذلك البلا. الفرع الثاني: أثر تغير قيمة النقد على قيمة الأصول النقية الموقوفة. يختص وقف النقود دون سائر الأموال بتأثر رأس المال مباثرة الثرة

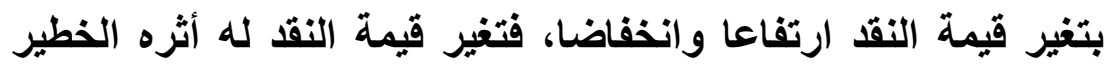

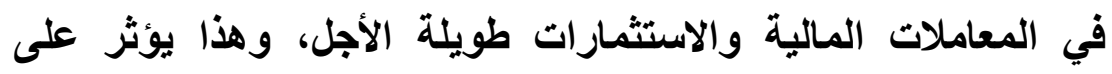
الوقف الذي ينبغي فيه التأبيد. فكان ثُمة تساؤل يتبادر إلى الذهن، وهو: ما مدي تأثر تغير قيمة

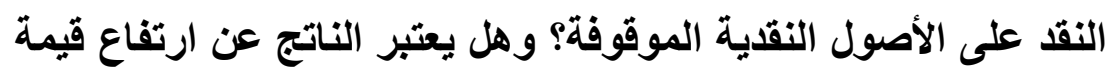
النقد من الأصل الموقوف أو يعتبر من الريع؟ وهل يعتبر نقص قيمة الفئ

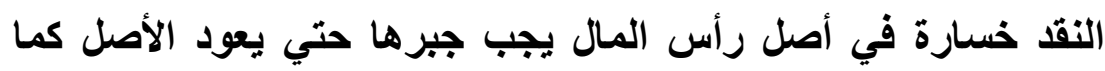

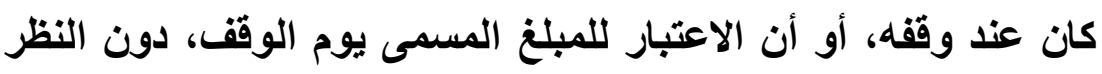

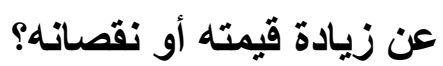
فلو افترضنا مثلا أن رجلا وقف عثرة ألاف جنيه وبعد وقت

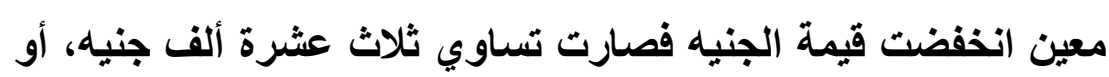
ارتفعت قيمة الجنيه فأصبحت تساوي تسعة آلاف، فهل يعتبر أصل 
الوقف قيمة النقا يوم الوقف (العشرة آلاف جنيه) أو القيمة الجديدة

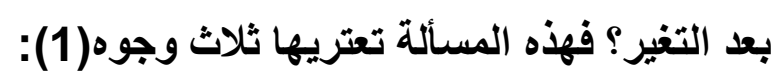

فأما الوجه الاول: هو اعتبار المبلغ المسمى يوم وقفه أصلا فإنه وإن كانت فيه مراعاة لفظ الواقف، إلا أن فيه جمودا غير لائق بمسايرة التغيرات، وتجاهلاً لمقتضيات الواقع، واجحافا بحق الوقف،

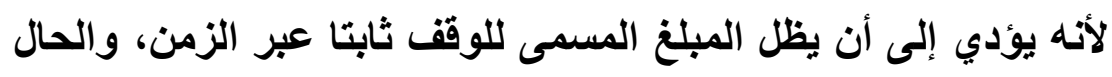

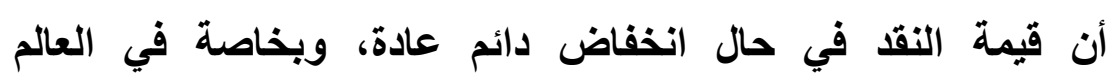
الإسلامي، مما يجعل الوقف شبه متعطل وعديم الجدوى بعد مرور عدة

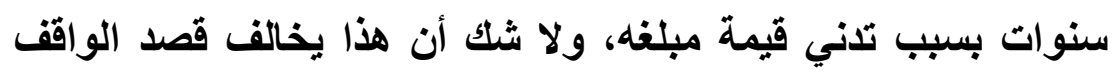
من تأبيد الوقف وبقاء منفعته، وهناك قاعدة فقهية تقول: إن قصد

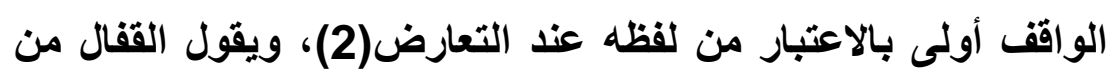

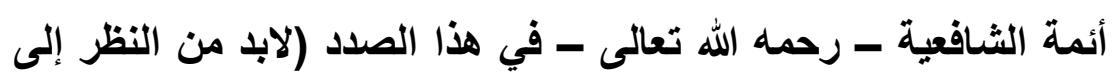

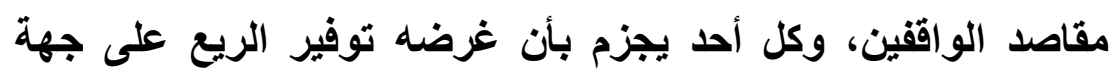

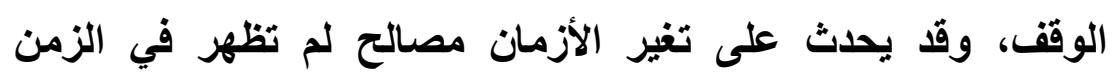

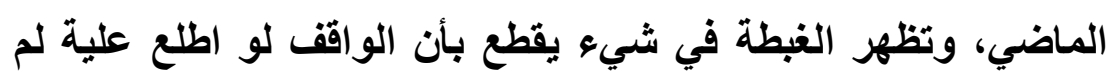

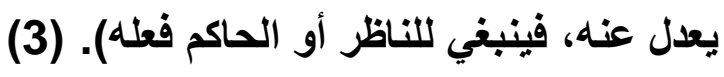

(1) النوازل الوقفية، ناصر الميمان، ص32.

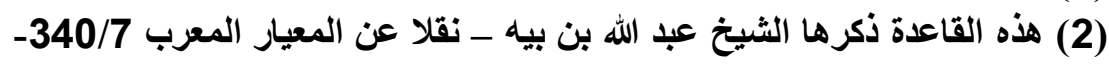

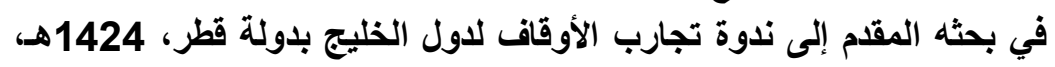

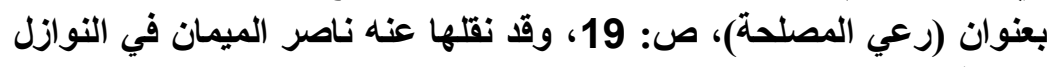

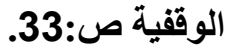

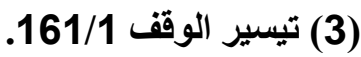


أما الوجه الثاني: وهو اعثبار القيمة أصلا مطلقا ـ فإنه وإن كان يساير المتغيرات، إلا أن فيه تجاهلا تاما للفظ الواقف من جهة، وتجاهلا لمصلحة الوقف من جهة أخرى في حالة ارتفاع قيمة النقد، فإن مصلحة الوقف تقتضي الحفاظ على أعلى مبلغ ممكن لرأس مال الوقف، بشروطه .

وأما الوجه الثالث: فإنه يعني أن يرفع المبلغ المسمى إلى ما يساوي قيمته، عند انخفاض الأسعار، ويبقى على حاله، ولا ينقص عن المسمى عند ارتفاع قيمة النقد.

وحيث إن المسألة اجتهادية، والاجتهاد يقتضي في هذه المسائل مراعاة الصالح للوقف والموقوف عليهم فالذي يظهر لي اختياره- هو الوجه الثالث؛ لأن فيه مراعاة مصلحة الوقف على الوجه الشرعي بناء على قول أحد الفقهاء في أنه (يفتي بكل ما هو أنفع للوقوف فيما

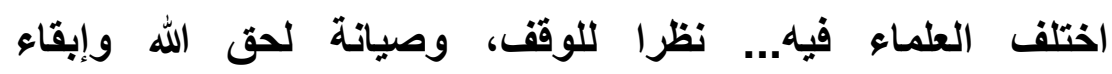

(2) (1) (1) (1) (1)

344/4 (1) حاثية ابن عابدين (2) (1) النوازل الوققية، ناصر الميمان، ص35. (15) 
الفرع الثالث: حكم تحديد مخصصات(1) لمواجهة تغير قيمة النقد:

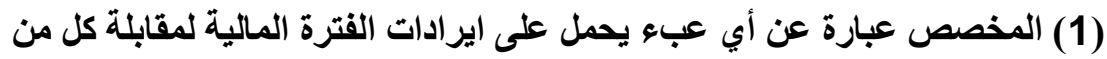

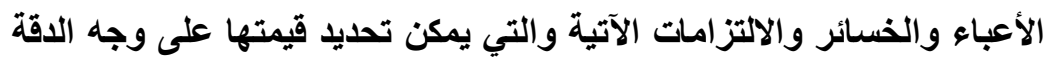

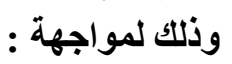

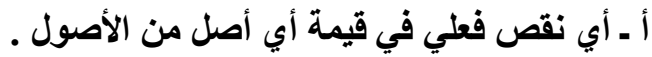

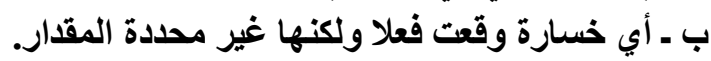

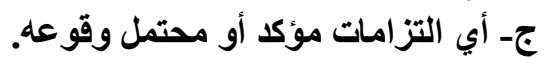

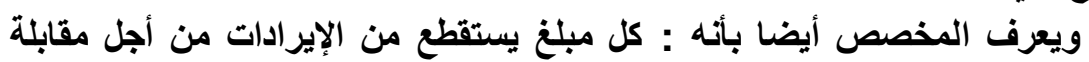

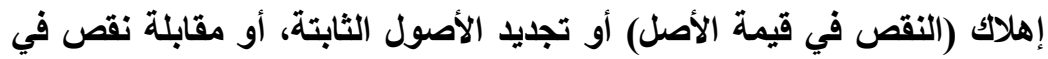

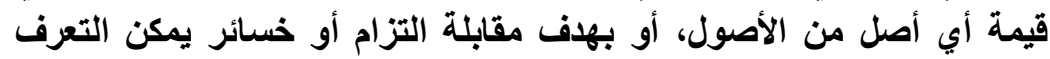

$$
\text { عليها ولا يمكن تحديد قيمتها بدقة الأبول }
$$

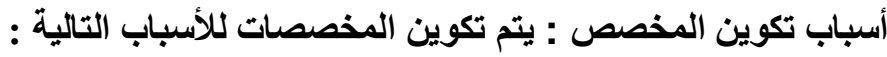

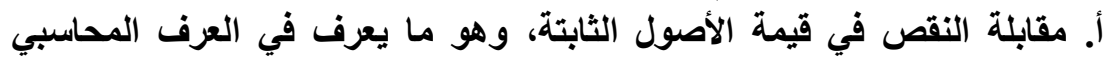

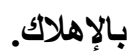

ب- مقابلة تجديد الأصول الثابتة .

ج- مقابلة النقص المؤكد الداوث في قيمة الأصول والذى يمكن التعرف عليه، ولا يمكن تحديد قيمته بدقة، مثل مخصص الدئة الديون المعدومة.

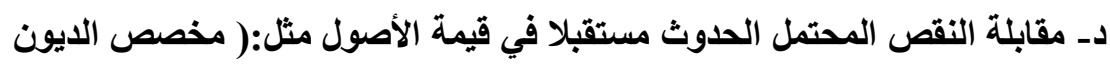

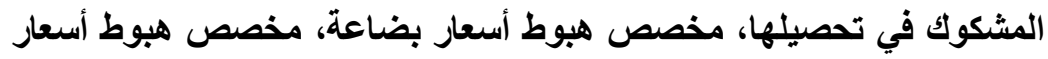

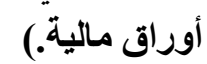

هـ. مقابلة التزامات مؤكدة يمكن التعرف عليها ولا يمكن تحديد قيمتها بدقة، مثل :

$$
\text { (مخصص الضرائب). }
$$

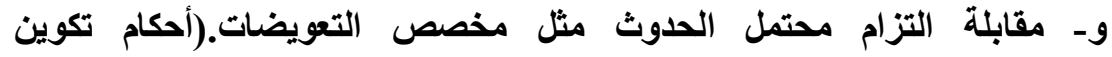

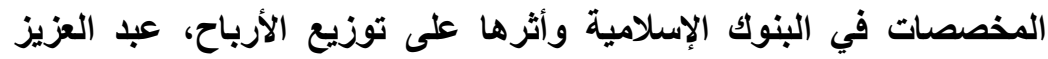

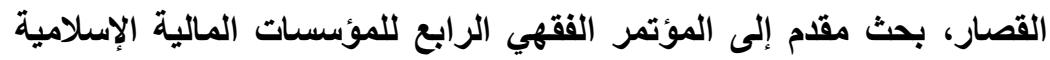

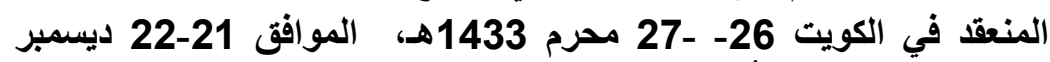

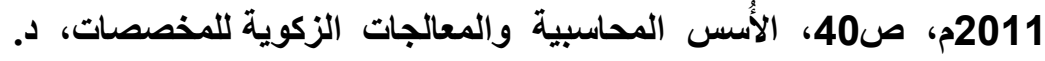

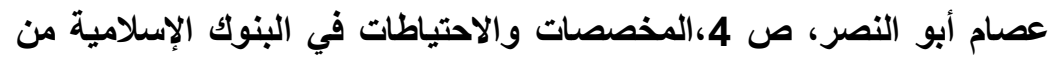
منظور فقهي ـالطيب مبروكي ص 23). 
إن تأبيد الوقف لاستمرار عطائه يوجب بقاء الأصل الموقوف في حالة صالحة، بالمحافظة عليه، حتى يضمن بقائه و استمراه، لمصلحة الو اقف و الموقوف عليهم. فيجب على ناظر الوقف، سواء كان الواقف أو غيره، وسواء كان

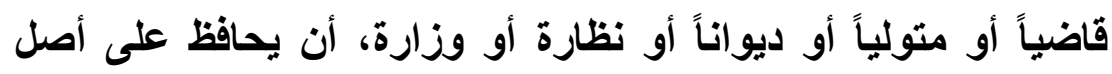

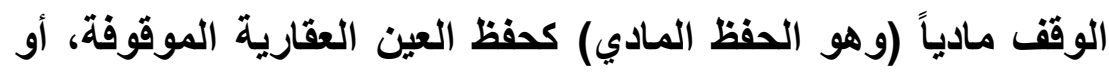

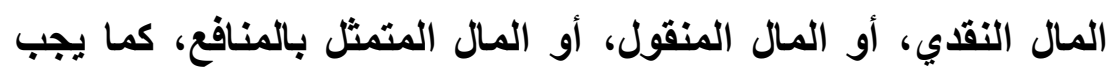
عليه حفظ وثيقة الوقف التي تم توثيق الوقف بها (وهو الحفظ المال

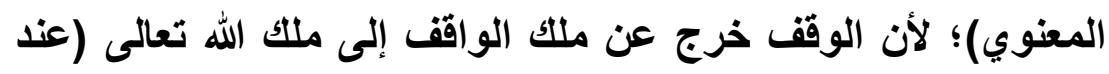

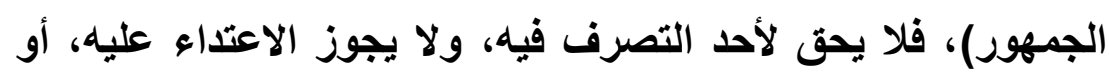
الغصب، أو وضع اليد، إلا بطريق شرعي مأذون فيه(1).

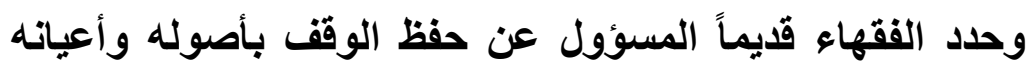

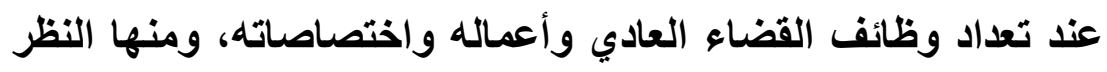

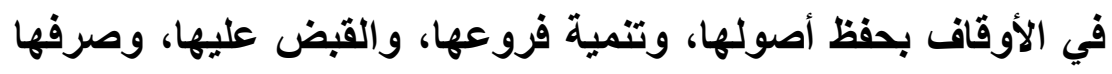

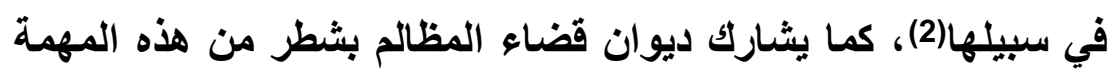

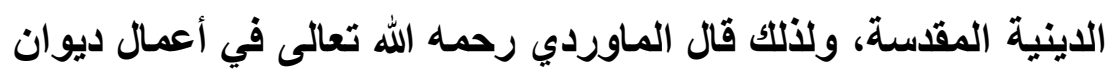

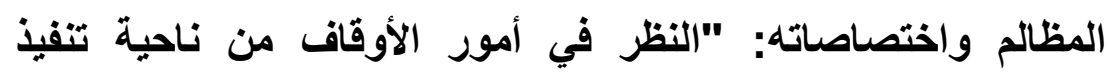
شروطها، ويناء الخراب منها، ومحاسبة النظار عليها" (3).

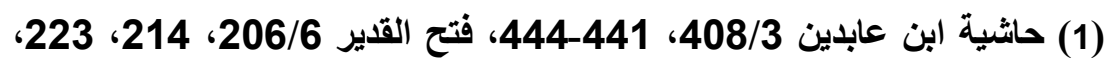
روضة الطالبين 348/5، الفقه الإسلاهي وأدلته 214/8، 234 234، الوقلت ودوره

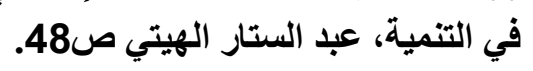

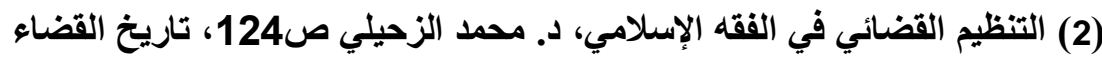

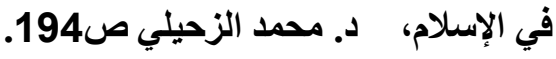

$$
\begin{aligned}
& \text { (3) الأحكام السلطانية، ص77، } 80 .
\end{aligned}
$$


وكان القاضي توبة بن نَمِر(1) الذي تولى قضاء مصر سنة

115هـ أول قاض تسلم الأحباس (الأوقاف) في زمن هشام بن تئ عبد

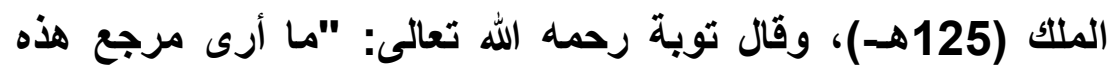

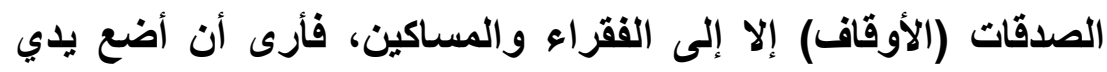

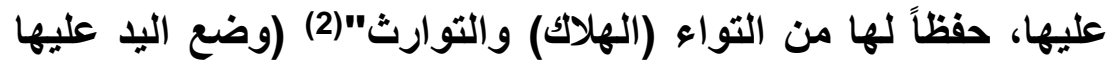

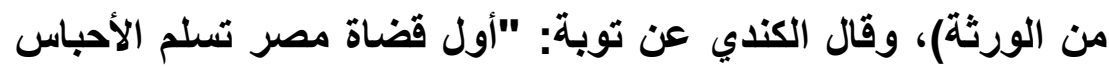

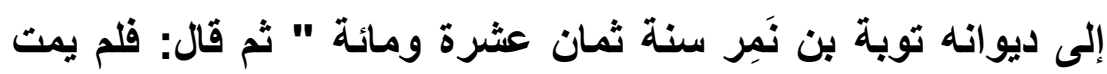

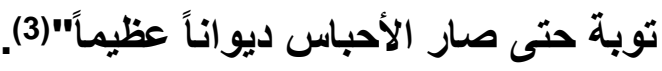
كذلك يجب على الناظر عمارة الوقف وصيانته، فالحفظ المادي للوقف ـ الواجب على الناظر - يقتضي شرعاً وعقلاً واقتصادياً عمارته وصيانته، وقد نص على ذلك الفقهاء. قال النووي رحمه الله تعالى:

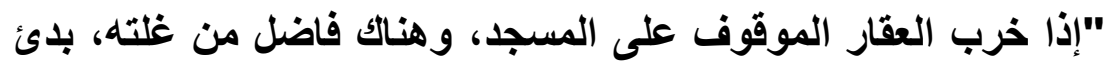
به بعمارة العقار"(4)، فيقام بقاء العين الموقوفة على حقى العقدئ المستفيد

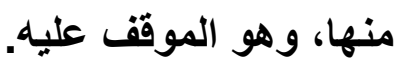

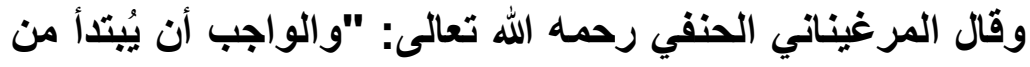

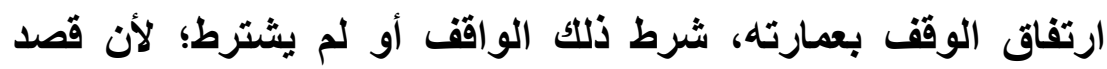

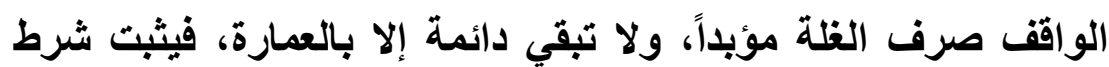

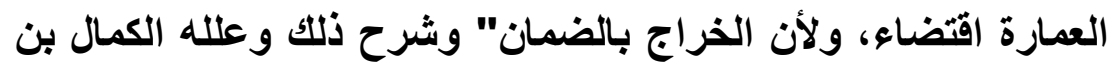

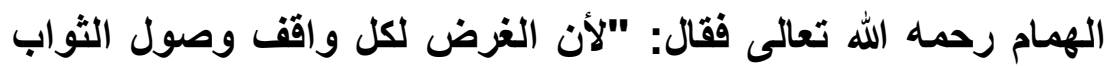

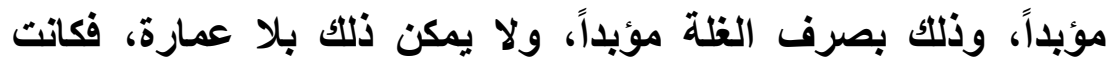

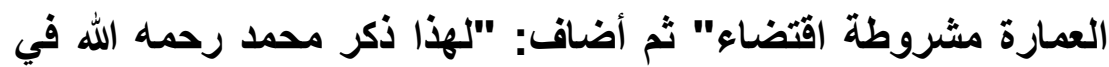

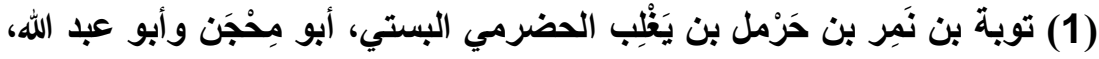

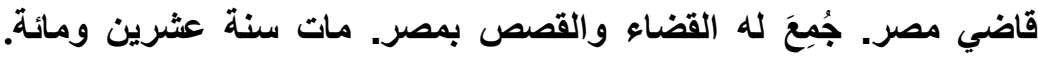

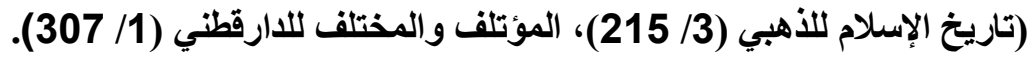

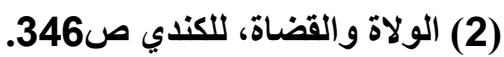
(3) المرجع السابق، وانظر: تاريخ القضاء في الإسلام، د. محمد الزحيلي،

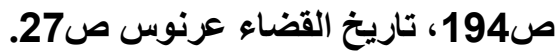
(4) روضة الطالبين 359/5، وانظر: المهذب 27 ع89/3، البيان 100/8. 
الأصل في شيء من رَسْمِ الصُكُكُكِ: فاشتُرط أن يرفع الو الي من غلته

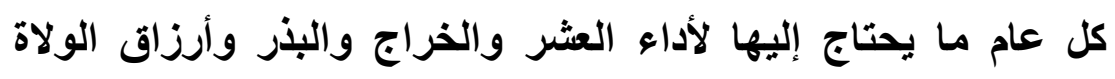

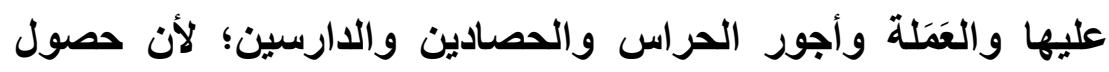

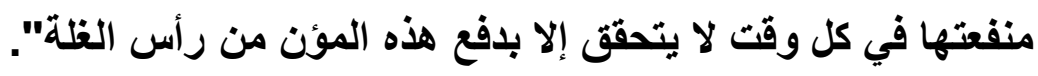

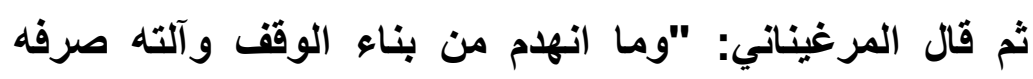

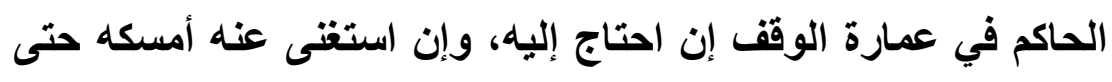

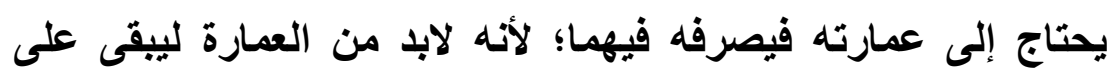

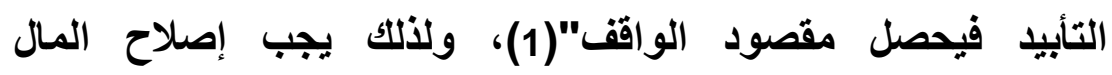

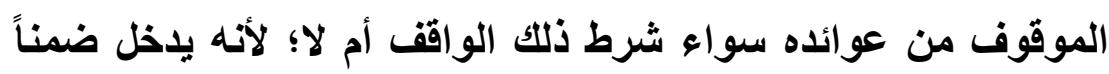
في نيته بتأبيد الوقف. لذلك قرر الفقهاء وجوب الإنفاق من ريع الوقف على عمارته

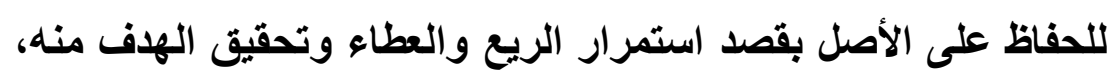

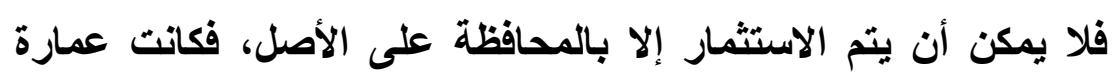

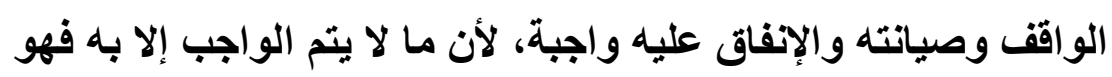

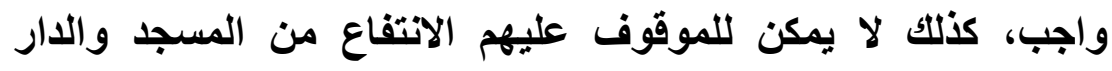

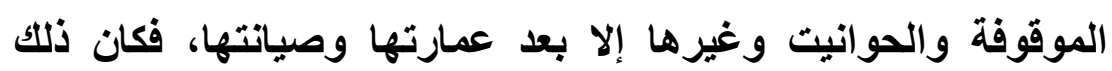
واجباً، لتوقف الانتفاع عليها.

حتى قال الفقهاء بتقليم الإنفاق من ريع الوقفال على عمارة

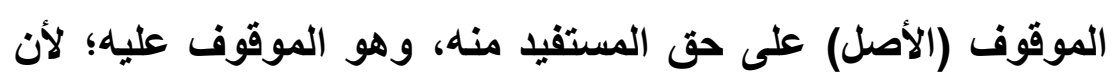

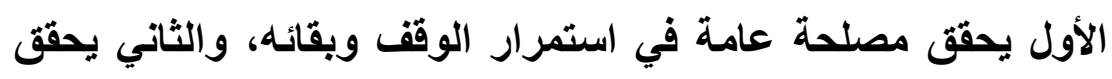
مصلحة خاصة للموقوف عليه، ومن القواعد الفقهية المقررة: تقديم العايم المصلحة العامة على المصلحة الخاصة، فتكون الأولوية في إنفاق القئ

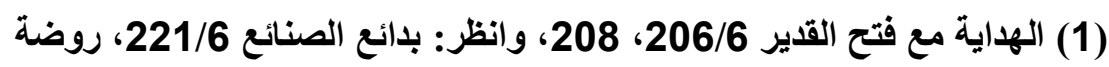

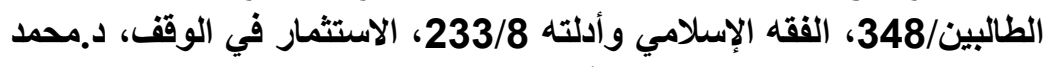

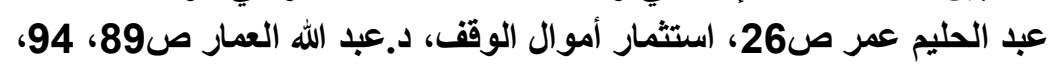

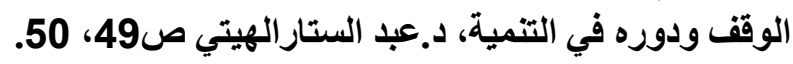


عو ائد الوقف على إصلاح هذه الأموال والإبقاء عليها، ليستمر عطاؤها

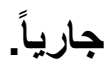

و هذا ما أكده الكاساني رحمه الله تعالى فقال: "والواجب أن يبدأ

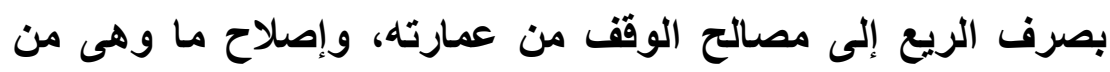

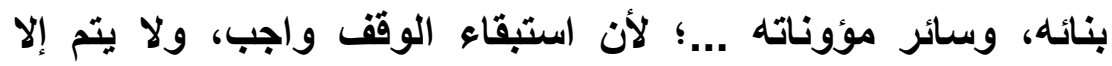

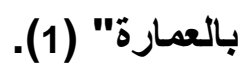

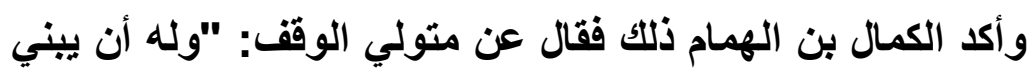

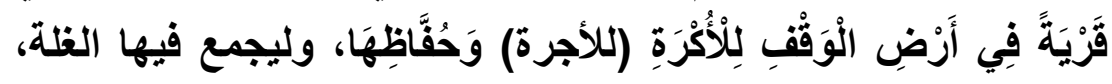

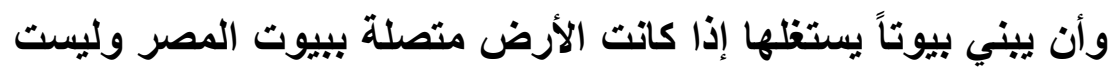

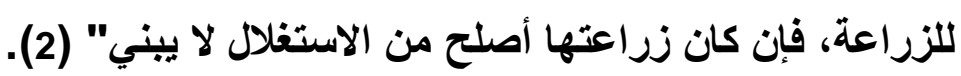

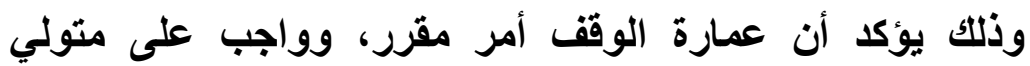

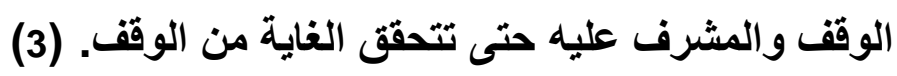

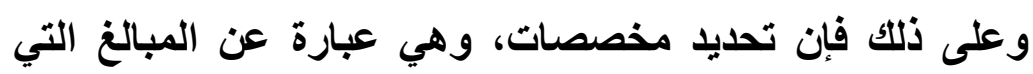

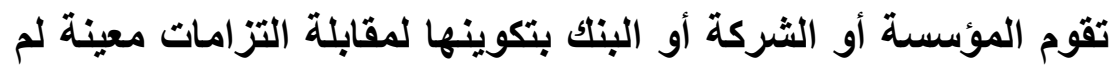

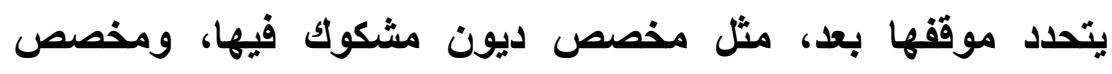

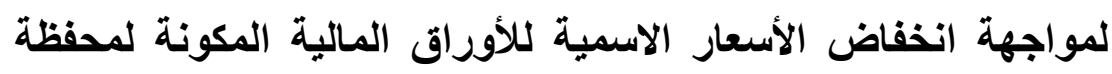

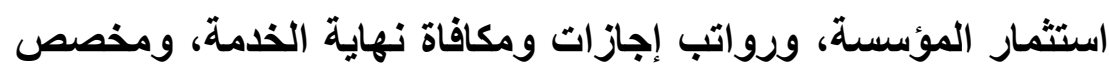

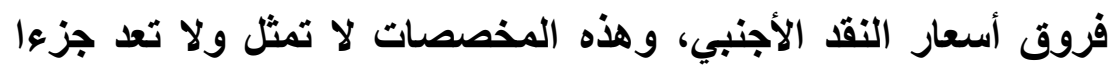

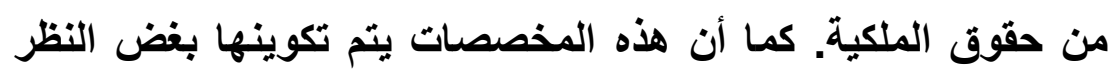
عن الربح والخسارة للبنتك. (4).

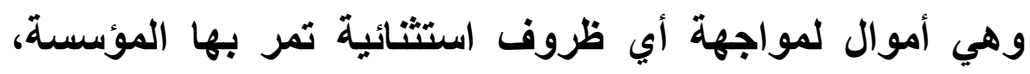

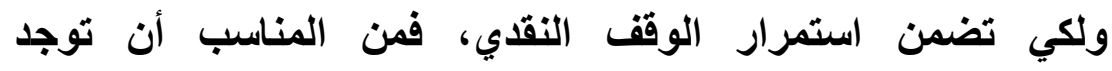
مخصصات لتغير قيمة الوقف النقدي، بحيث يكون هذا المخصص مقدرا

221/6 (1) بدائع الصنائي

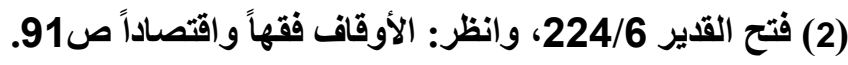

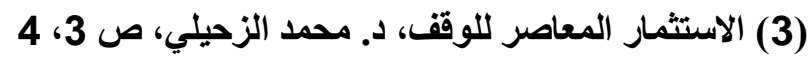
(4) المحاسبة المالية، عبد الباسط رضوان وآخرون، ص صل 542 ـ 54 ـ 
بشكل علمي مدروس، بناء على دراسات فنية متخصصة مختلفة،

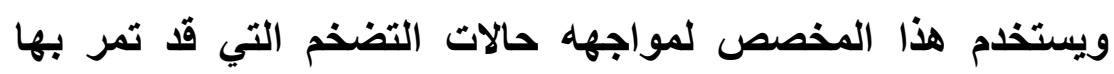
بعض الدول لاعتبارات مختلفة. (1).

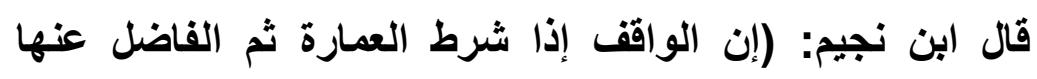

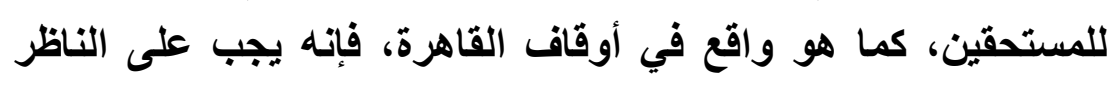

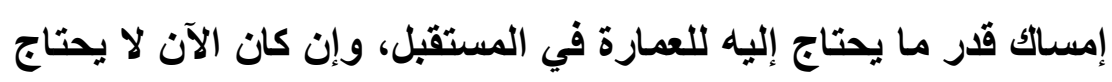

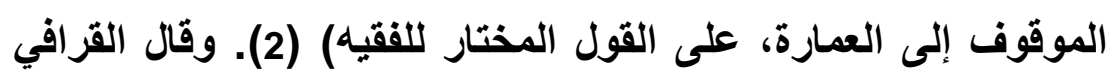

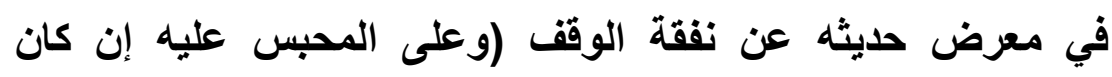

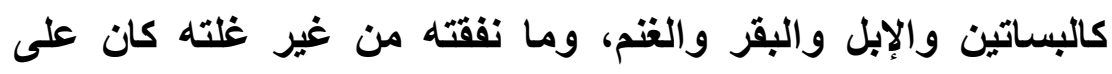

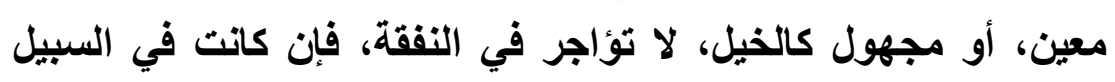

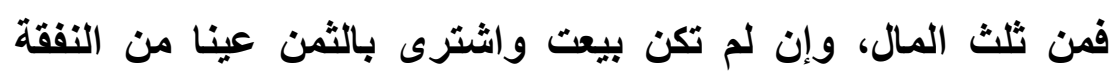

كالسلاح والاروع). (3) المال وان لمن

وقد أثار عدا من الباحثين والفقهاء المعاصرين(4) إلى أهمية

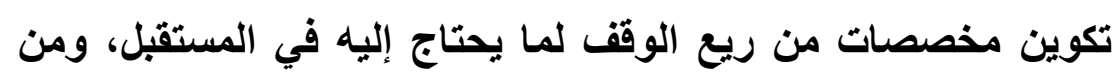

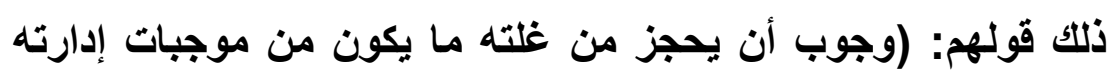

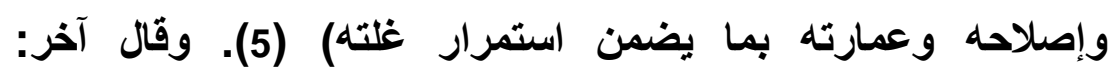

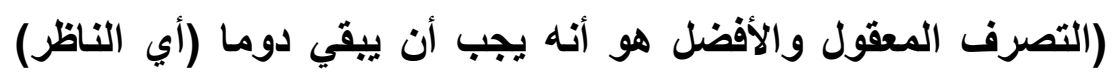

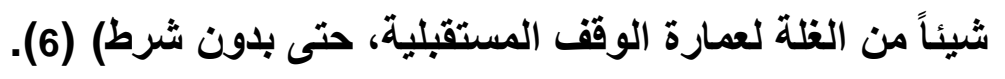

(1) وقف النقود والأوراق المالية وتطبيقاته المعاصرة، عبد العزيز القصار، أعمال

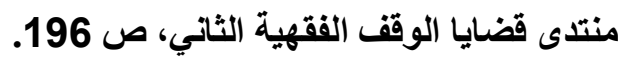

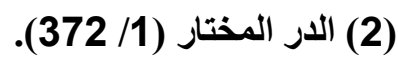
(3) (341/ الذخيرة للقرافي (341) (372).

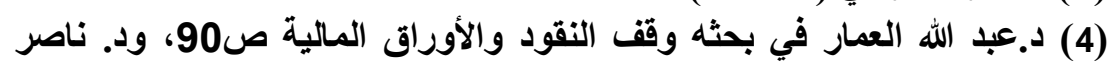

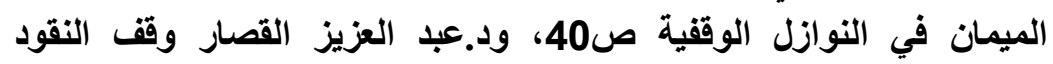

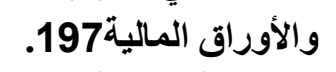

(5) المؤسسة الوققية المعاصرة - مجلة مجمع الفقه الإسلامي العدد 13، 541/1 ع العباللام العبادي. (6) دور المؤسسة المالية الاسلامية بالنهوض بمؤسسة الوقق في العصر الحديث،

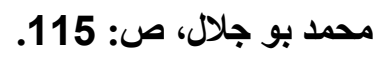


وقد نصت المادة (54) من قانون الوقف المصري على حتمية

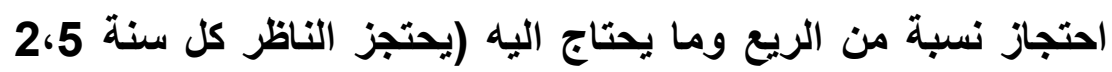

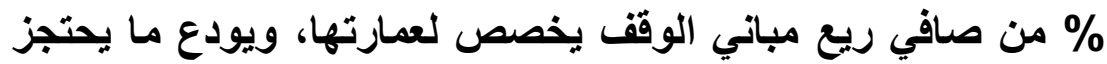

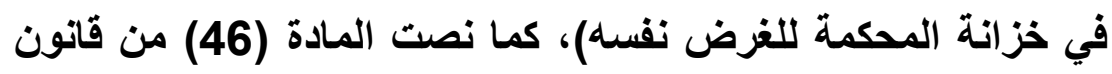

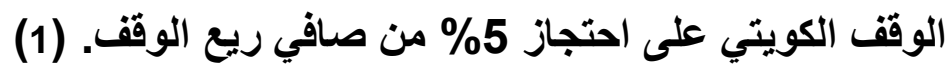

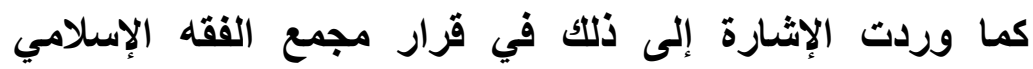

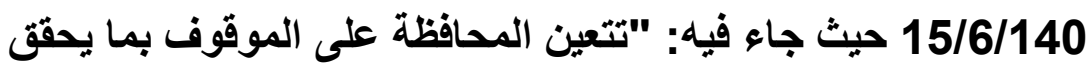
بقاء عينه ودوام نفعه. كما يجوز استثمار الفائض من الريع في تنمية التئية

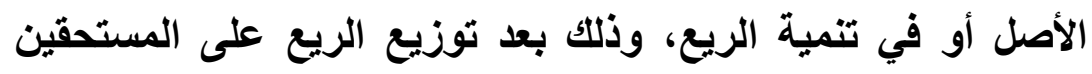

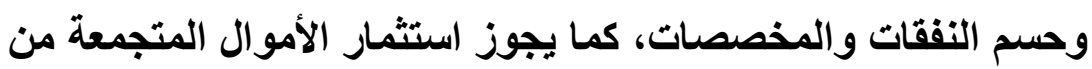
الريع التي تأخر صرفها. كذلك يجوز استثمار المخصصات المتجمعة من الريع للصيانة وإعادة الإعمار ولغير ها من الأغراض المشروعة الأخرى." (2)

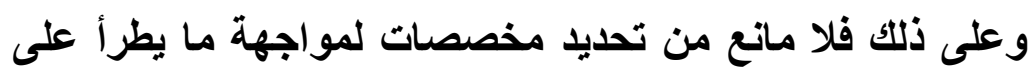

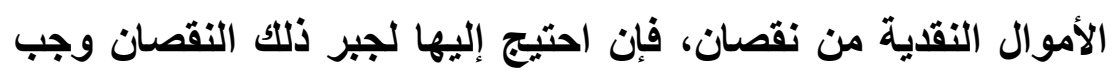

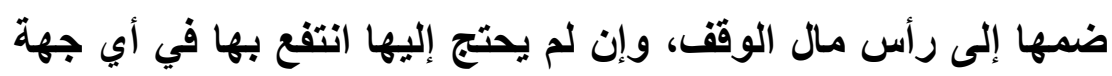

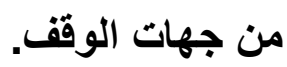
$* * * * *$

(1) القوانين المصرية المختارة، قانون الوقق 2،21، 921- مشروع قانون الوقق

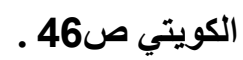

(2) مجلة مجمع الفقه الإسلامي، اللاورة الخامسة عثرة، لمؤتمر مجمع الفقه

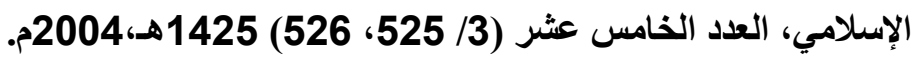




$$
\begin{aligned}
& \text { المبحث الثالث: } \\
& \text { طرق وضوابط استثمار النقود الموقوفة. }
\end{aligned}
$$

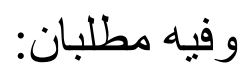

$$
\begin{aligned}
& \text { المطلب الأول: طرق استثمار النقود الموقوفة. } \\
& \text { المطلب الثاني: ضوابط استثمار النقود الموقوفة. }
\end{aligned}
$$




$$
\text { المطلب الأول }
$$

\section{طرق استثمار النقود الموقوفة}

رغم أنّ مسألة وقف النقود كانت مطروحة في الققه الإسلامي منذ قرون عديدة، إلا أنّ ظاهرة وقف النقد لم تكن بهذا الثيوع، ولم يبلغ فئغ ولئ مجال الاستثمار فيها الحال الأي بلغة اليوم؛ بسبب تطوّر مجالات

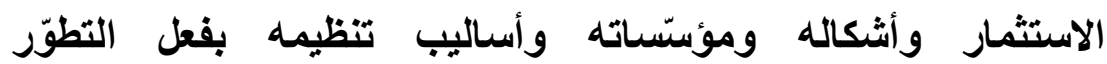
الاقتصادي العام في العالم. لقد كان وقف النقد موجوداً بشكل ضعيف في الأزمنة السالفة. وكان الباحثون في تاريخ الوقف الإسلامي(1) يتحدّثون عن أوقاف نقدية للإقر اض أو الاستثمار والمضاربة بشكل بسيط. وقد نقل البخاري سؤالاًا

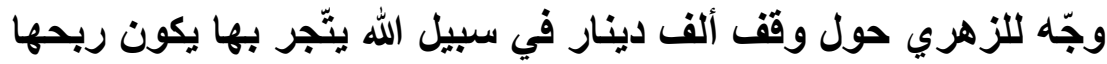
صدقةً للمساكين والأقربين(2). وهو يكثف عن وند تداول الموضوع، ومواققة الزهري عليه، في أوائل القرن الثاني الهجري. كما ورد في

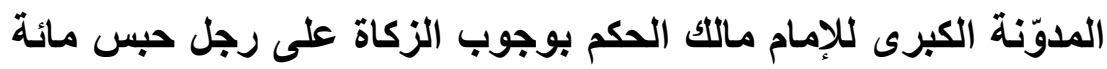
دينار موقوفة يسلقها الناس ويردّونها على ذلك الذي جعلها حبساًأ(3). ومثل ذلك من استفتاءات منقولة عن الإمام أحمد بن حنبل.

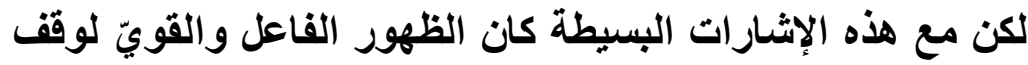
النقود في بدايات العصر العثماني؛ حيث كان في بعض بلاد البلقان، ثم الإن

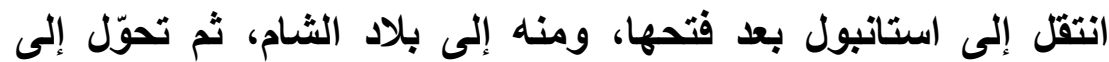

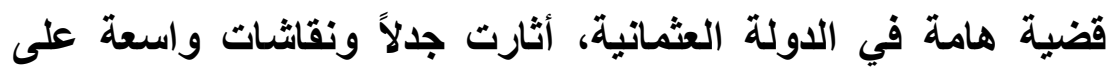

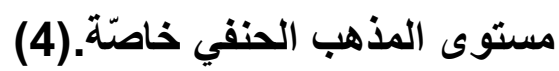

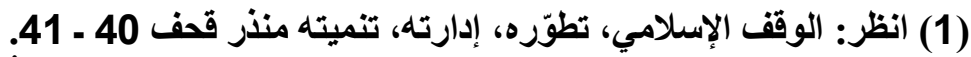

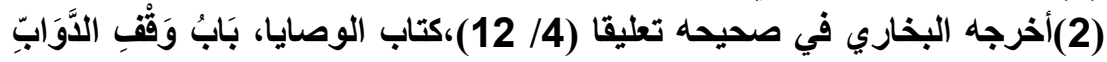

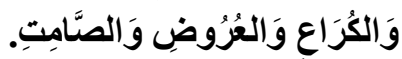

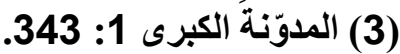

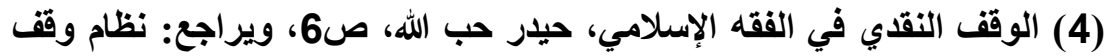

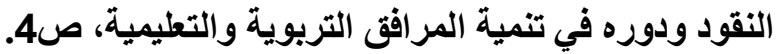


إن الاستثمار يمثل عملية تنمية مستمرة واجتهاد في طلب

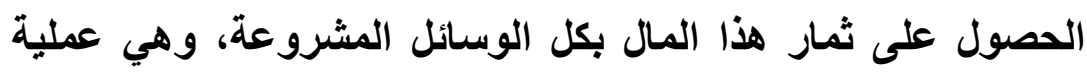

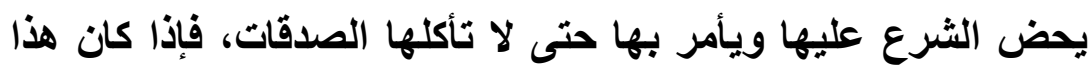

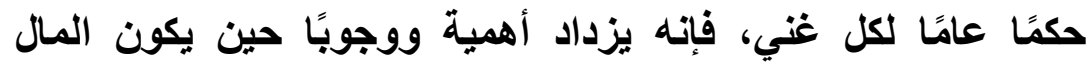

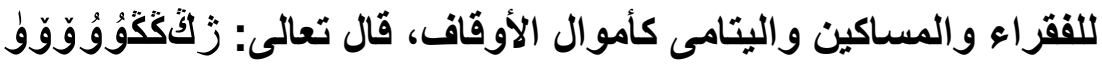

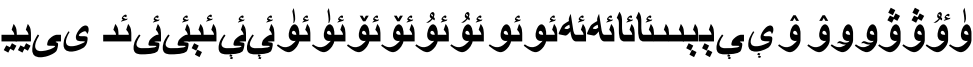
(2) . (1)

قال الخرقي: "وإذا خرب الوقف ولم يرد شيئًا بيع وأشتري بثمنه

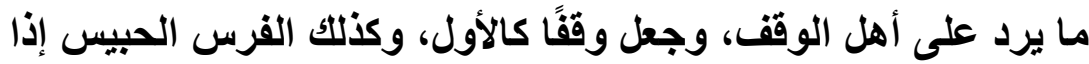

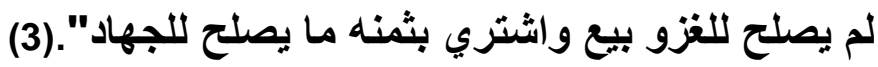

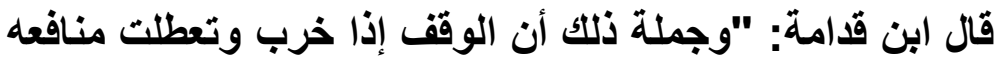
كدار انهامت أو أرض خربت، وعادت مواتا ولم تمكن عمارتها، أو

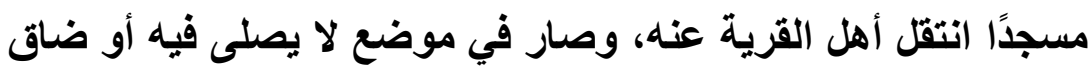
بأهله، ولم يمكن توسيعه في موضعاه، أو تثعب جميعه فلم تمكن

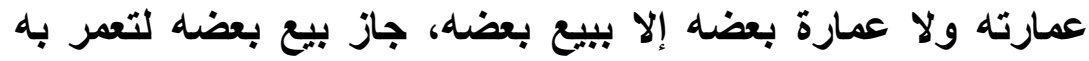

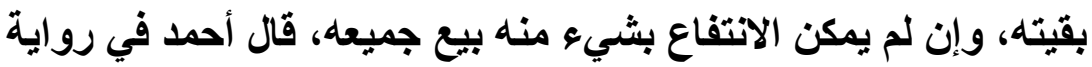

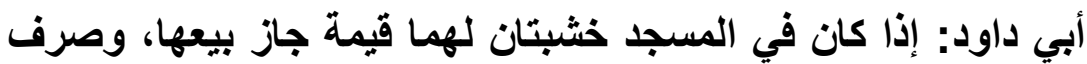
ثمنها عليه". وقال: "أجمعوا على جواز بيع الفرس الحبيس يعني الموقوفة

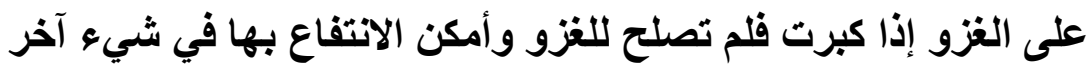
مثل أن تدور في الرحى، أو يحمل عليها تراب، أو تكون الرغبة في

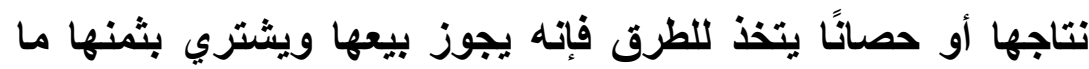
يصلح للغزو، نص عليه أحمد" (4).

(1) سورة النساء، الآيتان: 5، 6. (2) وقف النقود واستثمار ها، د. محمد نبيل غنايم، ص 26 (1)

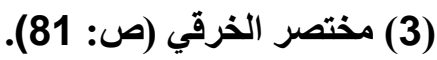

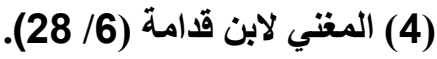


وروي أن عمر ح كتب إلى سعد لما بلغه أنه قد نقب بيت المال الذي بالكوفة أنقل المسجد الذي بالتَّمارين، واجعل بيت المال في قبلة المسجد فإنه لا يزال في المسجد مصل(1)، وكان هذا بمشهر من فئن

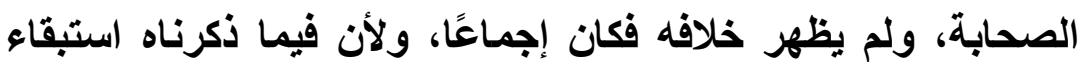
الوقف بمعناه عند تعذر إبقائه بصورته فوجب ذلك .. قال ابن عقيل:

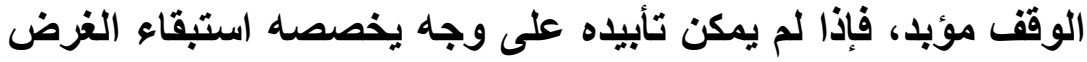
وهو انتفاع على الدوام في عين أخرى وإيصال الإبدال جرى مجري الأعيان، وجمودنا على العين مع تعطلها تضييع للغرض. الغئ.(2)

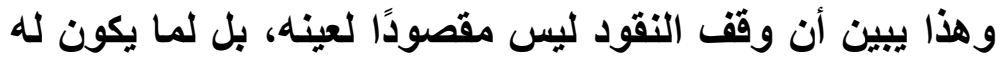
من أثر في نفع الجهة الموقوف عليها، ولا يتحقق هذا النفع إلا بتفعيل

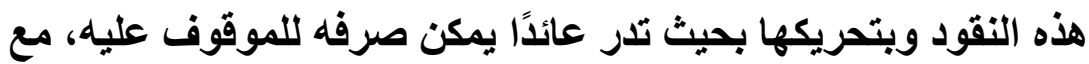

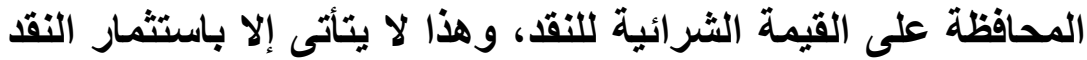
استثمارًا مأمونًا يوفر عائدًا نافمًا. ولما كان استثمار الوقف يحتمل المخاطرة بالمال، كان للبحث الفقهي فيه مجال، نظرًا لخطورة وضع الوقف، لذلك عني مجمع الفقه الإسلامي ببحثّه في دورته الخامسة عشرة وأصدر فيه قرارًا يبين

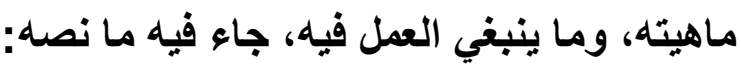
1- يقصد باستثمار أموال الوقف تنمية الأموال الوقفية سواء هاء أكاتت أصولاً أو ريعًا بوسائل استثمارية مباحة شرعًا.

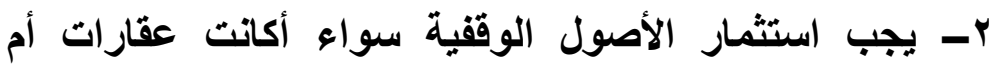
منقولات ما لم تكن موقوفة للانتفاع المباشر بأعيانها.

(1) أخرجه الطبراني في المعجم الكبير للطبراني (9/ 192) حليث (8949)، قال

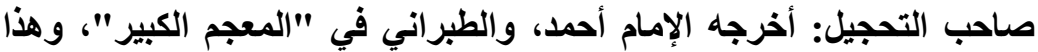

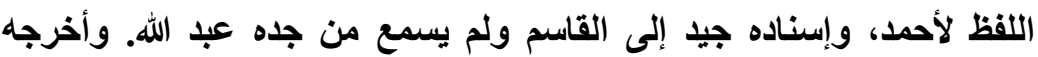

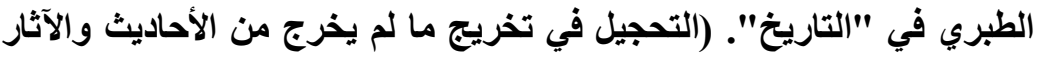
في إرواء الغليل (ص: 252) و إسناده واهِ، لا يصح.

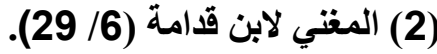


3 - يعمل بشرط الواقف إذا اشترط تنمية أصل الوقف بجزء من

ريعه، ولا يعد ذلك منافيًا لمقتضى الوقف، ويعمل بشرطه كذلك إذا

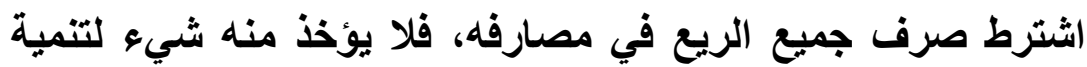

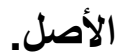

4 - الأصل عدم جواز استثمار جزء من الريع إذا أطلق الواقف

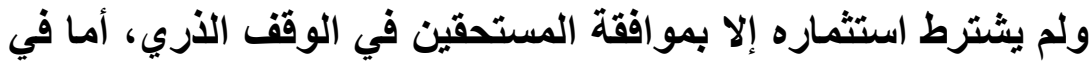
الوقف الخيري فيجوز استثمار جزء من ريعه في تنمية الأصل للمصلحة الراجحة بالضوابط المنصوص عليها لاحقًا.

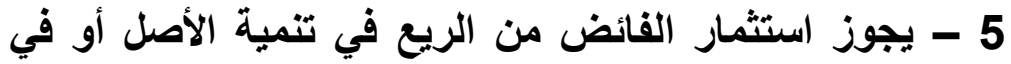
تنمية الريع، وذلك بعد توزيع الريع على المستحقين وحسم النفقات والمخصصات كما يجوز استثمار الأموال المتجمعة من الريع التي تأخر صرفها.

6 - يجوز استثمار المخصصات المتجمعة من الريع للصيانة وإعادة الإعمار ولغيرها من الأغراض المشروعة الأخرى.

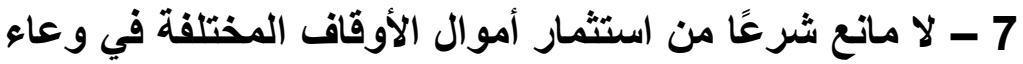
استثماري واحد، بما لا يخالف شرط الواقف، على أن يحافظ على الذمم المستحقة للأوقاف عليها. (1) 
طرق الاستثمار النقدي:

1- عن طريق المضاربة: بدفع هذه النقود أو بعضها على سبيل النئماري

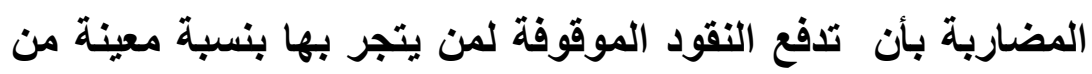

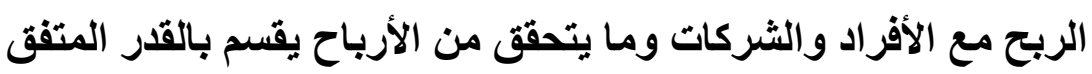

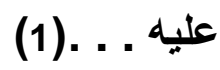

جاء في (المحيط البرهاني) : "وفي (وقف الأنصاري)(2) وكان

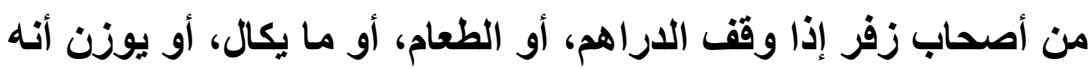

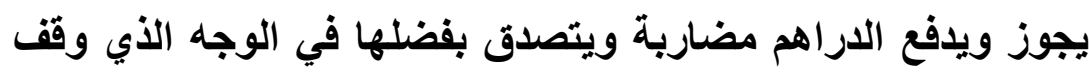

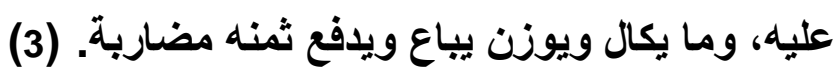

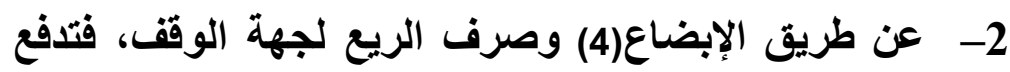

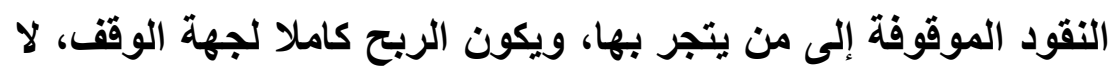

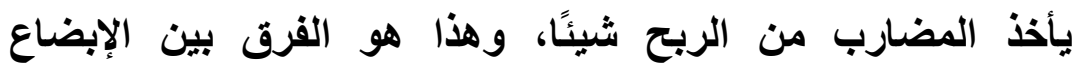

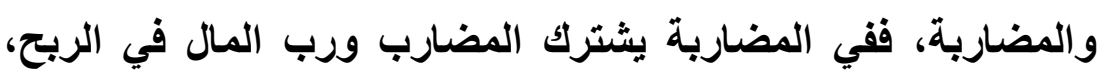

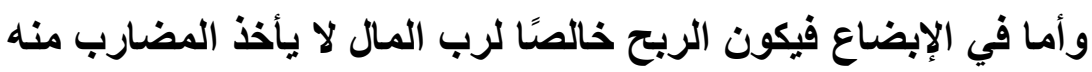

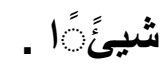

جاء في "حاشية الدر المختار" في شرح قوله في المتن: "ومكيل

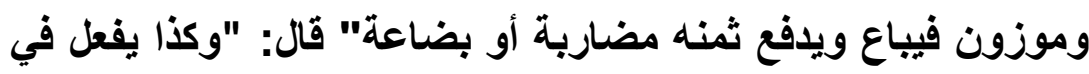
وقف الاراهم والدنانير، وما خرج من ونمنه الربح يتصدق به فيه في جهة

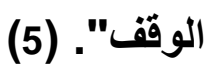

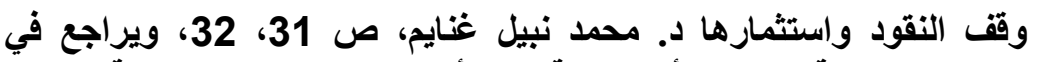

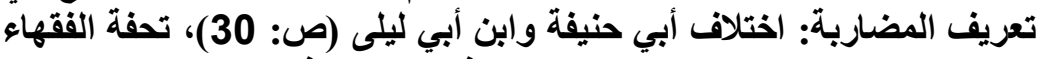

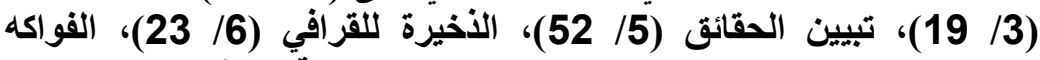

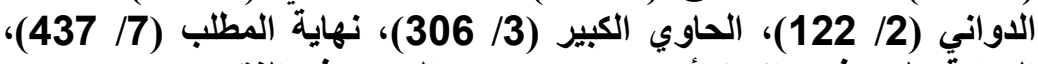

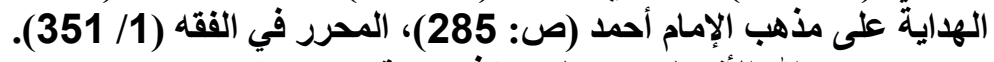

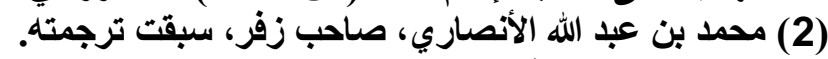

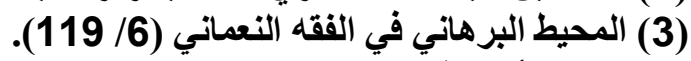

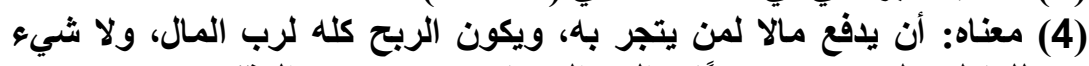

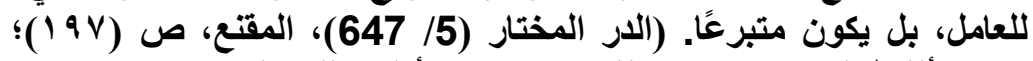

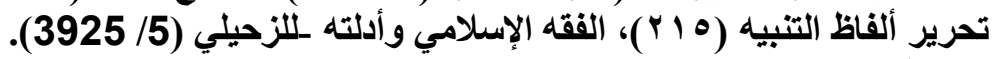

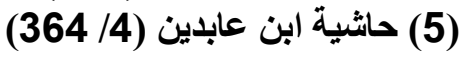


3- عن طريق الإقراض: بمغنى أن النقود تقرض للمحتاجين، ثم

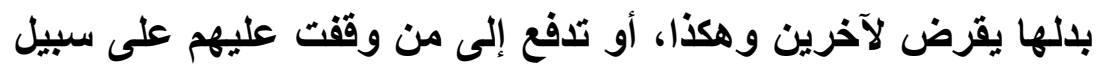

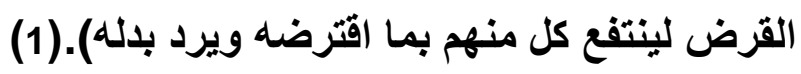

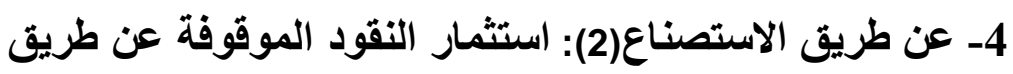

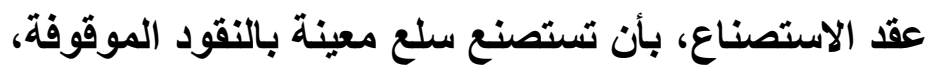

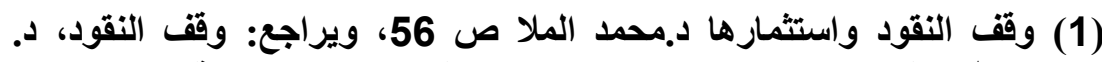
عبدالله الثمالي ص 30 وما بعدها، الاستثمار المعاصر للوقف، د. دمحد

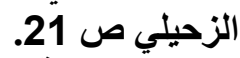

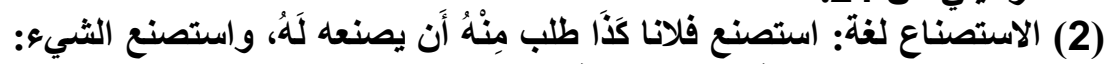

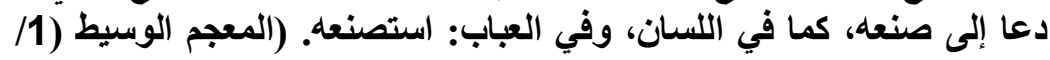

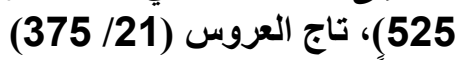

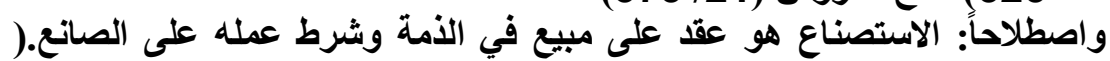

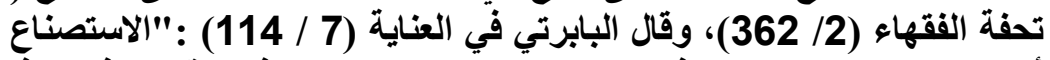

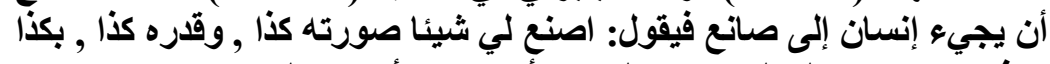

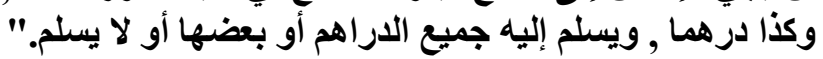

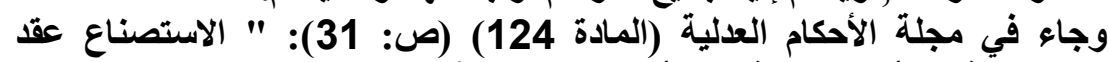
مقاولة مع أهل الصنعة على أن يعطلوا شيئا فالعامل صانع والمشتري مستصنع

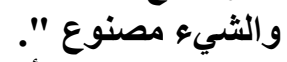

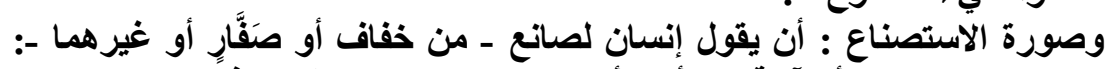

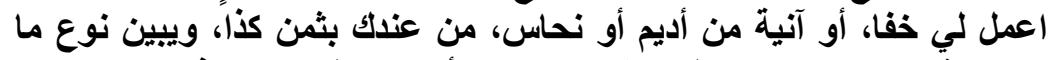

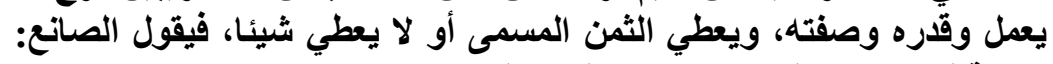

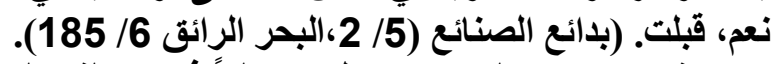

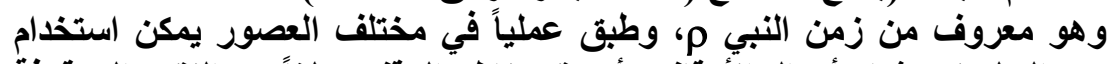

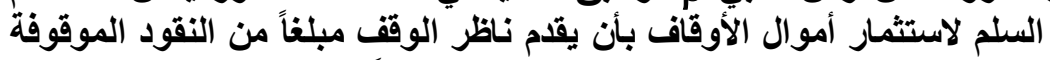

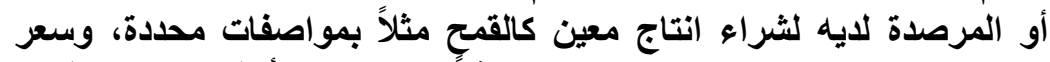

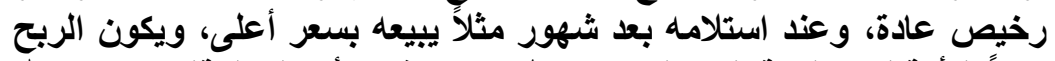

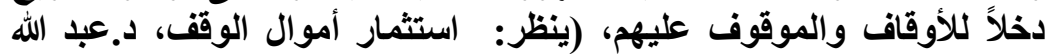
العمار ص108، الاستثمار المعاصر للوقف، د. محمد الزحيلي ص 17). 


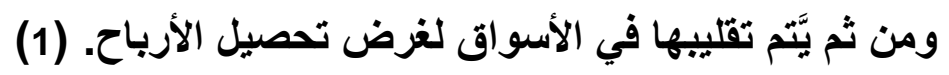

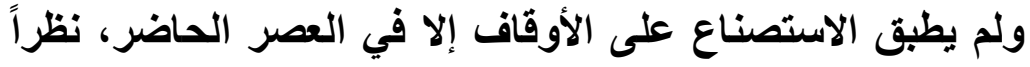
لعدم توفر السيولة النقية عند الأوقاف لتأمين استثمار واستغلال الأراضي الوقفية، ولذلك اتجه المشرفون على الوقف إلى المصارف

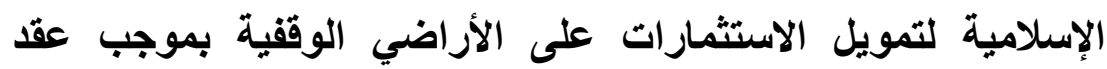

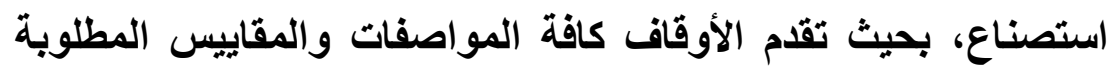

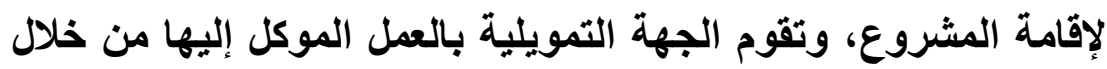

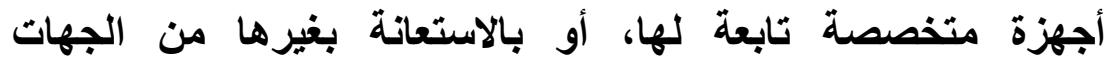
المتخصصة للقيام بهذا العمل. وتقوم الأوقاف باستلام العمل بعد التأكد من مطابتته للمواصفات

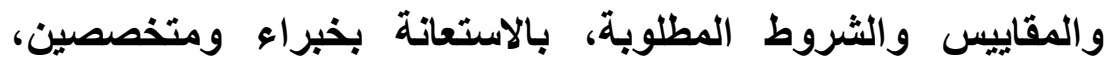

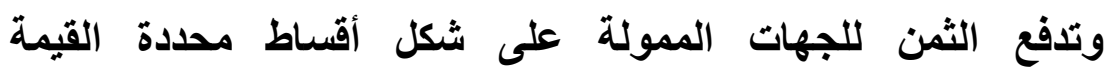
والمواعيد، بناء على الريع المتوقع لاستغلال المشروع، وتوزع قسماً

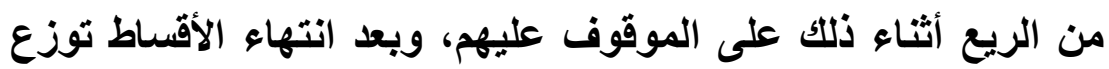
الريع كاملاً عليهم(2).

5 - الاستثمار العقاري: شراء عقارات بالنقود الموقوفة لبيعها كعروض تجارة وتوزيع أرباح البيع على الموقوف عليهم والاحتفاظ

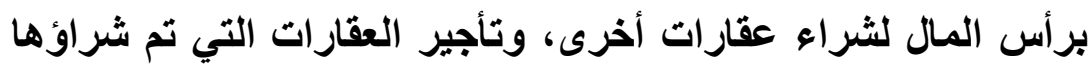

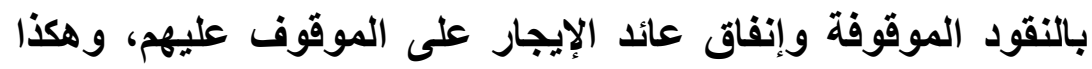
يقى الأصل و هو العقار المستبدل بالنقود وتحصل المنار المنفعة بالإيجار .

(1) وقف النقود واستثمارها د. الملا ص 61، 62، الاستثمار المعاصر للوقف، د.

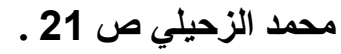

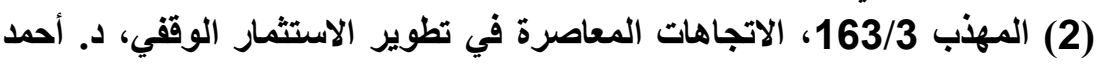

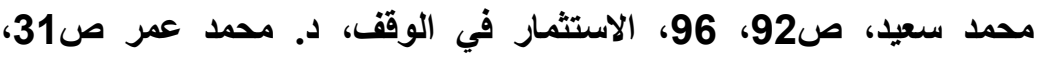

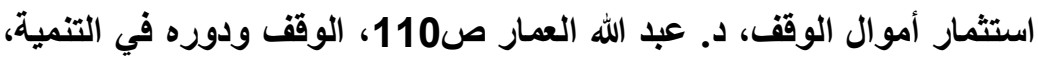

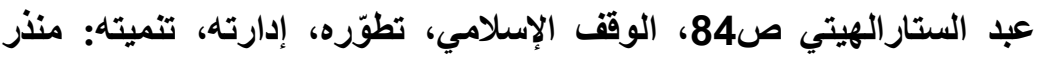


6-عن طريق الشركات الأخرى المشروعة: كشركة العنان عند الجميع، أو الوجوه والأبدان عند بعض الفقهركاء الاجرى، ويلخل الموقوف عليهم بأبدانهم وحرفهم في ذلك مع الآخرين، والدخول بهذه النقود الموقوفة في صفقات الاستيراد والتصدير بنسب من الأرباح لصالح الموقوف عليهم، والمشاركة في شركات التنقيب على المعادن واستثمار الخارج منها وتصنيعه وتوزيع عوائده على الموقوف عليهم، والمشاركة في مشاريع استثمارية قائمة أو تحت الإنشاء، واستغلادل الغلة في الوجه الأي وقفت النقود لأجله . 7 - عن طريق الاستثمار في الأنشطة الزراعية: كتأجير الأرض الأه

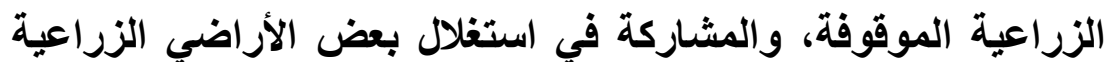
الموقوفة، والمساقاة في استغلال بعض الأراضي المشجرة، والمغارسة في استغلال بعض الأراضي الزراعية الموقوفة.

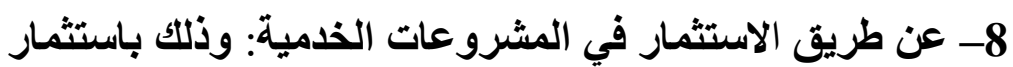
النقود الموقوفة في إنثاء المدارس والمعاهد والجامعات الخاصة استقلالا أو مشاركة. 9 - عن طريق الاستثمار في الأوراق المالية الجائزة شرعاً: كالأسهم العادية لشركات مستقرة، والصكوك الإسلامية الصادرة عن الاون المؤسسات المالية الإسلامية، وسندات المشاركة في الربح والخسارة ذات الطبيعة الآمنة والمستقرة، وصكوتك صناديق الاستثمار الإسلامية، وسندات صناديق الوقف في البلاد الإسلامية، وسندات المقارضة التي تصدرها المؤسسات المالية الإسلامية. وشراء أسهم للشركات التي تتداول أسهمها في البورصة من ذوات النشاط المشروع كشركات

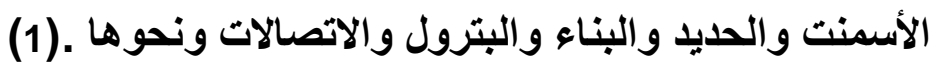


10- عن طريق المساهمة في رؤوس أموال بهدف تحقيق عائد: ولها صيغ كثيرة، مثل المساهمة في رؤوس أموال بعض الشركات، مثل شراء الأسهم، والمساهمة في رؤوس أموال صناديق الاستثمار

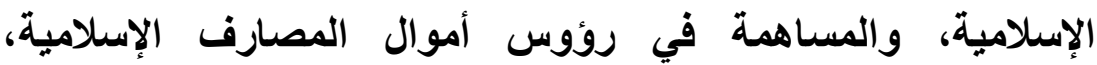
والمساهمة في رؤوس أموال شركات التأمين الإسلامية، والمساهمة وفئة

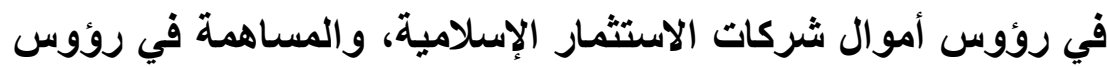

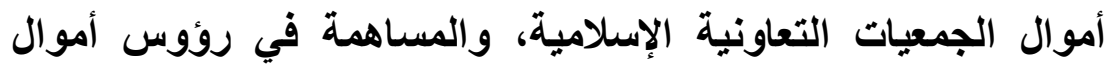

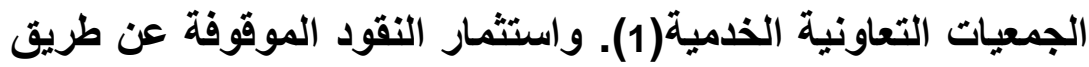
تمويل بعض المشاريع الاقتصادية الناجحة بالاتفاق مع شركاء آخرين

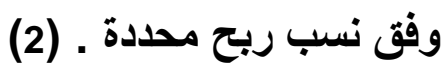
11 - عن طريق المساهمة في الشركات والمصارف الإسلامية

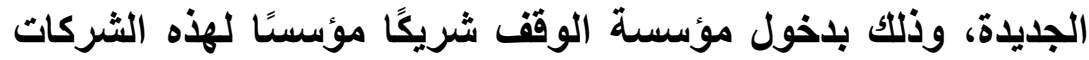

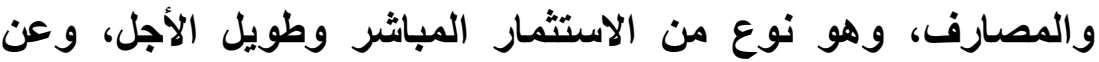
طريق تثكيل أو الاخول في محافظ استثمارية، للاستثمار قصير الأجل في العملات أو الأسهم أو السلع أو نحوها.

(1) إن الاستثمار عامة له خصائص كثيرة، أهمها أن نتيجته مجهولة، فقد يتحقق

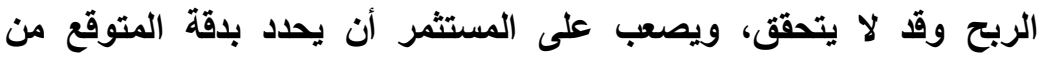
الاستثمار، فهو يعمل في إطار الظن، ويعمل في ظل ولت مخاطر كثيرة لا يمكن

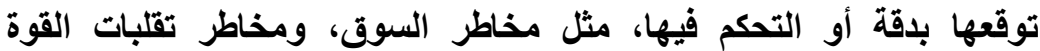

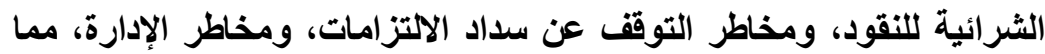

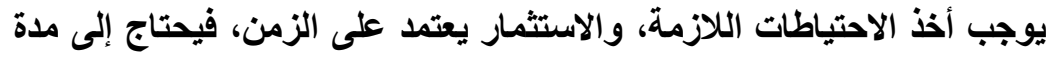

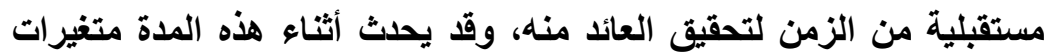

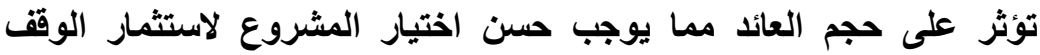

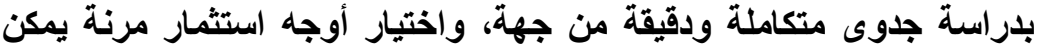

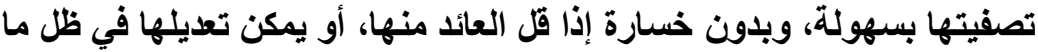

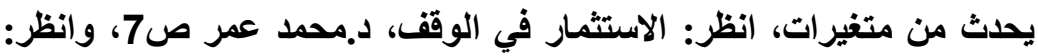

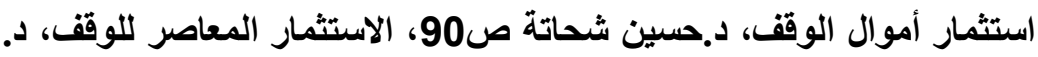

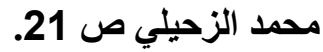
(2) وقف النقود واستثمارها، د. الملا ص 61، 62، 62، الاستثمار المعاصر للوقف، د.

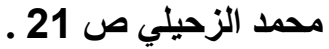


12- عن طريق المساهمة في تأسيس الصناديق الاستثمارية: سواء أكانت طويلة أم متوسطة الأجل. ويتم التنويع في أصول هذا فئه الصناديق، ما بين عقارات، أو معدات، أو مشاريع صناعية أو تجارية التولية

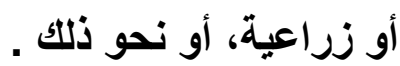

13- عن طريق الاستثمار في المؤسسات المالية الإسلامية من

خلال الحسابات الاستثمارية لأجل: كدفاتر التوفير الاستثماري تحت

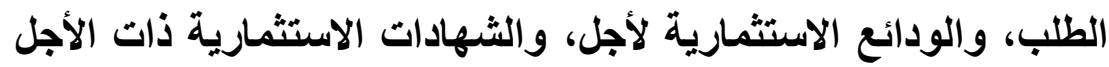

المحدد المطلقة، وذات الأجل المحدد المقيدة. (1)

14- الاستثمار عن طريق سندات المقارضة: وذلك بطرح هذه

السندات على الجمهور ليشتركوا فيها بدفع مبلغ محدد من المال،

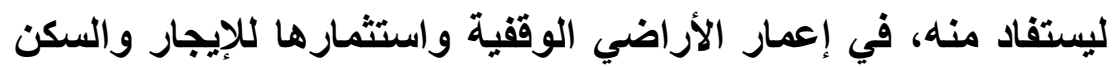

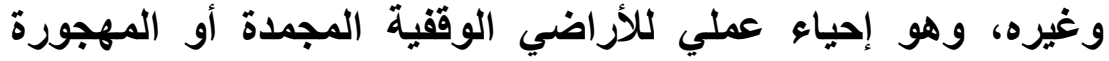

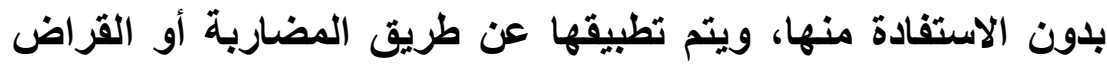
لتحقيق الربح، وتوزيعه على المشاركين والموقوف عليهم.

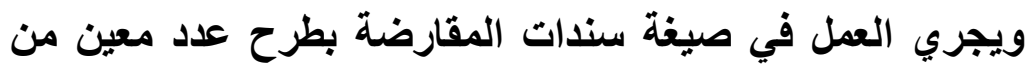

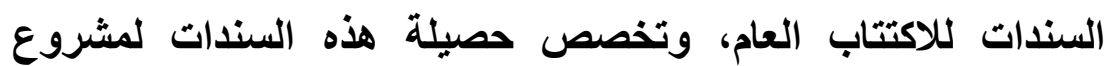

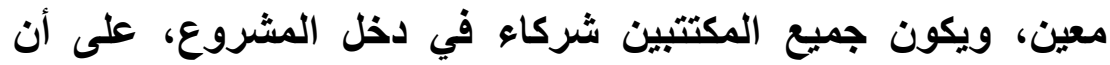

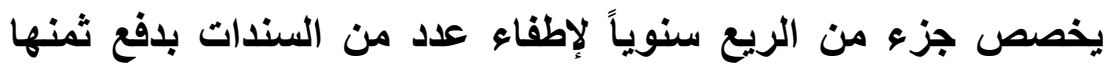

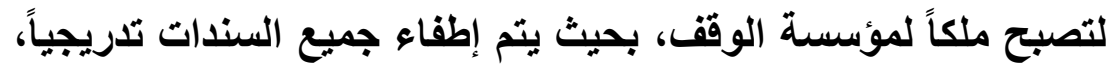

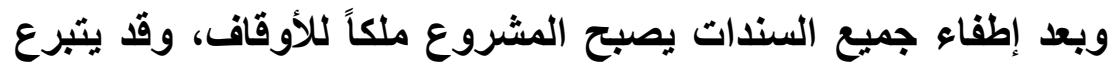
المساهمون أو بعضهم بسنداتهم للوقف، بقصد الأجر والثواب(2).

(1) وقق النقود، د. عبدالله الثمالي، ص 38، الاستثمار المعاصر للوقف، د. محمد الزحيلي ص ص 21.00

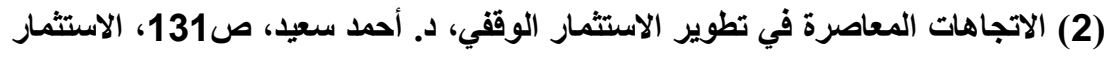

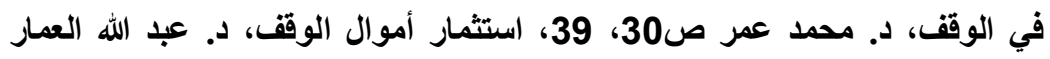

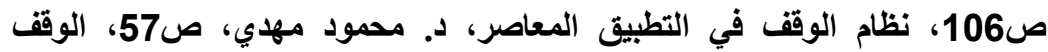
الإسلامي، تطوّره، إدارته، تنميته: منذر قحف صالفئ 271، 275 وما بعدها. 
15- عن طريق المشاركة المتناقصة المنتهية بالتمليك: وهي نوع

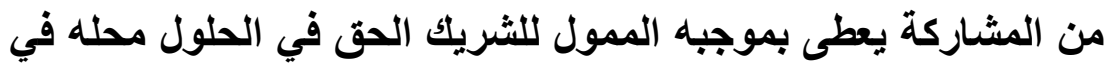
ملكية المشروع، إما دفعة واحدة، أو على دفعات، حسبما تقتضيه الثروط المتفق عليها(1). وهذه الصيغة أقرتها العديد من المؤتمرات الفقهية والندوات العلمية المتخصصة وهيئات الفتوى للبنوك الإسلامية لموافتتها للأحكام الفقهية المقررة في هذا الخصوص(2). وذلك على أساس إجراء ترتيب منظم لتوفير جزء من من الاخل المتحصل ليدفع أقساطاً لسداد قيمة الحصة المتنازل عنها، ليصبح

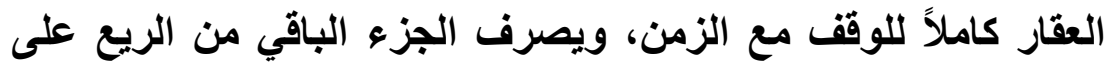

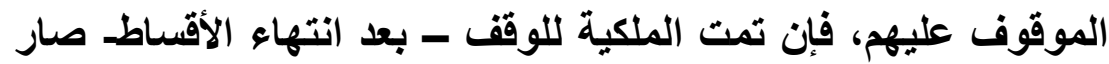

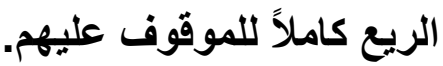
وصورتها أن تقوم شركة تقدم فيها الأوقاف الأرض اللازمة

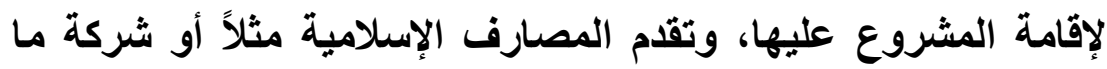

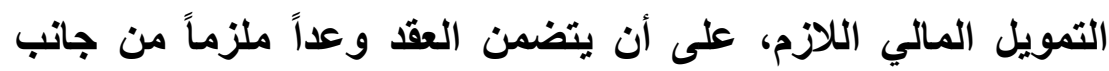

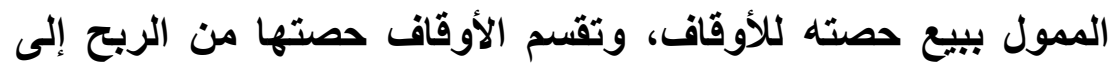

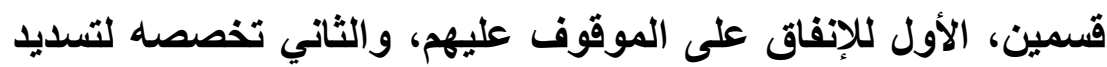

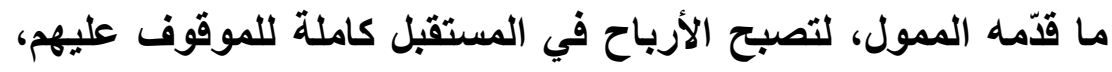
ويثارك المستثمر الممول برأس مال نقدي، وبالإدارة، ويحصل على الماتل

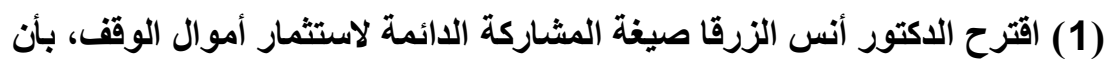

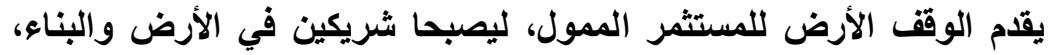

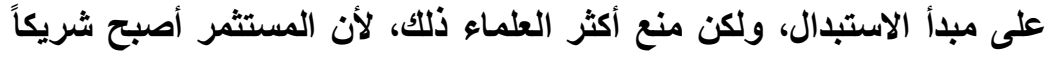
في مال الوقف، وهو لا يجوز (انظر: الاتجاهات المعاصرة في تطوير الاستثمار

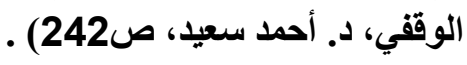

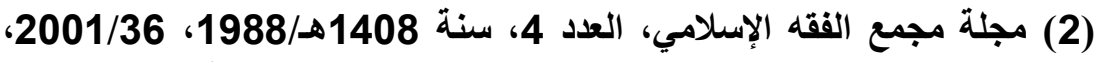

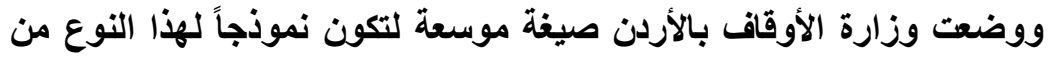
الاستثمار (الاتجاهات المعاصرة في تطوير الاستثمار الوقفي، دون دونة أحمد سعيد، 
عوض عن جهوده الإدارية، ويمكن أن تؤجر الأرض على المشروع

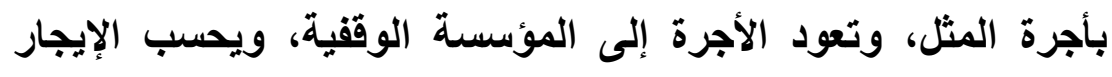

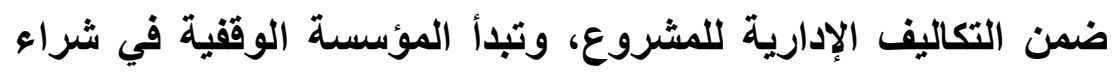
نصيب المستثمر عن طريق الأقساط الميسرة الثهرية أو السنوية، وبناء

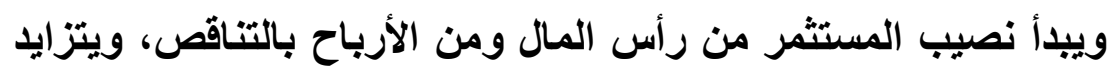

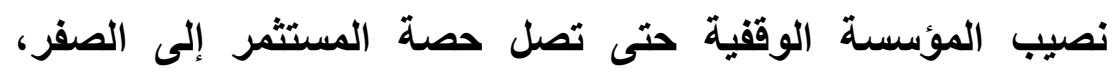

وتستقل المؤسسة الوقفية بالمشروع وتتنهي الملكية الكاملة لهاب(1).

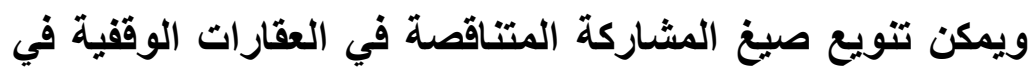

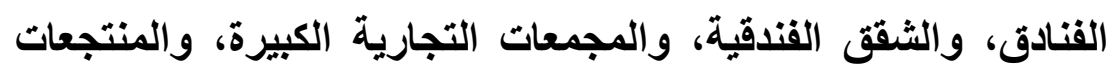
السياحية بشرط الالتزام بالأحكام الثرعية في الحلال والئل والحرام(2).

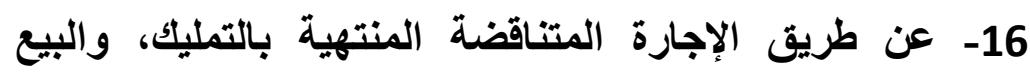

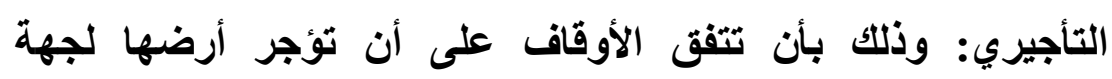

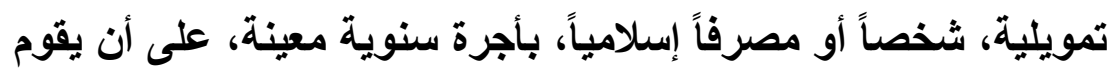

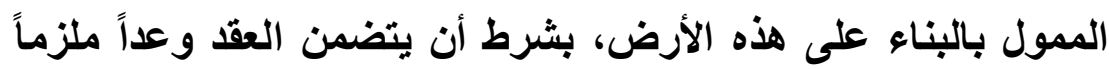

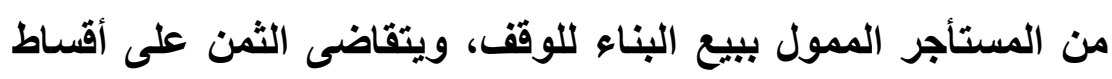

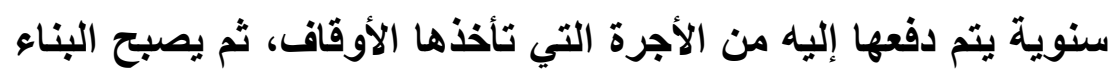

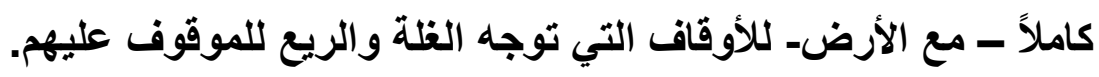

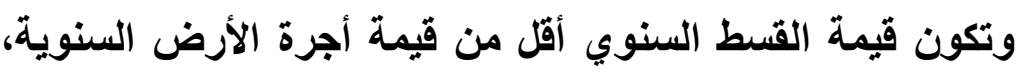

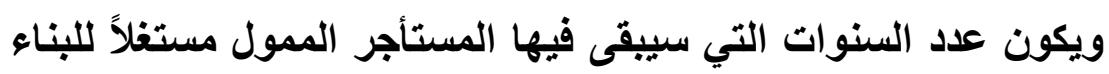

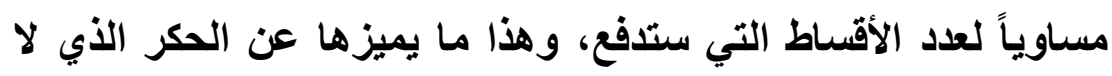

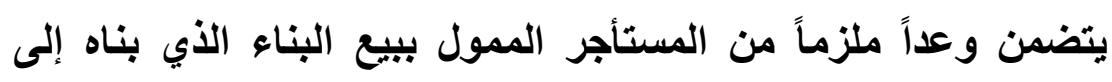

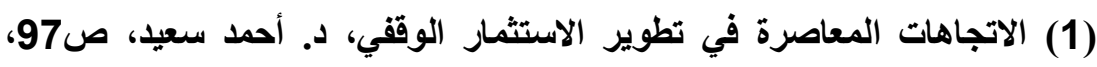

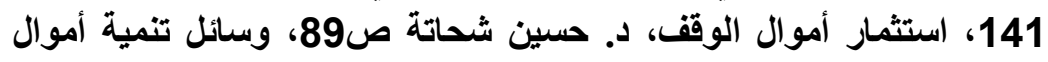

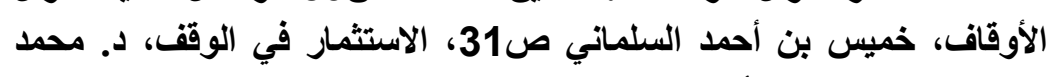

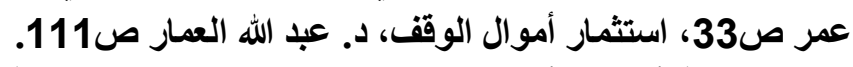

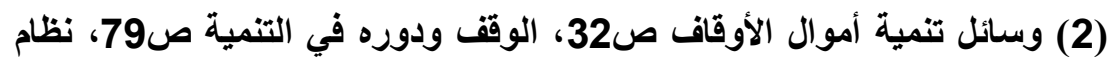

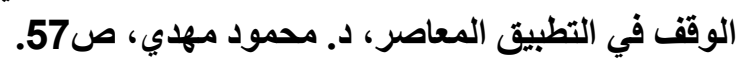


الأوقاف، وإنما يبقى له حق القرار اللائم كما سبق وتم تطبيق ذلك في الأردن وغيره(1).

17- عن طريق التمويل بالمرابحة: وذلك بأن تتفق وزارة الأوقاف

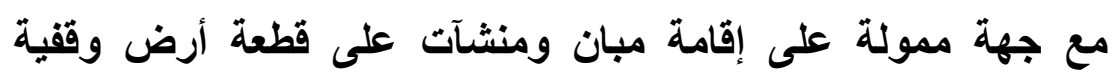

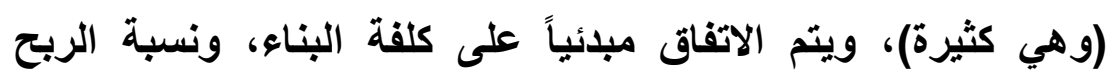

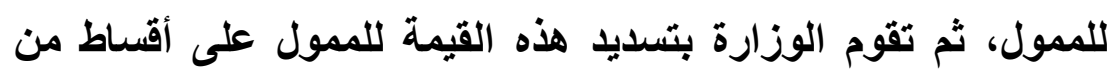

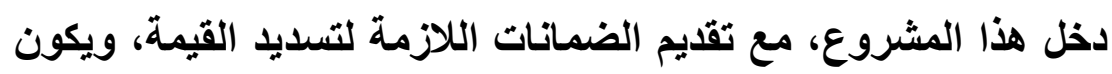

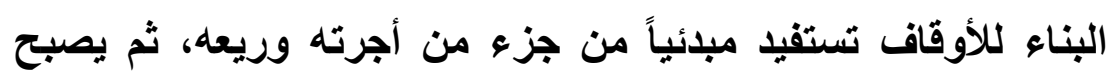

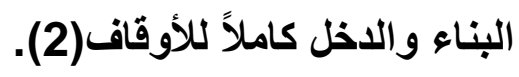
كما يمكن لمؤسسة الأوقاف أن تساهم بالتمويل في الأصول غير فالفاء

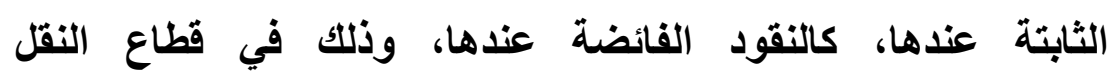

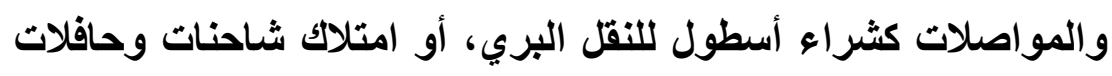

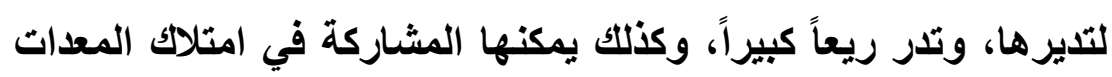

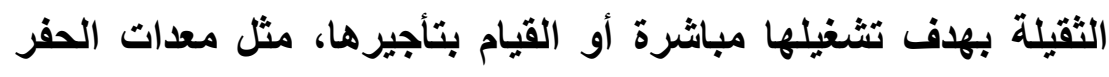
والردم، ومعدات شق الطرق ورصفها، ومعدات حفر آبار المياه وآبار

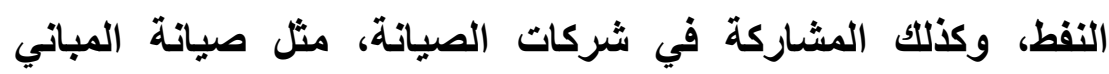

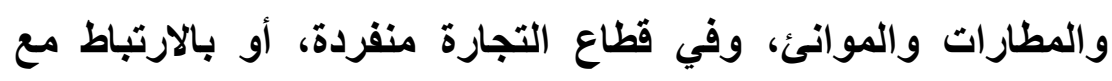

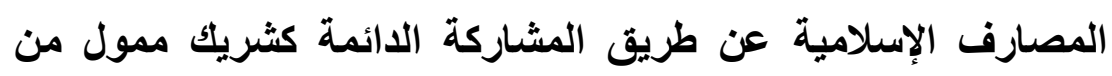

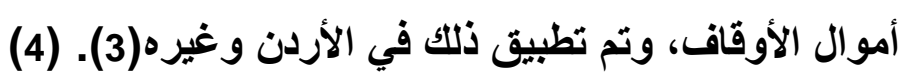

1) الاتجاهات المعاصرة في تطوير الاستثمار الوقفي، د. أحمد محمد سعيد،

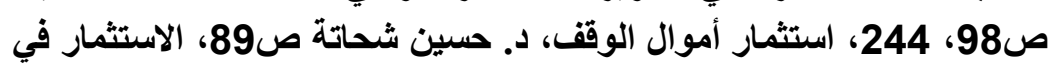

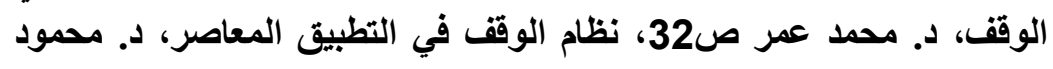

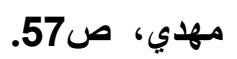

(2) الاتجاهات المعاصرة في تطوير الاستثمار الوقفي، د. أحمد سعيد، ص139.

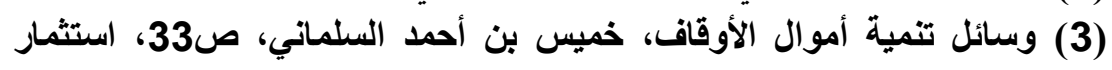

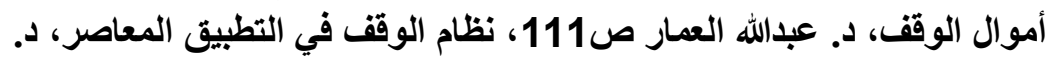

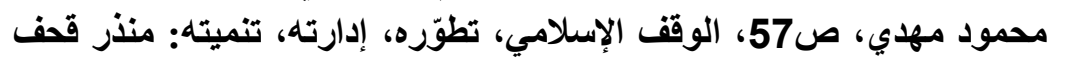


هذا ولا يجوز استثمار النقود الموقوفة في البنوك التي تتعامل بالفو ائد الريوية، وهي المعروفة بالبنوك التجارية عن طريق الإيداع أو الو

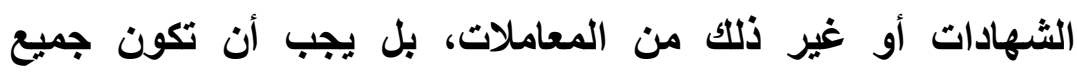
المعاملات السابقة عن طريق المصارف والثركات الثاتية الإسلامية التي

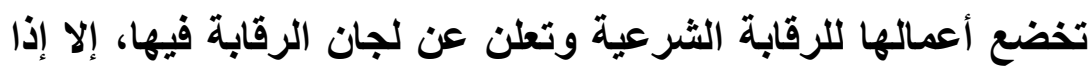

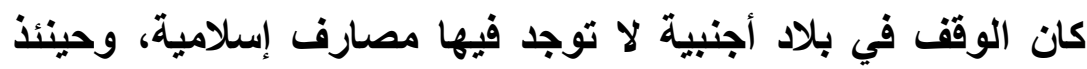
يتخلص من الفوائد في الجمعيات الخيرية . كما أنه لا تحبس النقود كأصل رأسمالي ثابت؛ لأنها سوف تستبلد

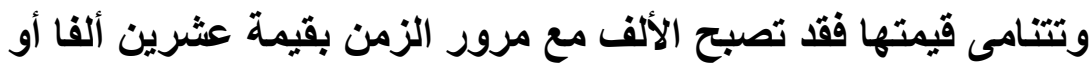

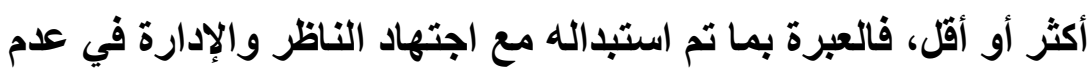

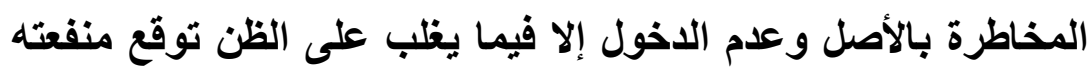

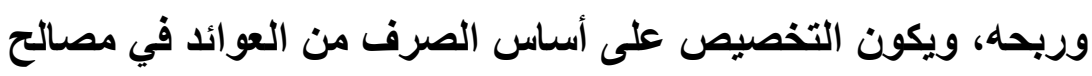

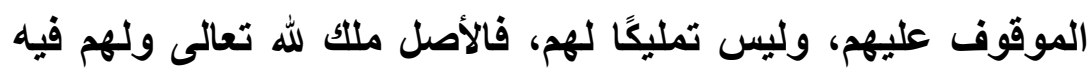

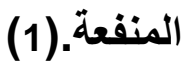

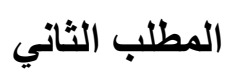

\section{ضوابط استثمار النقود الموقوفة}

هناك العديد من الضوابط التي تحكم عملية استثمار النقود

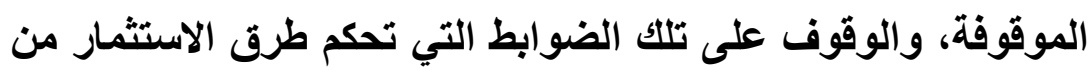

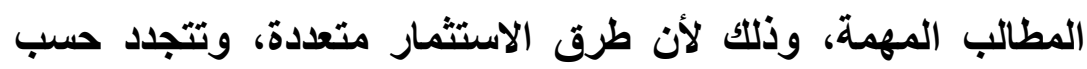
الأزمنة، وتختلف باختلاف الأمكنة.

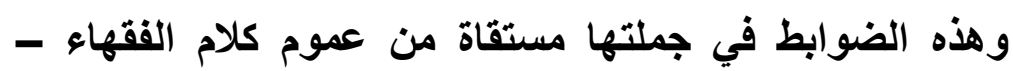

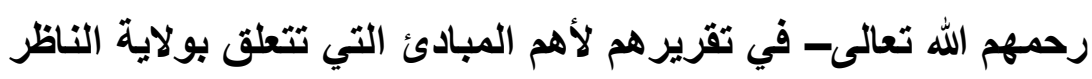

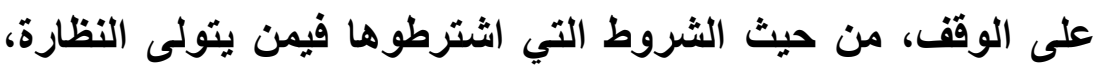

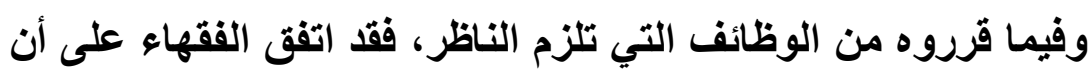


من الثروط التي يجب أن تتوفر في الناظر:(الأمانة، والكفاية)(1)،

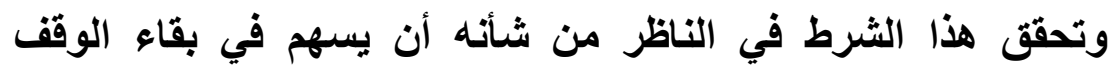

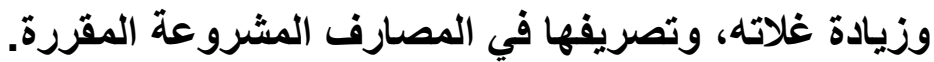

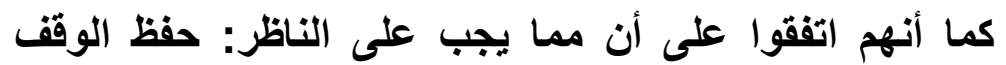
ورعايته، وتحصيل غلاته، والاجتهاد في تنميته، وأن تكون التصرفات التهات

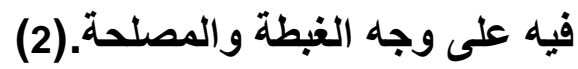
ونصوا على أن الناظر إذا أجر الوقف بأنص من أجناء أجرة المثل؛

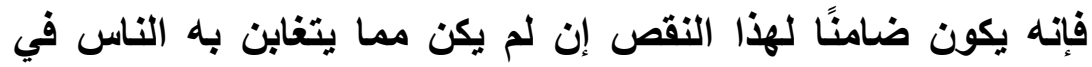

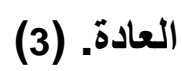
وتتمثل ضوابط الاستثمار النقدي للنقود الموقوفة فيما يلي: الضابط الأول: أن يكون الاستثمار بالطرق المشروعة، فلا يجوز

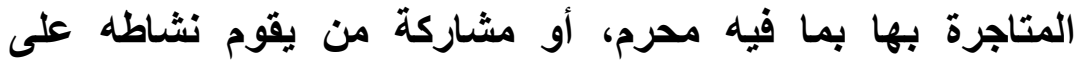

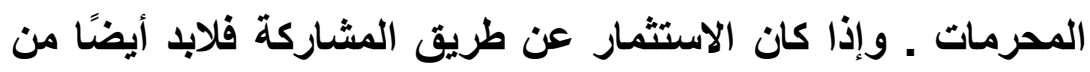

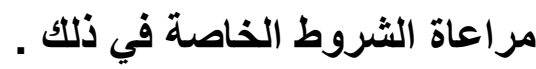
الضابط الثاني: اتخاذ كافة الوسائل المشروعة التي من شأنها

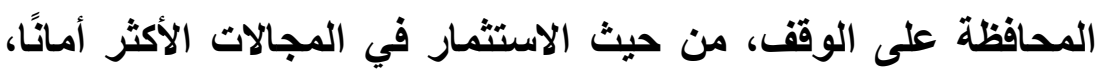
وذلك يختلف حسب اختلاف الأزمنة والأمكنة، وأن يكون الاستثمار

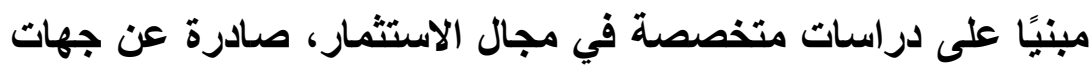

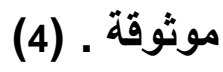

(1) أسنى المطالب (2/ 471)، حاثيتا قليوبي وعميرة (3/ 14 140)، البحر الرائق

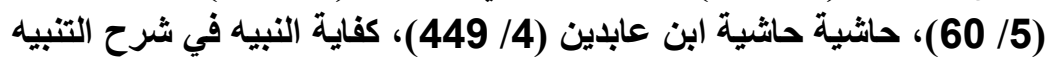

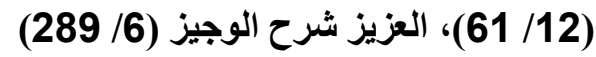
(2) الإنصاف (61/7/67)، الإقناع في فقه الإمام أحمد بن حنبل (15/ 14/2/2)، شرح

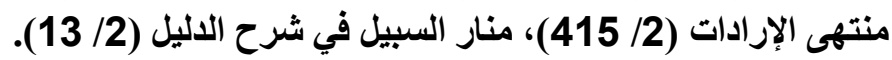

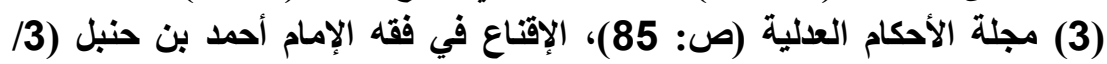

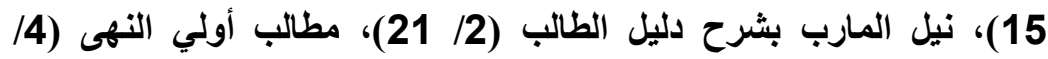

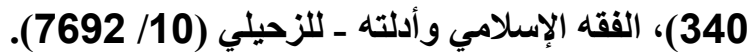
(4) وقق النقود واستثمارها، د. محمد الملا، ص 57، 58. 
الضابط الثالث: الحرص على الالتزام بشرط الواقف وأهدافه من

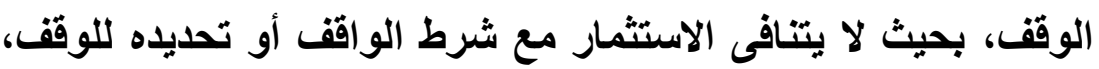

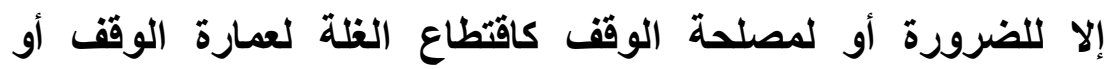
صياتته، أو تغير الأحوال الاقتصادية والاجتماعية بما يعطل الوقف كلياً

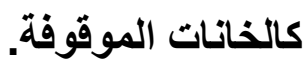

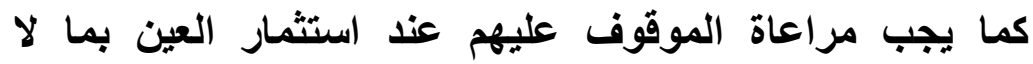
يعرض مصالحهم الخاصة للضياع كالسكن في البناء؛ لأن المنتفع الأول

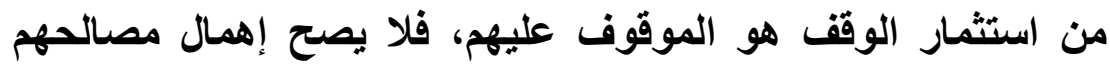
الخاصة ولا العامة. (1) كذلك إذا قيد الاستثمار بطريق فيتقيد به، كما لو قيده بالمضاربة، فلا يعدل عن ذلك إلا إذا تعذر هذا الطريق، كما لو لم يوجد الأمين الذي لئي

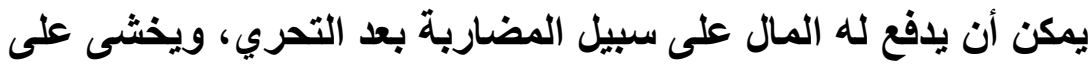

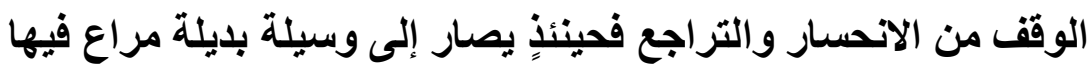

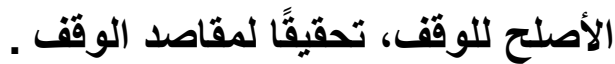
الضابط الرابع: توثيق العقود والاتفاقات والتصرفات التهات التي تتم على التى

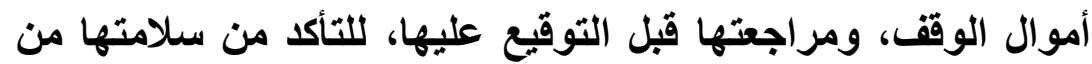

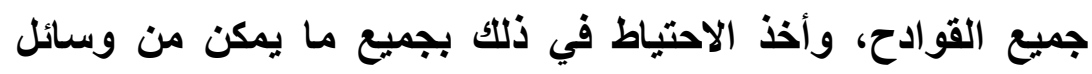

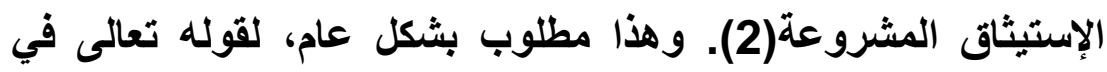

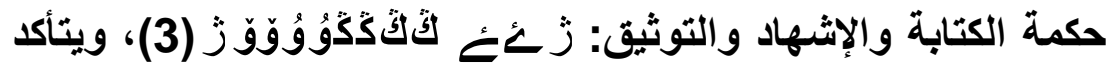

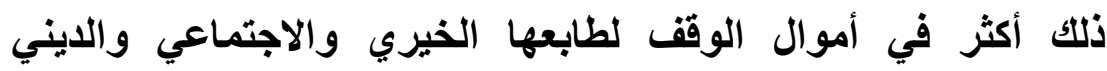
والإنساني، ولطبيتها الزمنية في امتدادها لأجيال وأجيال. (4)

(1) الاستثمار المعاصر للوقف، د. محمد الزحيلي، ص25.

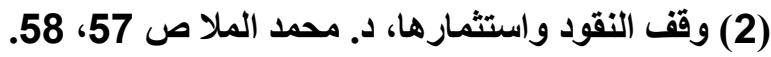
(3) سورة البقرة، من الآية: 282. (4) الاستثمار المعاصر للوقف ـــــ محمد الزحيلي، ص252. 
الضابط الخامس: دراسة جدوى الاستثمارات المختارة. وهذا

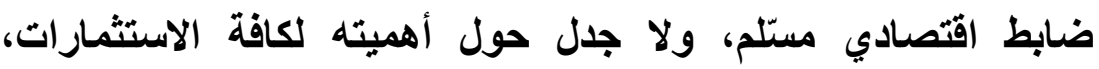

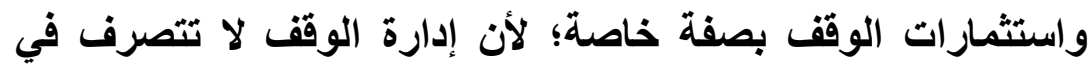

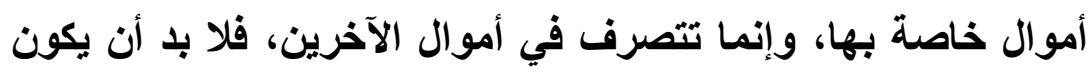

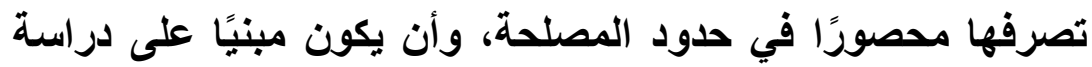
لكافة جوانب المشروع، بناء على التحليلات الاقتصادية والمالية

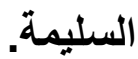

الضابط السادس: الموازنة بين المنفعة الاقتصادية والمنفعة

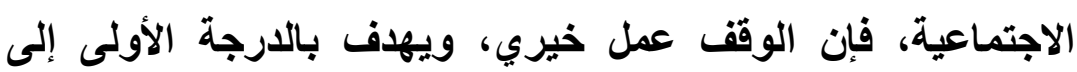

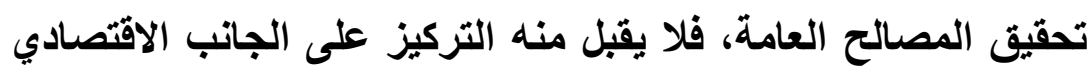
المادي، وإهمال الجوانب الاجتماعية الأخرى .

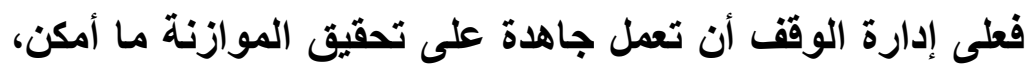

وذلك بالبحث عن المشروعات التي يمكن بواسطتها تحقيق أفضل التصن

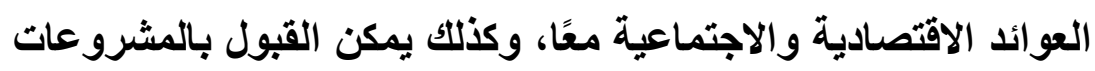

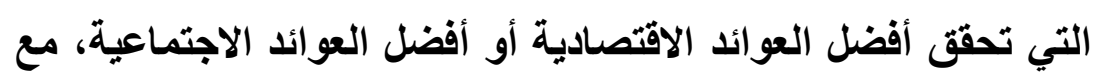
ضرر يسير ومقبول وغير مؤثر بالجاتب الآخر .

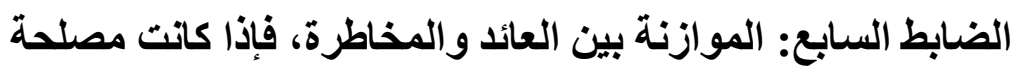

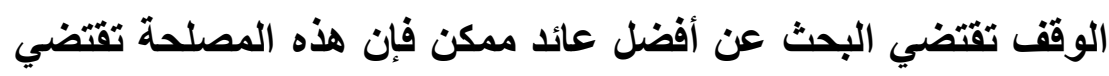

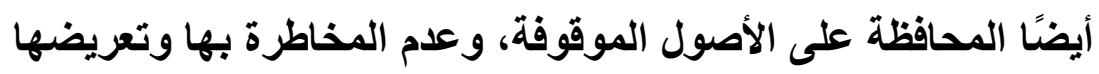

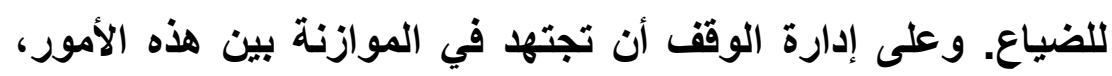

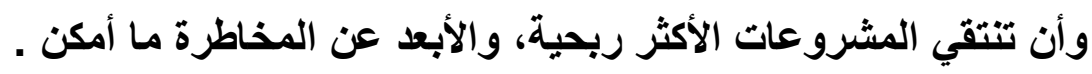

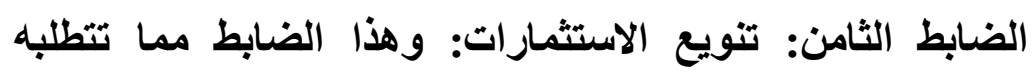

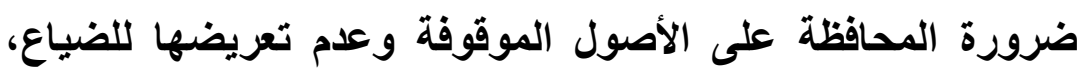
وهو مما يقتضيه الاستثمار السليم للحصول على أفضل العوائد، وهذا لهنا

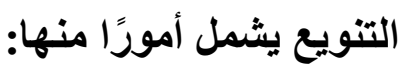




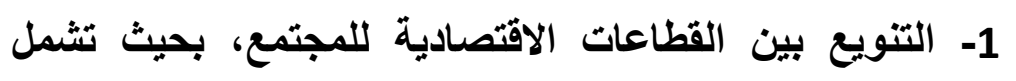

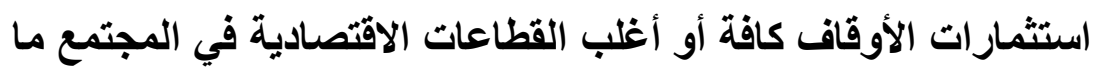

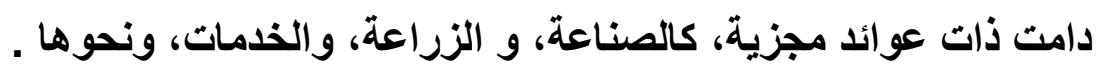

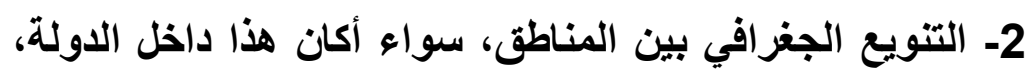

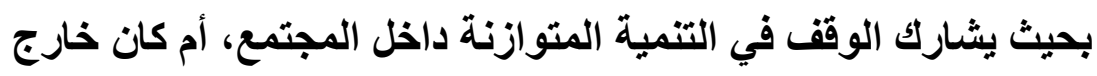

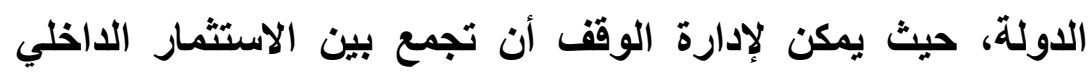

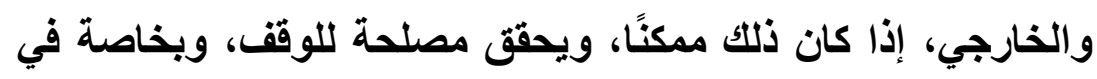

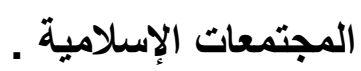

3- التتويع بين مدد الاستثمارات، بحيث يكون بعضها استثمارًا

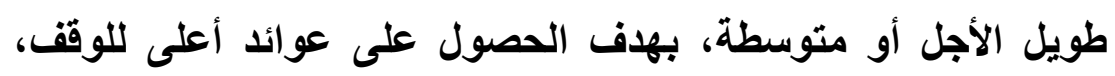

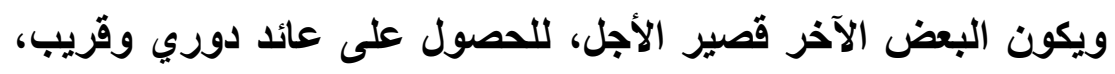

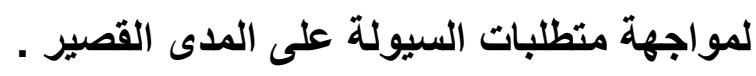

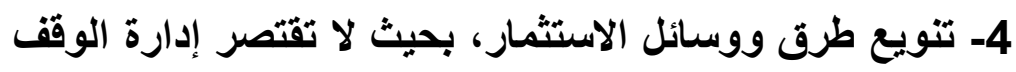

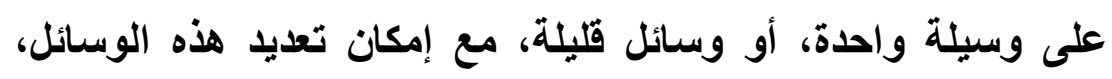

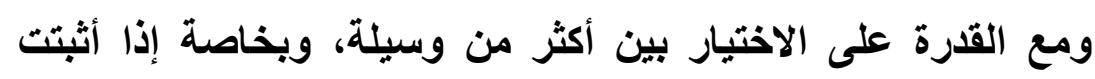

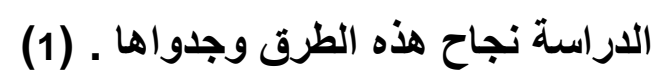
الضابط التاسع: اختيار مجال الاستثمار الذي يؤمن الربح الأليح الأفضل،

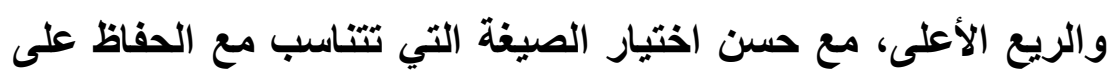

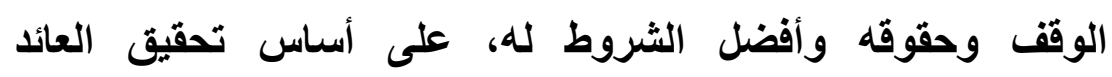

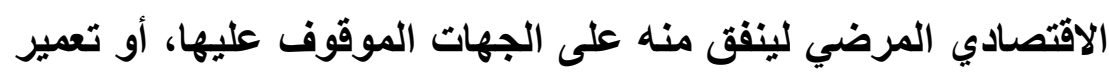

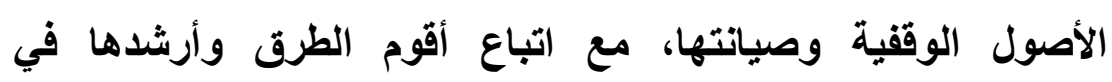

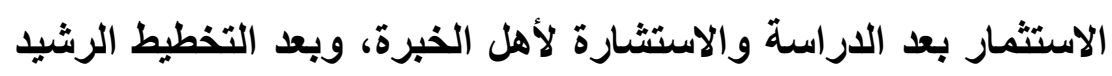

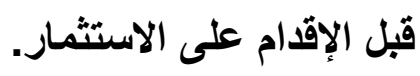


الضابط العاثر: استبدال صيغة الاستثمار ومجاله حسب مصلحة الوقف، وبعد دراسة الجدوى لكل مشروع يساهم فيه الوقف؛ لأن

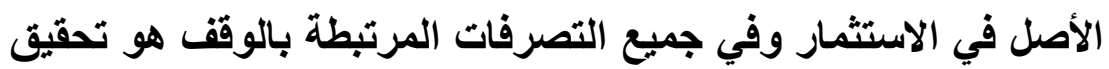

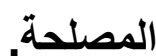

الضابط الحادي عشر: استثمار أموال الوقف في المشروعات

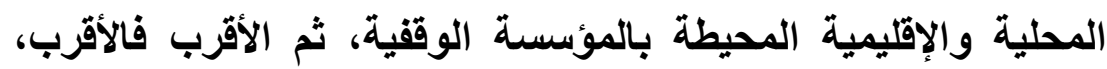
وتجنب توجيهها إلى الدول الأجنبية، أو خارج البلاد الإسلامية. الضابط الثاني عشر: ضرورة المتابعة الدائمة، والمراقبة الاقيقة، الأبها وتقويم الأداء المستمر للتصرفات والحركات التي تتم على أموال الأوقاف واستثمار اتها، للتأكد من حسن سيرها وفقاً للخطط المرسومة، التهاء

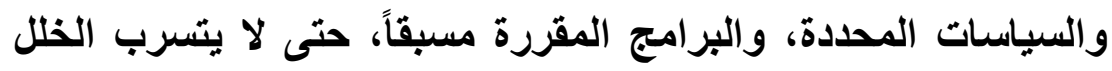

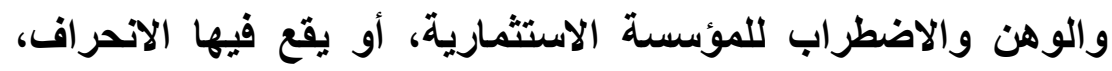

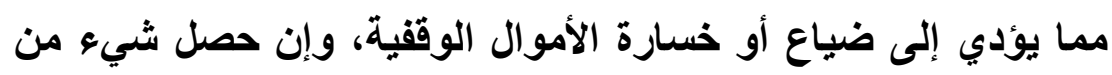
ذللك تمّ علاجه أولاً بأول حتى لا يتفاقم أو يتضاعف.

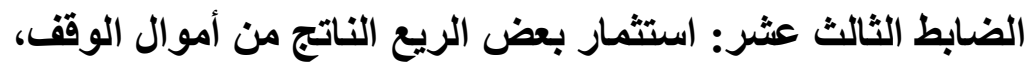

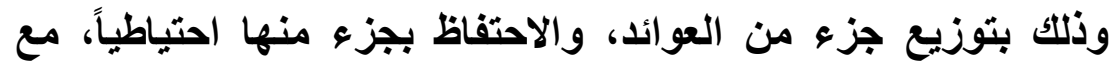

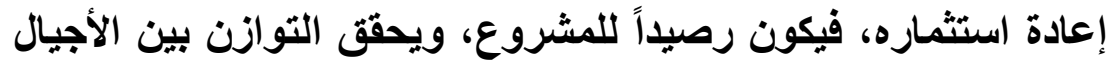

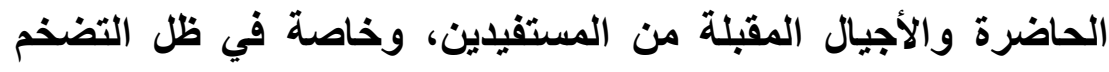
وانخفاض القيمة الاقتصادية لأموال الوقف، ولتجديد الأصول الوقفية ولئية

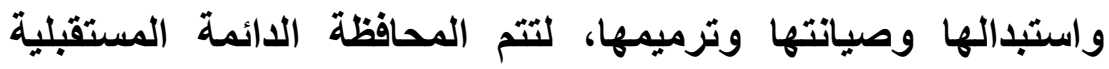

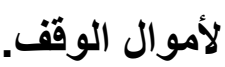
الضابط الرابع عشر: تحقيق الهلف من الوقف الذي حدده الواقف،

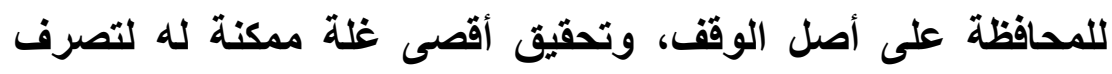
على الجهات المحدة للموقوف عليهز. 
الضابط الخامس عشر: مراعاة العرف التجاري والاستثماري، لأن

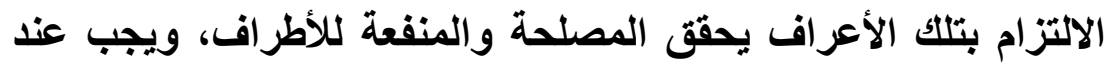
استثمار أموال الوقف تحقيق المصلحة للوقف.

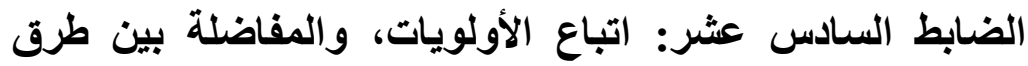
الاستثمار ومجالاتها، وهذا خاضع للتطور، ومعرفة الأحوال الاقتصادية و الاجتماعية في مكان الاستثمار. الضابط السابع عشر: الحرص على تقليل المخاطر الاستثمارية،

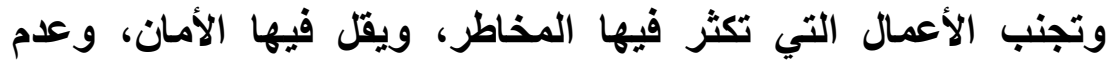
تعريض الأموال الوقفية لدرجة عالية من المخاطر، مع تأمين الحصول

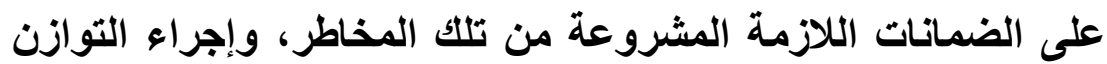
بين العو ائد والأمان، وتجنب اكتناز أموال الوقف. (1)

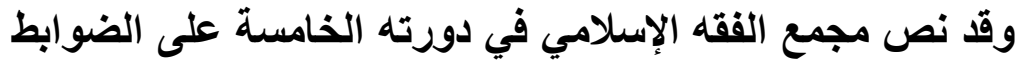

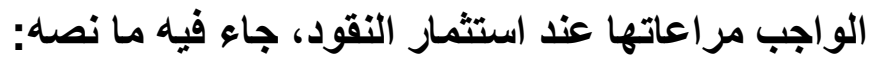
يجب عند استثمار أموال الوقف مراعاة الضوابط الآتية: أ- أن تكون صيغ الاستثمار مشروعة وفي مجال مشروع.

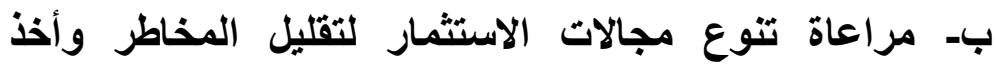

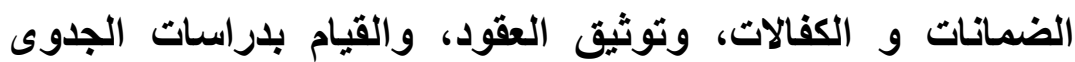
الاقتصادية اللازمة للمشروعات الاستثمارية.

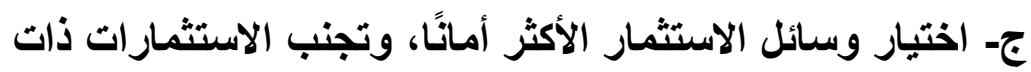
المخاطر العالية بما يقتضيه العرف التجاري والاستثماري.

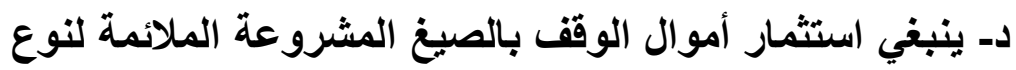

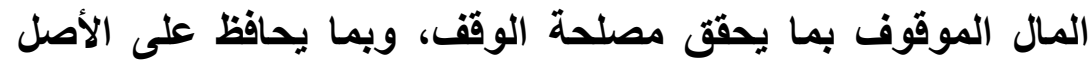
الموقوف ومصالح الموقوف عليهم. وعلى هذا، فإذا كانت الأصول الأليال الموقوفة أعيانًا، فإن استثمارها يكون بما لا يؤدي إلى زوال ملكيتها، 
وإن كانت نقودًا فيمكن أن تستثمر بجميع وسائل الاستثمار المشروعة

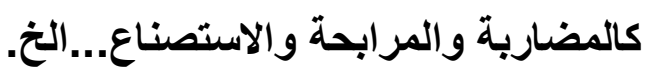

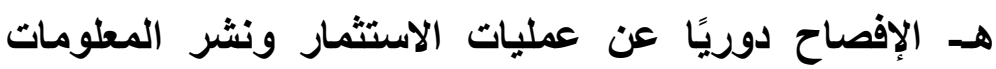
و الإعلان عنها حسب الأعراف الجارية في هذا الثأن.

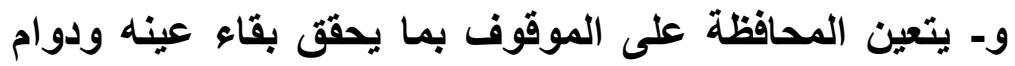
de:i وعند مراعاة هذه الضوابط الشرعية والخبراتية يتعين الاستثمار الأمثل للوقف مما يحقق الفائدة المرجوة(1). (2) $* * * * *$

(1) مجلة مجمع الفقه الإسلامي، الدورة الخامسة عشرة، لمؤتمر مجمع الفقه الإسلامي، (1) (526،527/3) . (2) وقف النقود واستثمارها، د. أحمد الداد،، ص413، 42. 


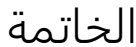

الحمد لله الذي بنعته تتم الصالحات، والصلاة والسلام على سيدنا محمد المبعوث بالرحمات، وعلى آله وصحبه ومن تبعهم بإحسان إلى لى لئل

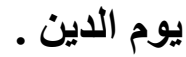

وبعد، فقد كثفت هذه الاراسة عن العديد من النتائج التي كان

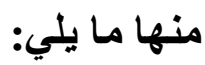
1- أرجح تعاريف الوقف هو تعريف ابن قدامة للوقف بأنه: "تحبيس الأصل وتسبيل المنفعة".

2- المراد بالنقود عند الفقهاء: الذهب والعبلهي والفضة، والعملة المتخذة

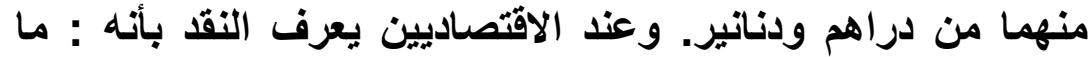
استخدمه الناس مقياساً للقيم، ووسيطاً في التبادل وأداة للادخار.

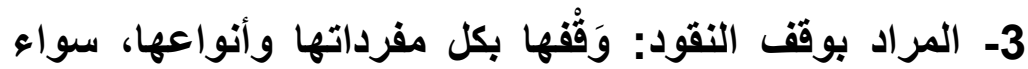
أكان الموقوف ذهباً أو فضة أو شيئاً فيه شيء منهما، أو كان أن عملة فئة معدنية، أو ورقية، مما عد ثمناً للأشياء وقيماً للسلع، ووسيلة فئة فئل للتبادل.

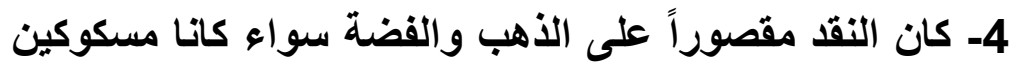

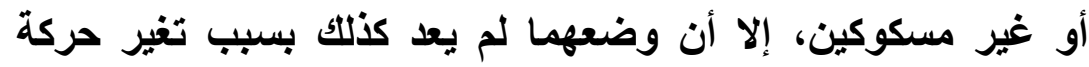

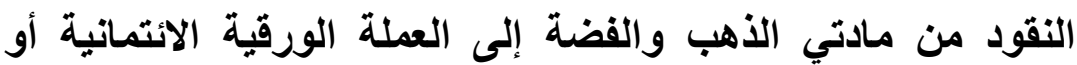

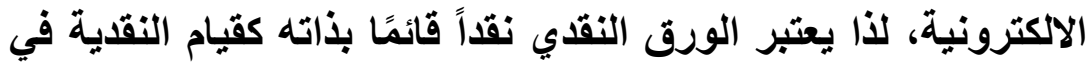

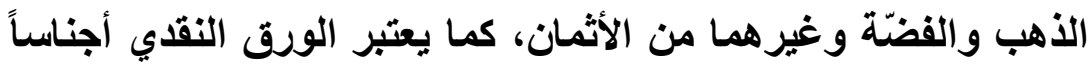

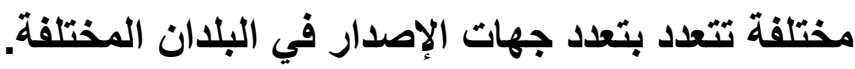

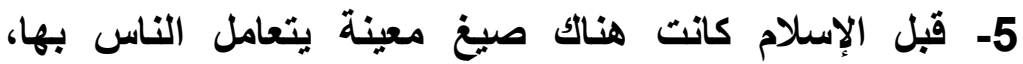

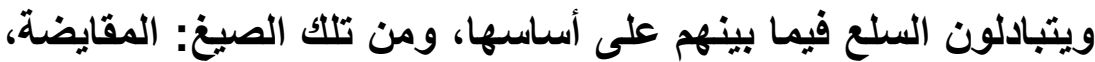
النقود السلعية، النقود المعدنية.

6- تكمن وظائف النقود في نظر أهل الاقتصاد في أنها: وحدة

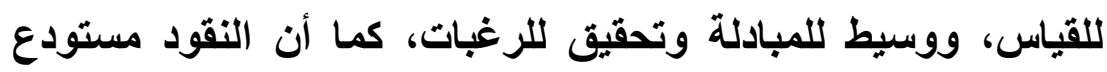
لثروة أو أداة لاختزان القيم. 
7- لم تقف النقود في العصر الحديث عند النقود المعدنية، وإنما انتقلت إلى الورقية والمصرفية، والنقود الورقية تتنوع إلى نقود النقد نائبة، ونقود وثيقة، ونقود إلزامية.

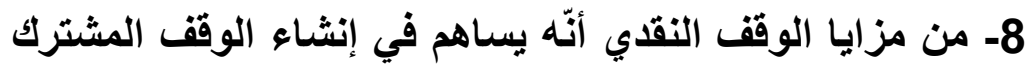

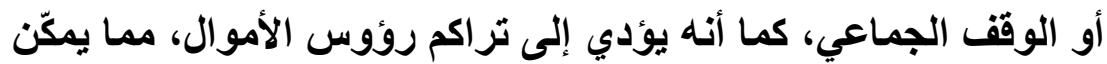

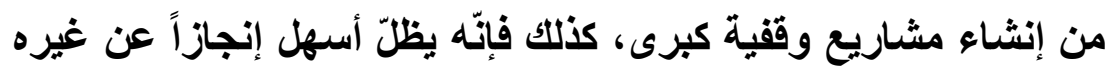
بالنسبة للواققين؛ لوفرة النقاء في يد العدد الأكبر من الناس، كما أنها

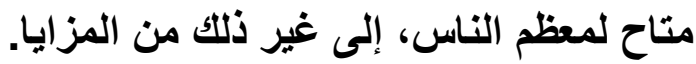

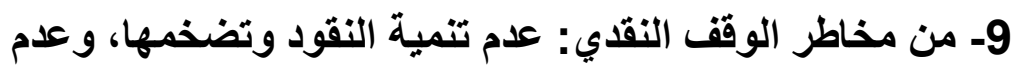

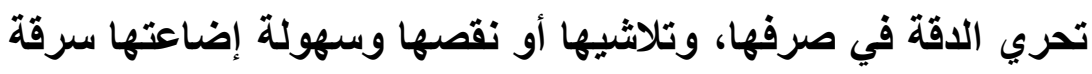
أو نهباً أو غصباً أو نحو ذلكة وتلك. 10- للوقف النقاي أنواع وصور منها: الوقف النقدي الاستثماري، الوقف الإيرادي، الوقف النقائ النقي القرضي.

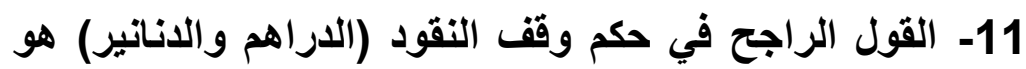

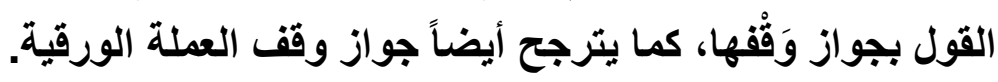

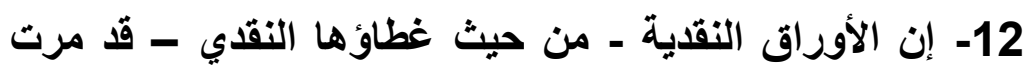

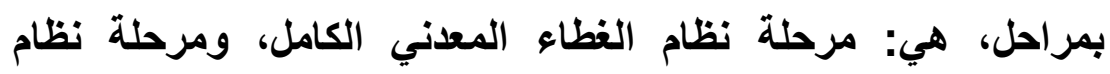

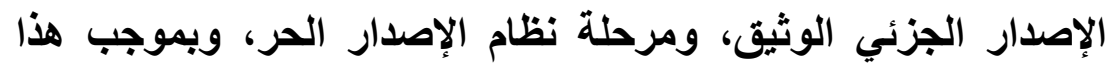

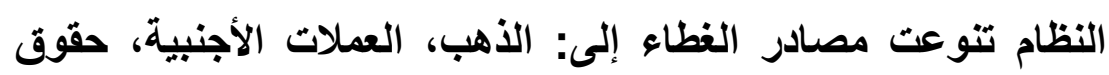

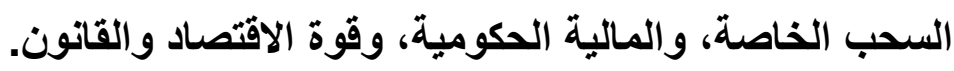

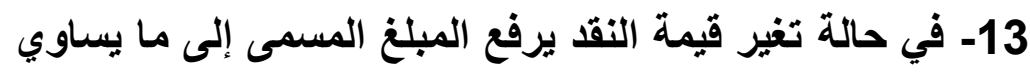

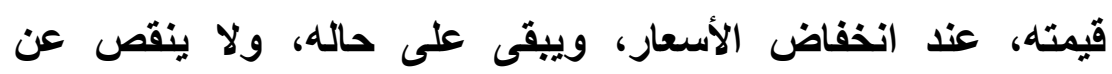
المسمى عند ارتفاع قيمة النقا.

14- لا مانع من تحديد مخصصات لمواجهة ما يطرأ على الأموال

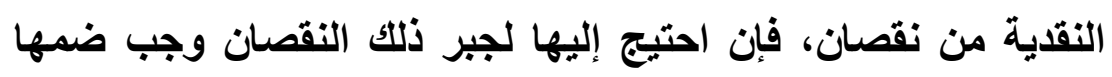
إلى رأس مال الوقف، وإن لم يحتج إليها انتفع بها في أي جهة من فن إن إنهان جهات الوقف. 
15- لا مانع من استثمار النقّ استثمارًا مأمونًا يوفر عائدًا نافعًا؛ وذللك لأن وقف النقود ليس مقصودًا لعينه، بل لما يكون له من أثر في نفع الجهة الموقوف عليها، ولا يتحقق هذا النفع إلا بتفعيل هذه النقود

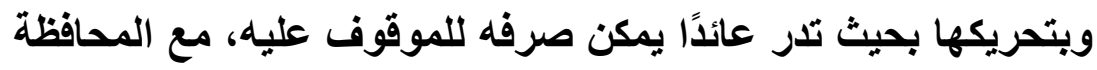
على القيمة الشرائية للنقا.

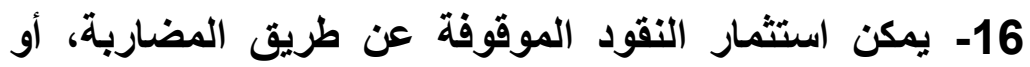

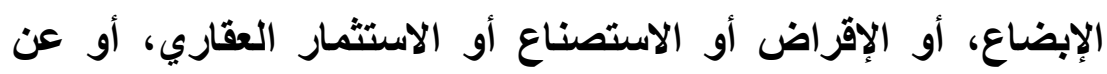
طريق الثركات الأخرى المشروعة، إلى غير ذلك وجوه الاستثمار الإن الإن الإن

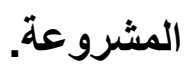

17- لا يجوز استثمار النقود الموقوفة في البنوك التي تتعامل

$$
\text { بالفوائد الربوية. }
$$

وبعد ، فما كان من توفيق فمن الله، وما كان من سهو أو خطأ

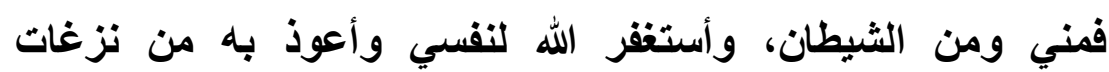

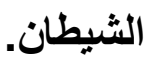

والحمد لله في الأولى والآخرة، وأسأله ـ سبحانه وتعالى ـ العفو و المغفرة. وصلى الله وسلم وبارك على سيدانا محمد وعلى آله وصحبه ومن تبعهم بإحسان إلى يوم الدين. 


$$
\begin{aligned}
\text { أولا - كتب التفسير وعلومه: } &
\end{aligned}
$$

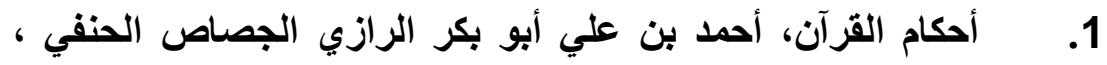

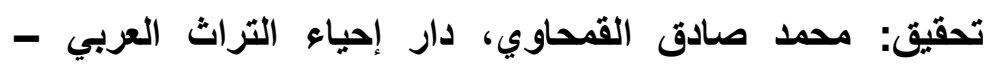

$$
\text { بيروت. }
$$

2. تفسير المراغي، لأحمد بن مصطفى المراغي ، شركة مكتبة ومطبعة مصطقى البابى الحلبي وأولاده بمصر، طم: الأولى، 1365 هـ 1365

هـ - 1946 .

تفسير النسفي (مدارك التنزيل وحقائق التأويل)، لأبي البركات عبد .3 الله بن أحمد النسفي ، حققه: يوسف علي بليوي، راجعه وقدام لله:

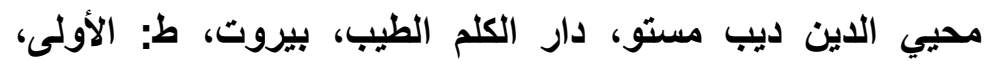
1419 هـ - 1998 م. 1919 م. جامع البيان عن تأويل آي القرآن، لمحمد بن جرير الطبري، .4

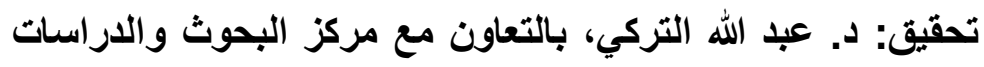

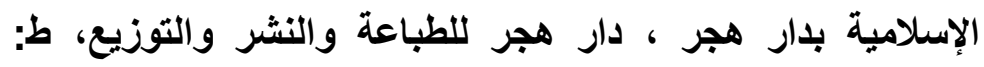

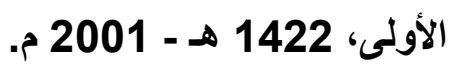
زهرة التفاسير، محمد بن أحمد (أبو زهرة) ، 1394هـ، دار الفكر .5 العربي. فتحُ البيان في مقاصد القرآن، لأبي الطيب محمد صديق خان .6

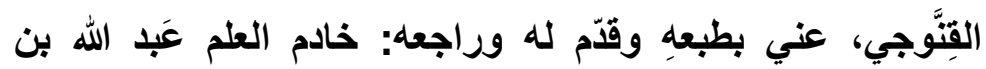

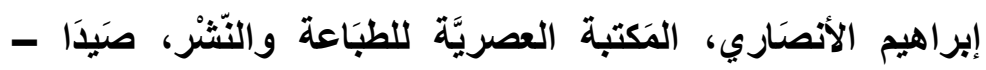

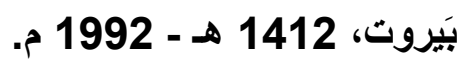

7. معالم التنزيل في تفسير القرآن ، للحسين بن مسعود البغوي ،

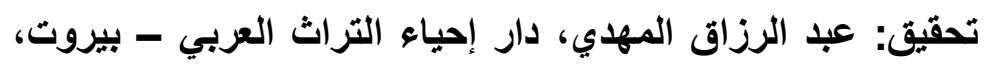

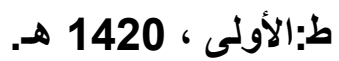
النكت والعيون، لأبي الحسن علي بن محمد الماوردي ، تحقيق: .8

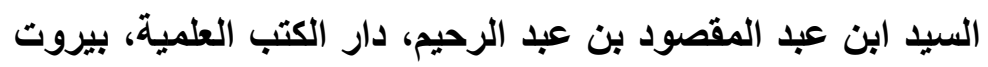


ثانيا-كثب الحديث وعلومه:

إحكام الإحكام شرح عمدة الأحكام، لابن دقيق العيد، مطبعة السنة

المحمدية، بدون طبعة وبدون تاريخ.

10. الإحكام شرح أصول الأحكام، لعبد الرحمن بن بارئ محمد بن قاسم

النجدي ، ط:الثانية، 1406 هـ الأئ

إرشاد الساري لشرح صحيح البخاري، لأحمد بن محمد القسطلاني

، المطبعة الكبرى الأميرية، مصر، ط: السابعة، 1323 هـ.

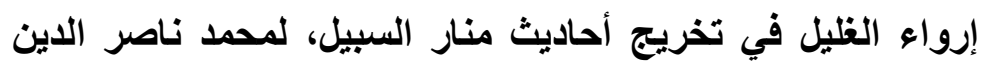

الألباني ، إثراف: زهير الثداويش، المكتب الإسلامي - بيروت، ط:

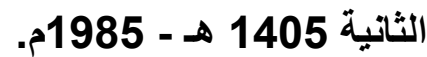

البلر المنير في تخريج الأحاديث والأثار الواقعة في الثرح الكبير،

لأبي حفص عمر بن الملقن ، تحقيق: مصطفى أبو الغيط وآخرون، الإدئ

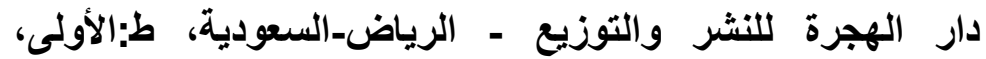

1425هـ-2004م.

14. التحجيل في تخريج ما لم يخرج من الأحاديث والآثار في إرواء

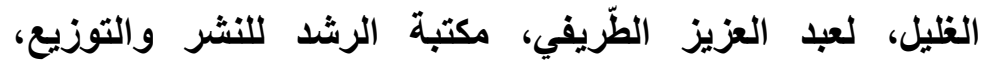

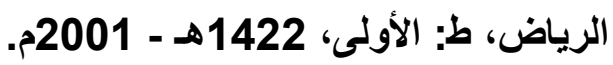

التكميل لما فات تخريجه من إرواء الغليل، لصالح بن عبد العزيز آل

الثيخ، دار العاصمة للنشر والتوزيع، الرياض، ط: الأولى، 1417

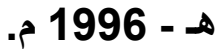

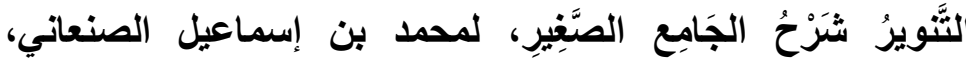

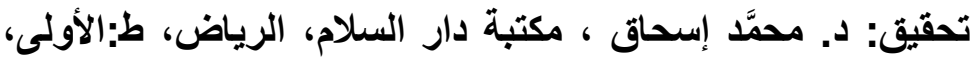

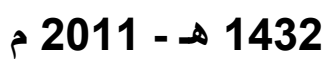

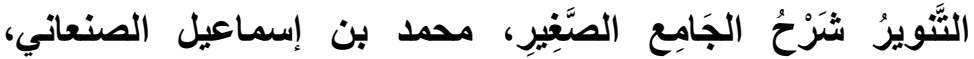
تحقيق: د. محمَّد إبراهيم، مكتبة دار السلام، الرياض، ط: الأولى،

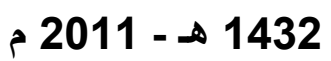

التوضيح لشرح الجامع الصحيح، لأبي حفص ابن الملقن ، تحقيق:

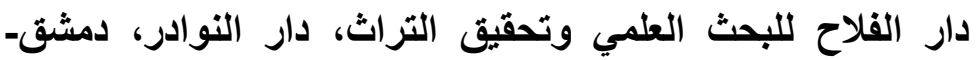

$$
\text { سوريا، ط: الأولى، لإجل } 1429 \text { هـ - } 2008 \text { م. }
$$


التيسير بشرح الجامع الصغير، لزين الدين الحدادي، مكتبة الإمام

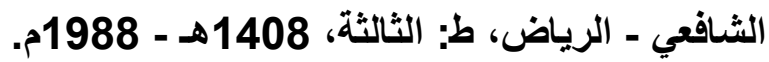

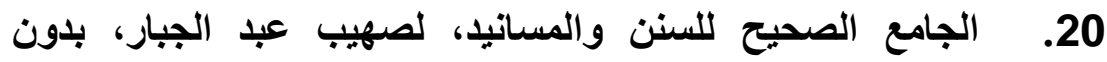

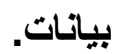

21. الجامع المسند الصحيح المختصر من أمور رسول الله ع وسننه

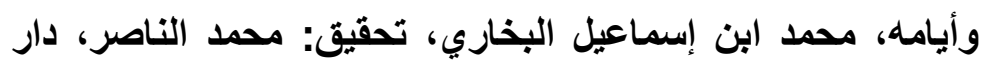

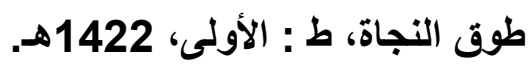

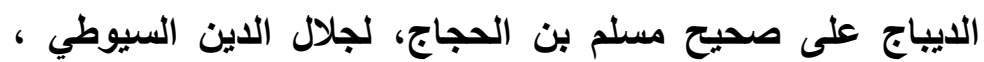

.22

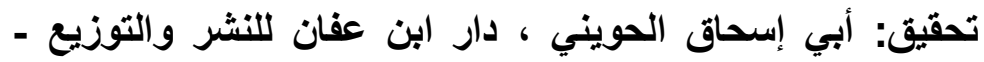
المملكة العربية السعودية ـ الخبر، ط: الأولى 1416 هـ - 1996

مبل السلام، لمحمد بن إسماعيل الصنعاني، دار الحديث، بدون .23 طبعة وبدون تاريخ.

24. سنن الترمذي، لمحمد بن عيسى بن سَوْرة الترمذي ، تحقيق: أحمد

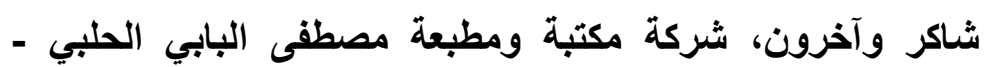

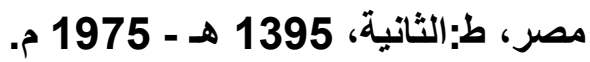
السنن الصغير للبيهقي، لأحمد بن الحسين الخُسْرَوْجِردي البيهُِي،

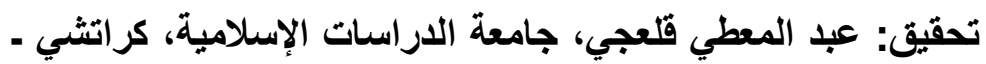

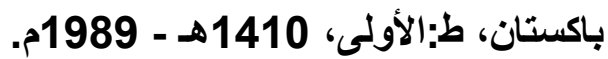

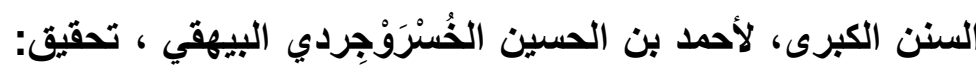
محمد عبد القادر عطا، دار الكتب العلمية، بيروت ـ لبنات، ط:

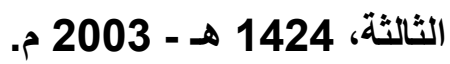

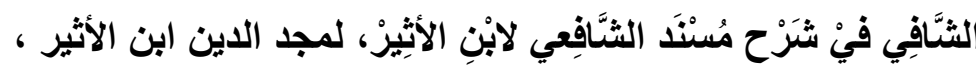

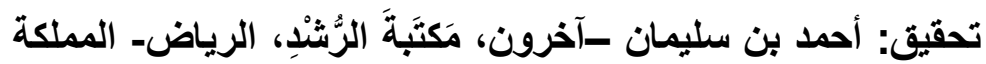

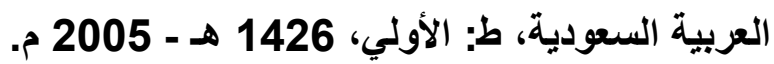

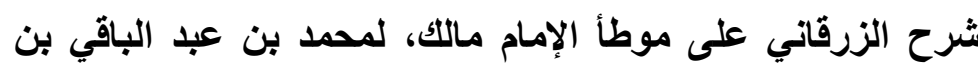
.28

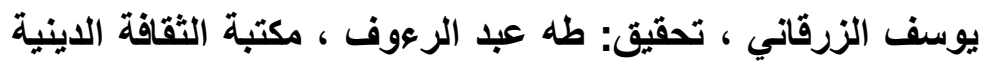
ـ القاهرة، ط: الأولى، 1424هـ - 2003م. 


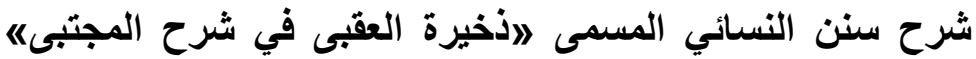
.29

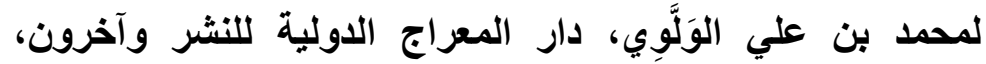

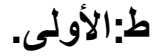

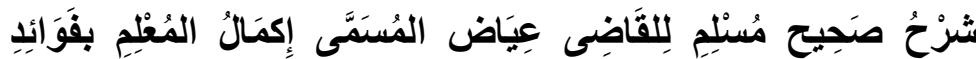
.30

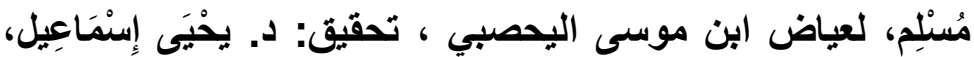

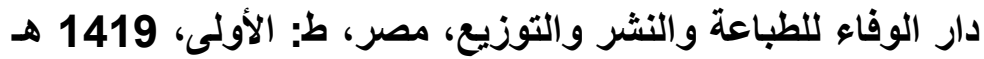
1998 -

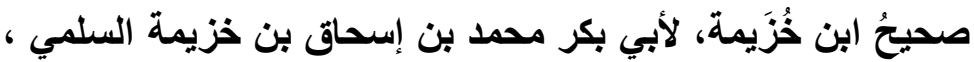
.31

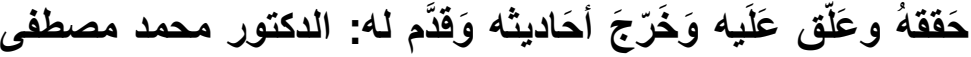

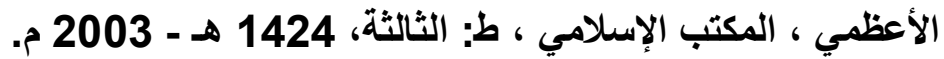
عون المعبود شرح سنن أبي داود، ومعه حاثية ابن القيم: تهذيب .32

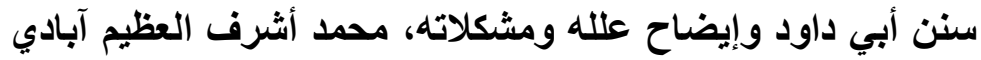
، دار الكتب العلميةت بيروت، ط: الثانية، 1415 هـ.

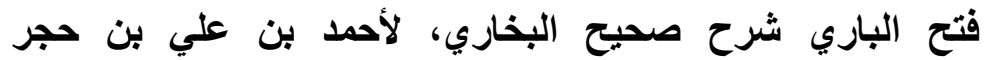
.33

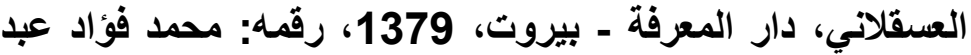

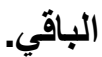
فيض الباري على صحيح البخاري، لمحمد أنور شاه، تحقيق: محمد .34 الميرتهي، دار الكتب العلمية بيروت ـ لبنان، ط:الأولى، 1426 هـ 2005 -

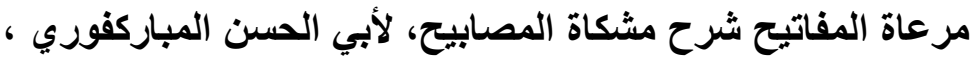
.35

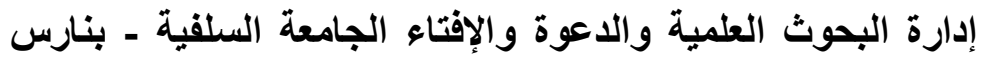
الهند، ط: الثالثة - 1404 هـ، 1984 م. 1984 م. مرقاة المفاتيح شرح مشكاة المصابيح، لأبي الحسن نور الدين الملا .36

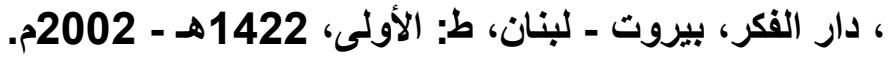
المستدرك على الصحيحين، لأبي عبد الله الحاكم النيسابوري، تحقيق: مصطفى عطا، دار الكتب العلمية - بيروت، ط: الأولى،

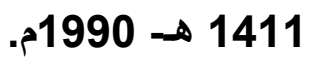
مسند الإمام أحمد بن حنبل، لأحمد بن محمد بن حنبل الثيباني، .38

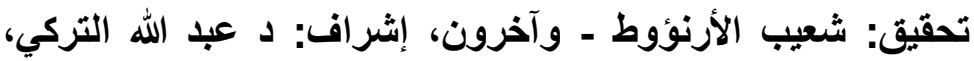

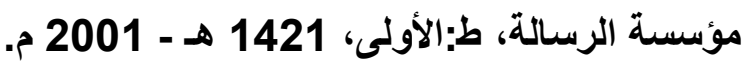


مسند الحميدي، لعبد الله بن الزبير الحميدي ، حقق نصوصه وخرج

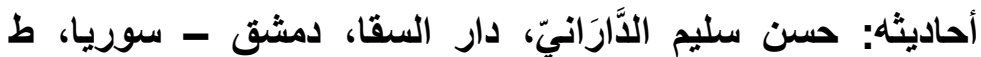

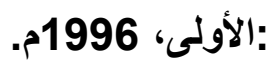

المسند الصحيح المختصر بنقل العدل عن العدل إلى رسول الله ع،

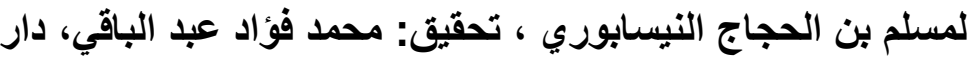

$$
\text { إحياء التزاث العربي - بيروت. }
$$

المسند، لمحمد بن إدريس الثافعي، دار الكتب العلمية، بيروت ـ

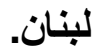

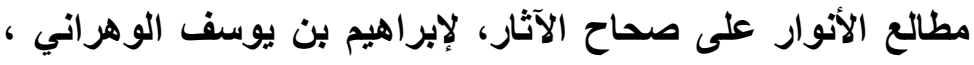

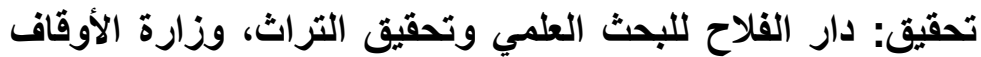

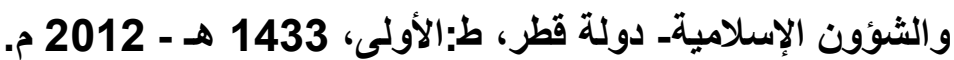

المعجم الأوسط، لسليمان بن أحمد بن أيوب الطبراني ، تحقيق: طارق بن عوض الله ، وآخرون، دار الحرمين ــ القاهرة.

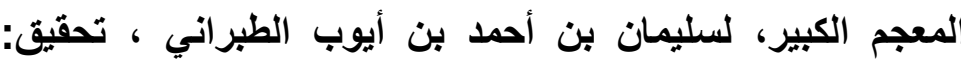
حمدي السلفي، مكتبة ابن تيمية ـ القاهرة، ط:الثانية.

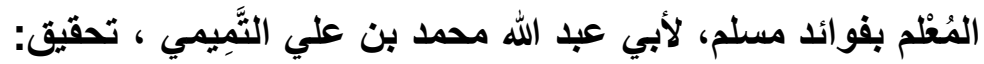

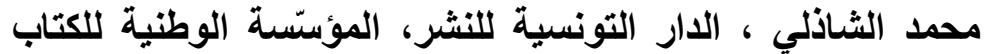

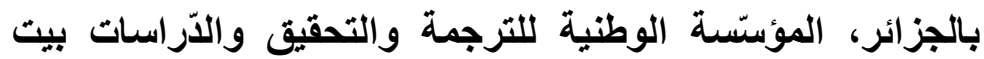
الحكمة، ط:الثانية، 1988 م.

منار القاري شرح مختصر صحيح البخاري، لحمزة قاسم، راجعه: .46

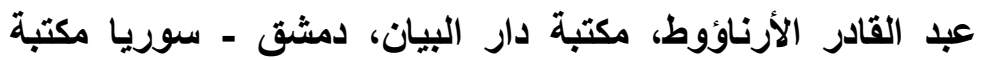
المؤيد، الطائف ـ المملكة العربية السعودية، 1410 هـ - 1990 م.

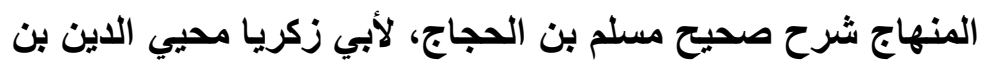
شرف النووي ، دار إحياء التراث العربي - بيروت، ط: الثانية،

نيل الأوطار، لمحمد بن علي الثوكاني ، تحقيق: عصام الدين

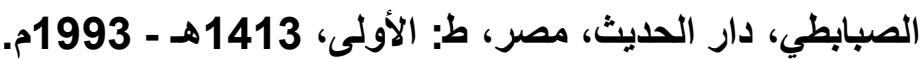




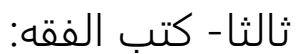

الفقه الحنفي

49. الأحكام السلطاتية، لأبي الحسن علي بن محمد البذادي، الشهير

$$
\text { بالماوردي، دار الحديث ــ القاهرة. }
$$

50.

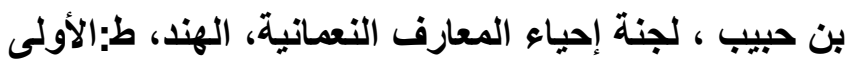

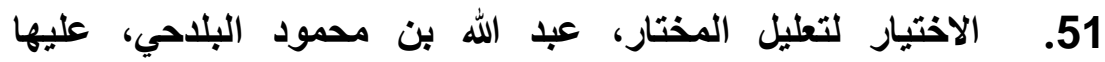

تعليقات: الثيخ محمود أبو دقيقة ، مطبعة الحلبي - القاهرة ،

1356 هـ - 1937 م 1937

52.

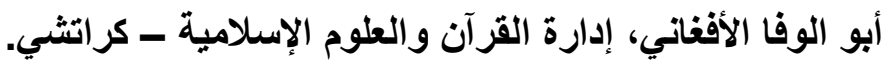

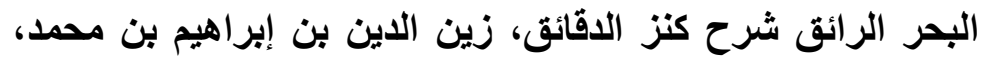

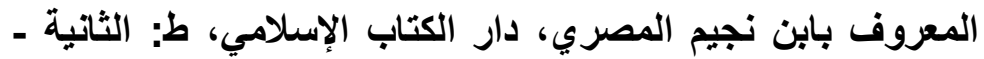

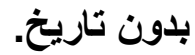

54.

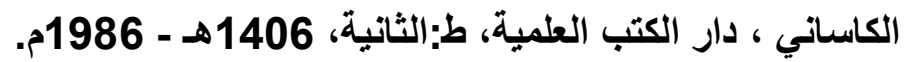

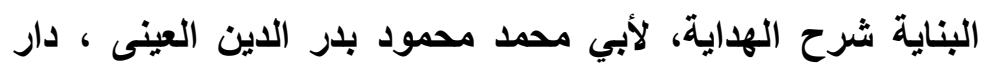

.55

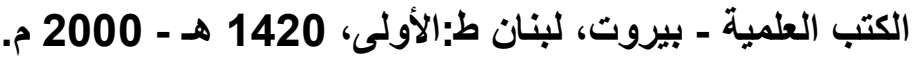

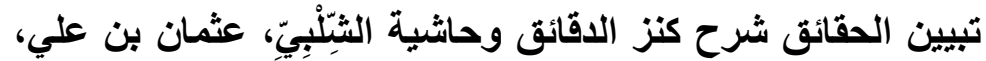

.56

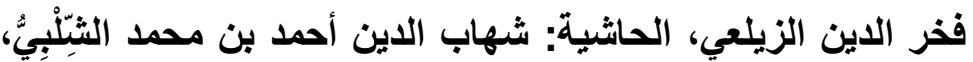

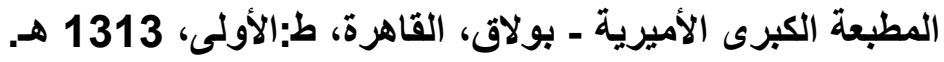

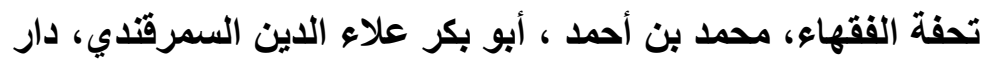

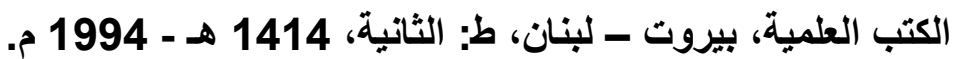

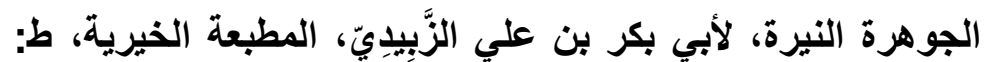

.58

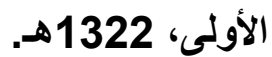

الار المختار شرح تنوير الأبصار وجامع البحار، محمد بن علي

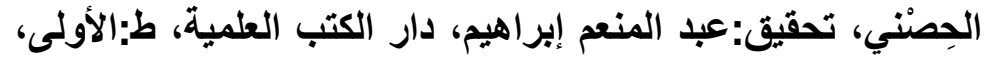

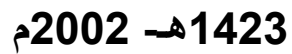


60. درر الحكام شرح غرر الأحكام، محمد بن فرامرز بن علي الشهير

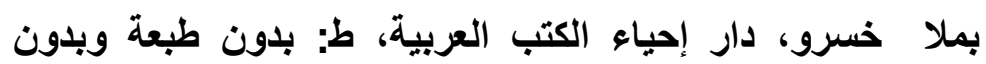
تاريخ.

رد المحتار على الدر المختار، ابن عابدين، محمد أمين بن عمر .61

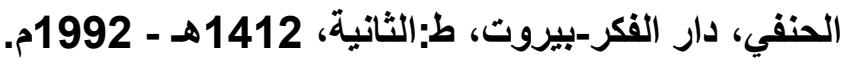
العناية شرح الهاية، محمد بن محمد بن محمود، أكمل الدين .62 البابرتي، دار الفكر، بدون طبعة وبدون تاريخ.

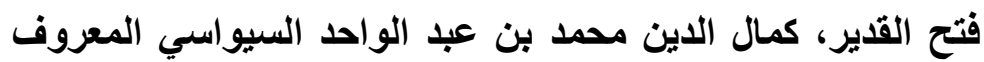
.63 بابن الهمام، دار الفكر، بدون طبعة وبدون تاريخ.

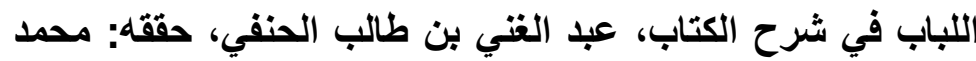
.64

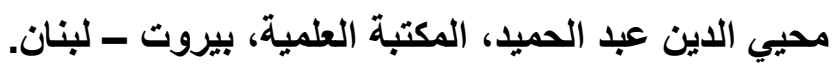

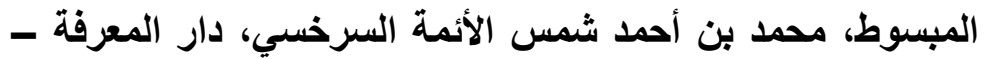
.65

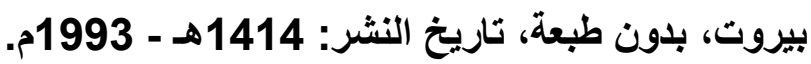

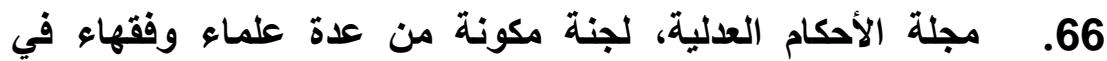
الخلافة العثمانية، تحقيق: نجيب هواويني، وآخرون، آرام باغ، وكنه كراتثي. مجمع الأنهر في شرح ملتقى الأبحر، إبراهيم بن محمد الحَلَبي .67

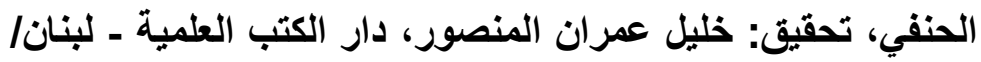

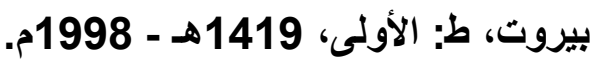
المحيط البرهاني في الفقه النعماني فقه الإمام أبي حنيفة، لأبي الماني .68

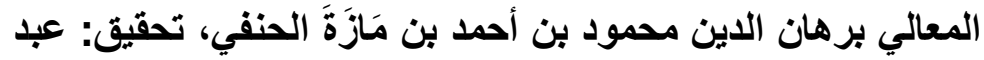
الكريم الجندي، دار الكتب العلمية، بيروت ــ لبنان، ط:الأولى، بمدي،

النهر الفائق شرح كنز الدقائق، سراج الدين عمر بن إبراهيم .69

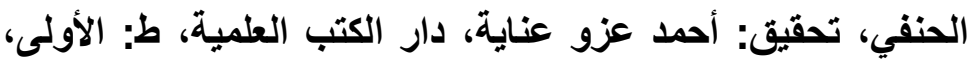
1422هـ - 2002م.

70. تحقيق: طلال يوسف، دار احياء التراث العربي - بيروت - لبنان. 


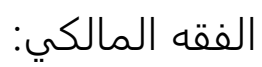

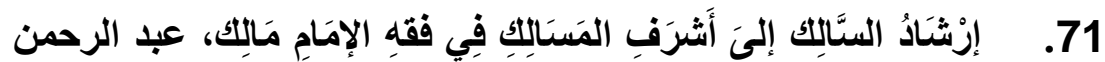

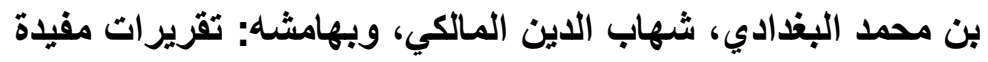
لإبراهيم بن حسن، شركة مكتبة ومطبعة مصطفى البابي الحلبي وأولاده، مصر، ط:الثالثة. 72.

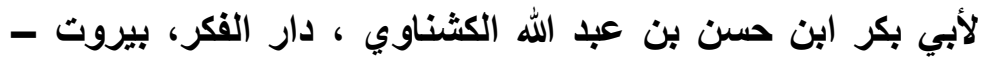
لبنان، ط:الثانية. 73. بلغة السالك لأقرب المسالك، المعروف بحاثية الصاوي على الثرح

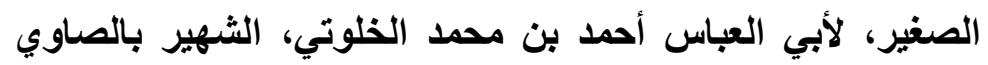
المالكي، دار المعارف، بلون طبعة وبدون تاريخ. 74.

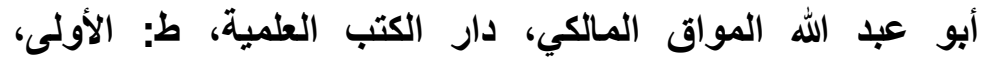

75. التنبيه على مبادئ التوجيه ـ قسم العبادات ، لأبي الطاهر إبراهيم

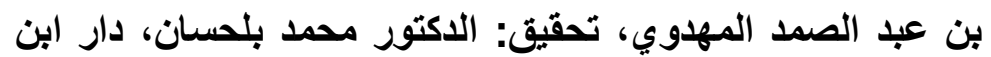

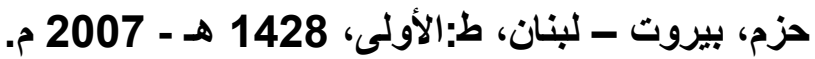
76.

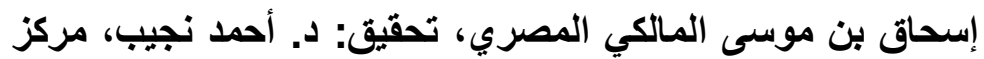

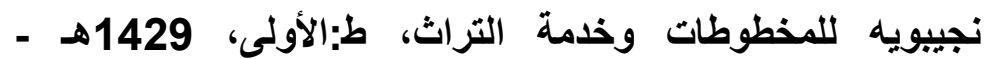
2008م. 2008

77. الاسوقي المالكي، دار الفكر، بلون طبعة وبلدون تاريخ. 78.

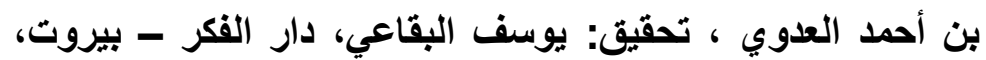

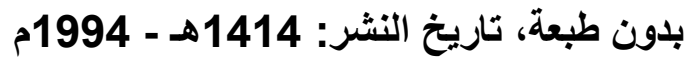
79. الخلاصة الفقهية على مذهب السادة المالكية، محمد العربي

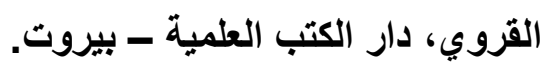


الأخيرة، لأبي العباس أحمد بن إدريس الثهير بالقرافي، تحقيق: .80

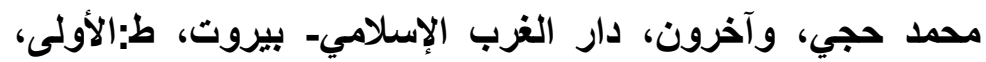
1994 م.

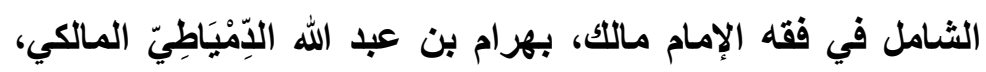
.81

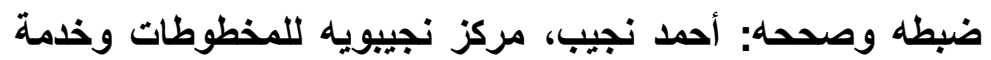

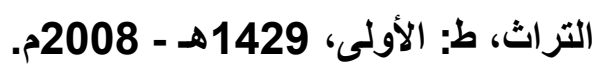
الثرح الصغير على أقرب المسالك إلى مذهب الإمام مالك، لأحمد .82

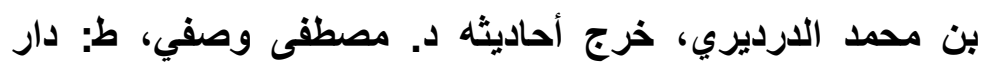
المعارف.

شرح مختصر خليل للخرشي، محمد بن عبد الله الخرشي المالكي، .83 دار الفكر للطباعة ـ بيروت، بدون طبعة وبدون تاريخ.

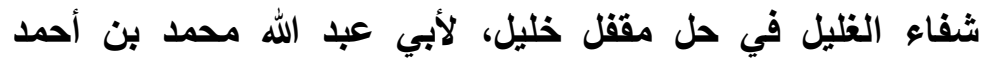
.84

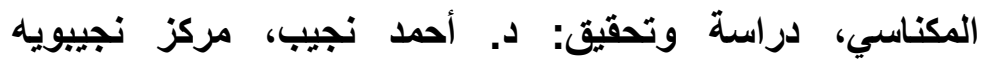

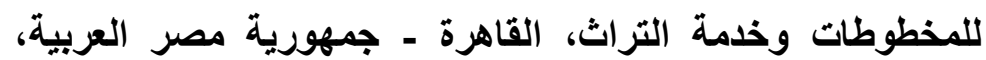
ط:الأولى، 1429 هـ - 2008 م. عقد الجواهر الثمينة في مذهب عالم المدينة، لأبي محمد جلال الدين .85

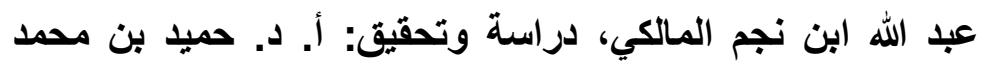

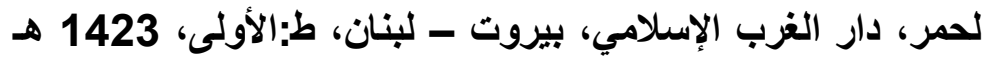

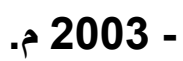
عقد الجواهر الثمينة في مذهب عالم المدينة، لأبي محمد جلال الدين .86

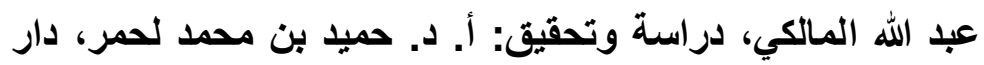

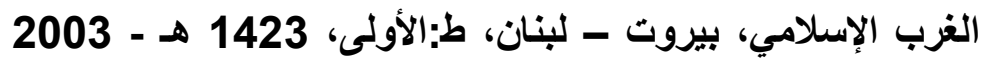
الفواكه الدواني على رسالة ابن أبي زيد القيرواني، أحمد بن غانم .87

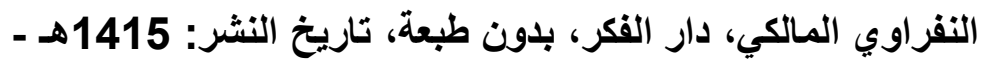
1995م. المدونة، مالك بن أنس الأصبحي المدني، دار الكتب العلمية، ط: .88 الأولى، 1415 14هـ - 1994م. المعونة على مذهب عالم المدينة لالإمام مالك بن أنسها، لأبي .89 محمد عبد الوهاب البغدادي المالكي، تحقيق: حميش عبد الحقّ، 
المكتبة التجارية، مصطفى أحمد الباز - مكة المكرمة، أصل الكتاب:

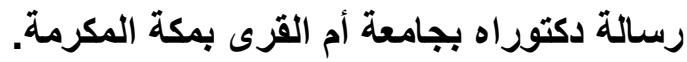

90.

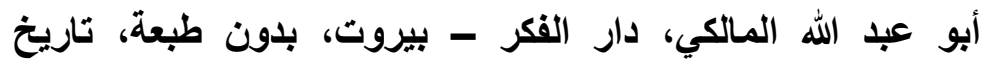

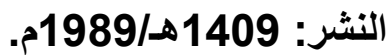

91. مواهب الجليل في شرح مختصر خليل، شمس الدين محمد بن محمد

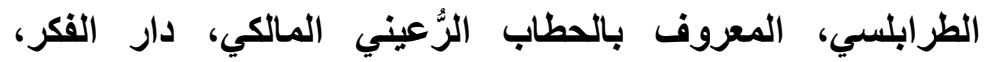

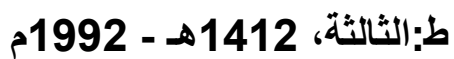

92.

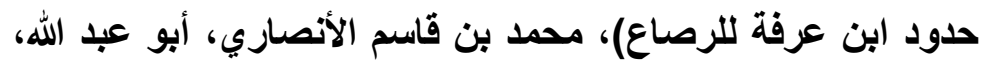

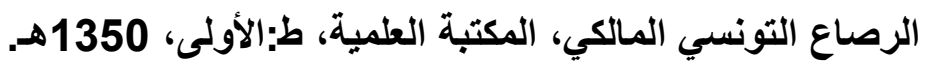
الفقه الثنافعي:

93. أسنى المطالب في شرح روض الطالب، زكريا بن محمد بن زكريا

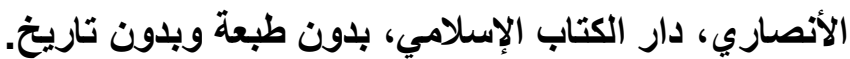

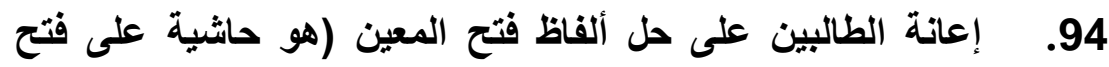

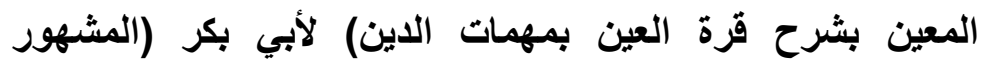

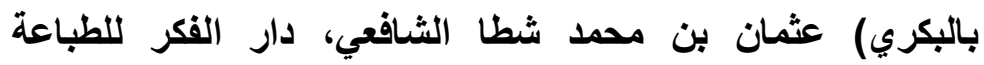
والنشر، ط:الأولى، 1418 هـ - 1997 م. 95. الإقناع في الققه الثافعي، لأبي الحسن علي بن محمد البغدادي، الثهير بالماوردي، بدون بيانات.

96. الإقناع في حل ألفاظ أبي شجاع، شمس بأبات الدين، محمد بن أحمد

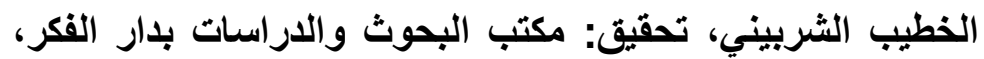

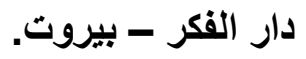

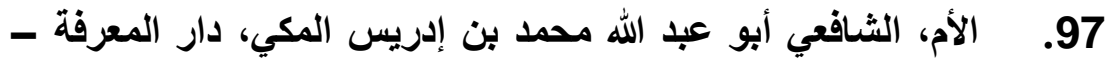

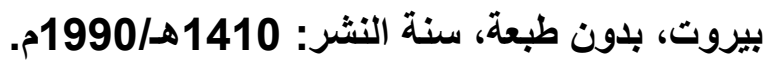
98.

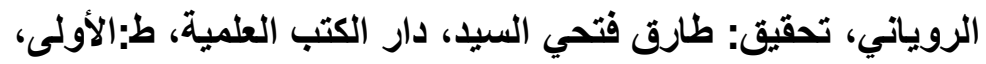


99. البيان في مذهب الإمام الثافعي، لأبي الحسين يحيى بن أبي الخير

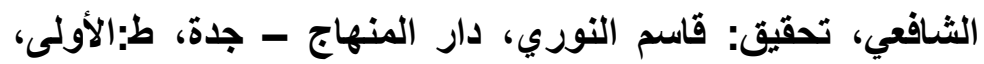

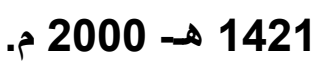

100. التجريد لنفع العبيد = حاشية البجيرمي على شرح المنهج، سليمان

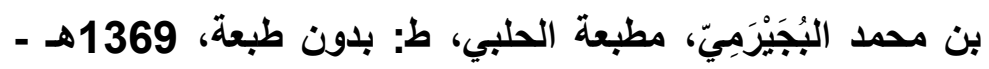
1950م. بن محم.

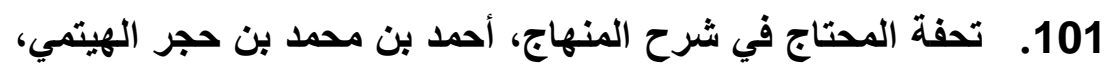

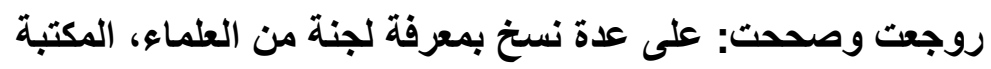

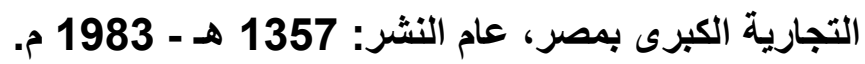
102. جواهر العقود ومعين القضاة والموقعين والثهود، شمس علمس الدين

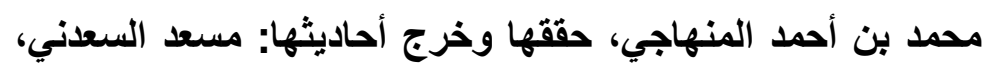
دار الكتب العلمية بيروت ـ لبنان، ط:الأولى، 1417 هـ - 1996

103. حاثيتا قليوبي وعميرة، أحمد سلامة القليوبي، وأحمد البرلسي

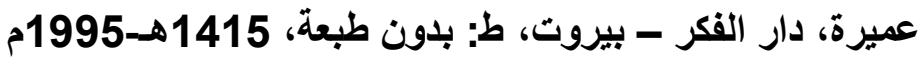

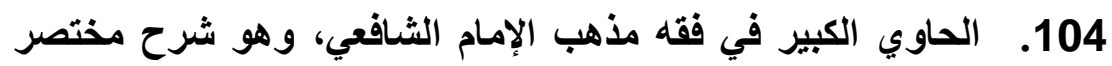

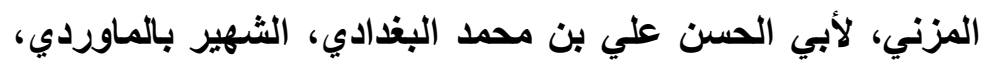

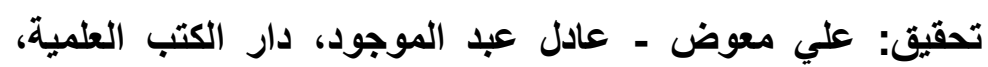

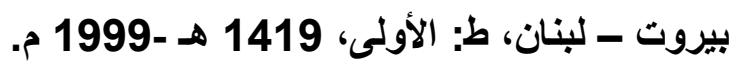
105. الحاوي للفتاوي، عبد الرحمن بن أبي بكر، جلال الدين الأل السيوطي،

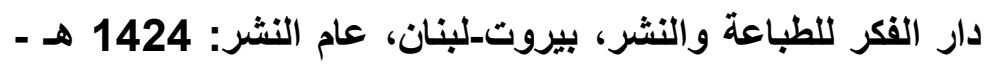

2004

106. روضة الطالبين وعمدة المفتين، لأبي زكريا يحيى بن شرف

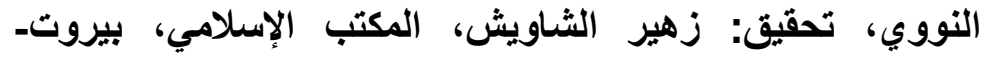

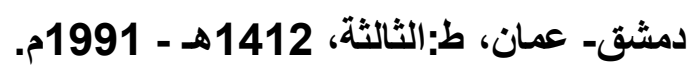
107. السراج الوهاج على متن المنهاج، العلامة محمد الزهري الغمراوي، دار المعرفة للطباعة والنشر - بيروت.

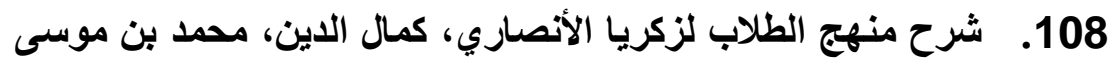

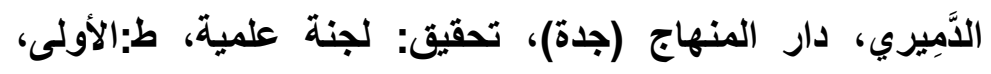


109. العزيز شرح الوجيز (الثرح الكبير)، عبد الكريم القزويني، تحقيق:

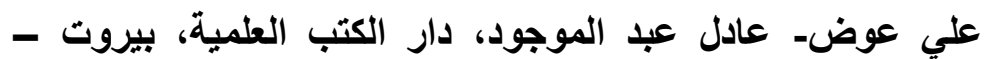

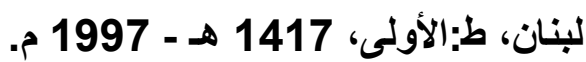

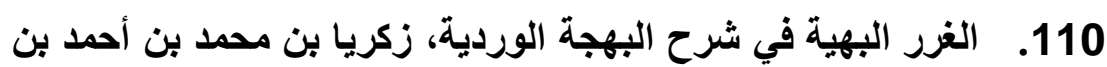

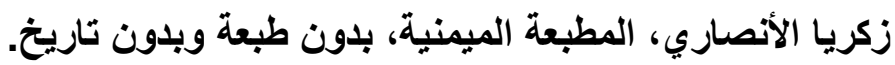

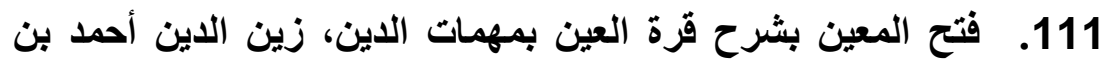

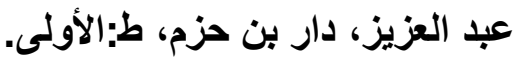

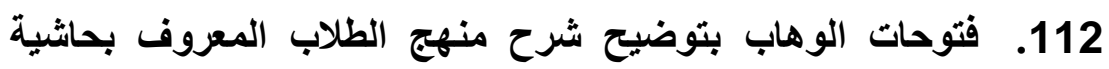

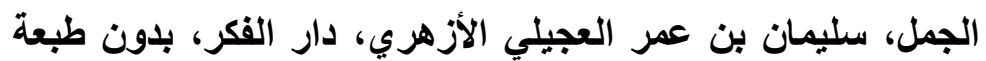
وبدون تاريخ.

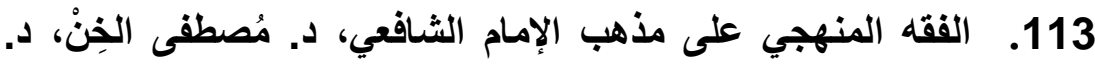

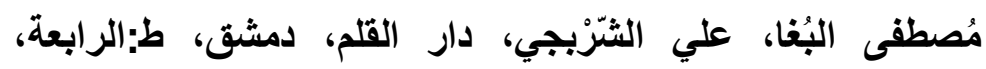
1413 هـ - 1992 م. 114. كفاية النبيه في شرح التتبيه، أحمد بن محمد بن علي الأنصاري،

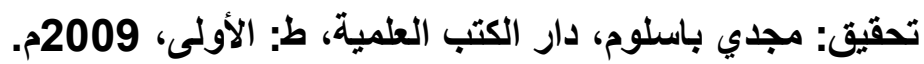

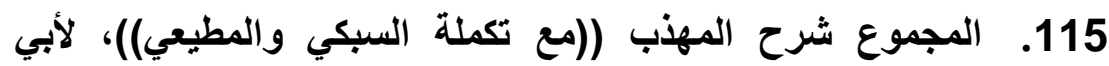
زكريا يحيى بن شرف النووي، دار الفكر.

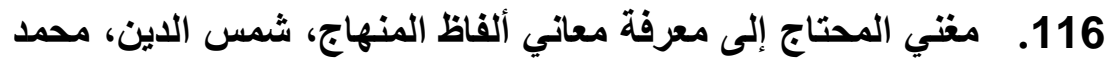

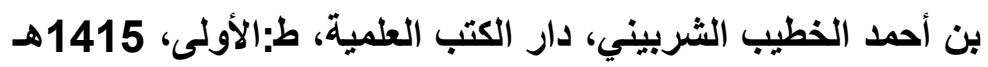
1994 -

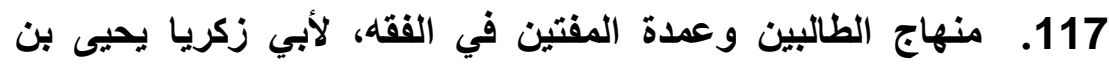

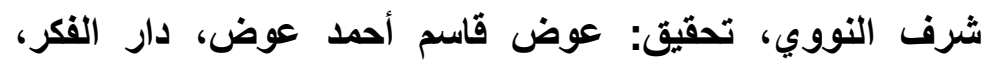

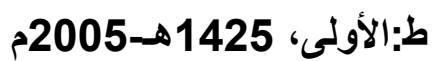
118. المهذب في فقه الإمام الثافعي، لأبي إسحاق إبراهيم بن علي الثنيرازي، دار الكتب العلمية.

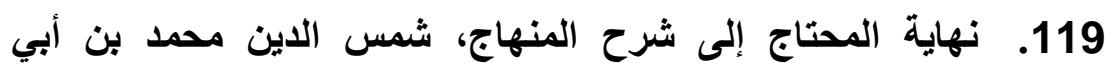
العباس الرملي، ، دار الفكر، بيروت، طبعة أخيرة - 1404هـ العـ 
120. نهاية المطلب في دراية المذهب، عبد الملك الجويني، الملقب بإمام

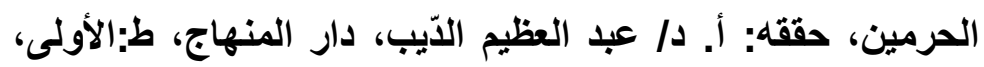

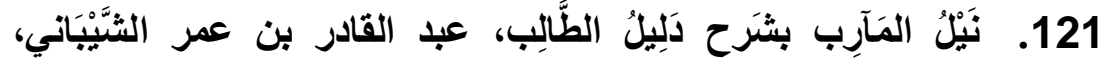
تحقيق: د. محمد الأشقر، مكتبة الفلاح، الكويت، ط:الأولى، 1403

هـ - 1983م.

122. الوسيط في المذهب، لأبي حامد الغزالي، تحقيق: أحمد محمود

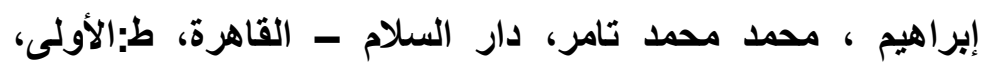
1417هـ. الفقه الحنبلي:

123. الأسئلة والأجوبة الفقهية، لأبي محمد عبد العزيز السلمان، بدون بيانات.

124. إعلام الموقعين عن رب العالمين، ابن قيم الجوزية، تحقيق: محمد

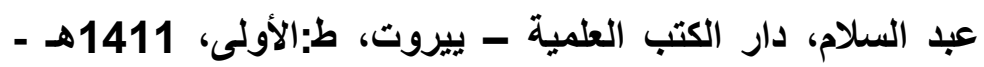

1991

125. الإقناع في فقه الإمام أحمد بن حنبل، موسى بن أحمد الحجاوي، تحقيق: عبد اللطيف السبكي، دار المعرفة بيروت ـ لبنان.

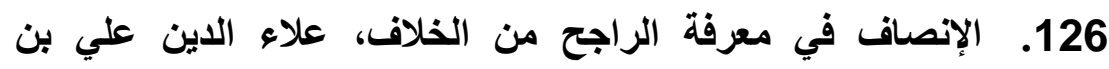

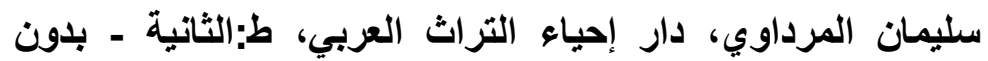
تاريخ.

127. حاثية الروض المربع شرح زاد المستقنع، ، عبد الرحمن بن محمد الحنبلي النجدي، (بدون ناشر)، ط:الأولى - 1397 هـ.

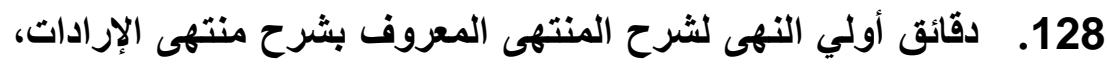

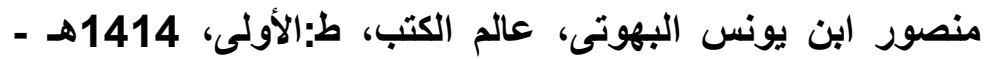

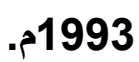

129. الروض المربع شرح زاد المستقتع، منصور بن يونس البهوتى،

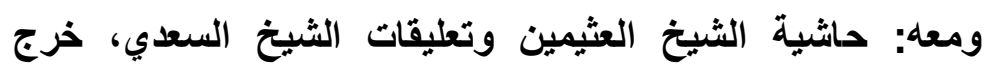
أحاديثه: عبد القدوس محمد نذير، دار المؤيد - مؤسسة الرسالة.

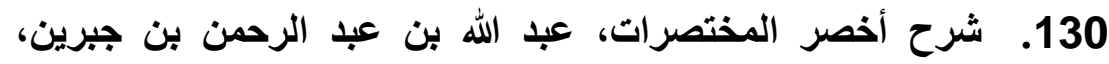
دروس صوتية. 
131. شرح الزركثي، شمس الدين محمد بن عبد الله الزركثي، دار العبيكان، ط:الأولى، 1413 هـ - 1413 هـ 1993 م.

132. الثرح الكبير على متن المقتع، عبد الرحمن بن محمد بن قدامة المقدس، دار الكتاب العربي للنشر والتوزيع، أشرف على على طباعته: محمد رشيد رضا صاحب المنار.

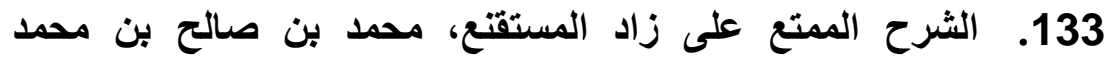

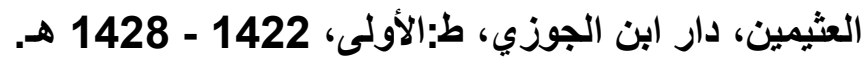
134. شرح زاد المستقنع، محمد بن محمد المختار الثنقيطي، دروس، لالاول صوتية.

135. العدة شرح العمدة، عبد الرحمن بن إبراهيم المقدس، دار الحديث،

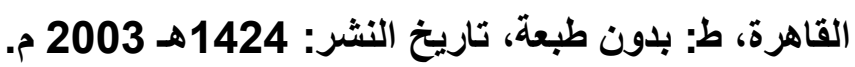
136. العدة شرح العمدة، عبد الرحمن بن إبراهيم بن أحمد، المقدسي، دارئ دار

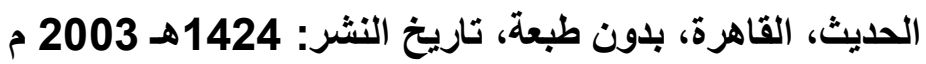

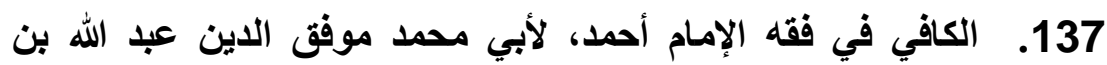

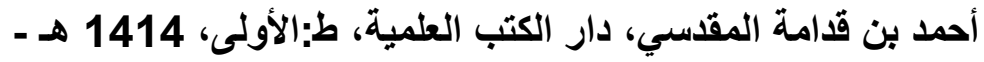
1994 م. 138. الكافي في فقه الإمام أحمد، لأبي محمد موفق الدين عبد الله بن

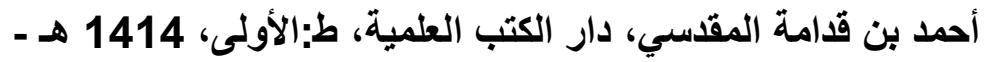
1994 م. 139. كتاب الفروع ومعه تصحيح الفروع لعلي المرداوي، محمد بن مفلح

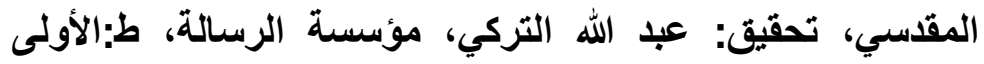

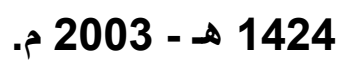
140. كثاف القناع عن متن الإقناع، منصور بن يونس البهوتى، دار الكتب العلمية.

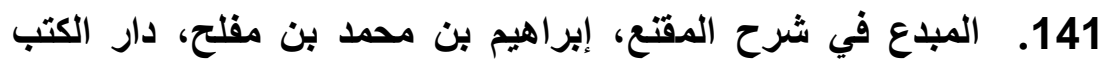

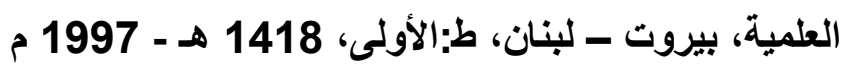
142. متن الخرقي على مذهب أبي عبد الله أحمد بن حنبل الثيباني، لأبي

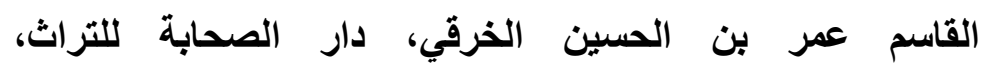
ط:1413 هـ-1993م. 
143. مجموع الفتاوى، تقي الدين أحمد بن عبد الحليم بن تيمية الحراني،

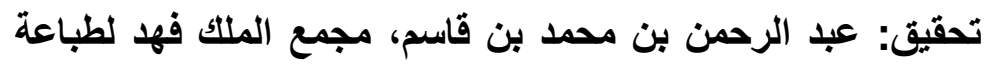

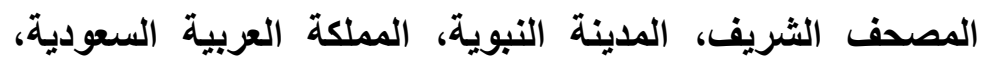
1416هـ-1995م. 144. المحرر في الققه على مذهب الإمام أحمد بن حنبل، عبد السلام بن

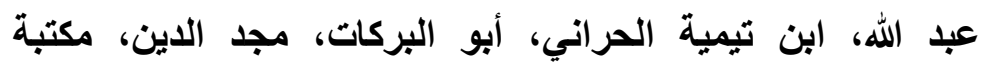

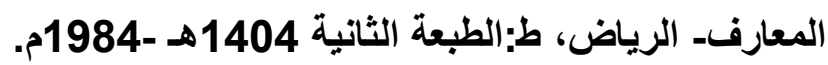

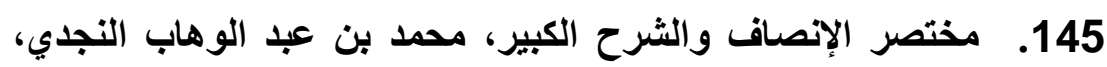

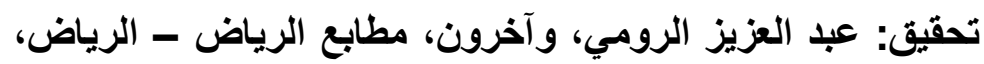
ط:الأولى.

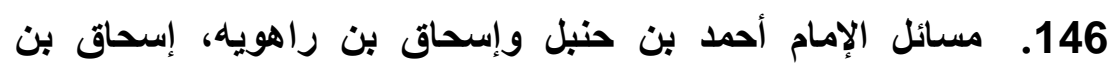

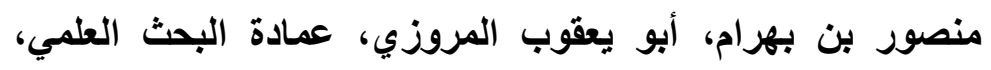
الجامعة الإسلامية بالمدينة المنورة، المملكة العربية السعودية العمدية،

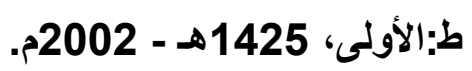

147. مطالب أولى النهى في شرح غاية المنتهى، مصطفى بن سعد بن

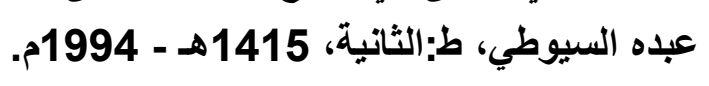

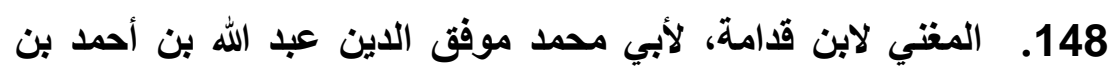

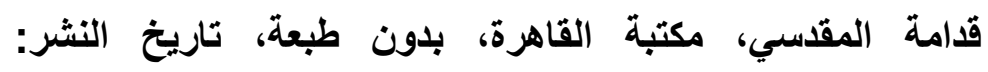

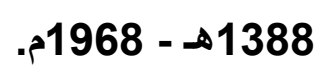

149. الملخص الفقهي، صالح بن فوزان الفوزان، دار العاصمة، الرياض،

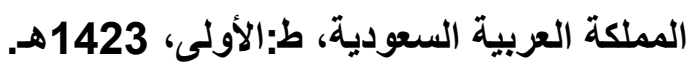

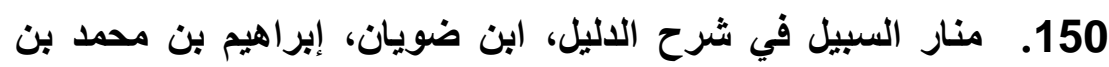

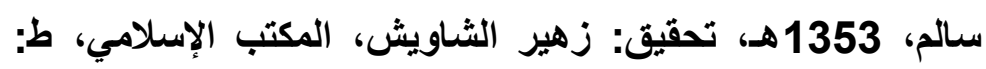

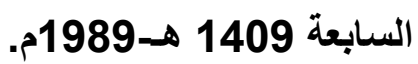

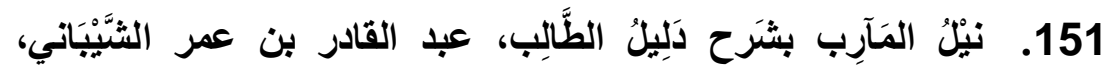

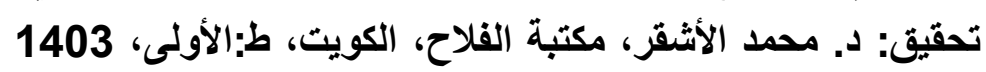
هـ - 1983م. 152. الهاية على مذهب الإمام أحمد بن حنبل، لمحفوظ بن أحمد، أبو

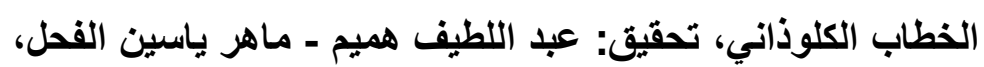
مؤسسة غراس للنشر والتوزيع، ط:الأولى، 1425 هـ - 14204 هـ 2004 م. 
153. الوقوف والترجل من الجامع لمسائل الإمام أحمد، لأحمد بن محمد

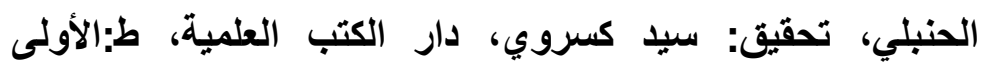

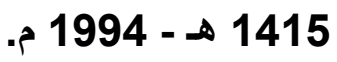

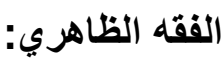

154. المحلى بالآثار، لأبي محمد علي بن أحمد حزم الظاهري ، دار الفكر بلري

- بيروت، بلون طبعة وبدون تاريخ.

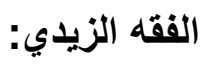

155. السيل الجرار المتدفق على حدائق الأزهار- للشوكاني، تحقيق:

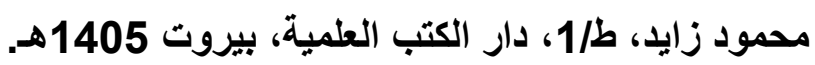

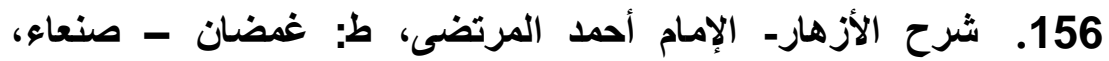

1400 هـ

الفقه الإمامي:

157. تذكرة الفقهاء- ليوسف الحلي، ط: المكتبة الرضوية لإحياء الآثار

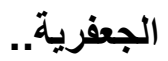

158. جامع الخلاف والوفاق، علي بن محمد القي،، لحسين الحسيني

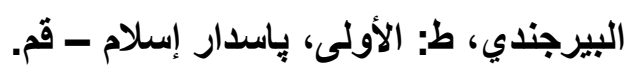

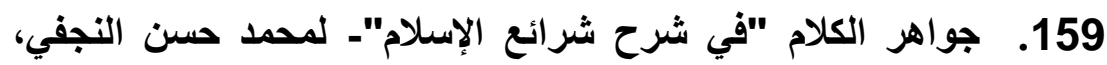

حققه: عباس القوجاني، ط: الأولى، خورشيد الإسلام دار الكتب الإسلامية ـ

طهران، 1367 هـ.

160. الحدائق الناضرة في أحكام العترة الطاهرة- ليوسف البحراني، قام

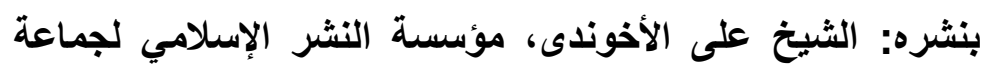

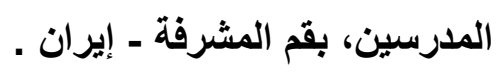

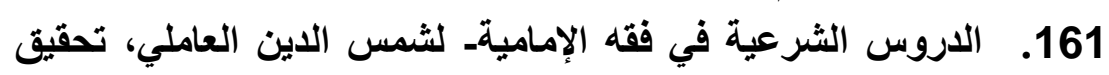

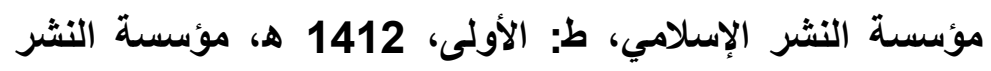
الإسلامي التابعة لجماعة المدرسين بقم المشرفة.

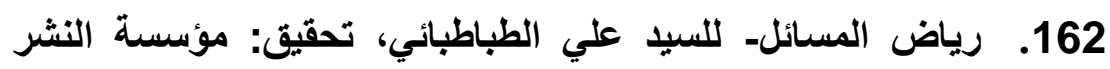
الإسلامي التابعة لجماعة المدرسين بقم المشرفئ.

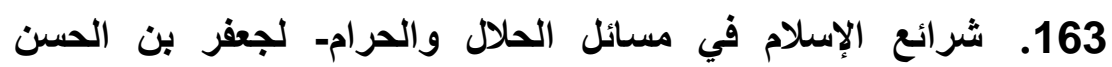

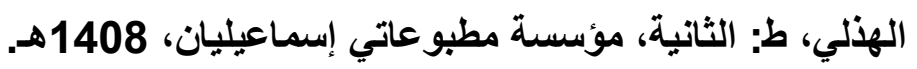




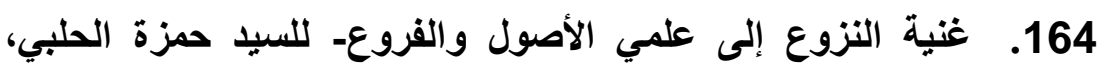

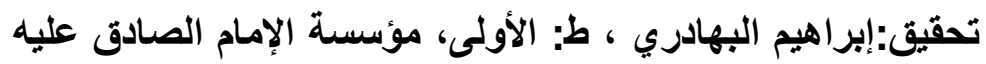

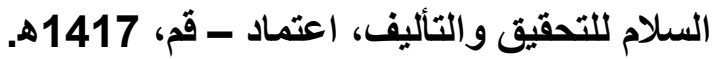

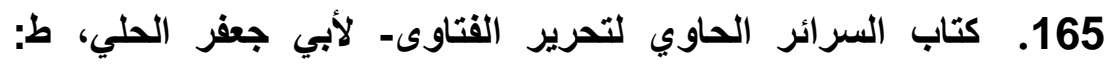

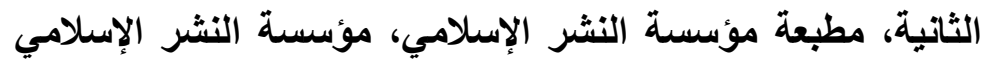

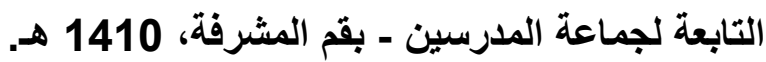

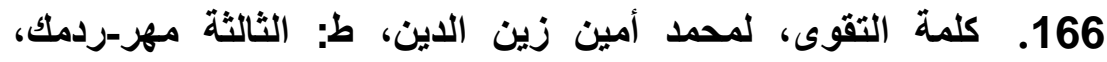
1413 هـ.

167. مختلف الثيعة في أحكام الثريعة. لأبي منصور الحسن الأسدي،

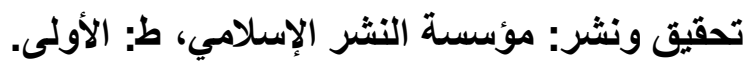

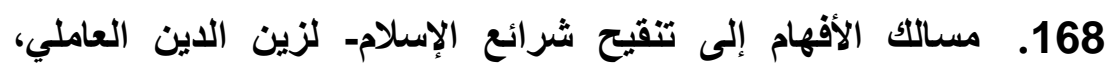

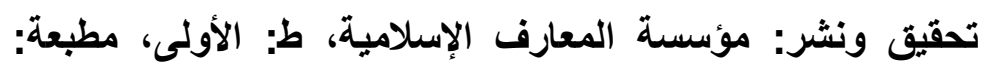

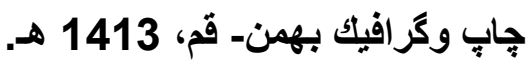

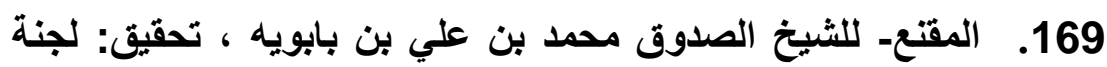

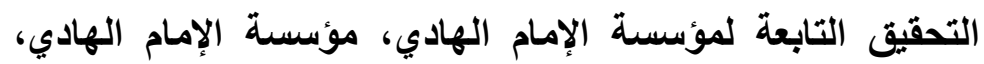
المطبعة: اعتماد، 1415 هـ 170. الينابيع الفقهية علي أصغر مرواريد، ط:الأولى، دار التراث،

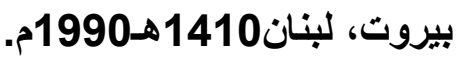
الفقه الإباضي:

171. شرح النيل وشفاء العليل - لضياء الدين عبدالعزيز التميمي،

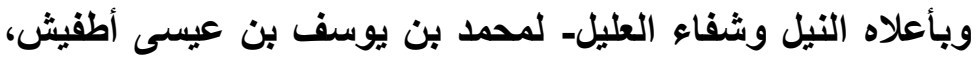

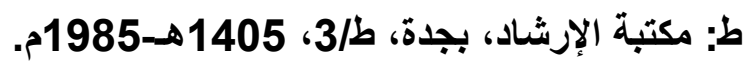

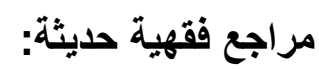

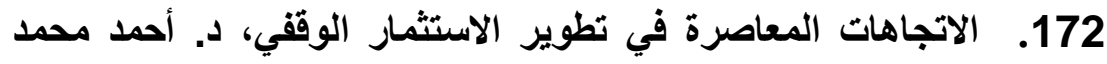

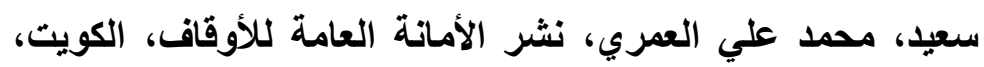

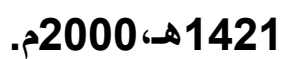

173. أحكام تكوين المخصصات في البنوك الإسلامية وأثرها على توزيع

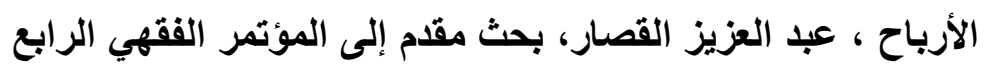

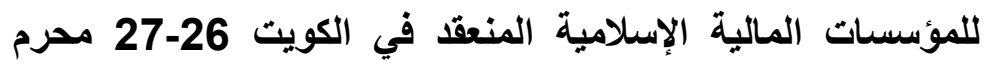
1433هـ، الموافق 22-21 ديسمبر 2011م. 
174. إحياء الأوقاف الخيرية، د. معبد الجارحي، بحث مقدم للمؤتمر الثاني للأوقاف بالمملكة العربية السعودية.

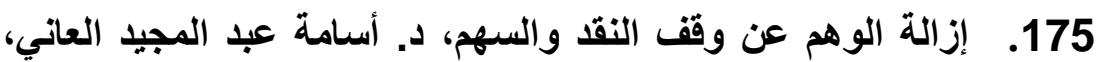

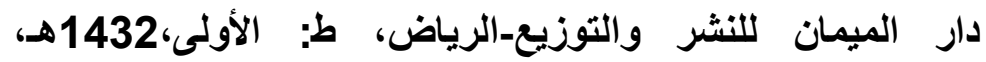

2011

176. الاستثمار المعاصر للوقف، الأستاذ الاكتور محمد الزحيلي، دار

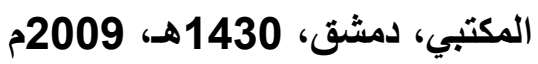
177. استثمار أموال الوقف، د. حسين شحاتة ، بحث منشور ضمن

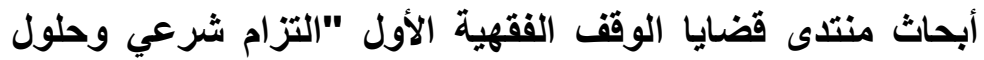

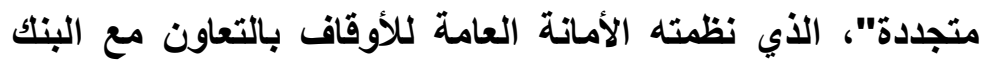

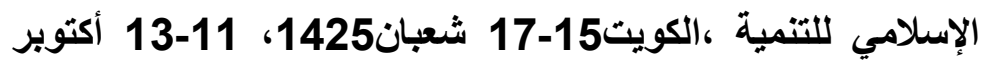

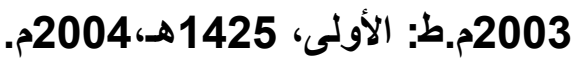

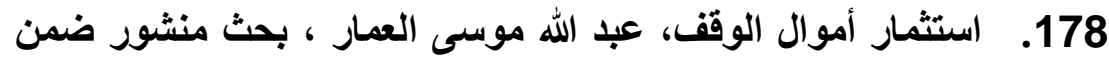

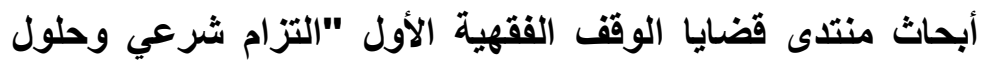

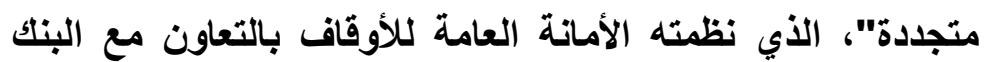

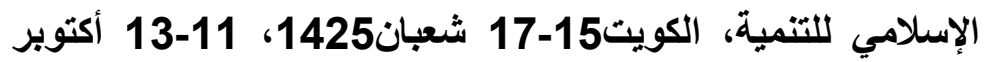

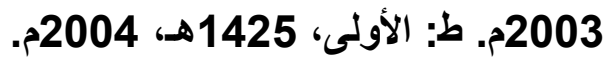
179. الاستثمار في الوقف وفي غلاته وريعه، د. محمد عبد الحليم عمر،

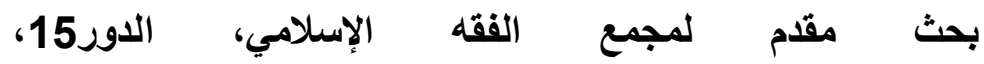

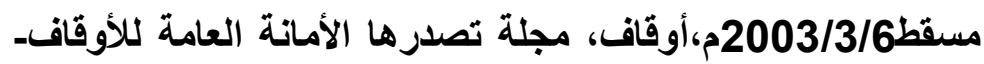
الكويت ، العدد( 15) 1425، 2003/3 2004م.

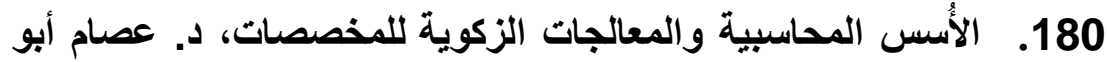

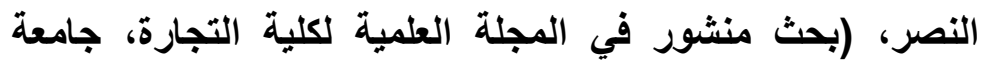

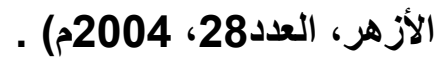

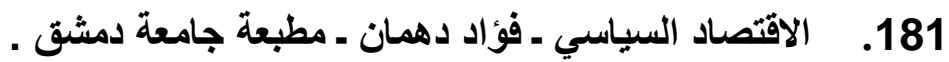

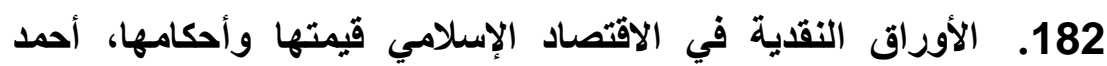
حسن، دار الفكر، دمشق،ط2002. 183. الأوراق النقدية في الاقتصاد الإسلامي، قيمتها وأحكامها، للأستاذ

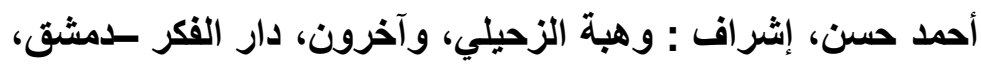


184. الأوقاف فقها واقتصادا ، د. رفيق يونس المصري دار المكتبي ط

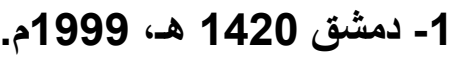

185. أوهام وحقائق حول الأزمة النقاية، غيوم كندي، ترجمة: هثام

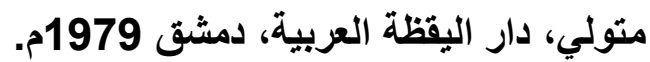

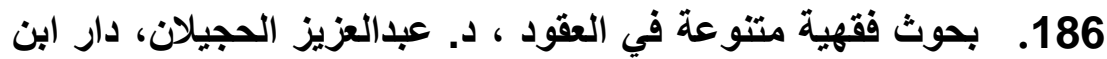
الجوزي، الرياض، القاهرة، ط: الأولى، 1427 هـ.

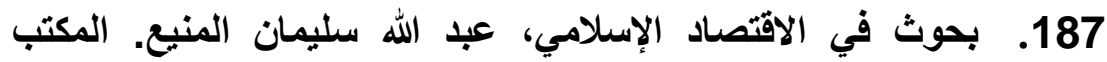
الإسلامي بيروت الطبعة الأولي في الأهي، 1416 هـ

188. تاريخ النقود، فيكتور مورجان، ترجمة: نور الاين خليل، الهيئة

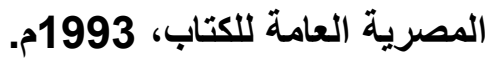

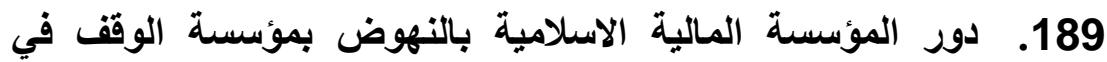

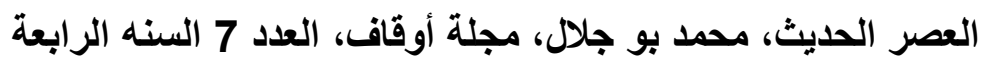

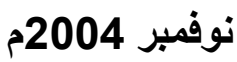

190. رسالة في الفقه الميسر، أ. د صالح بن غانم السدلان، وزارة

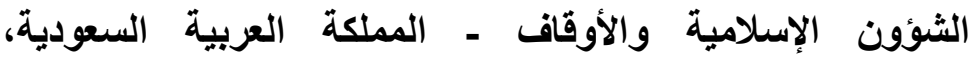

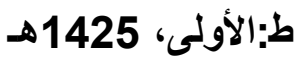
191. رسالة في جواز وقف النقود لأبي السعود العمادي الحنفي ، ط:

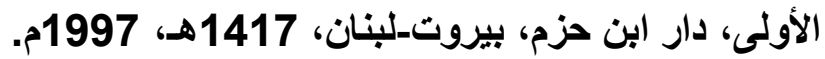

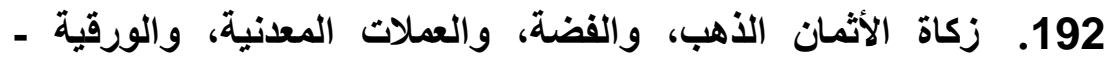

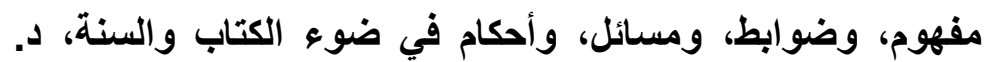

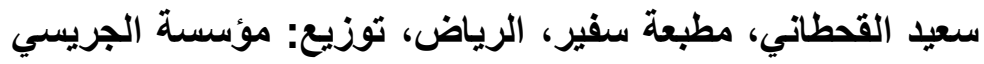

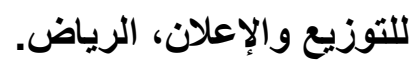

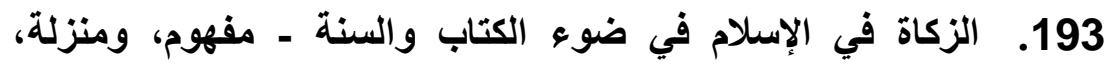

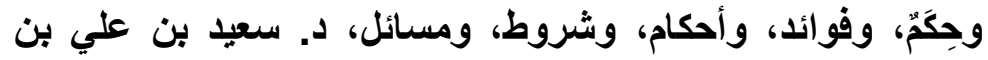

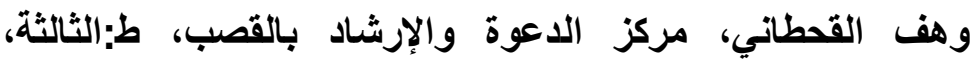

$$
1431 \text { هـ - } 2010 \text { م. }
$$

194. صناديق الوقف الاستثماري، دراسة فقهية- اقتصادية، رسالة

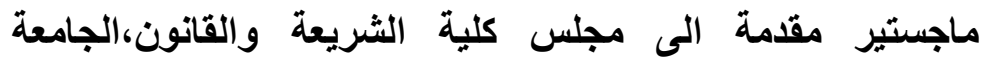
الاسلامية- بغداد، أسامة عبد المجيد عبد الحميد العاني، 1429 هـ 


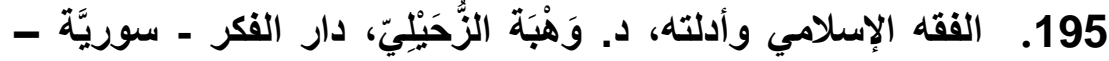

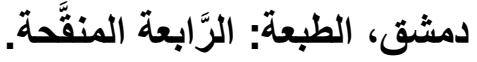

196. قضايا فقهية معاصرة في الأوقاف الإسلامية، منذر قحف، دارئ، دار الفكر

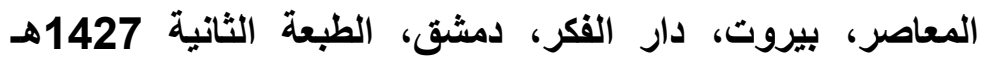
2006

197. القوانين المصرية المختارة من الفقه الإسلامي، محمد أحمد فرج

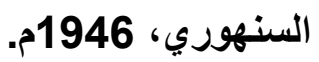

198. المؤسسة الوقفية المعاصرة تأصيل وتطوير، إعداد: د. عبدالسلام العبادي. منشور بمجلة مجمع الفقه الإسلامي ، العيلة العدد 13 1422، هـ، 2001م.

199. مجلة البحوث الإسلامية ـ مجلة دورية تصدر عن الرئاسة العامة لإدارات البحوث العلمية والإفتاء والدعوة والإرشاد. 200. مجلة مجمع الفقه الاسلامي، الدورة الخامسة عشر بمسقط (سلطنة

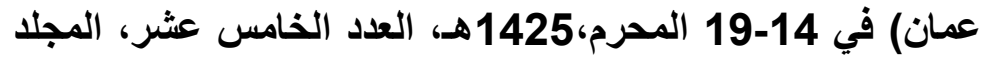

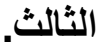
201. المحاسبة المالية، عبدالباسط رضوان وآخرون، مؤسسة دار

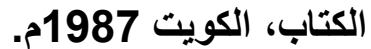

202. المخصصات والاحتياطات في البنوك الإسلامية من منظور فقهي،

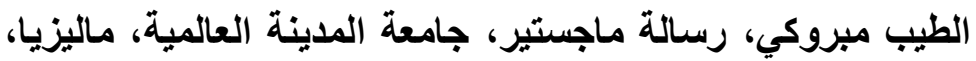

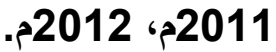

203. مشروع قانون الوقف الكويتي في إطار استثمار وتنمية الموارد

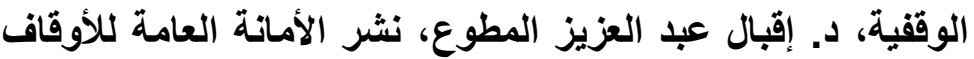
بدولة الكويت، 1421 هـ 2001م. 204. المصارف الأسلامية ضرورة حتمية، محمود محمد بابلي، ط: بلأ الأولى، المكتب الإسلامي بيروت، 1989م.

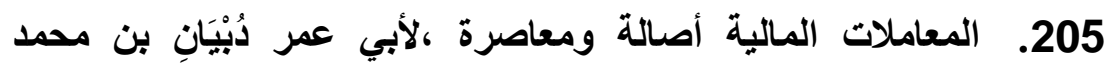

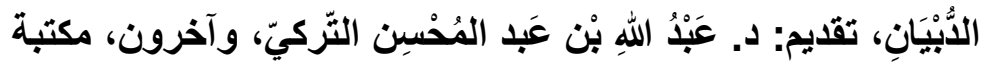

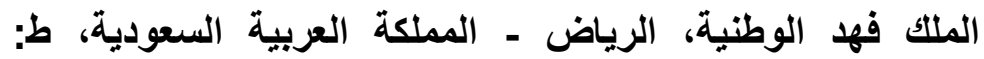


206. المعاملات المالية المعاصرة في الفقه الإسلامي، د. محمد عثمان

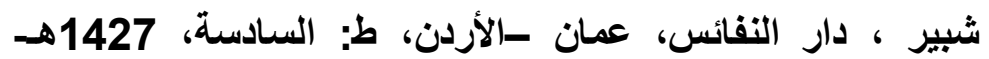
2007م

207. مقدمة في الاقتصاد، محمد الليثي، محمد إسماعيل، دار الجامعات

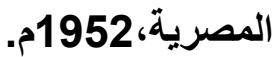

208. مقدمة في النقود والبنوك للاكتور محمَّد زكي شافعي، دار النهضة

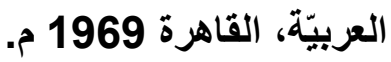
209. من فقه الوقف، د. أحمد عبد العزيز الحداد، ط: الأولى، دائرة

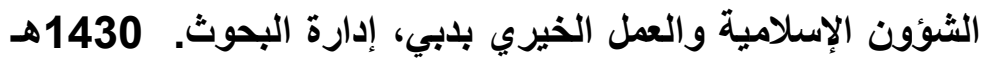
2009 -

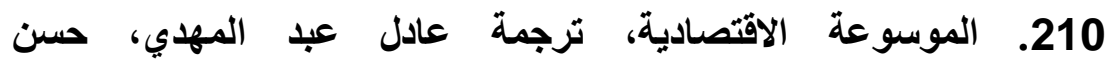

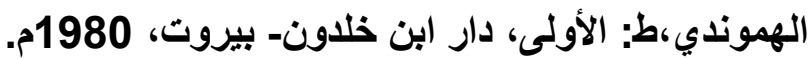
موسوعة الفقه الإسلامي، محمد بن إبراهيم بن عبد الله التويجري، .211

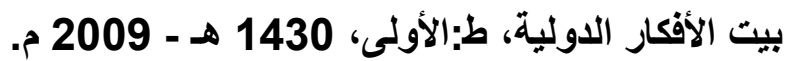
212. نظام الوقف في التطبيق المعاصر، محمود مهدي، 1423هـ لألهـ 2002 نظام وقف النقود ودوره في تنمية المرافت التربوية والتعليمية، د. .213 محمد ليبا، د. محمد إبراهيم نقاسي، الجامعة الإسلامية العالمية ودية

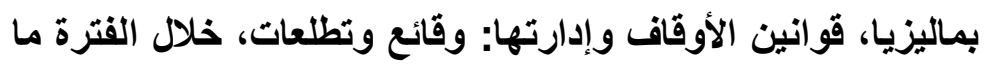

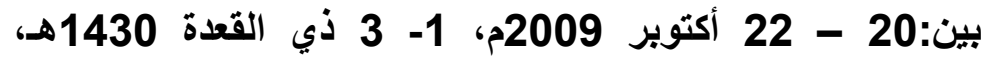

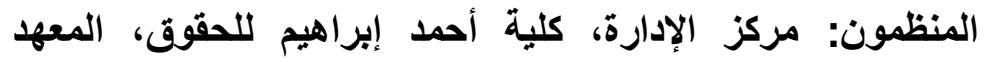

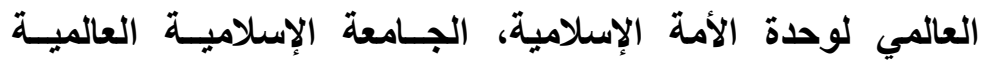

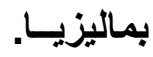
214. النقود الائتمانية، إبراهيم صالح العمر ، ط: الأولى 1414هـ، دار

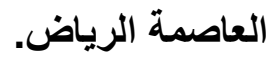

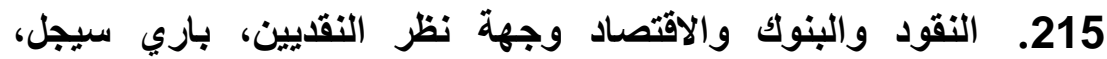

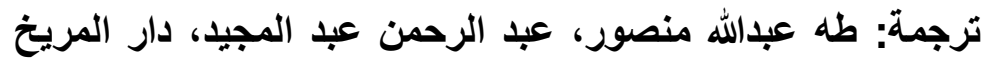
الرياض، 1987م. 216. النقود والبنوك، عبدالمنعم المبارك، وأحمد الناقة، مركز الإسكندرية للكتاب، الإسكندرية، مصر، ولإنو، 1995م. 
النقود والتوازن الاقتصادي، سهير حسن، مؤسسة شباب الجامعة،

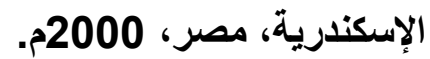

218. النقود والسياسة النقدية في الاقتصاد اليمني العديث، عبد العزيز

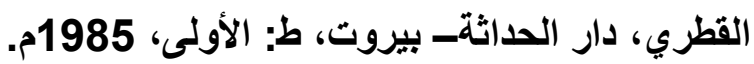

219. النقود والمصارف، كمال شرف، هشام عراج، نشر: جامعة دمشث،

1994 م. 1994

220. النوازل الوققية، د. ناصر عبدالله الميمان ، دار ابن الجوزي،

1430هـ. 1 140

221. وسائل تنمية أموال الأوقاف وزيادة مواردها، خميس أحمد

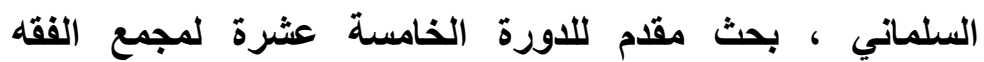

الإسلامي، مسقط، 2004/3/6م.

222. الوصايا والأوقاف في الفقه الإسلامي- وهبة الزحيلي، دار الفكر،

دمشث، ط: الأولى، 1987م. 1987.

223. الوقف الإسلامي، تطوّره، إدارته، تنميته: منذر قحف، دار الفكر

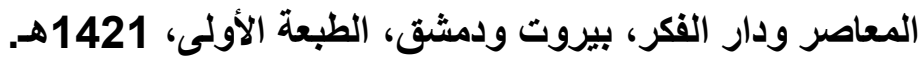

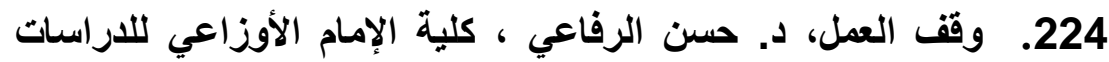

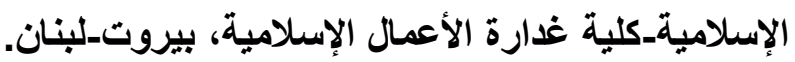

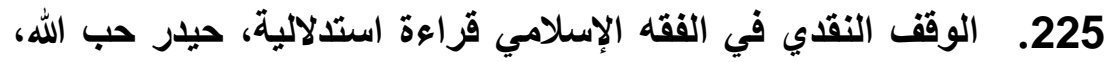

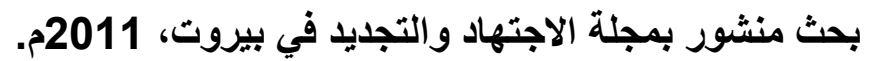

226. الوقف النقدي مدخل لتفعيل دور الوقف في حياتنا المعاصرة ، د. د.

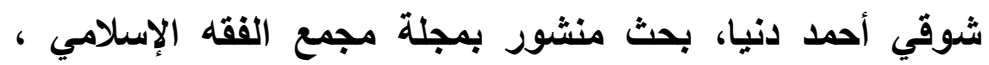

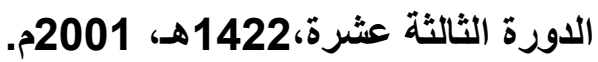

227. وقف النقدين، د. عبد الله بن موسى العمار، بحث منشور بمجلة البحوث الفقهية المعاصرة، العدد الثاني.

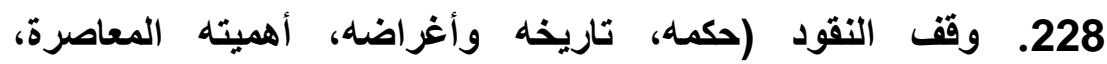

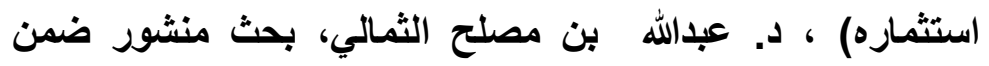

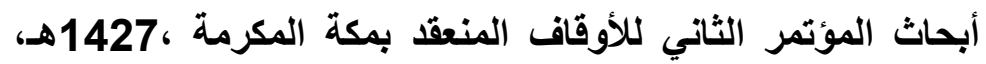
2006 229. وقف النقود واستثمارها د. محمد نبيل غنايم، بحث منشور ضمن

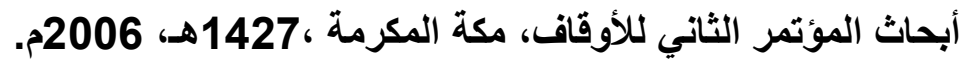


230. وقف النقود واستثمارها، د. محمد الملا بحث منشور ضمن أبحاث

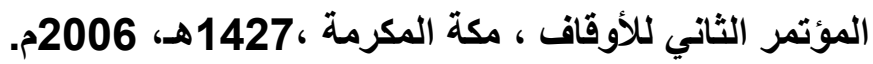

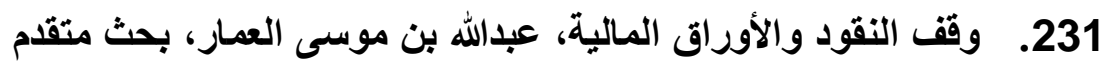
الى اعمال منتدى قضايا الوقف الفقهية الثاني (تحديات عصرية

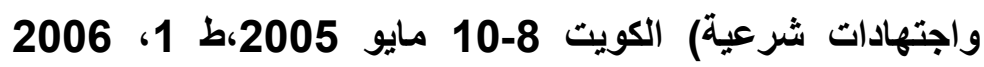
،الكويت .

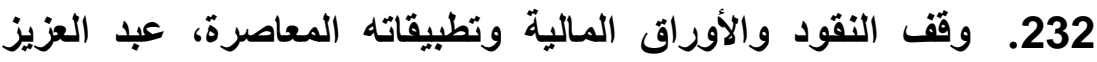

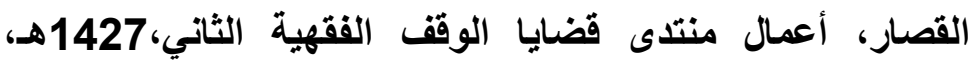
2006.

233. الوقف ودوره في التنمية الاجتماعية، د. سليم هاني منصور، بحث

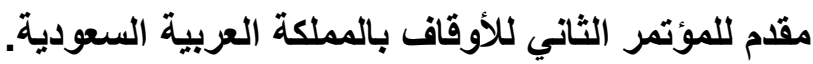

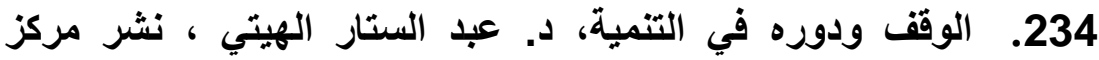

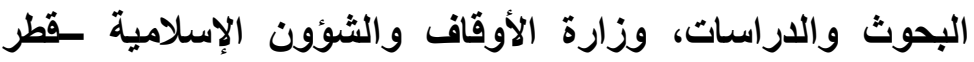
1419هـ، 1998م. اللغة والمعاجم والغريب:

235. أنيس الفقهاء في تعريفات الألفاظ المتداولة بين الفقهاء، قاسم بن

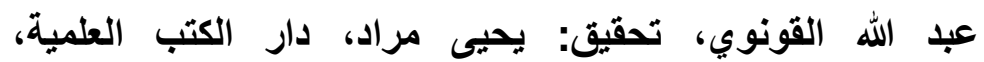
ط:2004م-1424هـ.

236. تاج العروس من جواهر القاموس، محمّد بن محمّل الحسيني، الملقبّ بمرتضى، الزَّبيدي، تحقيق: مجموعة من المحققين، دار الهـاية.

237. تحرير ألفاظ التببيه، لأبي زكريا يحيى بن شرف النووي، تحقيق:

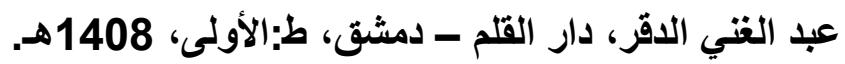

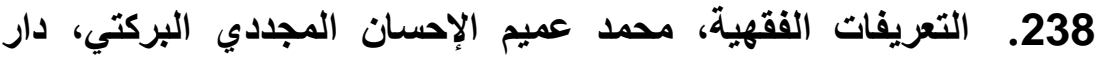

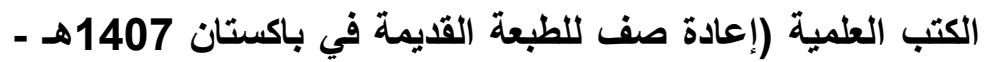
1986م)، ط:الأولى، 1424 (إعادة هـ - 2003م. 239. تهذيب اللغة، محمد بن أحمد بن الأزهري الهروي، تحقيق: محمد

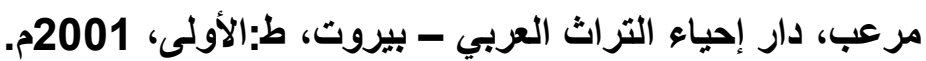


240. التوقيف على مهمات التعاريف، زين الدين محمد المدعو بعبد

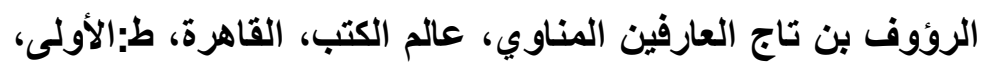
1410هـ-1990م. 241. لية الفقهاء، أحمد بن فارس القزويني، تحقيق: د. عبد الله

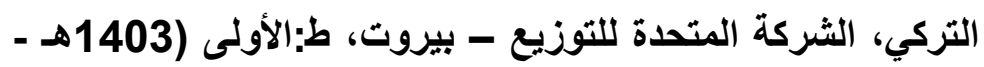

1983

242. دستور العلماء = جامع العلوم في اصطلاحات الفنون، القاضي عبد

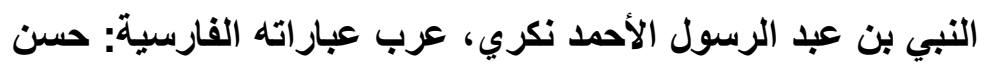

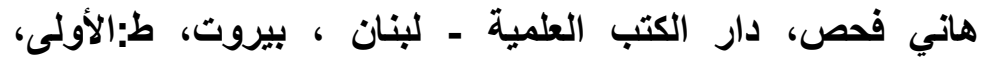

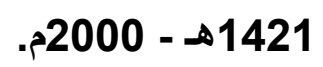

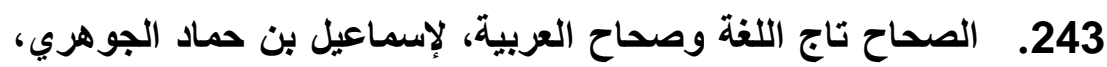

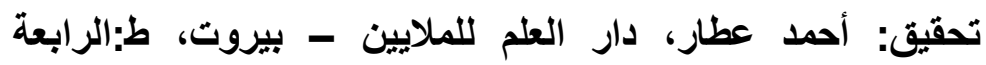

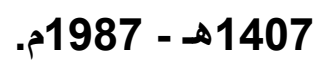

244. طلبة الطلبة، عمر بن محمد بن أحمد، نجم الدين النسفي، المطبعة

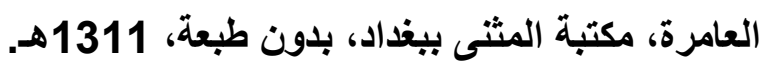

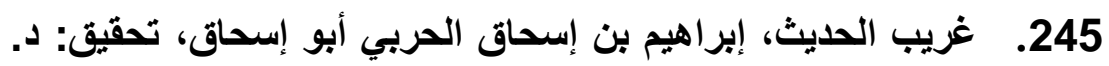

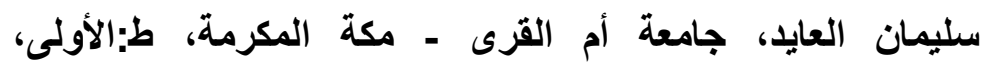
1405هـ.

246. القاموس الفقهي لغة واصطلاحا، الدكتور سعدي أبو حبيب، دار

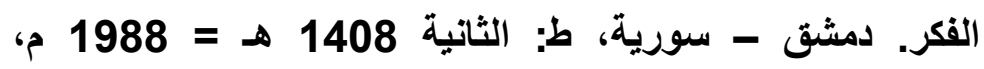
تصوير: 1993 م. 247. كتاب العين، الخليل بن أحمد الفراهيدي، تحقيق: د مهدي المخزومي، د إبراهيم السامرائي، دار ومكتبة الهلال.

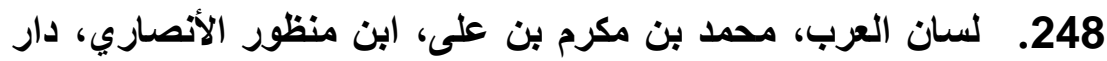

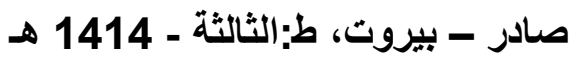

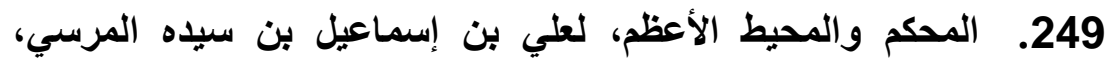

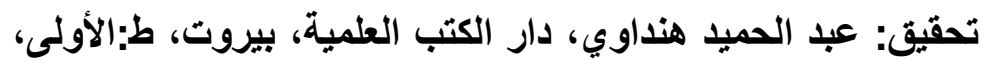

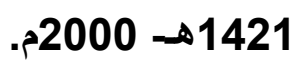




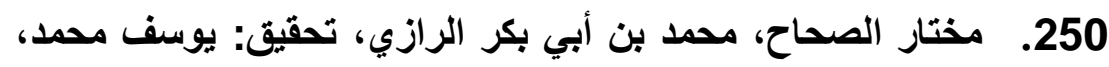

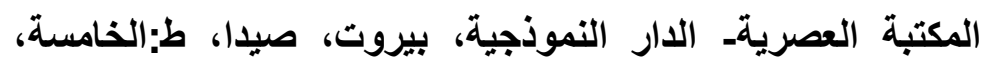
1420هـ 1999م.

251. المصباح المنير في غريب الثرح الكبير، أحمد بن محمد بن علي

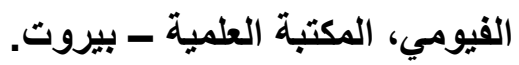

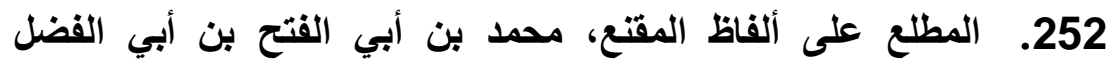

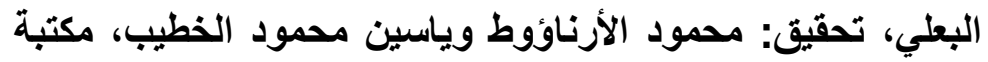

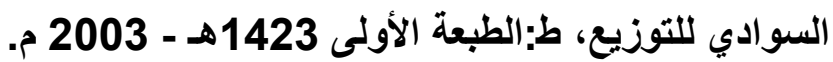

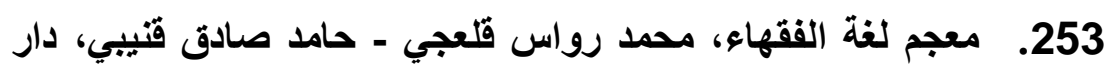

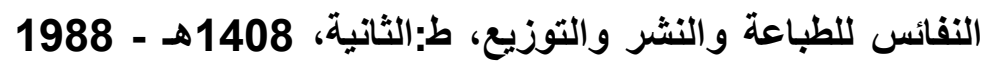
254. معم مقاييس اللغة، أحمد بن فارس بن زكرياء القزويني،

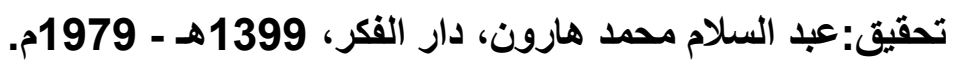

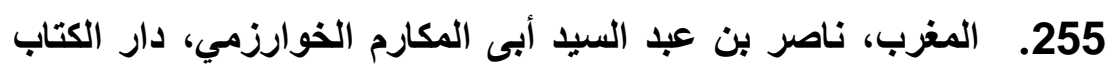

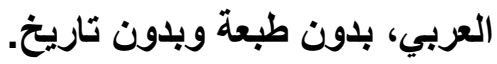

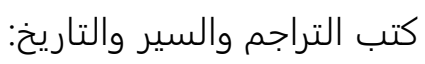

256. تاريخ الإسلام ووفيات المشاهير والأعلام، شمس الدين محمد بن النائ أحمد قَائماز الذهبي، المكتبة التوفية التوفيقية.

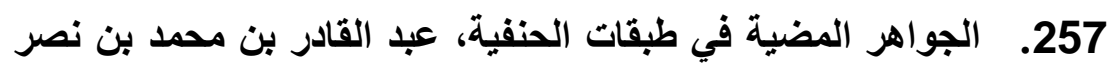
الله القرشي، مير محمد كتب خانه ــ كراتثي.

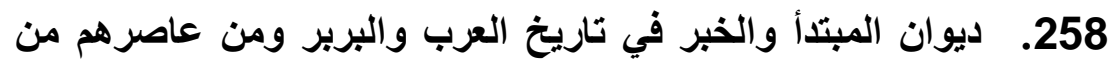

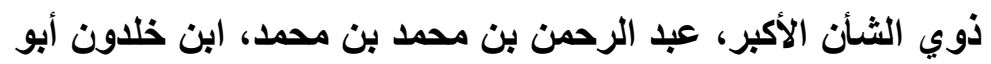

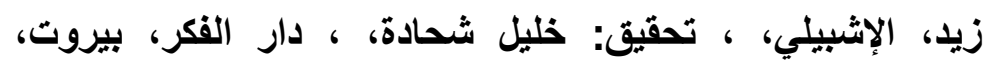

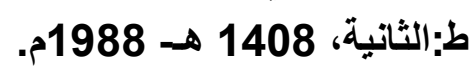

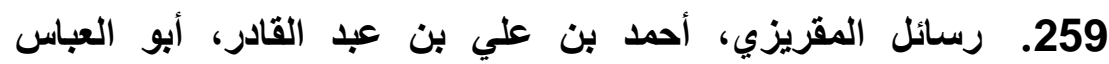

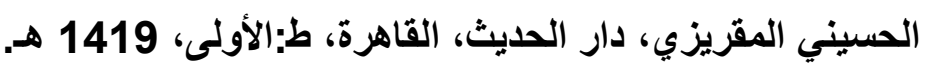
260. فتوح البلدان، أحمد بن يحيى بن جابر البَلاذُري، دار ومكتبة الهلالبيروت، عام النشر: 


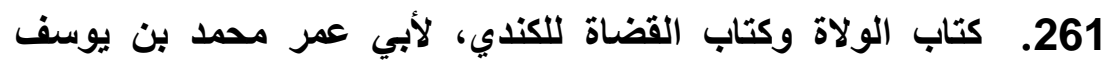

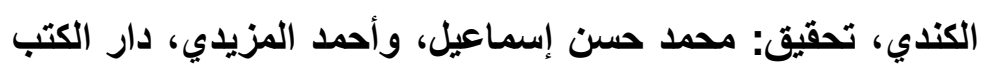

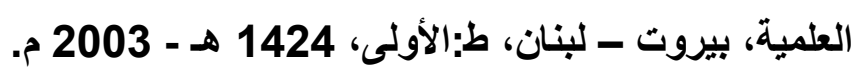

262. المؤتلف والمختلف في أسماء الثعراء وكناهم وألقابهم وأنسابهم

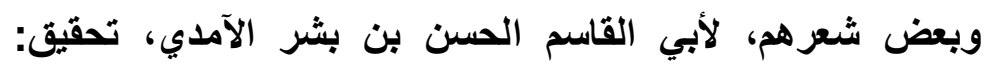
الأستاذ الاكتور ف. كرنكو، دار الجيل، بيروت، ط:الأولى، 1411

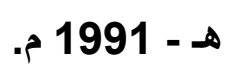

مواقع الإنترنت:

263. الموسوعةالحرة:

https://ar.wikipedia.org/wiki

$* * * * *$ 